Universidade de São Paulo

Instituto de Biociências - Departamento de Botânica

Marisa Moura Momoli

\title{
Aspectos funcionais do gene thi1 em plantas selvagens e mutantes de Arabidopsis thaliana (Brassicaceae)
}

São Paulo

- $2008-$ 
Universidade de São Paulo

Instituto de Biociências - Departamento de Botânica

\section{Aspectos funcionais do gene thi1 em plantas selvagens e mutantes de Arabidopsis thaliana (Brassicaceae)}

Tese apresentada ao Instituto de Biociências da Universidade de São Paulo como parte dos requisitos para a obtenção do título de Doutor em Ciências na área de Botânica

Orientadora: Prof. Dr ${ }^{\mathrm{a}}$ Marie-Anne Van Sluys

São Paulo

- 2008 - 
FICHA CATALOGRÁFICA ELABORADA PELA BIBLIOTECA DO INSTITUTO DE BIOCIÊNCIAS/USP

Momoli, Marisa Moura

M 732a Aspectos funcionais do gene thi1 em plantas selvagens e mutantes de Arabidopsis thaliana (Brassicaceae) /

Marisa Moura Momoli. -- São Paulo : M. M. M., 2008

139p. : il.

Tese (Doutorado) - Instituto de Biociências da Universidade de São Paulo. Departamento de Botânica, 2008 .

1. Arabidopsis thaliana 2. Antioxidantes

3. th11 4. Tiamina 5. Reparo de DNA

I.Universidade de São Paulo. Instituto de Biociências.

Departamento de Botânica. II. Título.

LC QK 495.C9 
Dedico esta tese à meus pais, avós e irmãos, por apoiarem meus estudos e sempre entenderem minhas decisões, e ao meu marido pelo incentivo e compreensão. 
"Viver,

e não ter a vergonha de ser feliz,

Cantar e cantar e cantar

A beleza de ser um eterno aprendiz..."

"O que é, o que é"

Gonzaguinha 


\section{AGRADECIMENTOS}

À Prof. Marie-Anne Van Sluys por aceitar me orientar, pela confiança e, principalmente, por conseguir entender alguém tão cabeça-dura. À Prof. Magdalena Rossi, por contribuir de maneira efetiva nas discussões de laboratório

À FAPESP (processo $n^{\circ}$ 05/56276-8) e à CAPES pelo apoio financeiro essencial para a realização desse trabalho

Ao Prof. Carlos Menck pelas discussões científicas e a todos os seus alunos por serem sempre muito simpáticos quando eu pedia ECL emprestado ou o aparelho para fazer slot blot.

Ao Prof. Márcio de Castro pelas discussões científicas, em especial nos congressos

À Adriana Rios Lopes por minha iniciação científica. A bioquímica aprendida permitiu a realização desse trabalho e, certamente, será de fundamental importância para o resto de minha vida

À Priscila Kashiwabara por me iniciar no mundo das plantas

À Leonor (Léo). Esta realmente merece uma homenagem especial. Quantos galhos a Léo quebra para todo mundo... À Ana Maria, por momentos de descontração enquanto eu esperava autoclavar algum material.

A todos os colegas do GaTE lab: Alessandro, Ana Paula, Andrés, Breno, Bruno, Claudinha, Daí (de passagem), Danizinha, Dani Milstein, Douglas, Edgar, Érika, Fabiane, Guilherme, Hana, Jonas, Juliana, Juliane, Luisa, Marcelo, Maria Elisa, Mayra, Myna, Nathalia (já faz parte do lab), Nilo, Regininha, Robson, Silvia e Vivi. O mesmo aos colegas do laboratório de fisiologia vegetal.

A amigos do coração, meio irmãos (em ordem alfabética para não gerar ciúmes): Ana Faustinoni, Ana Maria Fraga, Carla Laforgia, Faby Marangon, José Barufi, Melissa Schleich, Percila Barros, Raquel Stabellini, Ricardo Furia, Roberta Masiero, Sandra Motikawa e Tiago Falótico. Amo muito vocês!!!

À minha mãe, meu pai e aos meus irmãos por sempre incentivarem meus estudos e me apoiarem quando necessário. À Tata, por me fazer gostar de estudar e pela descoberta da música de boa qualidade. À Miriam por me servir de exemplo para as coisas da vida. Aos meus amores Carol e Mateus. Esses dois me matam de felicidade!!!

Aos meus avós Diva e Paulo, por me mostrarem o que é certo e o que é errado. E ao vô por tantos computadores consertados. Sem ele teria sido mais difícil sair esta tese. Lá estava ele para me ajudar quando todos os computadores pifavam juntos!!!

Ao Fernando: “...Orfeu menos Eurídice... / Coisa incompreensível! A existência / Sem ti é como olhar para um relógio / Só com o ponteiro dos minutos. Tu / És a hora, és o que dá sentido / E direção ao tempo...”. Obrigada pela compreensão, pela paciência e, também, pelas discussões científicas 


\section{Aos Colaboradores:}

Antioxidantes:

Ao Prof. Luis Eduardo Soares Netto pela disponibilização de reagentes para a realização da quantificação de enzimas antioxidantes

Aos Profs. Walter Terra e Clélia Ferreira por cederem tão desinteressadamente seu laboratório para a utilização do Spectra Max (espectrofotômetro de placa) e aos seus alunos que sempre me receberam tão bem

À Thais Semprebom pelo apoio prático e psicológico na quantificação de antioxidantes não-enzimáticos e peróxido de hidrogênio

Carboidratos de baixo peso molecular:

Ao Marco Tiné e ao Prof. Marcos Buckeridge pela colaboração na quantificação de carboidratos de baixo peso molecular

Quantificação de tiamina:

À Graziella Ronsein e ao Prof. Paolo di Mascio pela insistência na quantificação de tiaminas

Quantificação de danos no DNA:

To Prof. Bennett Van Houten and his group to the collaboration in DNA damage quantification and to receive me so sweetly in the USA. A special thanks to Hong and Marcelo Bonini who helped me so much there.

Ao Prof. Bennett Van Houten e sua equipe pela colaboração na quantificação de danos e por me receberem tão prontamente e me acolherem tão bem nos EUA. Agradecimento especial à Hong e ao Marcelo Bonini, que me ajudaram por lá.

Proteômica:

Ao Breno Lourenzzo pelas aulas de proteômica e por estar sempre pronto para fazer experimentos. Fica bastante fácil colaborar com pessoas assim. Ao Dr. Jonas Perales e ao André Ferreira, da Fiocruz, por fazerem o seqüenciamento das proteínas de interesse. 


\section{Índice}

1. INTRODUCC̃̃O _

1.1. TIAMINA (VITAMINA $B_{1}$ ) 16

1.2. ESPÉCIES ATIVAS DE OXIGÊNIO __ 18

1.3. REPARO DE DNA

1.4. GENE THI1 __ 30

2. OBJETIVOS

3. MATERIAL E MÉTODOS __ 36

3.1. Cultivo das Plantas _ 36

3.1.1. Material botânico — 36

3.1.1.1. Condições utilizadas _ 36

3.1.2. Solução nutritiva e meios de cultura __ 37

3.1.2.1. Solução nutritiva

3.1.2.2. Meio de cultura___ 38

3.2. MOdULAÇ̃̃o dA EXPRESSÃO dO GENE THI1 EM A. THALIANA___ 38

3.2.1. Análise do promotor thi1__ 38

3.2.1.1. Tratamento das plantas__ 38

3.2.1.2. Preparação do material _ 39

3.2.1.3. Análise das plantas_— 40

3.2.2. Análise transcricional___ 40

3.2.2.1. Condições experimentais___ 40

3.2.2.1.1. Comparação de expressão de RNAm thi1 entre as linhagens selvagem, mutante e transgênicas

3.2.2.1.2. Análise de expressão de RNAm thi1 ao longo do dia 40

3.2.2.1.3. Análise da expressão de RNAm thi1 em plantas crescidas na ausência de sacarose ou sob

hipoxia $\quad 41$

3.2.2.2. Extração do RNA total __ 41

3.2.2.3. Preparação do RNA_— 42

3.2.2.4. Iniciadores utilizados__ 43

3.2.2.5. Condições utilizadas na RT-qPCR __ 43

3.2.2.6. Análise dos resultados _ـ 44

3.2.3. Análise traducional___ 44

3.2.3.1. Condições experimentais___ 44

3.2.3.1.1. Comparação dos níveis da proteína THI1 entre as linhagens selvagem, mutante e transgênicas

3.2.3.1.2. Análise dos níveis da proteína THI1 ao longo do dia 44

3.2.3.1. Extração de proteínas _— 45

3.3. ASPECTOS BIOQUÍMICOS E FISIOLÓGICOS ASSOCIADOS AO GENE THI1_ 46

3.3.1. Taxa de germinação de sementes ___ 46

3.3.2. Massa fresca __ 47

3.3.3. Carboidratos de baixo peso molecular ___ 47

3.3.3.1. Extração de carboidratos de baixo peso molecular __ 47

3.3.3.2. Condições cromatográficas _ـ 48

3.3.4. Antioxidantes__ 48

3.3.4.1. Enzimas antioxidantes__ 49

3.3.4.1.1. Tratamento das plantas__ 49

3.3.4.1.1.1. Claro / Escuro $\longrightarrow 49$

3.3.4.1.1.2. Alagamento $\longrightarrow 49$

3.3.4.1.1.3. Crescimento em meio sem sacarose $\quad 50$

3.3.4.1.2. Extração de enzimas antioxidantes —

3.3.4.1.3. Ensaios de Superóxido Dismutase (SOD) ___ 51

3.3.4.1.4. Ensaios de catalase (CAT)

3.3.4.1.5. Ensaios de ascorbato peroxidase (APX) __ 54

3.3.4.1.6. Ensaios de glutationa peroxidase (GPX) $\longrightarrow 55$

3.3.4.2. Antioxidantes não-enzimáticos___

3.3.4.2.1. Tratamento das plantas $\quad 57$

3.3.4.2.2. Extração de ASC e GSH _

3.3.4.2.3. Determinação de ASC e GSH por HPLC __ 57

3.3.5. Espécies ativas de oxigênio___ 58

3.3.5.1. Deteç̧ão de $\mathrm{H}_{2} \mathrm{O}_{2} \longrightarrow 58$

3.3.6. Perfil protéico _—59

3.3.6.1. Extração das proteínas de A. thaliana __ 59 
3.3.6.2. SDS-PAGE e eletroforese bidimensional 60

3.3.6.3. Visualização das proteínas, análise de imagem e quantificação

3.3.6.4. Identificação dos spots com expressão diferencial

3.3.7. Quantificação de danos no DNA

3.3.7.1. Tratamento das plantas

3.3.7.1.1. $\mathrm{H}_{2} \mathrm{O}_{2}$

3.3.7.2. Extração do DNA total

3.3.7.3. Iniciadores utilizados

3.3.7.4. Condições utilizadas nas PCRs

3.3.7. Tiamina

3.3.7.1. Extração de tiamina

3.3.7.2. Condições cromatográficas 68

3.3.8. Análises estatísticas___ 69

4. RESULTADOS __ 71

4.1. MOdULAÇÃO DA EXPRESSÃO DO GENE THI1 EM A. THALIANA

4.1.1. Análise transcricional___ 71

4.1.2. Análise traducional___ 75

4.2. ASPECTOS BIOQUÍMICOS E FISIOLÓGICOS ASSOCIADOS AO GENE THI1 77

4.2.1. Taxa de germinação de sementes ___ 77

4.2.2. Massa fresca __ 78

4.2.3. Carboidratos de baixo peso molecular __ 79

4.2.4. Antioxidantes__ 80

4.2.5. Perfil protéico _ 85

4.2.6. Quantificação de danos no DNA ___ 89

4.2.7. Tiamina _ 93

5. DISCUSSÃO

5.1. MODULAÇÃO DA EXPRESSÃO DO GENE THI1 EM A. THALIANA__

5.2. ASPECTOS BIOQUÍMICOS E FISIOLÓGICOS ASSOCIADOS AO GENE THI1_ 100

6. MODELO

7. CONCLUSÕES

8. REFERÊNCIAS BIBLIOGRÁFICAS 125 


\begin{tabular}{|c|c|c|}
\hline Figura & Descrição & Página \\
\hline Figura 1 & Rota final da via biossintética da tiamina em E. coli. & 17 \\
\hline Figura 2 & $\begin{array}{l}\text { Esquema simplificado das vias metabólicas em que a TPP } \\
\text { participa como cofator. }\end{array}$ & 18 \\
\hline Figura 3 & Formação de ROS durante a redução de oxigênio à água. & 19 \\
\hline Figura 4 & Produção de ROS nos cloroplastos e peroxissomos. & 20 \\
\hline Figura 5 & $\begin{array}{l}\text { Danos no DNA por desaminação das bases, perda de bases, } \\
\text { formação de dímeros de pirimidina e alquilação de bases. }\end{array}$ & 24 \\
\hline Figura 6 & Reparo de DNA por fotorreativação. & 26 \\
\hline Figura 7 & Reparo de DNA por excisão de bases e de nucleotídeos. & 27 \\
\hline Figura 8 & Reparo do DNA por recombinação. & 29 \\
\hline Figura 9 & $\begin{array}{l}\text { Análise comparativa de fenótipos entre plantas da linhagem } \\
\text { selvagem e mutante de Arabidopsis thaliana crescendo em meio } \\
\text { suplementado ou não com tiamina. }\end{array}$ & 31 \\
\hline Figura 10 & Direcionamento de THI1 para cloroplastos e mitocôndrias & 32 \\
\hline Figura 11 & $\begin{array}{l}\text { Estrutura octamérica de THI1 e detalhe do precursor do tiazol co- } \\
\text { purificado com a proteína THI1. }\end{array}$ & 33 \\
\hline Figura 12 & Apresentação esquemática do ensaio de superóxido dismutase. & 52 \\
\hline Figura 13 & Apresentação da reação catalisada pela catalase. & 53 \\
\hline Figura 14 & Apresentação da reação catalisada pela ascorbato peroxidase. & 54 \\
\hline Figura 15 & Apresentação da reação catalisada pela glutationa peroxidase. & 55 \\
\hline Figura 16 & Passos necessários para realizar o ensaio de QPCR & 63 \\
\hline Figura 17 & $\begin{array}{l}\text { Expressão relativa de mRNA thi } 1 \text { utilizando-se linhagens de } A \text {. } \\
\text { thaliana selvagem (Ler), mutante (tz-201), thi } 1_{s} a \text { e thi } 1_{a s} a \text {. }\end{array}$ & 71 \\
\hline Figura 18 & $\begin{array}{l}\text { Expressão de RNAm thi1 por RT-qPCR e análise histoquímica de } \\
\text { plantas de } A \text {. thaliana coletadas em diferentes horários }\end{array}$ & 72 \\
\hline Figura 19 & $\begin{array}{l}\text { Ritmo circadiano. Expressão relativa de mRNA thi1 utilizando-se } \\
\text { plantas selvagem (Ler) de } A \text {. thaliana. }\end{array}$ & 73 \\
\hline Figura 20 & $\begin{array}{l}\text { Análise quantitativa da proteína THI1 em extratos das linhagens } \\
\text { selvagem (Ler), mutante (tz-201), senso (thi1s a) e antisenso } \\
\text { (thiasa). }\end{array}$ & 75 \\
\hline Figura 21 & $\begin{array}{l}\text { Análise quantitativa da proteína THI1 feita com extratos da } \\
\text { linhagem selvagem (Ler) de } A \text {. thaliana coletadas em diferentes } \\
\text { horários. }\end{array}$ & 75 \\
\hline Figura 22 & $\begin{array}{l}\text { Taxa de germinação de sementes das linhagens selvagem (Ler), } \\
\text { mutante (tz-201), thi } 1_{s} a \text { (senso) e thi } 1_{a s} a \text { (antisenso) de } \\
\text { Arabidopsis thaliana estocadas por } 3,6 \text { e } 9 \text { meses, ou não } \\
\text { estocadas }(0) \text {. }\end{array}$ & 76 \\
\hline Figura 23 & $\begin{array}{l}\text { Determinação de massa fresca de planta inteira, parte aérea e raiz } \\
\text { das linhagens selvagem (Ler) e mutante (tz-201) de } A \text {. thaliana. }\end{array}$ & 77 \\
\hline Figura 24 & $\begin{array}{l}\text { Análise de carboidratos de baixo peso molecular por CG-MS em } \\
\text { extratos de plantas das linhagens selvagem (Ler) e mutante (tz- } \\
\text { 201) de A. thaliana. }\end{array}$ & 78 \\
\hline Figura 25 & $\begin{array}{l}\text { Expressão relativa do RNAm thi1 utilizando-se linhagens de } A \text {. } \\
\text { thaliana selvagem (Ler) e mutante (tz-201) crescidas por } 18 \text { dias } \\
\text { em meio sem sacarose ou sob hipoxia. }\end{array}$ & 79 \\
\hline Figura 26 & Atividades específicas de SOD, CAT, APX e GPX em linhagens & 80 \\
\hline
\end{tabular}


selvagem (Ler) e mutante (tz-201) de A. thaliana expostas a diferentes condições luminosas.

Figura 27 Quantificação de $\mathrm{H}_{2} \mathrm{O}_{2}$ e medição de atividade de SOD, CAT, APX e GPX em linhagens selvagem (Ler) e mutante (tz-201) de A. thaliana crescidas sob hipoxia.

Figura 28 Quantificação de $\mathrm{H}_{2} \mathrm{O}_{2}$ e medição de atividade de SOD, CAT, APX e GPX em linhagens selvagem (Ler) e mutante (tz-201) de A. thaliana crescidas na presença e ausência de sacarose.

Figura 29 Quantificação de ascorbato (ASC) e glutationa (GSH) em linhagens selvagem (Ler) e mutante (tz-201) de A. thaliana crescidas na condição controle.

Figura 30 Proteômica. Perfil de proteínas extraídas de linhagens selvagem (Ler) e mutante (tz-201) de A. thaliana.

Figura 31 Proteômica. Eletroforese 2D de proteínas das linhagens selvagem (Ler) e mutante (tz-201) de Arabidopsis thaliana.

Figura 32 Quantificação de danos no DNA por PCR quantitativa (QPCR). Perfil do DNA genômico utilizado na quantificação de danos e amplificação de DNA de mitocôndrias e de cloroplastos.

Figura 33 Quantificação de danos no DNA por PCR quantitativa (QPCR). Amplificação de DNA nuclear e amplificação de DNA de cloroplastos.

Figura 34 Quantificação de danos no DNA por PCR quantitativa (QPCR). Plantas das linhagens selvagem (Ler) e mutante (tz-201) foram submetidas a $0,1 \%$ e $0,05 \%$ de peróxido de hidrogênio e submetidas à QPCR para a quantificação de danos em cloroplastos.

Figura 35 Extração e quantificação de tiamina e de seus ésteres fosfatos, a partir das linhagens selvagem (Ler) e mutante (tz-201) de A. thaliana.

Figura 36 Representação esquemática do desbalanço metabólico causado por THI1 defectivo.

Tabela 1 Local de ação e substratos utilizados por antioxidantes enzimáticos e não-enzimáticos em plantas

Tabela 2 Iniciadores utilizados na RT-qPCR e suas características

Tabela 3 Iniciadores utilizados na QPCR e suas características

Tabela 4 Proteínas expressas diferencialmente em linhagens selvagem (Ler) e mutante (tz-201) de A. thaliana identificadas por espectrometria de massa. 


\section{Lista de Abreviaturas}

\begin{tabular}{|c|c|}
\hline Abreviatura & Significado \\
\hline AAP & 4-aminoantipirina \\
\hline ADP & Adenosina difosfato \\
\hline $\mathrm{AHZ}$ & 2-carboxilato-4-metil-5- $\beta$-(etil adenosina 5 '-difosfato) tiazol \\
\hline ANOVA & Análise de variância \\
\hline AP & Apurínico ou apirimidinico \\
\hline APX & Ascorbato peroxidase \\
\hline ASC & Ascorbato \\
\hline AThTP & Tiamina ligada a ATP \\
\hline ATP & Adenosina trifosfato \\
\hline BER & Reparo por excisão de bases \\
\hline BSA & Albumina sérica bovina \\
\hline BSTFA & N,O-bis-(trimethylsilyl)-trifluoroacetamida \\
\hline $\mathrm{C} / \mathrm{CE} / \mathrm{CEC}$ & Controle/claro-escuro/claro-escuro-claro \\
\hline CAT & Catalase \\
\hline cDNA & DNA complementar \\
\hline CG-MS & Cromatografia gasosa acoplada a espectrometria de massa \\
\hline $\mathrm{CPD}$ & Dímero de pirimidina ciclobutano \\
\hline CVA & Análise de variável canônica \\
\hline DCHBS & 3,5-dicloro-2-hidroxibenzenosulfonico \\
\hline DEPC & Dietil pirocarbonato \\
\hline DNA & Ácido desoxirribonucléico \\
\hline $\mathrm{EC}$ & Classe enzimática \\
\hline EDTA & Ácido etileno-diamino-tetra-acético \\
\hline FAD & Flavina adenina dinucleotídeo \\
\hline G3P & Gliceraldeído 3-fosfato \\
\hline GPX & Glutationa peroxidase \\
\hline GR & Glutationa redutase \\
\hline GSH/GSSG & Glutationa reduzida/oxidada \\
\hline GUS & B-glucuronidase \\
\hline HET & Tiazol \\
\hline HMP & Pirimidina \\
\hline HPLC & Cromatografia líquida de alta pressão \\
\hline HRP & Peroxidase de raiz forte \\
\hline IEF & Focalização isoelétrica \\
\hline Ler & Landsberg erecta \\
\hline Maldi TOF- & Espectrometria de massa usando as técnicas de Matrix-assisted laser \\
\hline TOF- & $\begin{array}{l}\text { desorption/ionization (MALDI) e dois espectrômetros em seqüência (análise por } \\
\text { Time of Flight, TOF) }\end{array}$ \\
\hline MMS & Metil-metano sulfonato \\
\hline $\mathrm{m}-\mathrm{PA}$ & Ácido metafosfórico \\
\hline NADH/NAD + & Nicotinamida adenina dinucleotídeo/NADH oxidado \\
\hline NER & Reparo por excisão de nucleotídeos \\
\hline NMR & Ressonância magnética nuclear \\
\hline OFR & Radical livre de oxigênio \\
\hline PCA & Análise de componente principal \\
\hline PCD & Morte celular programada \\
\hline PCR & Reação em cadeia de polimerização \\
\hline
\end{tabular}




\begin{tabular}{ll}
\hline 3-PGA & 3-fosfoglicerato \\
PGDH & Fosfoglicerato desidrogenase \\
3-PHP & 3-fosfohidroxipiruvato \\
PMF & Peptide mass fingerprinting \\
PSAT & 3-fosfoserina aminotransferase \\
PSP & 3-fosfoserina fosfatase \\
QPCR & PCR quantitativa \\
RT-qPCR & PCR quantitativo sobre cDNA \\
RNA & Ácido ribonucléico \\
ROS & Espécies reativas de oxigênio \\
SDS & Dodecil sulfato de sódio \\
SDS-PAGE & Eletroforese em gel de poliacrimilamida na presença de SDS \\
SL/SLS & Sólido-líquido/sólido-líquido-sólido \\
SOD & Superóxido dismutase \\
T/TP/TPP/TPPP & Tiamina livre/monofosfato/pirofosfato/trifosfato \\
TBS & Solução salina tamponada Tris-ácido bórico \\
TCA & Ácido tricloroacético \\
thi1/THI1 & Gene thil/proteína THI1 \\
thi1 $1_{\text {sa }}$ & Transgênica com o gene thi1 na orientação senso \\
thi1 ${ }_{\text {as }}$ a & Transgênica com o gene thi1 na orientação antisenso \\
Tm & Temperatura de anelamento \\
TMCS & Trimetil-clorosilano \\
TMP & Tiamina monofosfato quinase \\
TPK & Tiamina pirofosfoquinase \\
TRR & Tiorredoxina redutase \\
TRX & Tiorredoxina \\
tz-201 & Linhagem mutante para o gene thi1 \\
UV & Luz ultravioleta (1nm a 380 nm) \\
X-GLUC & 5-bromo-4-cloro-3-indolil- $\beta$-D-glicopiranosídeo \\
\hline
\end{tabular}




\section{Resumo}

O gene thi1 foi isolado a partir de uma biblioteca de cDNA de A. thaliana devido à sua capacidade de complementar mutantes de E. coli para rotas de reparo de DNA. O posterior seqüenciamento desse gene permitiu a identificação de similaridade com genes de fungos ativados em condições de estresse ou ativados na ausência de tiamina (vitamina B1). A síntese de tiamina é de grande importância já que na forma pirofosfatada é coenzima essencial para vários processos vitais das células.

No presente estudo, foi realizada a caracterização funcional do gene thi1 utilizando-se, para tanto, linhagens de A. thaliana mutante e/ou com expressão diferencial desse gene. Foram analisados parâmetros biológicos como viabilidade de sementes, antioxidantes, danos no DNA, e atividade transcricional e traducional do gene thi1. Foi iniciado, também, o processo de padronização da quantificação de tiamina em plantas. Foi observado, para a linhagem mutante, menor viabilidade de sementes, maior produção de antioxidantes e maior quantidade de danos no DNA de cloroplastos. Quanto à atividade transcricional e traducional, foi observado que o gene thi1 apresenta um pico de expressão no período da tarde com um ritmo circadiano em potencial. Além disso, o acúmulo da proteína nos tecidos acompanha o perfil de expressão de RNAm thi1, o que sugere que o modo de regulação primária do gene é em nível transcricional. A análise comparativa de proteína por gel bidimensional entre as linhagens selvagem e mutante permitiu a identificação de quatro proteínas em maior quantidade na mutante, sendo duas identificadas por seqüenciamento: enolase e fosfoglicerato desidrogenase. $\mathrm{Na}$ análise de tiamina foi observado que a linhagem mutante acumula um composto, não identificado, que emite fluorescência no mesmo comprimento de onda que as tiaminas, sendo, provavelmente, um precursor do tiazol.

Os resultados obtidos nesse trabalho indicam que THI1 defectivo acarretaria em desbalanço metabólico e, não necessariamente, que o gene thi1 estaria envolvido em dupla função. Em bactérias, entre os precursores de tiazol, estão a cisteína e o gliceraldeído 3-fosfato (G3P). O G3P em excesso seria deslocado para o ciclo de Calvin a fim de regenerar a ribulose 1,5-bisfosfato. Maior quantidade de G3P, maior taxa fotossintética, maior produção de ROS, maior produção de antioxidantes na mutante. A maior disponibilidade de G3P aumentaria o fluxo de glicólise e, consequentemente, de respiração mitocondrial, aumentando a taxa de ROS. A fosfoglicerato desidrogenase, em maior quantidade na mutante, está envolvida na síntese de cisteina que acarreta na produção de glutationa. A glutationa e a cisteína, por sua vez, atuariam induzindo o promotor da SOD, acarretando, então, na produção de mais antioxidantes. Todos esses antioxidantes estariam envolvidos na detoxificação de ROS presente em excesso na linhagem mutante, que levaria à menor viabilidade de sementes e maior quantidade de danos no DNA. Devido à grande quantidade de ROS, haveria superexpressão de enolase, envolvida no bloqueio da proliferação celular e, subsequentemente, em morte celular programada, o que explicaria o retardo no desenvolvimento da linhagem mutante. 


\section{Summary}

Thi1 gene was previously isolated from A. thaliana cDNA library due to its capacity to complement mutant Escherichia coli defective in DNA repair. Subsequent analysis of the gene nucleotide sequence showed its similarity with yeast genes activated under stress conditions or activated in the absence of thiamine. The thiamine biosynthesis is important because its phosphorilated form is a coenzyme essential to several vital process at the cell.

The present study reports the functional characterization of thi1 gene using A. thaliana mutant line and lineages with differential expression of this gene. It has analyzed biological parameters as seed viability, antioxidants, DNA damage, and transcriptional and translational activities of thi1 gene. It has begun the standardization of the thiamine quantification in plants either. It was observed, in the mutant line, lower seed viability, higher antioxidant production and higher DNA damage amount in chloroplasts. In relation to the transcriptional and translational activities it has observed the higher thi1 mRNA expression in the afternoon suggesting a circadian rhythm. Besides, the protein production has followed the thi1 mRNA expression, which suggest that the primary regulation is under the transcriptional level. The comparative analysis of protein by bidimensional gel between wild-type and mutant line allowed the identification of four proteins in higher amount in the mutant line, two of them identified: enolase and phosphoglycerate dehydrogenase. In the thiamine analysis it has observed the accumulation of an unknown compound in the mutant line, probably a thiazole precursor.

Results obtained in this work indicate that defective THI1 bring about metabolic imbalance and that, not necessarily, thi1 gene is involved in dual role. In bacteria, cisteine and glyceraldeide-3phosphate (G3P) are thiazole precursors. The G3P excess would be switched to Calvin cycle to regenerate ribulose-1,5-diphosphate. If there is a high G3P amount, the photosynthetic rate will increase, followed by the ROS and antioxidant production, as occured in the mutant line. A high G3P availability can increase the glycolysis flux and, consequently, the respiratory rate, increasing the ROS production. The phosphoglycerate dehydrogenase, in higher amount in the mutant line, is involved in cysteine synthesis which bring about glutathione production. Cysteine and glutathione induce the SOD promoter, increasing antioxidants production. All these antioxidants are involved in ROS detoxification, in excess in the mutant line. These ROS would decrease seed viability and increase DNA damage. High ROS amount could induce the overexpression of enolase, involved in blocking cellular growth and, consequently, resulting in programmed cell death, which could explain the delayed development of the mutant line. 


\section{Introdução}

\subsection{Tiamina (vitamina $\left.B_{1}\right)$}

Plantas, bactérias e fungos podem sintetizar tiamina de novo. A tiamina (vitamina B1) é sintetizada a partir da condensação da porção do tiazol com a porção da pirimidina para produzir tiamina monofosfato (TP). Esta é, então, fosforilada produzindo tiamina pirofosfato (TPP), em procariotos. Em eucariotos, TP é produzida diretamente da condensação do tiazol com a pirimidina sendo, em seguida, desfosforilada, produzindo tiamina livre e, subsequentemente, pirofosforilada, produzindo TPP, o cofator ativo (figura 1) (CROFT et al, 2007). Em plantas, sabe-se que o tiazol é sintetizado nos cloroplastos (Julliard \& DouCE, 1991; Belanger et al., 1995), enquanto em fungos é sintetizado nas mitocôndrias (BELANGER et al., 1995; MACHADO et al., 1996).

Tiamina pirofosfato (TPP) ou cocarboxilase é um cofator essencial para dois tipos de enzimas: $\alpha$-ceto ácido desidrogenases e transcetolases. A tiamina atua como cofator da fermentação alcoólica (piruvato descarboxilase), descarboxilação oxidativa do piruvato (piruvato desidrogenase), ciclo de Krebs ( $\alpha$-ceto glutarato desidrogenase), via da pentose-fosfato (transcetolase), ciclo de Calvin (transcetolase) e na biossíntese e catabolismo de alguns aminoácidos (figura 2). 
PIRUVATO

$+$

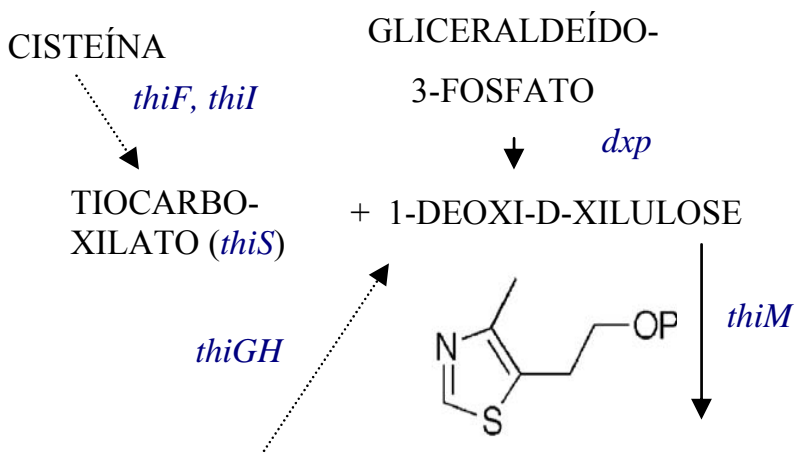

AMINOIMIDAZOL-

RIBONUCLEOTÍDEO

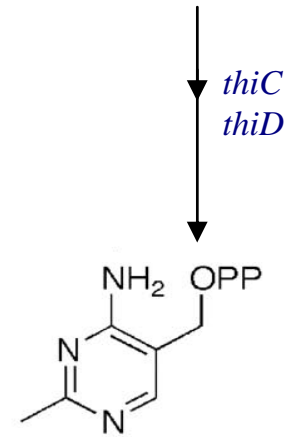

HIDROXIMETILPIRIMIDINA PIROFOSFATO

thi1 ??
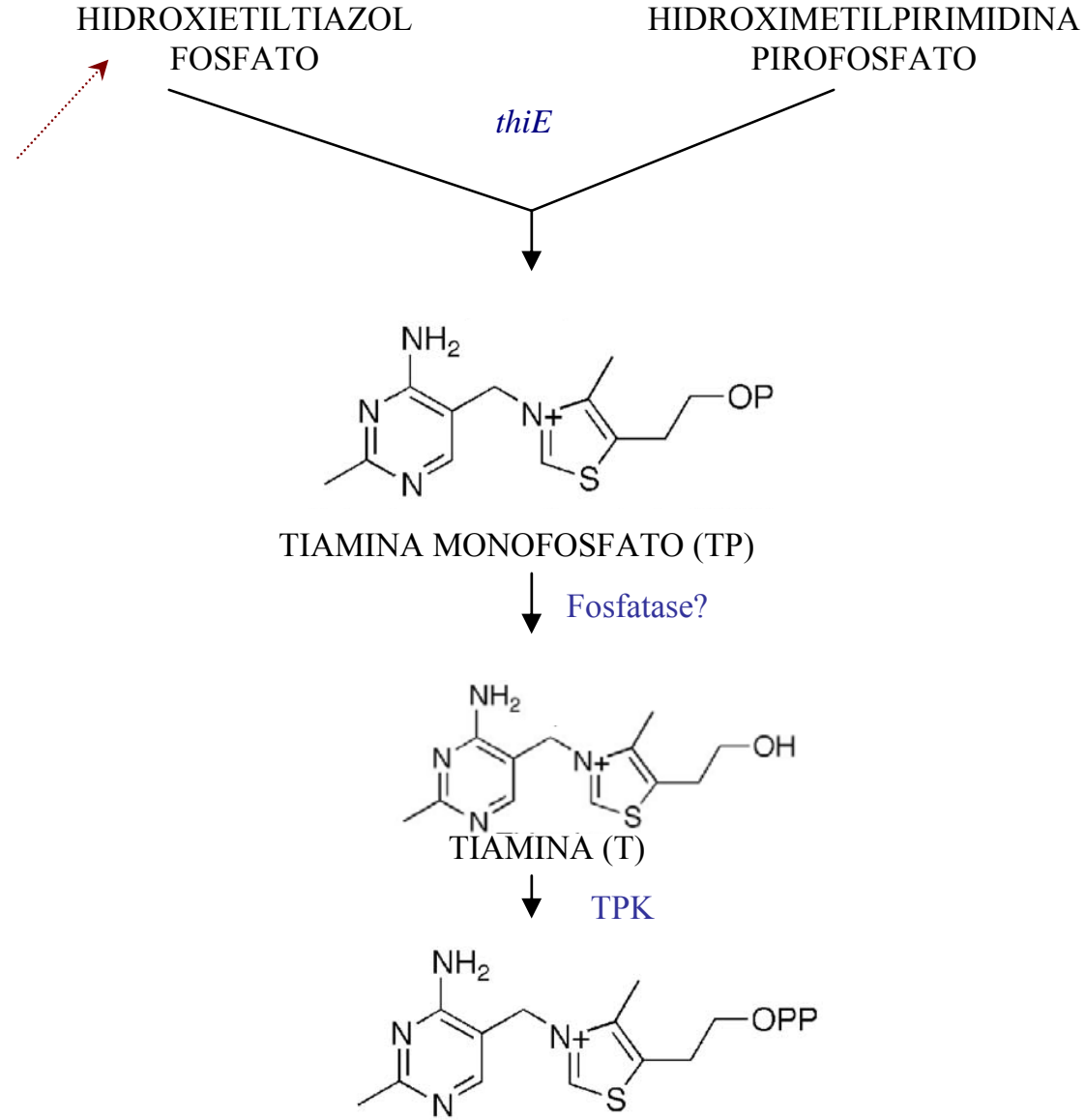

TIAMINA PIROFOSFATO (TPP)

Figura 1: Via de biossíntese de tiamina. Esquema baseado na síntese da vitamina B1 em E. coli (rota de síntese de tiazol) e na alga verde Chlamydomonas reinhardtii (rota final da via). TP é gerada da condensação de 5-hidroxietil-4-metiltiazol fosfato e 4-amino-5hidroximetil-2-metilpirimidina pirofosfato pela ação da TMP quinase (THIE). Em E. coli, thi1 auxilia na produção de algum elemento da porção tiazólica da via (não se sabe exatamente onde). A porção pirimidínica é sintetizada de aminoimidazol ribonucleotídeo, um intermediário na biossíntese de histidina e purina, via ação de THIC e THID. Para gerar o cofator ativo (TPP) em C. reinhardtii, TP é primeiramente desfosforilada por uma fosfatase desconhecida, e então, subsequentemente, pirofosforilada por tiamina pirofosfoquinase (TPK). Genes envolvidos em diferentes etapas desta via estão representados em azul (Modificado de CROFT et al, 2007). 


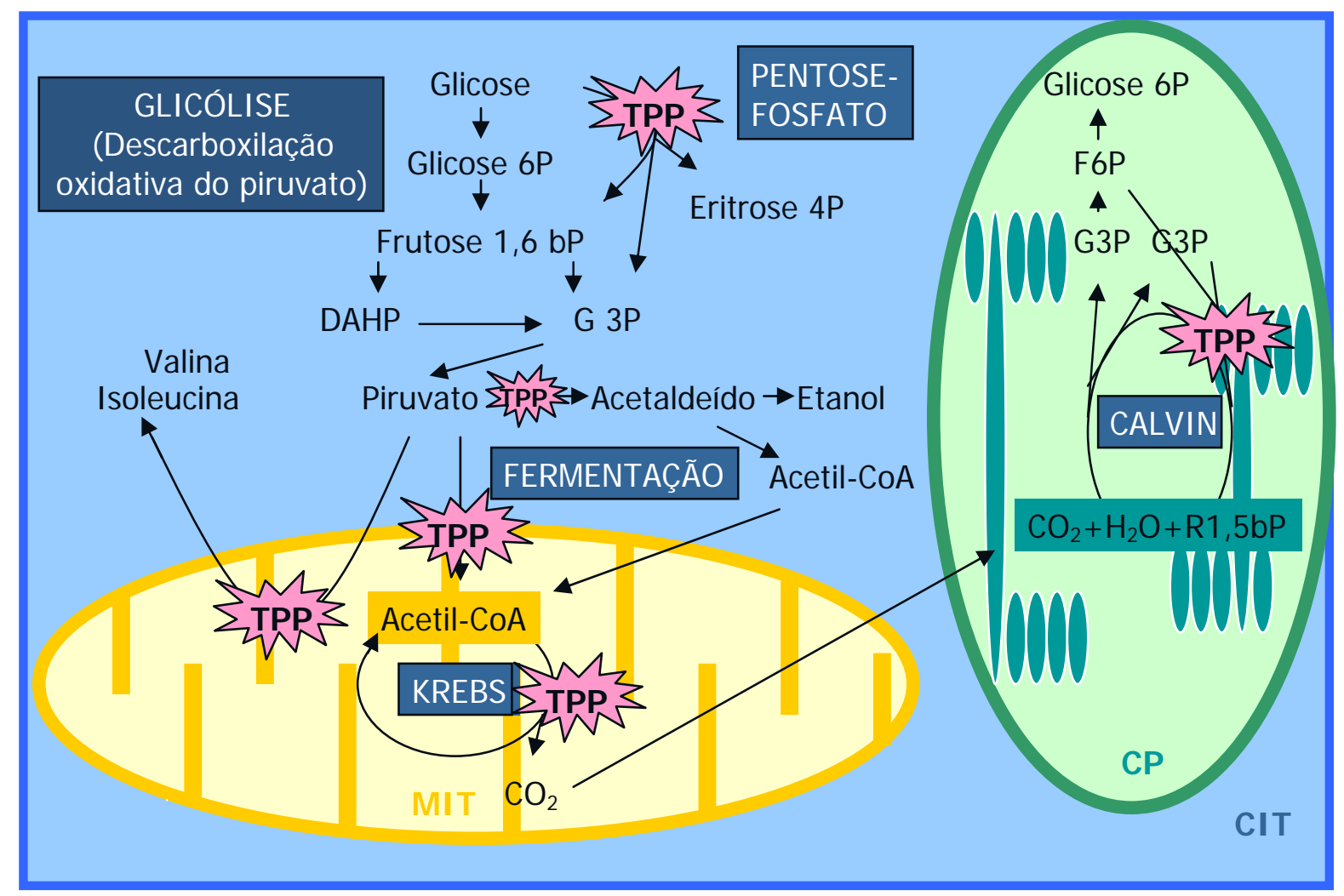

Figura 2: Esquema simplificado das vias metabólicas em que a TPP participa como cofator. MIT: mitocôndria, CP: cloroplasto, CIT: citoplasma.

A via de biossíntese de tiamina é bem conhecida em bactérias, mas ainda pouco compreendida em leveduras e plantas. Sabe-se, contudo, que em leveduras e bactérias, há uma regulação negativa da maioria dos genes envolvidos nesta via devido à presença de TPP no meio de crescimento (KAWASAKI et al., 1990; PRAEKelt et al., 1994). Em A. thaliana, entretanto, a tiamina parece não exercer um papel regulatório na expressão do gene thi1 (PAPINI-TERZI et al, 2003).

Vias que utilizam TPP como cofator podem ser responsáveis pela produção de espécies reativas de oxigênio (ROS), como oxigênio singlete $\left({ }^{1} \mathrm{O}_{2}\right)$, radical superóxido $\left(\mathrm{O}_{2}{ }^{\bullet}\right)$, peróxido de hidrogênio $\left(\mathrm{H}_{2} \mathrm{O}_{2}\right)$ e radical hidroxila $\left({ }^{\bullet} \mathrm{OH}\right)$.

\subsection{Espécies ativas de oxigênio}


Altas concentrações de oxigênio têm se mostrado tóxicas (HALLIWELL \& GUTTERRIDGE, 1999). Esta toxicidade deve-se à possibilidade de formação de espécies ativas de oxigênio (ROS, do inglês reactive oxygen species), tais como oxigênio singlete $\left({ }^{1} \mathrm{O}_{2}\right)$, radical superóxido $\left(\mathrm{O}_{2}{ }^{\bullet-}\right)$, peróxido de hidrogênio $\left(\mathrm{H}_{2} \mathrm{O}_{2}\right)$ e radical hidroxila ( $\left.{ }^{\circ} \mathrm{OH}\right)$ (DALTON, 1995), os três últimos resultantes da transferência de 1, 2 ou 3 elétrons do oxigênio molecular, respectivamente. Para exemplificar a formação de ROS, pode-se observar na figura 3 a redução de oxigênio à água.

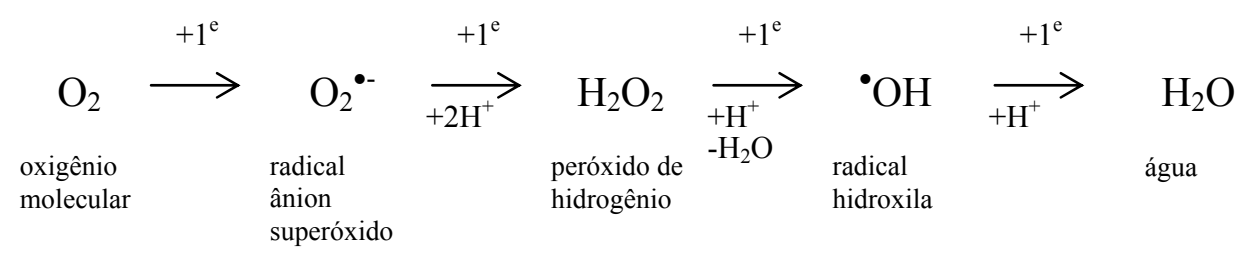

Figura 3: Formação de ROS durante a redução de oxigênio à água

Entre as ROS existem átomos ou moléculas que possuem elétrons desemparelhados: são os radicais livres de oxigênio (OFR, do inglês oxygen free radical). Esses são potencialmente tóxicos para as células. Alguns produtos do ataque desses radicais podem interferir com a função dos ácidos nucléicos, gerando preferencialmente quebras na dupla fita (VAN SLUYS et al, 1986) e alterações nas seqüências de base, ocasionando mutações (PunCHARD \& KELLY, 1996), o que pode levar a anormalidade de algumas funções ou até mesmo à morte do organismo.

A produção de ROS, em plantas, resulta de vias como fotorespiração e fotossíntese nos cloroplastos, e respiração mitocondrial (MitTLER, 2002). Nos cloroplastos pode haver a produção de oxigênio singlete $\left({ }^{1} \mathrm{O}_{2}\right)$, quando uma molécula de clorofila excitada pela absorção de um fóton, transfere energia de um elétron excitado para um oxigênio na sua forma estável, ao invés de transferir para o próximo componente da cadeia de transporte de elétrons (figura 4). $\mathrm{O}^{1} \mathrm{O}_{2}$ é estável em ambientes 
hidrofóbicos de modo que pode iniciar o processo de peroxidação lipídica das membranas tilacóides e danificar os cloroplastos (DALTON, 1995).

As reações que ocorrem nas membranas dos tilacóides durante a fotossíntese são responsáveis por geração de condições fortemente redutoras. Um dos componentes de maior poder redutor desta fase é a ferredoxina (cadeia de transporte de elétrons, fotossistema I), que participa como doadora de elétrons ao NADP, para produzir NADPH. Entretanto, o potencial redox da ferredoxina $(-0,43 \mathrm{~V})$ é muito similar ao requerido para reduzir $\mathrm{O}_{2}$ a $\mathrm{O}_{2}{ }^{\bullet-}(-0,45 \mathrm{~V})$, de modo que pode, então, ocorrer formação de $\mathrm{O}_{2}{ }^{\bullet-}$ ao invés de NADPH (MISRA \& FRIDOVICH, 1971) (figura 4).

A enzima ribulose-1,5-bisfosfato carboxilase/oxigenase (Rubisco), responsável por fixar $\mathrm{CO}_{2}$ a compostos orgânicos na fotossíntese, também pode funcionar como oxigenase (fotorespiração). Como carboxilase, produz 2 moléculas de 3-fosfoglicerato, ao passo que como oxigenase, produz 1 molécula de 3-fosfoglicerato e outra de 2fosfoglicolato. A primeira é metabolizada normalmente participando do ciclo de Calvin, enquanto 2-fosfoglicolato, em plantas superiores, é transportado aos peroxissomos e, então, oxidado a 2-fosfoglioxilato e $\mathrm{H}_{2} \mathrm{O}_{2}$ e glioxilato. Peroxissomos contém grandes quantidades de catalase que convertem $\mathrm{H}_{2} \mathrm{O}_{2}$ a $\mathrm{H}_{2} \mathrm{O}$ e $\mathrm{O}_{2}$ (DALTON, 1995) (figura 4).

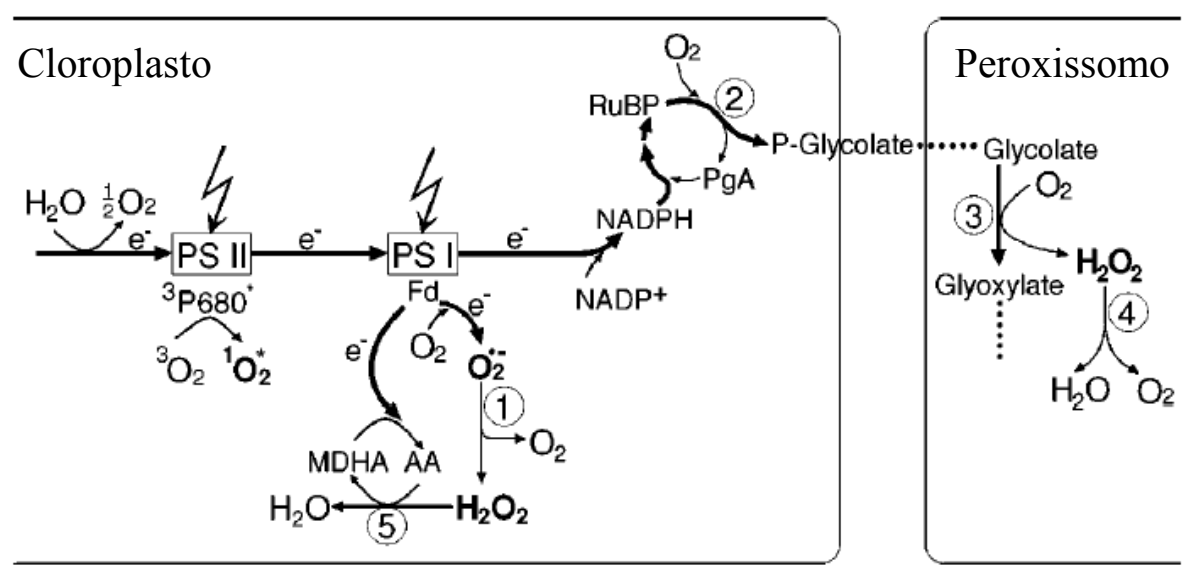

Figura 4: Produção de ROS nos cloroplastos e peroxissomos. Pode ocorrer a produção de oxigênio singlete no fotossistema II (PS II) quando há transferência de energia de um elétron excitado para oxigênio em sua forma estável, e pode ocorrer também, a redução 
de oxigênio no fotossistema I (PSI) quando a ferredoxina $(\mathrm{Fd})$ doa elétrons ao oxigênio ao invés de doá-lo ao NADP, gerando radical superóxido e $\mathrm{H}_{2} \mathrm{O}_{2}$. A enzima Rubisco $(\mathrm{RuBP})$ pode atuar como oxigenase no processo de fotorrespiração, que leva à produção de $\mathrm{H}_{2} \mathrm{O}_{2}$ dentro dos peroxissomos. Setas em negrito mostram as principais rotas de transporte de elétrons. Enzimas chaves são mostradas em números circulados: 1) superoxido dismutase, 2) Rubisco, 3) glicolate oxidase, 4) catalase, e 5) ascorbato peroxidase. (Modificado de APEL \& HIRT, 2004)

Já na cadeia de transporte de elétrons mitocondrial, há redução de $\mathrm{O}_{2}$ a $\mathrm{H}_{2} \mathrm{O}$, sendo esta reação bastante eficiente em plantas. Nesse caso, há produção de $\mathrm{H}_{2} \mathrm{O}$ praticamente sem produção de $\mathrm{O}_{2}{ }^{\bullet-}$ ou $\mathrm{H}_{2} \mathrm{O}_{2}$. Entretanto, há componentes desta cadeia que não são tão eficientes. Por exemplo, a flavoproteína NADH desidrogenase pode produzir $\mathrm{O}_{2}{ }^{\bullet-}$ a partir de $\mathrm{O}_{2}(\mathrm{RICH} \&$ BONNER, 1978).

Plantas também produzem ROS como sinalizadores no controle de processos como morte celular programada, respostas a estresse biológico, defesa a patógenos e sinalização sistêmica (MITTLER, 2002). Enquanto sob condições normais a produção de ROS é baixa, em condições de estresse há uma quebra na homeostase das células que aumentam a produção destas espécies (POLLE, 2001). As plantas desenvolveram um sistema de defesa a ROS que envolve tanto a limitação em sua formação quanto sua remoção (ALSCHER et al, 2002).

A importância dos radicais livres pode ser vista pelo número e diversidade de antioxidantes biológicos presentes nas células (PUNCHARD \& KELLY, 1996). A defesa primária, não enzimática, inclui antioxidantes como ascorbato e glutationa em regiões hidrofílicas da célula, e $\alpha$-tocoferol (vitamina E) e $\beta$-caroteno em regiões hidrofóbicas (DALton, 1995). Entre as enzimas antioxidantes, destacam-se a superóxido dismutase (SOD, E.C 1.15.1.1), ascorbato peroxidase (APX, E.C 1.11.1.11) e catalase (CAT, E.C 1.11.1.6). SOD age convertendo $\mathrm{O}_{2}{ }^{\bullet-}$ em $\mathrm{H}_{2} \mathrm{O}_{2}$, e, APX e CAT detoxificam $\mathrm{H}_{2} \mathrm{O}_{2}$. APX requer ascorbato como intermediário para a liberação de $\mathrm{H}_{2} \mathrm{O}$, enquanto CAT converte $\mathrm{H}_{2} \mathrm{O}_{2}$ diretamente em $\mathrm{H}_{2} \mathrm{O}$ e $\mathrm{O}_{2}$. SOD, APX, e CAT, juntamente com ácido ascórbico e 
glutationa, constituem uma maquinaria altamente eficiente para detoxificar $\mathrm{O}_{2}{ }^{\bullet-}$ e $\mathrm{H}_{2} \mathrm{O}_{2}$ (MitTler et al, 2004). Como pode-se observar na tabela 1, SOD, APX, ASC e GSH são encontrados em quase todos os compatimentos celulares, enquanto CAT é encontrada somente nos peroxissomos e GPX principalmente no citoplasma (MITTLER et al, 2002).

Tabela 1: Local de ação e substratos utilizados por antioxidantes enzimáticos e não-enzimáticos em plantas (Modificado de MiTTLER, 2002)

Antioxidantes $\quad$ Localização $\quad$ Substratos

\begin{tabular}{ccc}
\hline $\begin{array}{cc}\text { Superóxido dismutase } \\
\text { Catalase }\end{array}$ & Cp., Cit., Mit., Per., Apo. & $\mathrm{O}_{2}{ }^{\bullet-}$ \\
Ascorbato peroxidase & Cp., Cit., Mit., Per., Apo. & $\mathrm{H}_{2} \mathrm{O}_{2}$ \\
Glutationa peroxidase & Per. & $\mathrm{H}_{2} \mathrm{O}_{2}$ \\
Ascorbato & Cit. & $\mathrm{H}_{2} \mathrm{O}_{2}, \mathrm{ROOH}$ \\
Glutationa & Cp., Cit., Mit., Mer., Apo. & $\mathrm{H}_{2} \mathrm{O}_{2}$
\end{tabular}

Abreviações: Apo.: apoplasto; Cp.: cloroplastos; Cit.: citossol; Mit.: mitocôndria; Per.: peroxissomos.

\subsection{Reparo de DNA}

A diversidade dos organismos vivos e o sucesso em colonizar quase todas as partes da superfície terrestre dependem de mudanças genéticas acumuladas ao longo de milhões de anos, que permitem aos organismos se adaptarem a condições em modificação e colonizarem novos hábitats. Entretanto, do ponto de vista de um único organismo, as mudanças genéticas podem ser prejudiciais. Para sobreviverem e se reproduzirem, os indivíduos devem ser geneticamente estáveis, o que é garantido não só pela complexa maquinaria responsável pela replicação do DNA, mas também por meio de mecanismos que corrigem e evitam alterações que constantemente ocorrem no DNA (AlBERTs et al., 2002). 
Apesar de se saber bastante sobre reparo de DNA e os efeitos biológicos da persistência de lesões em microorganismos e mamíferos, muito se deve aprender sobre o mecanismo de reparo em plantas (BRITT, 1996). Projetos de seqüenciamento de genomas em plantas modelo tais como arroz (monocotiledônia) e Arabidopsis (dicotiledônia), permitiram a identificação de grupos de genes inteiros relacionados a reparo de DNA em plantas superiores (KIMURA \& SAKAGUCHI, 2006).

As lesões na molécula de DNA podem acarretar diferentes conseqüências para as células. Existem lesões que não apresentam efeitos biológicos, enquanto outras apresentam efeitos deletérios. As lesões são consideradas mutagênicas quando há alteração da informação genética, ou citotóxicas quando impedem o avanço das DNA e RNA polimerases durante a replicação e a transcrição do DNA, respectivamente, interferindo na manutenção de atividades celulares fundamentais (BRITT, 1996).

Em geral, lesões no DNA podem ser classificadas em 3 grupos: bases desemparelhadas, quebras na cadeia fosfodiéster (simples ou dupla fita) e bases modificadas quimicamente. Estas lesões podem ser causadas por reações de hidrólise, alquilação (adição de grupos metil ou etil), oxidação e radiação (ionizante ou UV). Cada lesão é corrigida por diferentes vias de reparo (BRITT, 1996).

Entre os danos causados por hidrólise, o mais comum é a perda de bases pela hidrólise da ligação glicosídica (liga a base ao esqueleto fosfodiéster da molécula de DNA). Um sítio abásico (figura 5B) pode bloquear a replicação e a transcrição do DNA, e ser letal para as células. Por isso, esses são rapidamente reconhecidos e reparados. O segundo tipo de dano causado por hidrólise é a desaminação de citosina (figura 5A) e de 5-metil-citosina, resultando na formação de uracil e timina, respectivamente. Uracil é rapidamente reconhecida como uma base inapropriada ao DNA e é excisada pela uracil 
glicosilase. Timina, entretanto, não é reconhecida como um dano ocasionando a transição C para T (BRITT, 1996).

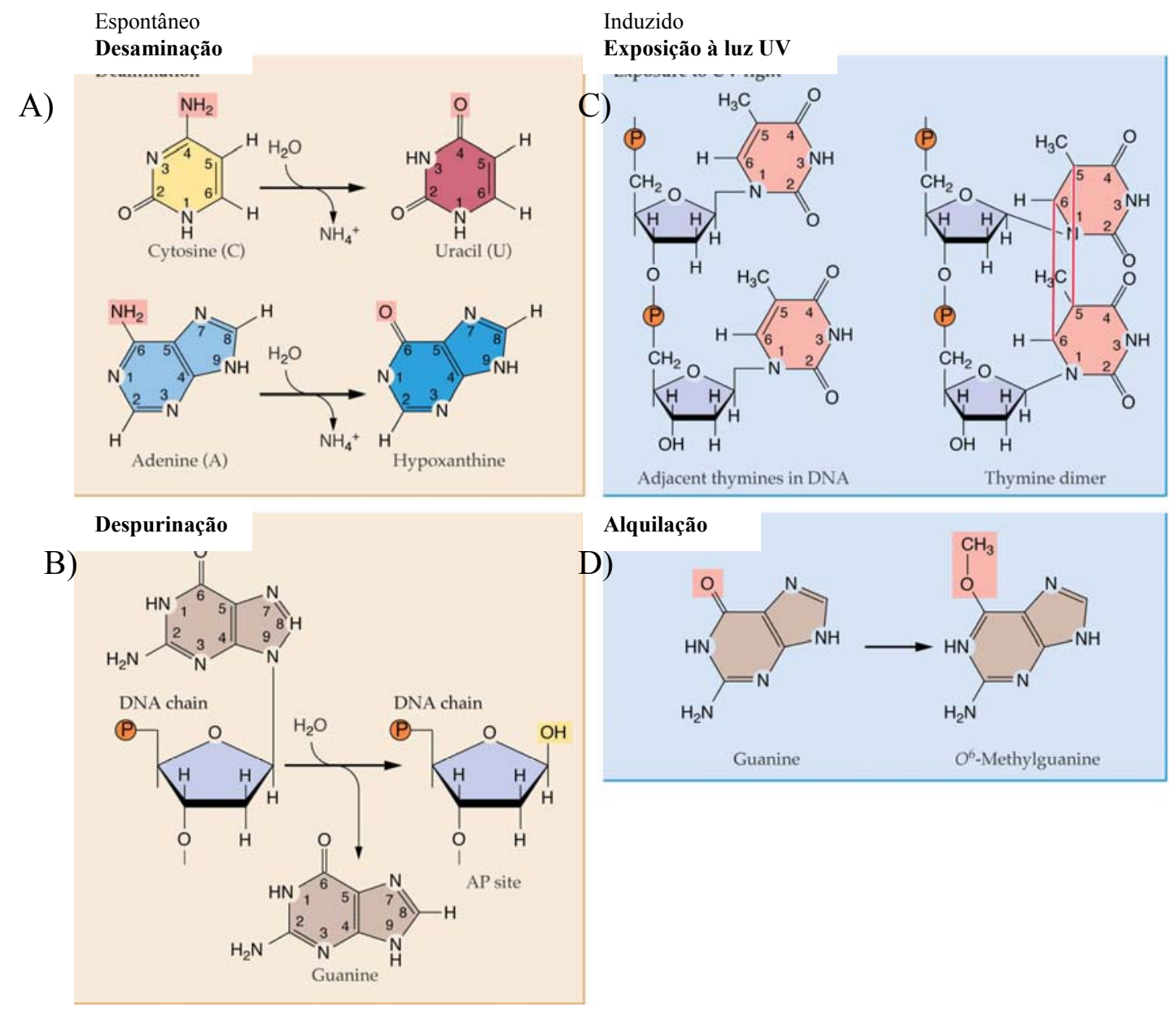

Figura 5: Danos no DNA. Um dos principais tipos de danos que pode ocorrer é a desaminação das bases citosina e adenina (A). Outro evento é a perda de bases formando um sítio abásico no DNA (B). Luz UV-A (320 a 400nm) e UV-B (280 a $320 \mathrm{~nm}$ ) induzem a formação de dímeros de pirimidina entre bases de pirimidinas adjacentes (C). Alquilação de bases do DNA resulta na adição de grupos metil (ou etil) em várias posições do anel (D) ( Modificado de BUCHANAN et al, 2000).

O produto de alquilação mais comum é a 7-metil-adenina, que não é considerada mutagênica. Já a 3-metil-adenina pode bloquear a replicação do DNA. Um terceiro produto de alquilação é a $\mathrm{O}^{6}$-metil-guanina (figura 5D), que pareia eficientemente com timina e, portanto, é potencialmente mutagênica (BRITT, 1996).

A maioria das lesões causadas no DNA por oxidantes ocorre, principalmente, nas bases dos nucleotídeos. Apesar de peróxido de hidrogênio e radicais superóxido não 
reagirem com o DNA, os radicais hidroxil são os mais reativos seguidos pelo oxigênio singlete (MOLLER et al., 2007). A modificação mais comumente observada é a 8hidroxiguanina, que pode parear tanto com A quanto com C (BRITT, 1996).

Radiação ionizante (raios-X) difere de radiação UV por não possuir um alvo específico. O alvo mais freqüente desse tipo de radiação é a água, produzindo radicais hidroxil, e a maioria dos danos no DNA são causados pela interação desse ROS com DNA (BRITT, 1996). Os dímeros de pirimidina, nas formas ciclobutano (CPD) ou 6-4 pirimidinona, constituem $75 \%$ e $25 \%$, respectivamente, das lesões no DNA induzidas por UV (figura 5C). Tem se mostrado que os dímeros de pirimidina bloqueiam a ação das DNA polimerases. Na ausência de reparo, um único dímero de pirimidina é suficiente para eliminar a transcrição do gene em que ele está alocado. Evidências sugerem que RNA polimerases II de mamíferos permanecem no sítio lesionado, o que pode reduzir a concentração de RNA polimerase livre (BRITT, 1996)

Entre as vias de reparo de DNA há a reversão direta de dímeros de pirimidina (fotorreativação), reparo por excisão (de bases e de nucleotídeos) e reparo de quebra de cadeia fosfodiéster.

Algumas mutações induzidas por UV podem ser revertidas por comprimentos de onda de luz visível ou de UV-A. Esta conversão, chamada fotorreativação, é catalisada por fotoliases (figura 6). Estas enzimas ligam-se especificamente à CPDs e, com a absorção de um fóton de comprimento de luz apropriado (350-450nm), revertem diretamente os danos (BUCHANAN et al, 2000). 


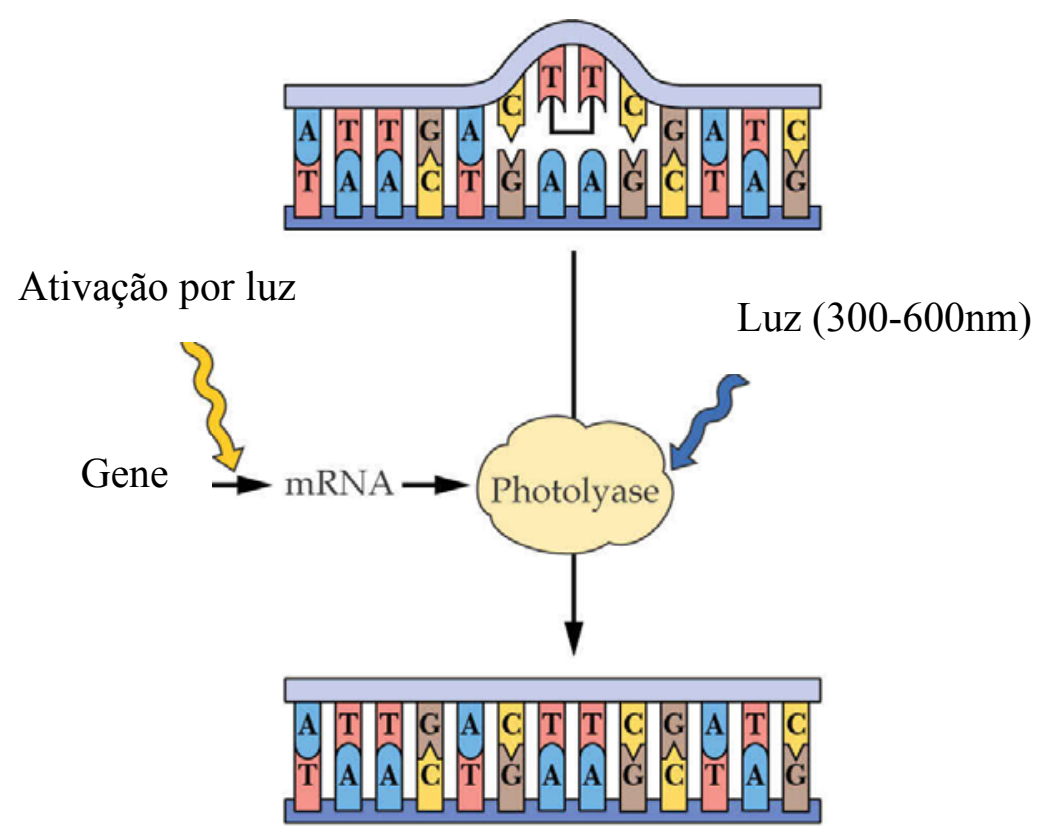

Figura 6: Reparo de DNA por fotorreativação. Fotoliase catalisa o reparo de dímeros de pirimidina. As enzimas usam energia da luz visível para quebrar ligações carbonocarbono que ligam resíduos de pirimidina adjacentes (dímeros de pirimidina) (Modificado de BUCHANAN et al, 2000).

Em contraste com fotorreativação, vias de reparo por excisão, não revertem as lesões diretamente, mas as substituem por nucleotídeos corretos resultados de leitura da fita complementar. Estas vias de reparo por excisão dividem-se em duas categorias: reparo por excisão de bases (BER, do inglês “base excision repair”) (figura 7A) e reparo por excisão de nucleotídeos (NER, do inglês "nucleotide excision repair") (figura 7B). BER remove uma única base danificada por meio da ação de DNA glicosilases específicas. A ação destas enzimas resulta em sítios apurinicos ou apirimidicos (AP) com o esqueleto de açúcar-fosfato intacto. Em seguida, uma AP endonuclease cliva a ligação fosfodiéster no sitio AP. Uma desoxirribose fosfodiesserase, então, remove a molécula desoxirribose remanescente. Em seguida, DNA polimerase e DNA ligase restauram a fita (BUCHANAN et al, 2000). O NER difere do BER por reconhecer um espectro de lesões maior (de sítios abásicos a dímeros de pirimidina), e por iniciar a remoção do dano (fragmentos de até 30 bases) gerando cortes na fita danificada. $\mathrm{O}$ 
oligonucleotídeo com as bases danificadas é excisado depois do desenrolamento do

DNA por uma helicase. Uma DNA polimerase e DNA ligase restauram a fita (BRITT, 1996).

A)

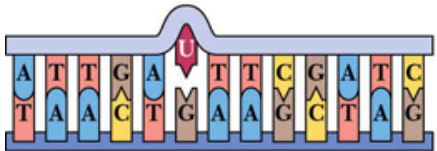

B)
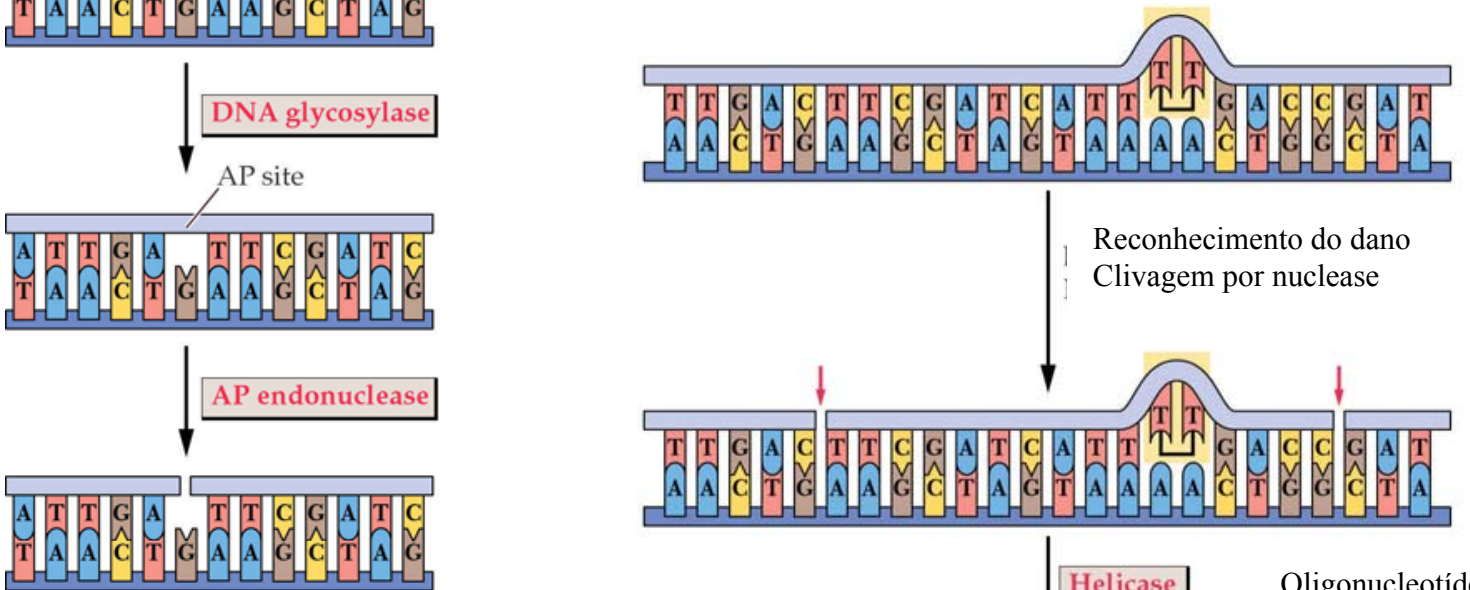

Deoxyribose phosphodiesterase
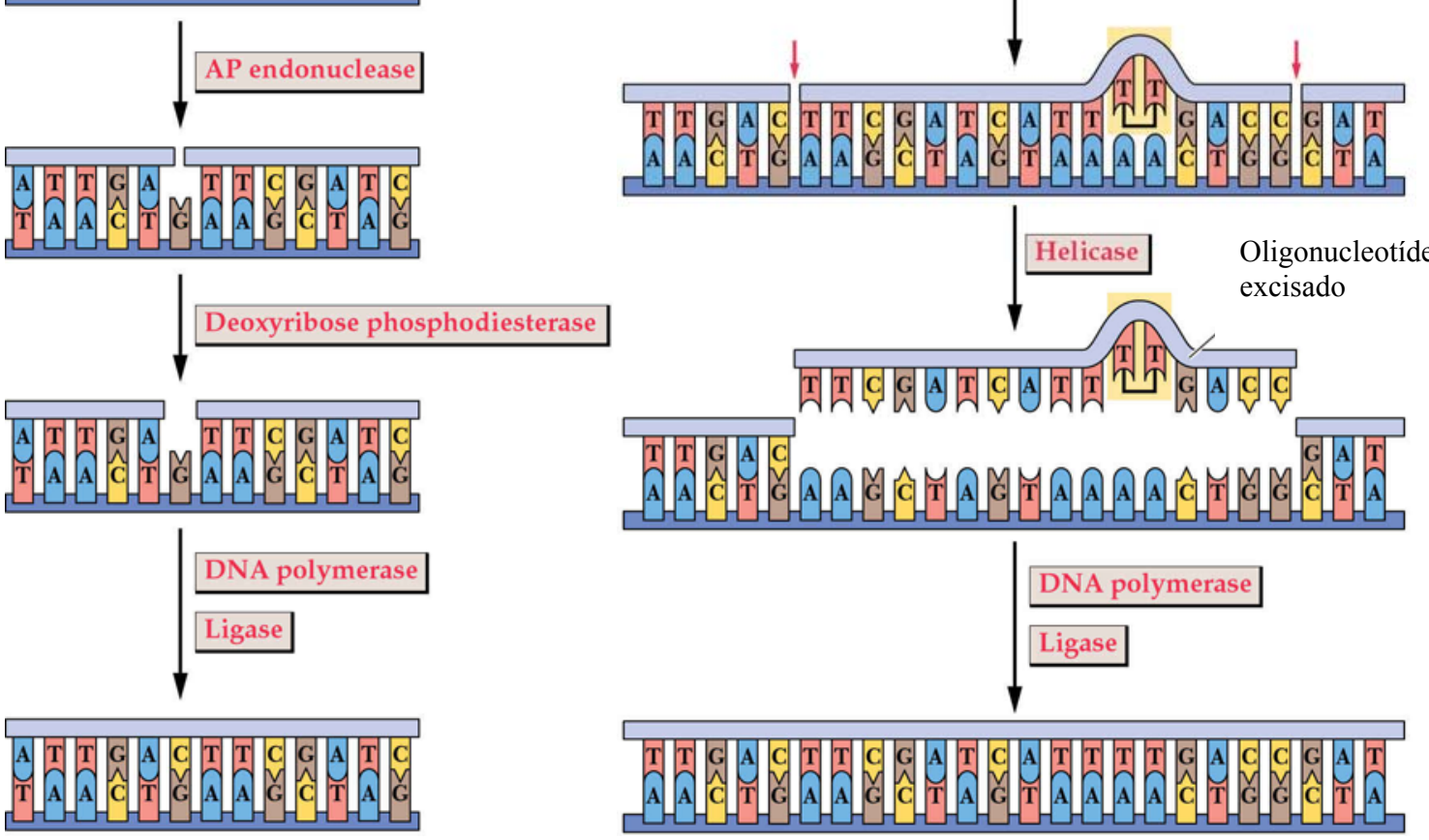

Figura 7: Reparo de DNA por excisão. A: Reparo por excisão de bases. O uracil formado pela desaminação de citosina é removido pela ação da DNA glicosilase. A AP endonuclease reconhece o sítio AP e cliva a fita de DNA no local. Desoxirribose fosfodiesserase, então, remove a molécula desoxirribose remanescente. A DNA polimerase e a ligase reparam a fita, restaurando a base. B: Reparo por excisão de nucleotídeos. O dano no DNA é inicialmente reconhecido por endonucleases e clivado (setas vermelhas). O oligonucleotídeo que contém as bases danificadas é, então, excisado depois do desenrolamento do DNA pela helicase. DNA polimerase e ligase reparam a fita resultante (Modificado de BUCHANAN et al, 2000).

Existem, também, os mecanismos de reparo pós-replicação, que permitem a sobrevivência das células apesar da persistência dos danos. Eles atuam de maneira a 
viabilizar a polimerização do DNA na presença de elevado número de lesões que causariam o bloqueio da replicação. Há dois mecanismos: síntese translesão e reparo por recombinação. Na síntese translesão, o complexo da DNA polimerase, durante a replicação, quando encontra um dano na fita molde, ultrapassa o local danificado e continua a síntese de DNA. Esse processo é potencialmente mutagênico, já que a DNA polimerase não repara o dano, mas insere adeninas no local ao invés da sequência de DNA original (BUCHANAN et al., 2000). Em E. coli, as proteínas umuC,D ligam-se à DNA polimerase e alteram a estringência de incorporação de nucleotídeos, capacitando a realização da síntese translesão. Entretanto, devido ao seu potencial de gerar mutações, as proteínas umuC,D são expressas somente quando a célula é exposta a uma dose substancial de agentes que danificam o DNA. Quando os danos no DNA são extensos, uma alternativa é o reparo por recombinação (figura 8). A DNA polimerase pára a replicação quando uma lesão é encontrada na fita molde e a replicação do DNA é retomada após o dano. A fita de DNA é corrigida por recombinação homóloga do DNA com a fita parental complementar, usando enzimas de recombinação específicas. DNA polimerases e DNA ligase reparam a fita parental complementar (BUCHANAN et al., 2000; BRITT, 1996). 


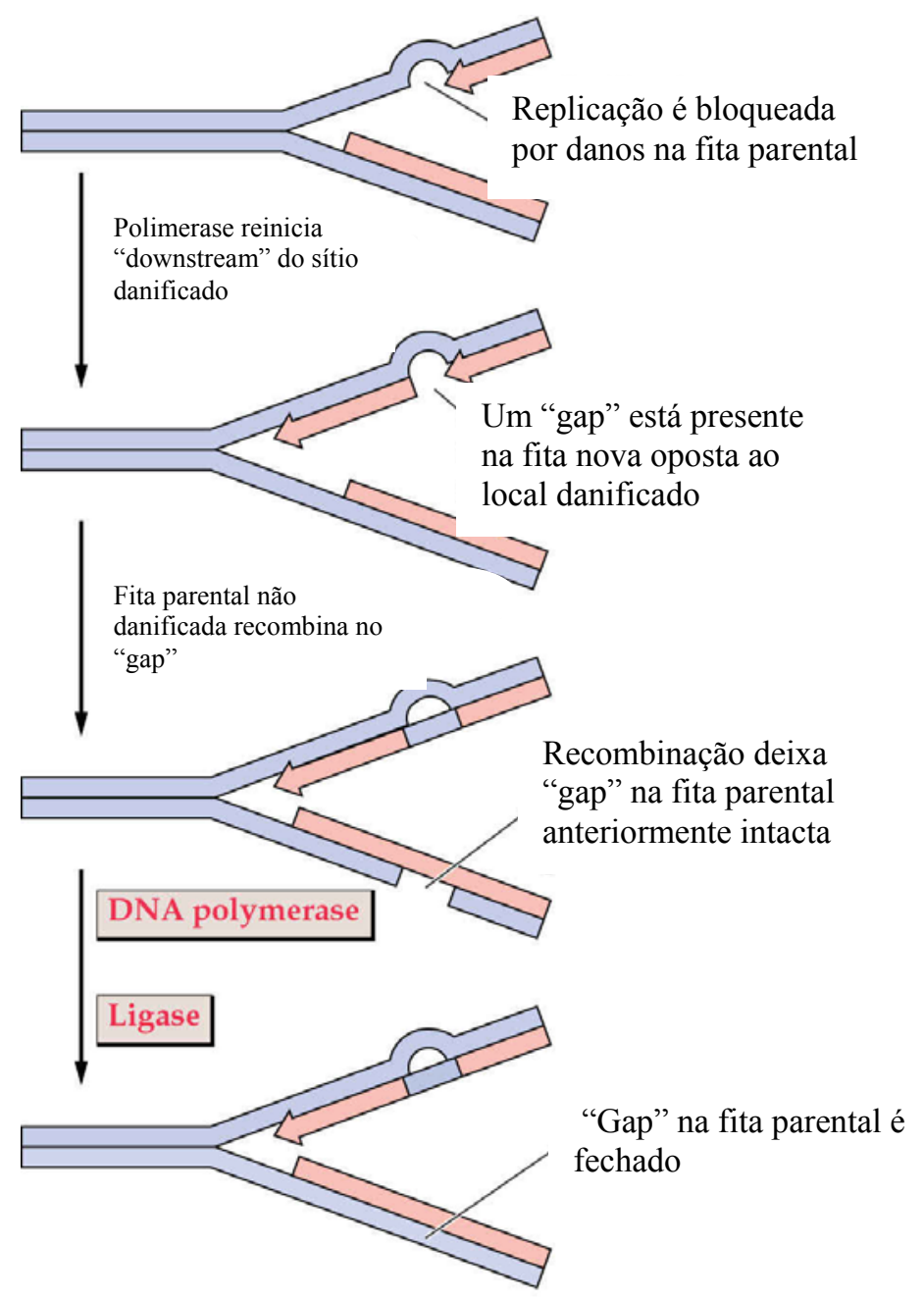

Figura 8: Reparo do DNA por recombinação. A DNA polimerase pára a replicação quando uma lesão é encontrada na fita molde e a replicação do DNA é retomada após o dano. A lesão na fita de DNA é corrigida por recombinação homóloga do DNA com a fita parental complementar, usando enzimas de recombinação específicas. DNA polimerases e DNA ligase reparam a lesão da fita parental complementar (Modificado de BUCHANAN et al., 2000)

Cloroplastos e mitocôndrias têm seu próprio DNA e sistemas de reparo e replicação (KIMURA \& SAKAGUCHI, 2006). A maioria dos estudos sobre reparo se concentra no DNA nuclear, enquanto que os mecanismos de reparo do genoma de cloroplastos e mitocôndrias são pouco estudados. Por muito tempo acreditou-se que não seria necessário reparo nestas organelas devido à existência de várias cópias desses genomas por organela, como também pela presença de várias organelas por célula. 
Entretanto, BOHR \& DiANOv (1999) observaram que existe reparo eficiente de danos oxidativos do DNA nas mitocôndrias.

\subsection{Gene thi1}

O gene nuclear thi1 de A. thaliana foi isolado a partir de uma biblioteca de cDNA devido à sua capacidade em complementar cepas bacterianas mutantes para rotas conhecidas de reparo de DNA (MACHADO et al., 1996). A análise comparativa realizada em banco de dados permitiu a identificação de similaridade entre o gene thi1 e genes de fungos ativados em situação de estresse como presença de etanol, cobre, cloro e aquecimento (sti35 - CHOI et al., 1990) ou ativados na ausência de tiamina (nmt1 MAundrell, 1990; nmt2 - MANETti et al., 1994; THI4 - PraeKelt et al., 1994). Genes ortólogos a thi1 de A. thaliana também foram observados em plantas como Zea mays (BELANGER et al., 1995), Alnus glutinosa (RIBEIRo et al., 1996) e Citrus sinensis (JACOB-WILK et al., 1997), e em arqueobactérias. Thermotoga maritima é a única eubactéria caracterizada até o momento que apresenta um gene similar a thi1, provavelmente resultado de transferência horizontal (NELSON et al, 1999).

MACHADO et al. (1997) realizaram experimentos com o gene THI4 de Saccharomyces cerevisiae, uma linhagem auxotrófica para tiamina, testando a sensibilidade desta a agentes genotóxicos (MMS e UV). Observou-se maior número de mutantes respiratórios (petites), evidenciando uma atividade anormal das mitocôndrias desse mutante. O gene thi1 de A. thaliana foi capaz de restaurar a protrofia de THI4 para tiamina e reduzir a formação de mutantes respiratórios após tratamento com MMS e UV.

PAPINI-TERZI et al. (2003) verificaram que a linhagem mutante tz-201 auxotrófica para tiamina (FEENSTRA, 1964) possui uma mutação pontual única em uma região conservada do gene thi1 (figura 9) e que o cDNA tz-201 não complementa 
leveduras THI4 mutantes, enquanto o cDNA da linhagem selvagem confere total complemetação. PAPINI-TERZI et al. (2003) verificaram também redução na expressão de mRNA em condições de escuro total, maior expressão nas folhas do que nas raízes e que a expressão do gene thi1 não é aumentada significantemente na ausência de tiamina, como observado para o homólogo de Saccharomyces cerevisiae, THI4 (PRAEKELT et al., 1994).

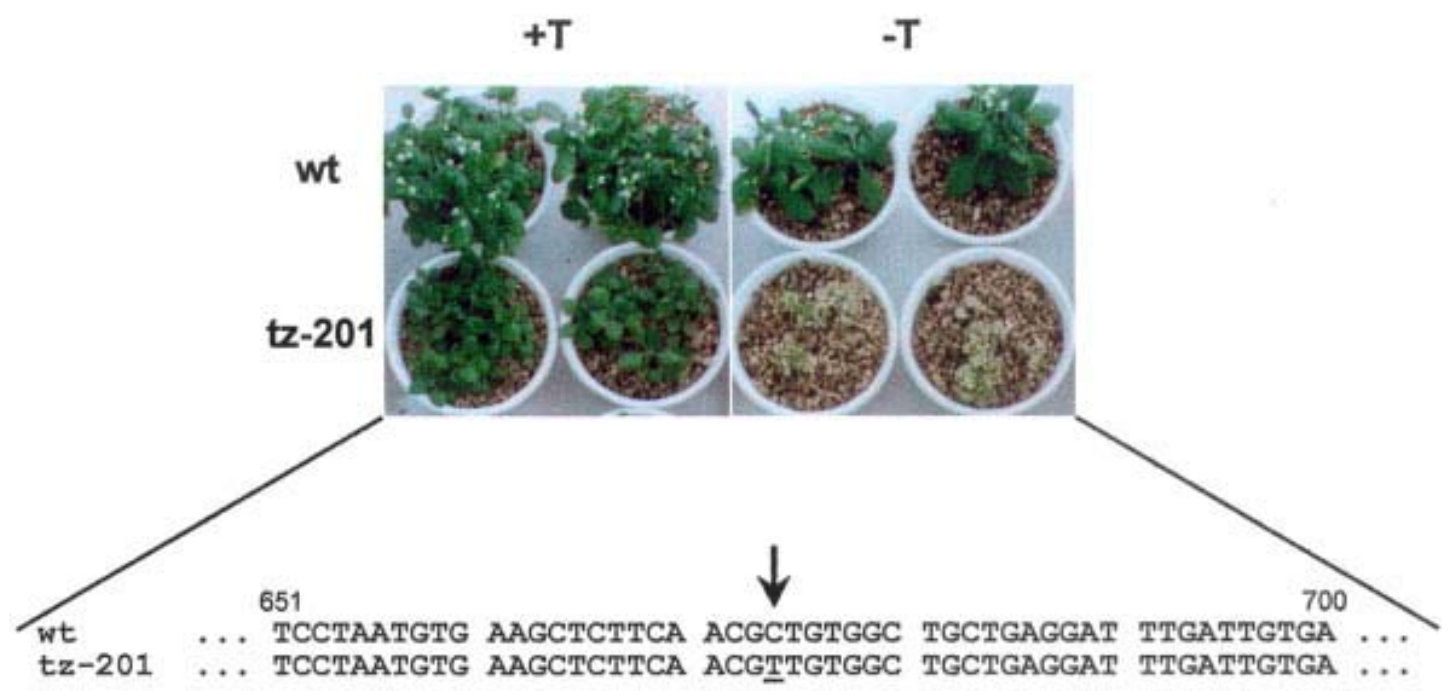

Figura 9: Análise comparativa de fenótipos entre plantas selvagem (Ler, wt) e mutante (tz-201) de Arabidopsis thaliana crescendo em meio suplementado (+T) ou não (-T) com tiamina. Sequência nucleotídica parcial do gene thi1 mostra a base alterada na linhagem mutante (seta) (PAPINI-TERZI et al. 2003).

RIBEIRO et al. (2005) fizeram a análise funcional da região promotora de thi1, realizada por meio da construção de uma série de cassetes da região promotora fusionada ao gene repórter GUS para determinar o padrão de expressão e a responsividade a diversas condições de estresse. Os resultados descritos anteriormente por PAPINI-TERZI et al. (2003) foram confirmados e, adicionalmente, verificou-se que a expressão é afetada por alta salinidade, falta de açúcar e estresse por alagamento. 
CHABREgAS et al (2001, 2003), confirmaram o duplo direcionamento de THI1 para mitocôndrias e cloroplastos por um mecanismo pós-traducional. O mRNA thi1 têm dois códons AUG em seqüência e a distribuição da proteína para as organelas em $A$. thaliana é determinada pelo uso diferencial dos códons de início de tradução (figura 10). O direcionamento de THI1 para mitocôndrias explica sua capacidade em complementar as leveduras mutantes THI4.

$\begin{array}{lcc}1^{\circ} \mathrm{ATG} & 2^{\circ} \mathrm{ATG} & \text { thi1 } \\ \text { (cloroplasto) } & \text { (mitocôndria) }\end{array}$

A)

B)

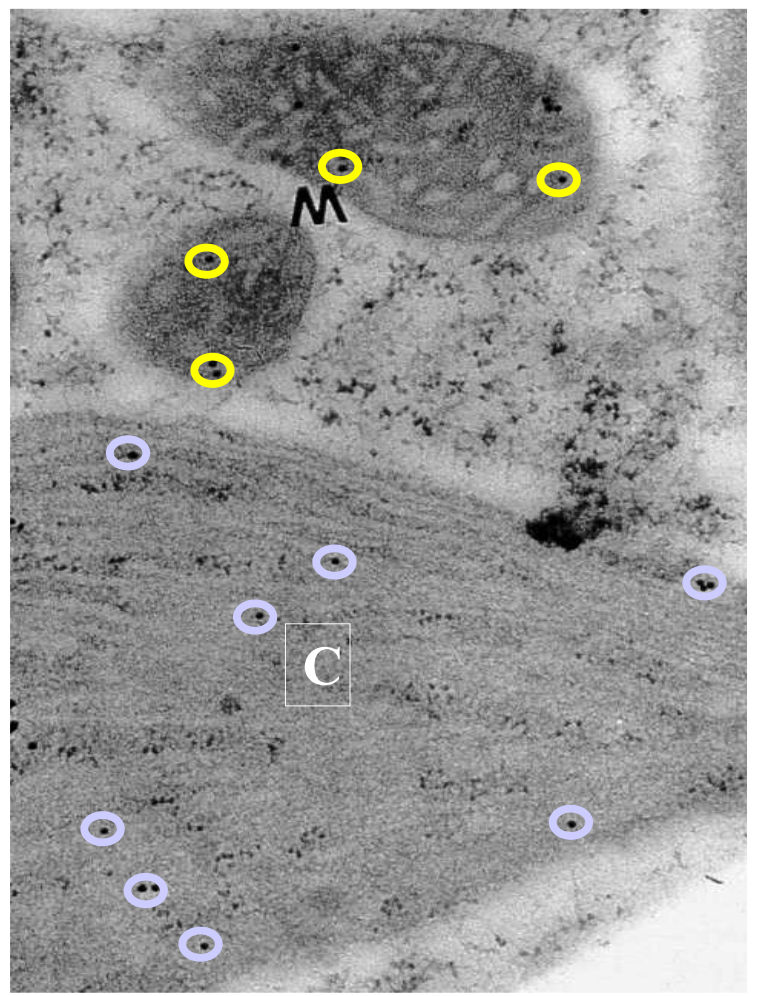

Figura 10: Direcionamento de THI1 para cloroplastos e mitocôndrias. A) representação esquemática da região N-terminal de thi1 de A. thaliana. AUG: sequência de início de tradução; B) Microscopia eletrônica de células de A. thaliana indicando a presença de THI1 nos cloroplastos (C) e mitocôndrias (M) (Modificado de CHABREGAS et al., 2001).

LUCHE (2002) verificou a capacidade de ligação de THI1 à molécula de DNA, entretanto descartou a hipótese de que esta proteína tivesse atividade de polimerase. 
GODOI et al (2006) e JURGENSON et al (2006), desvendaram a estrutura das proteínas THI1 e thi4, respectivamente. Ambos mostraram que estas proteínas estão organizadas na forma de um octâmero formado pela justaposição de dois tetrâmeros (figura 11). Esses originam uma estrutura "circular de duas camadas" que contém um poro ao longo de seu eixo longitudinal. O diâmetro do poro varia internamente, porém a menor medida é superior ao diâmetro de uma volta de DNA dupla fita. Esta observação sugere que THI1 possa se associar à molécula de DNA abrigando-a no interior do octâmero. Sabe-se que o genoma organelar apresenta-se associado a proteínas, algumas semelhantes a histonas. GODOI et al (2006) e JURGENSON et al (2006) descobriram, também, que há um precursor do tiazol, não descrito anteriormente, fortemente ligado à proteína purificada. Além disso, esta proteína se ligaria a NAD ao invés de FAD.

A)

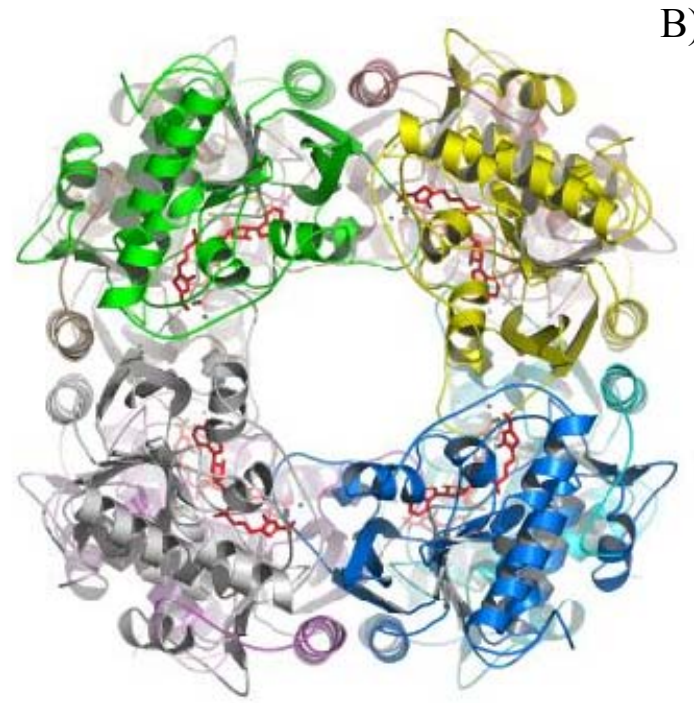

B)

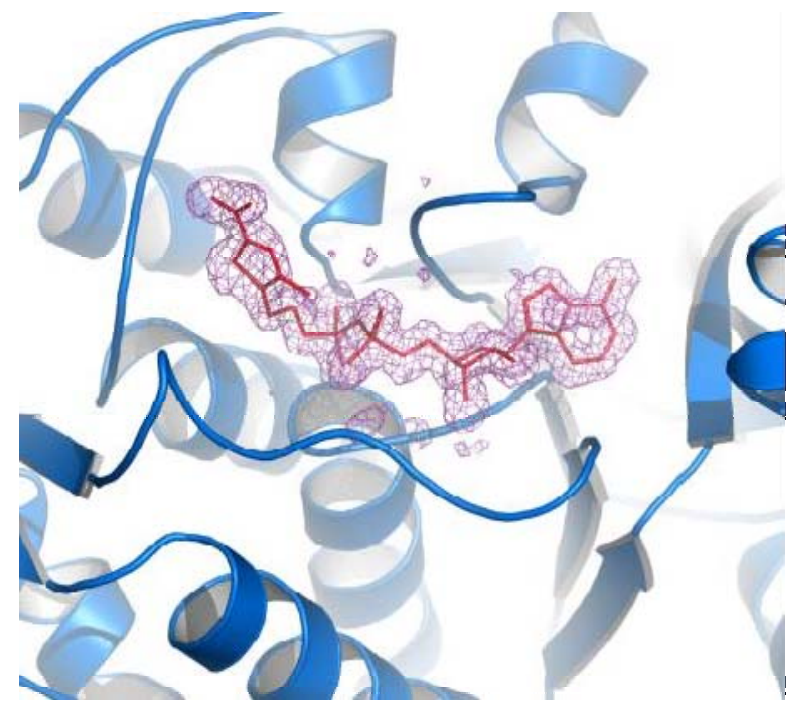

Figura 11: Estrutura protéica de THI1. A) Visualização do octâmero; B) Detalhe do

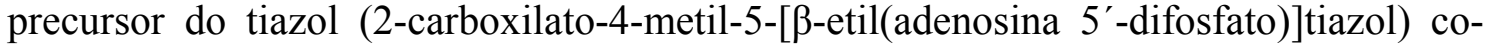
purificado com a proteína THI1 (GoDOI et al., 2006).

Em A. thaliana, o gene thi1 está envolvido na biossíntese de tiamina como descrito para thi4, o gene ortólogo em leveduras (PRAEKELT et al, 1994). Em plantas, a biossíntese de tiamina ocorre nos cloroplastos. Desta maneira, a isoforma da proteína THI1 direcionada aos cloroplastos seria responsável pela biossíntese da porção tiazólica 
Introdução 34

da tiamina, enquanto nas duas organelas seria responsável pela diminuição da quantidade de lesões no DNA. 


\section{Objetivos}

Hipótese - A proteína THI1 apresenta dupla função: síntese do anel de tiazol e envolvimento na tolerância a danos no DNA

Objetivo geral - Com base em trabalhos anteriores, o objetivo desse trabalho é contribuir na elucidação da função do gene thi1 de A. thaliana. Para tanto foram utilizadas linhagens de A. thaliana com diferentes constituições genéticas obtidas e/ou caracterizadas pelo grupo (PAPINI-TERZI et al, 2003; KASHIWABARA, 2003)

\section{Objetivos específicos:}

2.1. Modulação da expressão de thi1 em A. thaliana

2.1.1. Análise transcricional;

2.1.2. Análise traducional.

2.2. Análise de aspectos bioquímicos e fisiológicos associados ao gene thi1:

2.2.1. Análise de parâmetros biológicos como germinabilidade, massa fresca, partição de açúcares solúveis e dosagem de tiamina;

2.2.2. Investigação comparativa de metabolismo antioxidante;

2.2.3. Investigação comparativa do perfil protéico global;

2.2.4. Investigação comparativa de lesões no DNA de cloroplastos 


\section{Material e Métodos}

\subsection{Cultivo das Plantas}

\subsubsection{Material botânico}

Foram utilizadas linhagens selvagens de A. thaliana do ecótipo Landsberg erecta (Ler), linhagens mutantes (tz-201) auxotróficas à tiamina, em que ocorre a substituição do aminoácido alanina por valina na posição 184 (PAPINI-TERZI et al, 2003), e linhagens transgênicas thi $1_{s} a$ e thi $1_{a s} a$ contendo o cDNA-thi1 exógeno nas orientações senso e antisenso, respectivamente (KASHIWABARA, 2003).

Foram utilizadas, também, plantas do ecótipo Ler transformadas com um plasmídeo portando o fragmento do promotor thi1 da posição -16 à -608 (Pthi608) em relação ao sitio de início de tradução (RIBEIRO et al, 2005), fusionado ao gene repórter $\beta$-glucuronidase (GUS). Como controle positivo, foram utilizadas plantas contendo o promotor do CaMV 35S fusionado a GUS, e como controle negativo uma planta selvagem.

\subsubsection{Condições utilizadas}

As diferentes linhagens de A. thaliana foram cultivadas na terra e in vitro em salas de cultura à temperatura de $23^{\circ} \mathrm{C}$ durante o dia e $19^{\circ} \mathrm{C}$ durante a noite, sob fotoperíodo de $12 \mathrm{~h}$. As plantas utilizadas nos experimentos de ritmo circadiano foram submetidas a fotoperíodo de 16h, sob as mesmas condições de temperatura relatadas anteriormente. Sempre foram coletadas plantas de 18 dias, as $10 \mathrm{am}$, com exceção daquelas utilizadas nos ensaios histoquímicos e na modulação de expressão de RNAm thi1 e da proteína THI1 ao longo do dia, coletadas em horários que serão descriminados nos itens específicos a esses experimentos.

Para a produção de sementes, as plantas foram cultivadas na terra em substrato composto de terra não adubada e vermiculita (1:1). As plantas foram irrigadas com 
solução nutritiva (item 3.1.2.1) uma vez por semana e água, também uma vez por semana. Aos vasos das plantas mutantes (tz-201) foram adicionadas, uma vez por semana, gotas de solução de tiamina $0,1 \%$ (w/v) (Sigma), esta preparada com água destilada e mantida a $4^{\circ} \mathrm{C}$. Após a coleta das sementes, essas foram secas ao ar, em sala de cultura, peneiradas e, em seguida, armazenadas em microtubos de 1,5 mL e mantidas à temperatura ambiente. Para o cultivo in vitro, todo o procedimento foi feito em câmara de fluxo laminar com material estéril inclusive a desinfestação das sementes.

Desinfestação das sementes: As sementes são colocadas em microtubos e é adicionada uma solução de cândida comercial pura (hipoclorito de sódio 2,5 - 3 \%) e 0,1\% de Tween 20 durante 7 minutos. Após esse período, as sementes são enxaguadas com água destilada estéril (autoclavada a $120^{\circ} \mathrm{C}, 1 \mathrm{~atm}, 15$ minutos) e semeadas em placas de Petri contendo MS 1/2 20 sólido (item 3.1.2.2).

\subsubsection{Solução nutritiva e meios de cultura}

\subsubsection{Solução nutritiva}

Para o preparo da solução nutritiva, foram feitas, inicialmente, soluções estoque $1 \mathrm{M}$ dos nutrientes citados abaixo com água destilada, sendo estas esserilizadas em autoclave $\left(120^{\circ} \mathrm{C}, 1 \mathrm{~atm}, 15\right.$ minutos $)$ e armazenadas a $4^{\circ} \mathrm{C}$.

Solução nutritiva 2x: $\left(\mathrm{Ca}\left(\mathrm{NO}_{3}\right)_{2} 5 \mathrm{mM}(5 \mathrm{~mL} / \mathrm{L}\right.$ da sol. $1 \mathrm{M}) ; \mathrm{KNO}_{3} 5 \mathrm{mM}(5 \mathrm{~mL} / \mathrm{L}$ da sol. $1 \mathrm{M}) ; \mathrm{MgSO}_{4} 2 \mathrm{mM}(2 \mathrm{~mL} / \mathrm{L}$ da sol. $1 \mathrm{M}) ; \mathrm{KH}_{2} \mathrm{PO}_{4} 1 \mathrm{mM}(1 \mathrm{~mL} / \mathrm{L}$ da sol. $1 \mathrm{M})$; FeEDTA 1mM (*) (10 mL/L da sol. 0,1M); Micronutrientes (**) - 1,2 mL/L). A solução nutritiva $2 \mathrm{x}$ foi armazenada à temperatura ambiente em frascos escuros e, no momento do uso, foi diluída com água destilada para concentração final 1x.

(*) FeEDTA (armazenado em frasco escuro, protegido da luz):

$\mathrm{Na}_{2} \mathrm{EDTA}-7,44 \mathrm{~g} / \mathrm{L} ; \mathrm{FeSO}_{4} \cdot 7 \mathrm{H}_{2} \mathrm{O}-5,57 \mathrm{~g} / \mathrm{L}$ 
$(* *)$ Micronutrientes:

$\mathrm{H}_{3} \mathrm{BO}_{3}-2,86 \mathrm{~g} / \mathrm{L}(46 \mathrm{mM}) ; \mathrm{MnCl}_{2} \cdot 4 \mathrm{H}_{2} \mathrm{O}-1,81 \mathrm{~g} / \mathrm{L}(9,14 \mathrm{mM}) ; \mathrm{ZnCl}_{2}-1,10$

$\mathrm{g} / \mathrm{L}(1 \mathrm{mM}) ; \mathrm{CuCl}_{2}-0,05 \mathrm{~g} / \mathrm{L}(0,29 \mathrm{mM}) ; \mathrm{NaMoO}_{4} \cdot 2 \mathrm{H}_{2} \mathrm{O}-0,025 \mathrm{~g} / \mathrm{L}(0,1 \mathrm{mM})$.

\subsubsection{Meio de cultura}

Como meio de cultura foi utilizado o MS $1 / 220$. O pH foi medido sem a adição do Phytagar (Gibco BRL). Após a adição desse, a solução foi esserilizada em autoclave $\left(120^{\circ} \mathrm{C}, 1 \mathrm{~atm}, 15\right.$ minutos $)$ e armazenada a $4^{\circ} \mathrm{C}$. Para o meio de cultura líquido, não foi adicionado Phytagar no MS 1/2 20; para o meio sem sacarose não houve a adição desse açúcar no "MS 1/2 20"; e para o meio de cultura sem tiamina, foi preparada uma solução de vitaminas de Nitsch 500x sem tiamina. A solução de vitaminas de Nitsch deve ser preparada com água ultrafiltrada previamente esserilizada em autoclave $\left(120^{\circ} \mathrm{C}, 1 \mathrm{~atm}\right.$, 30 minutos) e armazenada a $20^{\circ} \mathrm{C}$ negativos.

Meio MS 1/2 20 (Murashige \& SKOOG, 1962, modificado):

Solução de macronutrientes 10x (Sigma) - 100mL/L; Solução de micronutrientes 10x (Sigma) - 100mL/L; Vitaminas MS (Sigma) - 1mL/L; Sacarose (Merck) - 20 g/L; pH 5,7 com KOH 1M. Para meio sólido: 5,8 g Phytagar (Gibco BRL) $\underline{\text { Vitaminas de Nitsch (500x): }}$

Mioinositol - $50 \mathrm{mg} / \mathrm{mL} ; \quad$ Glicina $-1 \mathrm{mg} / \mathrm{mL}$; Ácido nicotínico - 2,5mg/mL; Piridoxina $-0,25 \mathrm{mg} / \mathrm{mL}$; Tiamina $-0,25 \mathrm{mg} / \mathrm{mL}$; Ácido fólico $-0,25 \mathrm{mg} / \mathrm{mL}$; Biotina $0,025 \mathrm{mg} / \mathrm{mL}$

\subsection{Modulação da expressão do gene thi1 em A. thaliana}

\subsubsection{Análise do promotor thi1}

\subsubsection{Tratamento das plantas}


Foi analisada a expressão do gene thi1 em diferentes tecidos de plantas crescidas em meio com sacarose (MS 1/2 20) e sem sacarose, e coletadas em diferentes horários do dia, utilizando-se plantas que possuem um plamídeo contendo o promotor thi1 fusionado ao gene GUS, já descritas anteriormente (item 3.1.1.). Foram coletadas plantas de 18 dias, em diferentes horários (9 a.m., 12 a.m., 3 p.m., 6 p.m., 9 p.m.). O gene uidA, que codifica para a enzima $\beta$-glucuronidase (GUS), é amplamente utilizado como gene repórter em plantas. A atividade de GUS pode ser detectada nos tecidos por ensaios histoquímicos. A enzima cliva o substrato não colorido X-GLUC em um indoxil intermediário que é, posteriormente, dimerizado, e precipita com uma coloração azul (JEFFERSON et al., 1987).

\subsubsection{Preparação do material}

Inicialmente, as plantas coletadas foram colocadas em acetona $90 \%$ gelada e mantidas nesta solução por 20 minutos. Em seguida foram lavadas em tampão de coloração gelado (triton $0,2 \%, \mathrm{NaPO} 450 \mathrm{mM} \mathrm{pH} \mathrm{7,2,} \mathrm{ferrocianeto} 2 \mathrm{mM}$, ferricianeto 2mM, X-GLUC $2 \mathrm{mM}$ e água para completar) sem X-GLUC, e na seqüência com o mesmo tampão adicionando-se o substrato. As plantas, então, imersas nesta solução, foram submetidas a vácuo $(300 \mathrm{mmHg})$ por 10 minutos para que ocorresse a penetração do X-GLUC em seus tecidos. Posteriormente as amostras foram mantidas a $37^{\circ} \mathrm{C}$ por 24 horas, protegidas da luz.

Para fixação da coloração azul, as plantas foram desidratadas utilizando-se diferentes concentrações de etanol na seguinte seqüência: etanol 20\%, 35\%, 50\% e 70\%. A duração de cada desidratação foi de 30 minutos, à temperatura ambiente, com leve agitação. Posteriormente, para manter os tecidos íntegros, as plantas foram submetidas a paraformaldeído $4 \%$ à temperatura ambiente por 30 minutos, com leve agitação. Na seqüência, as plantas foram analisadas. 
O ferrocianeto e ferricianeto foram preparados em água e mantidos no escuro a $4^{\circ} \mathrm{C}$, e o X-GLUC foi preparado em dimetil formamida e mantido no escuro a $-20^{\circ} \mathrm{C}$.

\subsubsection{Análise das plantas}

Para a análise das plantas foi utilizada uma lupa Nikon SMZ800, uma máquina fotográfica Nikon Collpix4300, e uma fonte de luz de fibra óptica Nikon. Para calcular as escalas de cada foto, foi feita a razão entre o diâmetro real do círculo onde as amostras foram fotografadas e o diâmetro do mesmo círculo nas condições utilizadas para fotografar cada amostra. Desta maneira, foi possível estimar quantas vezes a amostra foi amplificada pela lupa e pelo “zoom” da máquina.

\subsubsection{Análise transcricional}

\subsubsection{Condições experimentais}

\subsection{Comparação de expressão de RNAm thi1 entre as linhagens} selvagem, mutante e transgênicas

Foram utilizadas as linhagens selvagem (Ler), mutante (tz-201), senso (thi1 $\left.1_{s} a\right)$ e antisenso (thi $\left.1_{a s} a\right)$ de A. thaliana, com 18 dias e coletadas as 10 a.m..

\subsection{Análise de expressão de RNAm thi1 ao longo do dia}

Foram utilizadas plantas da linhagem selvagem (Ler) de $A$. thaliana crescidas por 18 dias. Inicialmente, foram analisadas plantas coletadas as 9am, 12am, 3pm, $6 \mathrm{pm}$ e 9pm e, subseqüentemente, plantas (de 16 a 18 dias) crescidas em fotoperíodo $16 \mathrm{~h}$ (CE, claro/escuro) ou submetidas a claro total (CC, claro/claro) por 72 horas, e coletadas de 3 em 3 horas, para verificar se o gene thi1 estaria sob influência circadiana. Plantas foram submetidas a claro total $21 \mathrm{~h}$ antes da primeira coleta, para que ocorresse a aclimatação das mesmas. No período de dia $(8 \mathrm{am}-12 \mathrm{pm})$, as plantas foram submetidas à temperatura de $22^{\circ} \mathrm{C}$, enquanto à noite $(12 \mathrm{pm}-8 \mathrm{am})$, as plantas foram submetidas à temperatura de $19^{\circ} \mathrm{C}$. 
3.2.2.1.3. Análise da expressão de RNAm thi1 em plantas crescidas na ausência de sacarose ou sob hipoxia

Foram utilizadas plantas das linhagens selvagem (Ler) e mutante (tz-201) crescidas por 18 dias em meio sem sacarose e plantas crescidas sob hipoxia. Como controle para as duas condições, foram utilizadas plantas crescidas em meio sólido contendo 20 g.L $\mathrm{L}^{-1}$ de sacarose por 18 dias. Para a condição de hipoxia, plantas foram crescidas em meio sólido por 14 dias e então transferidas para meio líquido por 4 dias (SL, sólido/líquido); outro grupo de plantas foi crescido em meio sólido por 14 dias, transferido para meio líquido por 2 dias e então transferido para meio sólido por 2 dias (SLS, sólido/líquido/sólido). Na condição sem sacarose, as plantas foram crescidas em meio sem sacarose por 18 dias.

\subsubsection{Extração do RNA total}

Para a extração de RNA, foram utilizadas plantas inteiras, pesando de 50100mg, que foram maceradas em nitrogênio líquido até produzir pó fino. Em seguida, foi realizada a extração de RNA total com a utilização do reagente TRIZOL (Gibco BRL), de acordo com as especificações do fabricante. O rendimento dessa extração é em torno de $1000 \mathrm{ng} / \mathrm{uL}$.

A extração e manipulação de RNA exigem um preparo diferenciado de todo o material, assim como de todas as soluções a serem utilizadas. Toda a água (ultrafiltrada) empregada no preparo de soluções, na lavagem de material e no processo de extração deve ser coletada no momento do uso ou, sempre que possível, ser submetida ao tratamento com dietil pirocarbonato (DEPC). A vidraria utilizada deve ser tratada com clorofórmio, enxaguada e submetida à esserilização em autoclave $\left(120^{\circ} \mathrm{C}, 30\right.$ minutos $)$. Utilizamos pipetas e ponteiras descartáveis com filtro e todo o procedimento foi feito com luvas. Cubas de eletroforese, pentes, suportes para o preparo do gel e bandejas de 
transferência de RNA foram tratadas com NAOH 0,2 N (ou com detergente) por, pelo menos, 24 horas antes de serem enxaguados para o uso.

Água DEPC: a água ultrafiltrada é mantida a $37^{\circ} \mathrm{C}$ por $16 \mathrm{~h}$ na presença de $0,01 \%$ de DEPC (Sigma) e, então, é submetida à esserilização em autoclave $\left(120^{\circ} \mathrm{C}, 30\right.$ minutos). O tratamento visa eliminar eventuais moléculas de RNAse.

\subsubsection{Preparação do RNA}

Após a extração do RNA total, as amostras foram tratadas com DNase I (Ambion, AM1907), conforme as especificações do fabricante, para eliminar possível contaminação de DNA. Para tanto foi utilizada $2 \mathrm{U}$ de enzima para cada ug de RNA. É recomendável a utilização da DNase referente ao número de catálogo AM1907, pois nesse kit, juntamente com a enzima, vem o reagente de inativação da DNase, não sendo necessário, portanto, o posterior tratamento das amostras com fenol-clorofórmio, o que costuma diminuir muito o rendimento do RNA. Mesmo tratando as amostras com DNase I (Ambion, AM1907), o rendimento diminui para 500ng/uL.

Em seguida, as amostras tratadas (controle negativo) e amostras de DNA de boa qualidade (controle positivo) foram submetidas à PCR utilizando os iniciadores do gene constitutivo UBQ14 (item 3.2.2.4., tabela 2) para confirmar que não haveria nenhuma molécula de DNA presente nas amostras. Após a reação de PCR (*), foram feitos géis de agarose $0,8 \%$ médios em TBE $1 / 2 \times$ onde foram aplicados $25 \mathrm{uL}$ do produto de PCR e corridos a 30 mA. Se as amostras não apresentassem contaminação com DNA, seguiase para o próximo passo que é a síntese da 1fita.

Para a síntese da $1^{\text {a }}$ fita de cDNA foi utilizado o kit "SuperScript III First strand" (Invitrogen), conforme especificações do fabricante, partindo-se de, no mínimo, 1,5 ug do RNA purificado anteriormente. 


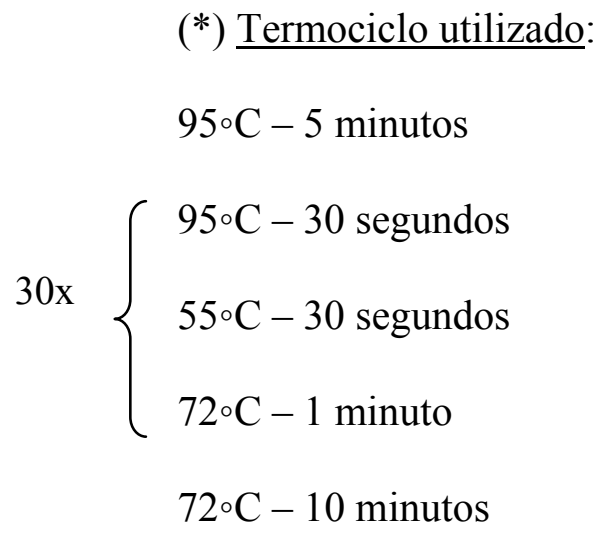

\subsubsection{Iniciadores utilizados}

Foi utilizado um par de iniciadores para amplificar um fragmento do gene thi1, e outro par de iniciadores para amplificar um fragmento gene constitutivo UBQ14 (Poliubiquitina14) (tabela 2).

Tabela 2: Iniciadores utilizados na RT-qPCR e suas características

\begin{tabular}{clccc}
\hline $\begin{array}{c}\text { Nome } \\
\text { iniciador }\end{array}$ & \multicolumn{1}{c}{ Sequência (5' a 3') } & $\begin{array}{c}\text { Tamanho } \\
(\mathbf{p b})\end{array}$ & $\begin{array}{c}\text { Tm } \\
\left({ }^{\circ} \mathbf{C}\right)\end{array}$ & $\begin{array}{c}\text { DNA } \\
\text { amplificado }\end{array}$ \\
\hline RTthi1R & GCA AGT TGT CCC GCC TTT TG & 75 & 65 & Nuclear \\
RTthilL & GAT CGA TGG TGC ACC GAG AA & & 65 & \\
UBQ14F & TCA CTG GAA AGA CCA TTA CTC TTG AA & 127 & 62 & Nuclear \\
UBQ14R & AGC TGT TTT CCA GCG AAG ATG & & 62 & \\
\hline
\end{tabular}

\subsubsection{Condições utilizadas na RT-qPCR}

A reação de PCR foi montada da seguinte maneira:

6,25 uL mix iniciadores (forward e reverse, ambos a 3,6 mM)

6,25 uL cDNA (diluído 10x)

\section{2,50 uL SYBR Green (Applied Biosystems)}

Como controle negativo para esta reação foi utilizada água autoclavada ao invés de cDNA. As reações foram montadas em fluxo laminar, sob condições estéreis.

Termociclo utilizado:

$95^{\circ} \mathrm{C}-10$ minutos

$40 \mathrm{x}\left\{\begin{array}{l}95^{\circ} \mathrm{C}-15 \text { segundos } \\ 55^{\circ} \mathrm{C}-1 \text { minuto (temperatura única para anelamento e extensão) }\end{array}\right.$ 
Ciclo de $\begin{aligned} & 95{ }^{\circ} \mathrm{C}-15 \text { segundos } \\ & 60{ }^{\circ} \mathrm{C}-30 \text { segundos } \\ & 95{ }^{\circ} \mathrm{C}-15 \text { segundos }\end{aligned}$

\subsubsection{Análise dos resultados}

Os dados de RT-qPCR foram analisados segundo o método $2^{-\Delta C T}$ (LIVAK \& SchmitTGEN, 2001). Os dados são mostrados como valores relativos, já que esses se referem à expressão de thi1 nas diferentes amostras em relação à expressão do gene constitutivo UBQ14. Foram realizados dois experimentos independentes.

\subsubsection{Análise traducional}

\subsubsection{Condições experimentais}

3.2.3.1.1. Comparação dos níveis da proteína THI1 entre as linhagens selvagem, mutante e transgênicas

Foram utilizados, aproximadamente, $2 \mathrm{~g}$ de plantas inteiras das linhagens selvagem (Ler), mutante (tz-201), senso (thi $\left.1_{s} a\right)$ e antisenso (thi $\left.1_{a s} a\right)$ de A. thaliana, com 18 dias e coletadas as 10 a.m..

\subsection{Análise dos níveis da proteína THI1 ao longo do dia}

Foram utilizados, aproximadamente, 150mg de plantas inteiras da linhagem selvagem (Ler) de A. thaliana crescidas por 18 dias e coletadas as 9am, 12am, 3pm, 6 pm e $9 \mathrm{pm}$.

Em ambos os experimentos (itens 3.2.3.1.1 e 3.2.3.1.2), foram utilizados como controle positivo a proteína THI1 recombinante purificada (LUCHE, 2002) e como controle negativo a proteína At-XPB 1 recombinante purificada (MORGANTE, 2002). Foi aplicado $1 \mu \mathrm{g}$ de cada extrato e $0,01 \mu \mathrm{g}$ das amostras purificadas. Para quantificar THI1 no extrato protéico total, foram aplicadas na membrana alíquotas da proteína THI1 purificada $(0,0125 \mu \mathrm{g}, 0,025 \mu \mathrm{g}$ e $0,05 \mu \mathrm{g})$, a fim de obter uma curva padrão relacionando 
concentração da proteína pura e densitometria. Com os resultados de densitometria dos extratos, foi possível inferir sobre a quantidade da proteína THI1 presente em cada amostra.

\subsubsection{Extração de proteínas}

As folhas congeladas foram trituradas em nitrogênio líquido, juntamente com pó de vidro. Em seguida, foram adicionados 2,5 volumes (em $\mathrm{mL}$ em relação à massa inicial em gramas) de tampão de extração e esta solução foi submetida à centrifugação a $10.500 \mathrm{rpm}$ por 5 minutos a $4^{\circ} \mathrm{C}$ (Centrífuga Sorvall, rotor SS34). Extratos das frações solúveis das diferentes linhagens de $A$. thaliana foram filtradas em filtro para seringa 0,45 $\mu \mathrm{M}$ (Millipore) e, após esse procedimento, foi feita a quantificação de proteínas pelo método de BRADFORD (1976), utilizando ovoalbumina como padrão.

Os extratos protéicos foram, então, submetidos a slot blot. As amostras foram aplicadas (sem serem submetidas à fervura), em duplicata, sobre uma membrana de nitrocelulose, previamente equilibrada em tampão Tris-Glicina $1 \mathrm{X}$ acrescido de $10 \%$ (v/v) de metanol por 15 minutos. Para o slot blot utilizou-se um aparato (HYBRISLOT $^{\mathrm{TM}}$ Manifold, Life Technologies) que possui poços com áreas iguais para aplicação das diferentes amostras. Após aplicação das amostras, a membrana foi colocada em solução de, à temperatura ambiente, por cerca de 24 horas. Terminado o bloqueio, a membrana foi acondicionada em saco plástico e incubada com o anticorpo primário, policlonal anti-THI1 $(130 \mathrm{ug} / \mathrm{mL}$, diluição 1:500 em leite desnatado 5\%, Chabregas et al. 2001) por 2 horas, a $4^{\circ} \mathrm{C}$. A membrana foi, então, lavada três vezes, por dez minutos cada, com tampão TBS 1 X / Tween 20 0,1 \% e seguiu-se a incubação com o anticorpo secundário (anti-mouse IgG peroxidase, Sigma), na diluição de 1:2000 (com leite desnatado $5 \%$ ), por 1 hora a $4^{\circ} \mathrm{C}$. Seguiram-se três lavagens com tampão TBS $1 \mathrm{X} /$ Tween $200,1 \%$, por dez minutos cada. 
A revelação foi realizada em sala escura utilizando-se o sistema de detecção "ECL Wessern blotting detection reagent" (Amersham Pharmacia Biotech, RPN 2106), conforme especificações do fabricante. Em seguida, o filme de raio X (IBF-Medix RXV) foi exposto à luminescência, à temperatura ambiente, por 5 minutos. A quantificação das bandas foi determinada por densitometria usando "1D Image Analysis Software" (Kodak Digital Science). Foram realizados dois experimentos independentes.

Tampão de extração:

Tris $0,1 \mathrm{M} \mathrm{pH} \mathrm{7,6} \mathrm{e} \mathrm{ácido} \mathrm{ascórbico} \mathrm{0,1 \%}$

$\underline{\text { Tampão Tris-Glicina } 1 \mathrm{X}}$ :

Tris $25 \mathrm{mM}$; Glicina $250 \mathrm{mM}$ pH 8,3; SDS $0,1 \%(\mathrm{v} / \mathrm{v})$

\section{TBS 1X:}

TRIS 2,42 g/L; $\mathrm{NaCl} 8$ g/L pH 7,5

Solução de bloqueio:

TBS 1 X; Tween 0,05\%; Leite Molico desnatado $5 \%$

\subsection{Aspectos bioquímicos e fisiológicos associados ao gene thi1}

\subsubsection{Taxa de germinação de sementes}

Para se determinar a taxa de germinação de sementes das linhagens selvagem (Ler), mutante (tz-201), senso (thi $\left.1_{s} a\right)$ e antisenso (thi $\left.1_{a s} a\right)$ de A. thaliana foram utilizadas 100 sementes de cada linhagem e, especificamente, sementes da geração $T_{3}$ das linhagens transgênicas, todas crescidas ao mesmo tempo sob as mesmas condições. Essas foram semeadas em meio MS 1/2 20 após desinfestação. Depois de 7 dias, foi contado o número de sementes a partir das quais havia emergido os cotilédones (sementes viáveis). Esse experimento foi realizado com sementes armazenadas por 3, 6 e 9 meses e sementes sem armazenar (0). A taxa de germinação foi calculada 
considerando-se o número de sementes germinadas $(\mathrm{G})$ em relação ao total de sementes (T). Taxa de germinação é igual a $\mathrm{G} / \mathrm{T}$, em porcentagem.

\subsubsection{Massa fresca}

Para a determinação de massa fresca das diferentes linhagens de A. thaliana, houve semeadura, após desinfestação das sementes, em meio MS 1/2 20. Foram utilizados 15 indivíduos de cada linhagem por ponto de medida. Plantas com 3, 4, 5 e 6 semanas após a germinação, foram coletadas e tiveram suas massas medidas utilizandose uma balança de precisão (4 casas). Foram medidas as massas dos indivíduos inteiros e, posteriormente, do caule e raiz separadamente, obtendo-se os valores de desvio em todos os casos.

\subsubsection{Carboidratos de baixo peso molecular}

A análise de carboidratos de baixo peso molecular foi feita em colaboração com o Prof. Dr. Marcos Silveira Buckeridge (Universidade de São Paulo, IB) e com o pesquisador Marco Tiné (Instituto Botânico). A quantificação de carboidratos foi baseada no método de ROESSNER et al (2001), feita por CG-MS (gas chromatographymass spectrometry).

\subsubsection{Extração de carboidratos de baixo peso molecular}

Plantas de 18 dias das linhagens selvagem (Ler), mutante (tz-201), senso (thi $1_{s} a$ ) e antisenso (thi $1_{a s} a$ ) (aproximadamente $20 \mathrm{mg}$ de plantas secas) foram coletadas as 10a.m. e os carboidratos extraídos em $500 \mu \mathrm{L}$ de uma mistura metanol:clorofórmio:água (12:5:3, respectivamente) contendo $200 \mu \mathrm{g}$ de phenyl- $\beta$-D-glucopyranoside como padrão interno. Esta solução foi mantida por 30 minutos a $60^{\circ} \mathrm{C}$, misturada vigorosamente em 1 volume de água, centrifugada a $10.000 \mathrm{~g}$ por 2 minutos. A fase superior foi coletada e subseqüentemente seca a vácuo. O resíduo foi re-dissolvido e derivatizado por adição de $200 \mu \mathrm{L}$ de piridina seguida por $25 \mu \mathrm{L}$ de uma mistura N,O- 
bis-(trimethylsilyl)-trifluoroacetamide (BSTFA):trimethyl-chlorosilane (TMCS) (10:1, respectivamente). Esta solução foi submetida a $70^{\circ} \mathrm{C}$ por 60 minutos. $10,30,50$ e $70 \mu \mathrm{L}$ de uma mistura de soluções padrões de todos os carboidratos relevantes $(1 \mathrm{mg} / \mathrm{L}$ em água) foi adicionado a 70, 50, 30 e $10 \mu \mathrm{L}$, respectivamente, de uma solução phenyl- $\beta$-Dglucopyranoside $(1 \mathrm{mg} / \mathrm{mL})$. Os padrões foram, então, derivatizados. Foram injetados $0,5 \mu \mathrm{L}$ das amostras e dos padrões.

\subsubsection{Condições cromatográficas}

O sistema CG-MS é composto de um AS 2000 autosampler, um cromatógrafo de gás GC 8000, e um espectrômetro de massa quadrupolo Voyager (ThermoQuest, Manchesser, UK). O espectrômetro de massa foi estabilizado de acordo com recomendações de fabricante. GC foi realizada com uma coluna 30-m SPB-50 with 0.25- $\mu \mathrm{m}$ de espessura (Supelco, Bellfonte, CA). A temperatura de injeção foi de $230{ }^{\circ} \mathrm{C}$, a interface a $250{ }^{\circ} \mathrm{C}$, e a fonte de íons ajustada a $200{ }^{\circ} \mathrm{C}$. Hélio foi usado em um fluxo de $1 \mathrm{~mL} / \mathrm{min}$. A análise foi realizada sob o seguinte programa de temperatura: $5 \mathrm{~min}$ de aquecimento isotérmico a $70^{\circ} \mathrm{C}$, seguido por aumento de $5{ }^{\circ} \mathrm{C} / \mathrm{min}$ da temperatura do forno até $310{ }^{\circ} \mathrm{C}$, e $1 \mathrm{~min}$ de aquecimento na temperatura de $310^{\circ} \mathrm{C}$. O sistema foi, então, equilibrado por 6 minutos a $70{ }^{\circ} \mathrm{C}$ antes da injeção da próxima amostra. $\mathrm{O}$ espectro de massa foi lido a 2 scan/sec com uma taxa de "scanning" de 50 to $600 \mathrm{~m} / \mathrm{z}$. Tanto os cromatogramas quanto os espectros de massa foram avaliados usando o programa MASSLAB (ThermoQuest). Tempo de retenção e uma biblioteca de espectros de massa para quantificação automática de metabólitos foram implementados nesse programa. Substâncias foram identificadas por comparação com padrões, como descrito por ROESSNER et al (2000). Para quantificar os metabólitos de modo que ficassem comparativos entre si, todos os dados foram corrigidos pelo fator interno.

\subsubsection{Antioxidantes}




\subsubsection{Enzimas antioxidantes}

\subsection{Tratamento das plantas}

\subsection{Claro / Escuro}

Para verificar a influência da luz na produção de SOD, CAT, APX e GPX (glutationa peroxidase), as linhagens selvagem (Ler) e mutante (tz-201) foram divididas em 3 lotes. Após um período de 14 dias de crescimento em fotoperíodo 12 horas, 2 lotes de cada linhagem foram transferidos para o escuro por 48 horas. Um desses lotes retornou às condições usuais de luminosidade por mais 48 horas (CEC, claro/escuro/claro), enquanto o outro lote permaneceu no escuro por mais 48 horas (CE, claro/escuro). $\mathrm{O}$ terceiro lote foi mantido em fotoperíodo 12 horas durante todo $\mathrm{o}$ período de crescimento $(\mathrm{C}$, controle). Plantas inteiras de 18 dias foram coletadas as 10a.m, submetidas ao processo de extração de enzimas antioxidantes congelando-se, posteriormente, os extratos a $-80^{\circ} \mathrm{C}$.

\subsection{Alagamento}

Para verificar a influência da hipoxia (alagamento) na produção de SOD, CAT, APX e GPX, as linhagens selvagem (Ler) e mutante (tz-201) foram divididas em 3 lotes. Após um período de 14 dias de crescimento em meio sólido MS $1 / 220$ sob fotoperíodo 12 horas, 2 lotes de cada linhagem foram transferidos para placas de cultura de células de 24 poços, contendo $300 \mathrm{uL}$ de meio MS 1⁄2 20 líquido (mantendo apenas as raízes submersas) por 48 horas, sendo uma plântula depositada em cada orifício. Um desses lotes retornou ao meio sólido por mais 48 horas (SLS, sólido/líquido/sólido), enquanto o outro permaneceu em condição de alagamento por mais 48 horas (SL, sólido/líquido). O terceiro lote foi mantido em meio sólido durante todo o período de crescimento (C, controle). Plantas inteiras de 18 dias foram coletadas as 10a.m., 
submetidas ao processo de extração de enzimas antioxidantes congelando-se, posteriormente, os extratos a $80^{\circ} \mathrm{C}$ negativos.

\subsection{Crescimento em meio sem sacarose}

Para analisar os efeitos da ausência de sacarose durante o crescimento das plantas, as linhagens selvagem (Ler) e mutante (tz-201) foram crescidas em meio sem sacarose por 18 dias (Sem sacarose) e um lote de plantas foi mantido em meio sólido contendo 20 g. $\mathrm{L}^{-1}$ de sacarose (MS $1 / 2$ 20) como controle (C, controle). Plantas inteiras com 18 dias foram coletadas as 10a.m., submetidas ao processo de extração de enzimas antioxidantes congelando-se, posteriormente, os extratos a $80^{\circ} \mathrm{C}$ negativos. Esses foram utilizados para verificar a atividade de SOD, CAT, APX e GPX.

\subsection{Extração de enzimas antioxidantes}

A extração das enzimas antioxidantes foi feita segundo RAO et al (1996). Plantas inteiras de 18 dias das linhagens selvagem (Ler) e mutante (tz-201) de A. thaliana foram trituradas em nitrogênio líquido com $100 \mathrm{mg}$ de PVPP e pó de vidro. Esse foi ressuspendido em tampão de extração a $4^{\circ} \mathrm{C}$. As amostras foram filtradas através de um filtro de $0,45 \mu \mathrm{M}$ (Millipore) e centrifugadas a $13.000 \mathrm{rpm}$ por 20 minutos a $4^{\circ} \mathrm{C}$ (Centrífuga Sorvall, rotor SS34). O conteúdo de proteínas do sobrenadante foi concentrado por precipitação com sulfato de amônio. Inicialmente foi preparada uma solução saturada (100\%) desse sal. O sobrenadante foi diluído com solução de sulfato de amônio $100 \%$ até chegar a uma solução de sulfato de amônio 45\%. Esta foi incubada no gelo por 30 minutos e centrifugada a $10.500 \mathrm{rpm}$ por 10 minutos a $4^{\circ} \mathrm{C}($ Centrífuga Sorvall, rotor SS34). O sobrenadante foi coletado e novamente diluído em solução de sulfato de amônio saturada para que atingisse uma solução com concentração final de 90 \% de sulfato de amônio. Esta foi incubada no gelo por 30 minutos e centrifugada a $10.500 \mathrm{rpm}$ por 10 minutos a $4^{\circ} \mathrm{C}$ (Centrífuga Sorvall, rotor SS34). O sobrenadante foi 
descartado e o precipitado ressuspendido em tampão Tris-HCl 10 mM pH 7,5 contendo EDTA $1 \mathrm{mM}$. Essa solução foi dialisada três vezes a $4^{\circ} \mathrm{C}$ (3 horas cada diálise em béqueres de 4L) contra o tampão Tris- $\mathrm{HCl} 10 \mathrm{mM}$ pH 7,5 contendo EDTA $1 \mathrm{mM}$. As soluções resultantes da diálise foram estocadas a $-80^{\circ} \mathrm{C}$ e utilizadas posteriormente nos ensaios de SOD, CAT, APX e GPX. A quantidade de proteína foi determinada de acordo com o método de BRADFORD (1976), utilizando ovoalbumina como padrão.

\section{Tampão de extração:}

tampão fosfato de potássio $100 \mathrm{mM} \mathrm{pH} \mathrm{7,5} \mathrm{contendo} \mathrm{EDTA} 2 \mathrm{mM}$

\subsection{Ensaios de Superóxido Dismutase (SOD)}

Os ensaios de SOD total (CuZnSOD + MnSOD) foram realizados segundo MCCORD \& Fridovich (1969) a $25^{\circ} \mathrm{C}$ por 8 min e lidos em $550 \mathrm{~nm}$. Devido à instabilidade de seu substrato, os ensaios disponíveis de SOD são indiretos e dependem da captação de radicais superóxido e, portanto, da inibição de reações causadas por esses radicais. Um fluxo de radicais superóxido é gerado pela ação da xantina oxidase sobre a xantina. Esses radicais são medidos quanto à sua habilidade em reduzir citocromo c $\left(\mathrm{Fe}^{3+}\right)$ a citocromo $\mathrm{c}\left(\mathrm{Fe}^{2+}\right) \mathrm{e}$, portanto, SOD é quantificada quanto a sua habilidade em inibir a redução do citocromo c $\left(\mathrm{Fe}^{3+}\right)$ (BEAUCHAMP \& FRIDOVICH, 1971) (figura 12). 


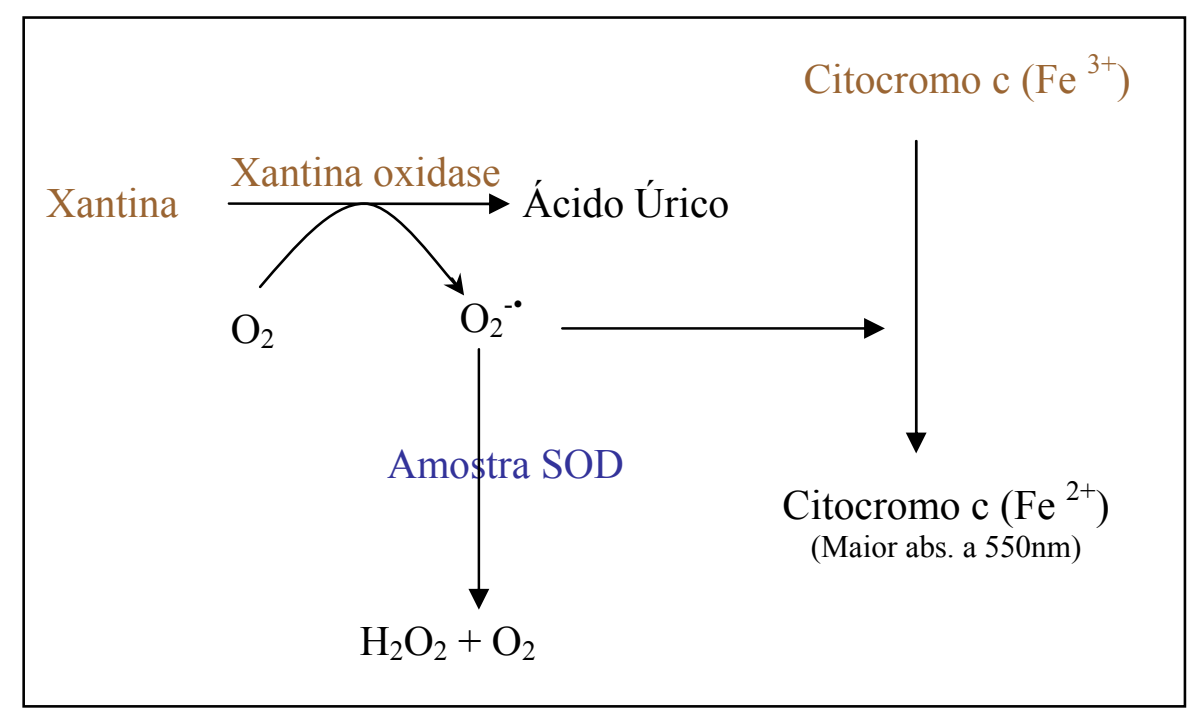

Figura 12: Apresentação esquemática do ensaio de superóxido dismutase (SOD). As palavras em marrom correspondem aos reagentes. Quanto maior a quantidade de SOD na amostra (em azul), menor a quantidade de radicais superóxido capazes de reduzir citocromo $\mathrm{c}\left(\mathrm{Fe}^{3+}\right)$ a citocromo $\mathrm{c}\left(\mathrm{Fe}^{2+}\right)$, já que $\mathrm{SOD}$ converte radicais superóxido em peróxido de hidrogênio. Desta maneira haverá maior quantidade de citocromo c $\left(\mathrm{Fe}^{3+}\right)$, que apresenta menor absorbância que o citocromo c $\left(\mathrm{Fe}^{2+}\right)$ a $550 \mathrm{~nm}$.

Para os ensaios foram preparadas, no dia, as soluções A e B. Para a cinética foram utilizados $185 \mu \mathrm{L}$ da solução $\mathrm{A}, 5 \mu \mathrm{L}$ dos diferentes extratos e $10 \mu \mathrm{L}$ da solução B, disparadora da reação, sempre com as amostras em triplicata. Para o branco, foram utilizados $185 \mu \mathrm{L}$ da solução $\mathrm{A}, 10 \mu \mathrm{L}$ da solução B e $5 \mu \mathrm{L}$ de tampão fosfato de potássio $0,05 \mathrm{M} \mathrm{pH} \mathrm{7,8.} \mathrm{Os} \mathrm{ensaios} \mathrm{foram} \mathrm{montados} \mathrm{em} \mathrm{placas} \mathrm{de} \mathrm{polipropileno} \mathrm{com}$ poços de $200 \mathrm{uL}$ e a leitura foi realizada no leitor de placas SpectraMax 190 (Molecular Device). Uma unidade de SOD foi definida como a quantidade desta enzima capaz de causar $50 \%$ de inibição da taxa de redução do citocromo c $\left(\mathrm{Fe}^{3+}\right)$ nestas condições. Foram utilizadas duplicatas de amostras biológicas diferentes.

Solução A: 9,9 mg de Ferricitocromo c $(1 \mathrm{mmol})+0,5 \mathrm{mg}$ de xantina $(5 \mu \mathrm{mol})$ em $38 \mathrm{~mL}$ de tampão fosfato de potássio $0,05 \mathrm{M} \mathrm{pH} \mathrm{7,8} \mathrm{contendo} \mathrm{0,1 \%} \mathrm{de} \mathrm{EDTA}$ $0,1 \mathrm{M}$. 
Solução B: Xantina oxidase, diluída com tampão fosfato de potássio $0,05 \mathrm{M} \mathrm{pH}$ 7,8 contendo $0,01 \%$ de EDTA $0,1 \mathrm{M}$, em concentração suficiente para produzir uma taxa de redução do ferricitocromo a $550 \mathrm{~nm}$ de 0,025 unidades de absorbância por minuto.

\subsection{Ensaios de catalase (CAT)}

Os ensaios de catalase foram realizados segundo AEBI (1984), observando-se o consumo de $\mathrm{H}_{2} \mathrm{O}_{2}$ a $20^{\circ} \mathrm{C}$ por 8 min e lidos em $240 \mathrm{~nm}$ (comprimento de onda na faixa da luz ultravioleta). A metodologia baseia-se na medida direta da atividade de catalase (figura 13).

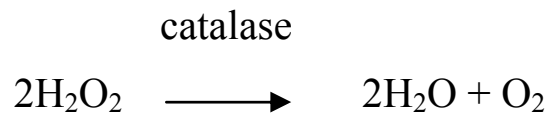

Figura 13: Reação catalisada pela catalase. Esta enzima realiza a decomposição de peróxido de hidrogênio à água e oxigênio.

A amostra (com ou sem catalase) é adicionada a uma solução de peróxido de hidrogênio $10 \mathrm{mM}$ (mantida em frasco escuro a $4^{\circ} \mathrm{C}$ ) e tampão fosfato de potássio 50 mM pH 7,8. Faz-se, então, a cinética de decaimento da concentração de peróxido de hidrogênio no sistema em comparação ao branco do experimento (sem enzima) e em comparação à curva de diferentes concentrações de $\mathrm{H}_{2} \mathrm{O}_{2}$, por meio de espectrometria a $240 \mathrm{~nm}$. Em uma placa de quartzo foram aplicados $182 \mu \mathrm{L}$ de $\mathrm{H}_{2} \mathrm{O}_{2} 10 \mathrm{mM}$ e $18 \mu \mathrm{L}$ de tampão fosfato $50 \mathrm{mM} \mathrm{pH} \mathrm{7,8} \mathrm{para} \mathrm{se} \mathrm{fazer} \mathrm{a} \mathrm{curva} \mathrm{correspondente} \mathrm{ao} \mathrm{branco,} \mathrm{e} 182 \mu \mathrm{L}$ de $\mathrm{H}_{2} \mathrm{O}_{2}, 14 \mu \mathrm{L}$ de tampão fosfato e $4 \mu \mathrm{L}$ de cada extrato para a quantificação de catalase em relação ao branco, sempre fazendo triplicata de cada amostra. Quanto à curva de peróxido foram utilizadas concentrações entre 100 nmoles e 1800 nmoles. Os ensaios foram montados em placas de quartzo com poços de $200 \mathrm{uL}$ e a leitura foi 
realizada no leitor de placas SpectraMax 190 (Molecular Device). Foram utilizadas duplicatas de amostras biológicas diferentes.

\section{$\underline{\mathrm{H}}_{2} \underline{\mathrm{O}}_{2} \underline{10 \mathrm{mM}}$ :}

$567 \mathrm{uL}$ de $\mathrm{H}_{2} \mathrm{O}_{2} 30 \%$ para volume final igual a $500 \mathrm{~mL}$ de tampão fosfato de potássio $50 \mathrm{mM} \mathrm{pH} \mathrm{7,8.}$

\subsection{Ensaios de ascorbato peroxidase (APX)}

Os ensaios de APX foram realizados segundo NAKANO \& ASADA (1981). Verificase a cinética de decaimento da concentração de ascorbato no sistema em comparação ao branco do experimento (sem enzima) e em comparação à curva de diferentes concentrações de ascorbato, em ensaios a $25^{\circ} \mathrm{C}$ por 8 min por meio de espectrometria a $290 \mathrm{~nm}$ (comprimento de onda na faixa da luz ultravioleta)(figura 14).

$$
\text { Ascorbato }+\mathrm{H}_{2} \mathrm{O}_{2} \stackrel{\text { APX }}{\longrightarrow} \text { dehidroascorbato }+2 \mathrm{H}_{2} \mathrm{O}
$$

Figura 14: Reação catalisada pela ascorbato peroxidase. Esta enzima realiza a decomposição de peróxido de hidrogênio à água utilizando ascorbato como intermediário.

Em uma placa de quartzo foram aplicados $80 \mu \mathrm{L}$ de tampão fosfato de potássio

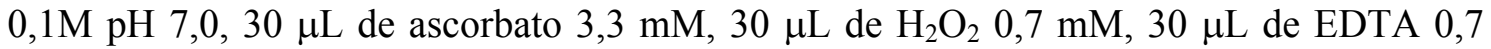
$\mathrm{mM}$ e $30 \mu \mathrm{L}$ de amostra, sempre fazendo triplicata de cada amostra. A reação é iniciada pela adição de amostra ou $\mathrm{H}_{2} \mathrm{O}_{2}$, e a diminuição na absorbância é observada de 2 em 2 minutos por 8 minutos. Para se fazer o branco substituímos a amostra por tampão fosfato de potássio $0,1 \mathrm{M} \mathrm{pH} \mathrm{7,0.} \mathrm{Quanto} \mathrm{à} \mathrm{curva} \mathrm{de} \mathrm{ascorbato} \mathrm{foram} \mathrm{utilizadas} \mathrm{concentrações} \mathrm{entre} 33$ nmoles e 264 nmoles. Uma "U" de enzima é definida como a quantidade que oxida $1 \mu$ mol de ascorbato por minuto a $25^{\circ} \mathrm{C}$. Os ensaios foram montados em placas de quartzo com poços de $200 \mathrm{uL}$ e a leitura foi realizada no leitor de placas SpectraMax 190 (Molecular Device). Foram utilizadas duplicatas de amostras biológicas diferentes. 


\section{Ascorbato 3,3mM:}

$0,0058 \mathrm{~g}$ de ascorbato para volume final igual a $10 \mathrm{~mL}$. $\mathrm{O}$ volume de todas as soluções deve ser completado com tampão fosfato de potássio $0,1 \mathrm{M} \mathrm{pH} \mathrm{7,0}$

\section{$\underline{\mathrm{H}}_{2} \underline{\mathrm{O}}_{2} \underline{0,7 \mathrm{mM}}$}

$4 \mathrm{uL}$ de $\mathrm{H}_{2} \mathrm{O}_{2} 30 \%$ para volume final igual a $500 \mathrm{uL}$. Em seguida esta solução deve ser diluída 100x.

\section{EDTA $0,7 \mathrm{mM}$ :}

$0,0026 \mathrm{~g}$ de $\mathrm{Na}_{2}$ EDTA para volume final igual a $10 \mathrm{~mL}$.

\subsection{Ensaios de glutationa peroxidase (GPX)}

O sistema de detecção indireta da atividade de GPX (E.C. 1.11.1.9) foi baseado no método de FLOHÉ \& GÜNZLER (1984) e consta de uma simulação do sistema in vivo, onde é adicionado um peróxido orgânico (t-butil-hidroperóxido), GSH (doador de elétrons para o GPX da amostra), além de NADPH e da enzima glutationa redutase (GR, para a reciclagem da GSH). A GPX dismuta o t-butil do ensaio, gerando uma ponte dissulfeto entre duas GSH (GSSG), que por sua vez volta ao estado reduzido (2GSH) pela ação da GR. A GR age mediante a oxidação de NADPH. Assim, o ensaio consiste em registrar a diminuição de $\mathrm{NADPH}$ a $37^{\circ} \mathrm{C}$ por 8 min por meio de espectrometria a $340 \mathrm{~nm}$ (figura 15).

$$
\begin{gathered}
\text { GPX } \\
2 \mathrm{GSH}+\text { t-butil (oxidado) } \rightarrow \mathrm{GSSH}+\text { t-butil (reduzido) }+\mathrm{H}_{2} \mathrm{O} \\
\mathrm{GR} \\
\mathrm{GSSG}+\mathrm{NADPH}+\mathrm{H} \rightarrow 2 \mathrm{GSH}+\mathrm{NADP}^{+}
\end{gathered}
$$

Figura 15: Reação catalisada pela glutationa peroxidase e glutationa redutase. A GPX dismuta o t-butil, gerando uma ponte dissulfeto entre duas GSH (GSSG), que por sua vez volta ao estado reduzido (2GSH) pela ação da GR. A GR age mediante a oxidação de NADPH. 
Em uma placa de quartzo foram aplicados $115 \mu \mathrm{L}$ de tampão fosfato de potássio $0,05 \mathrm{M}$ pH 7,8, $35 \mu \mathrm{L}$ de NADPH $0,9 \mathrm{mg} / \mathrm{mL}, 35 \mu \mathrm{L}$ de GSH 1,85 mg/mL, $1,5 \mu \mathrm{L}$ de GR $5 \mathrm{U} / \mathrm{mL}, 10 \mu \mathrm{L}$ de amostra e $3,5 \mu \mathrm{L}$ de t-butil 0,8\% (disparador da cinética), sempre fazendo triplicata de cada amostra. Os reagentes foram todos diluídos em tampão fosfato $50 \mathrm{mM} \mathrm{pH}$ 7,8. A diminuição na absorbância é observada de 2 em 2 minutos por 8 minutos. Quanto à curva de NADPH foram utilizadas concentrações entre 10,8 nmoles e 151,2 nmoles. Os ensaios foram montados em placas de quartzo com poços de $200 \mathrm{uL}$ e a leitura foi realizada no leitor de placas SpectraMax 190 (Molecular Device).

Apesar da diminuição linear de NADPH, resultados não podem ser expressos como consumo de substrato por tempos sem considerar a quantidade inicial de GSH, já que GPX apresenta uma cinética do tipo "ping-pong". A atividade foi calculada de acordo com a equação:

$$
\mathrm{A}=0.868\left(\Delta[\mathrm{NADPH}] /[\mathrm{GSH}]_{\mathrm{o}} \mathrm{t}\right)(\mathrm{Vi} / \mathrm{Vs}) \text {, }
$$

onde $\triangle \mathrm{NADPH} / \mathrm{t}$, é a taxa de diminuição da concentração de NADPH ao longo do tempo; $[\mathrm{GSH}]_{\mathrm{o}}$ é a concentração de GSH utilizada inicialmente; Vi e Vs são os volumes total e da amostra enzimática, respectivamente. Os resultados são apresentados em mU/(ug GSH*ug proteína). Foram utilizadas duplicatas de amostras biológicas diferentes.

\section{NADPH 0,9mg/mL:}

9mg de NADPH para volume final igual a $10 \mathrm{~mL}$. O volume de todas as soluções é completado com tampão fosfato de potássio $0,05 \mathrm{M} \mathrm{pH} 7,8$

\section{GSH $1,85 \mathrm{mg} / \mathrm{mL}:$}

0,0185g de GSH para volume final igual a $10 \mathrm{~mL}$.

\section{GR 5U/mL:}

10uL de GR a 256U/mL (160U/mg proteína x 1,6mg proteína/mL) para volume final igual a $500 \mathrm{uL}$. 
t-butil hidroperóxido $0,8 \%$ :

$12 \mathrm{uL}$ sol. $70 \%$ para volume final igual a $1,044 \mathrm{~mL}$.

\subsubsection{Antioxidantes não-enzimáticos}

\subsection{Tratamento das plantas}

Para comparar a produção de antioxidantes não-enzimáticos entre a linhagem selvagem (Ler) e mutante (tz-201), plantas de A. thaliana foram crescidas em meio sólido MS $1 / 220$ sob fotoperíodo 12 horas por 18 dias (C, controle). Plantas inteiras foram coletadas as 10a.m. e seus extratos utilizados para verificar a produção de ascorbato (ASC) e glutationa (GSH).

\subsection{Extração de ASC e GSH}

A extração de ASC e GSH foi baseada na metodologia de PotTERS et al (2000). Plantas inteiras de 18 dias das linhagens selvagem (Ler) e mutante (tz-201) foram coletadas, pesadas, e imediatamente congeladas em nitrogênio líquido até seu processamento. No dia da extração, o material foi macerado em nitrogênio líquido até produzir pó fino, mantendo-se o cadinho e o pistilo gelados durante todo o procedimento. Em seguida foi adicionado $1 \mathrm{~mL}$ de ácido meta-fosfórico (m-PA) 6\% gelado, resultando em um material pastoso. Após a maceração, as amostras foram coletadas com ponteiras previamente geladas e com suas pontas cortadas, e os materiais foram centrifugados a $14.000 \mathrm{~g}$ por $15 \mathrm{~min}$ a $4^{\circ} \mathrm{C}$. O sobrenadante foi coletado e mantido no gelo e no escuro até o uso no mesmo dia ou estocado a $-20^{\circ} \mathrm{C}$ por não mais do que uma semana. As amostras foram diluídas 1:3 na fase móvel antes da injeção. Foi feita uma curva padrão de ascorbato e glutationa com concentrações entre $25 \mathrm{uM} \mathrm{e} 100 \mathrm{mM}$.

\section{Ácido meta-fosfórico 6\%:}

$15 \mathrm{~g}$ de m-PA para volume final igual a $250 \mathrm{~mL}$ de água milliQ

\subsection{Determinação de ASC e GSH por HPLC}


A determinação de ASC e GSH foi realizada em HPLC e a separação dos compostos ocorreu em uma coluna C-18 (3 $\mu \mathrm{m}$ de diâmetro, Polaris 3 C18 column, Chromsep SS $100 \times 4,6 \mathrm{~mm})$, fase reversa, mantida em temperatura constante de $28^{\circ} \mathrm{C}$ (forno CTO-10AVP, Shimadzu). A fase móvel consistiu de $\mathrm{KCl} 2 \mathrm{mM}$, pH 2,5 por adição lenta de ácido o-fosfórico concentrado, cujo oxigênio foi removido por sonicação, e o fluxo ocorreu de maneira isocrática a $0,8 \mathrm{~mL} \mathrm{~min}^{-1}$. Foi injetado no aparelho $20 \mathrm{uL}$ à temperatura ambiente. A duração de cada corrida foi de 3 min a 252 nm para ASC e de 4 min a $194 \mathrm{~nm}$ para GSH.

\section{$\underline{\mathrm{KCl} 2 \mathrm{mM} \mathrm{pH} \mathrm{2,5}:}$}

$300 \mathrm{mg}$ de $\mathrm{KCl}$ para volume final igual a 2L. Ajustar o $\mathrm{pH}$ para 2,5 acrescentando ácido ortofosfórico concentrado, gota a gota, até atingir o pH desejado.

\subsubsection{Espécies ativas de oxigênio}

\subsubsection{Detecção de $\mathrm{H}_{2} \mathrm{O}_{2}$}

A detecção de $\mathrm{H}_{2} \mathrm{O}_{2}$ foi baseada no método de VAN GESSELEN et al (1998). As linhagens selvagem (Ler) e mutante (tz-201) foram crescidas sob hipoxia, ausência de sacarose e em condições controle, como descrito anteriormente. Plantas com 18 dias foram coletadas as 10 a.m. e o conteúdo de $\mathrm{H}_{2} \mathrm{O}_{2}$ determinado. Nesta metodologia, a produção de $\mathrm{H}_{2} \mathrm{O}_{2}$ é medida como oxidação do ácido 3,5-dichloro-2hydroxybenzenesulfonic (DCHBS) à sua forma quinona, dependente de peroxidase, que reage especificamente com 4-aminoantipyrine (AAP) para gerar um complexo molecular que absorve a $510 \mathrm{~nm}$ (VAN GESSELEN et al, 1998). Quatro a oito plantas de cada linhagem foram submersas em uma solução contendo DCHBS 10 mM, AAP $10 \mathrm{mM}$, aproximadamente $1 \mathrm{mg} / \mathrm{mL}$ de horseradish peroxidase (HRP) e meio MS $1 / 220$ líquido para completar o volume $(2 \mathrm{~mL})$. Depois de 2 horas, foram coletados $500 \mu \mathrm{L}$ de cada amostra, colocados em uma cubeta de polipropileno para ser lido em 
espectrofotômetro (Pharmacia) e, em seguida, devolvido ao ensaio. Depois das medidas o material foi pesado. Foi feita uma curva de $\mathrm{H}_{2} \mathrm{O}_{2}$ com concentrações entre $0,5 \mu \mathrm{M}$ e $40 \mu \mathrm{M}$.

\subsubsection{Perfil protéico}

\subsubsection{Extração das proteínas de A. thaliana}

Plantas das linhagens selvagem (Ler) e mutante (tz-201) foram crescidas por 18 dias em meio sólido contendo 20 g.L $\mathrm{L}^{-1}$ de sacarose, e coletadas as 10a.m (500 mg de plantas inteiras).

Para extração das proteínas de A. thaliana foi utilizado o protocolo de extração descrito por WANG et al. (2006) modificado. Plantas de A. thaliana foram maceradas em nitrogênio líquido e o pó transferido para um tubo de $2 \mathrm{~mL}$. O material foi ressuspendido em $8 \mathrm{~mL}$ de TCA 10\% (Sigma) / acetona e deixado em repouso por $2 \mathrm{~h}$ a $-20^{\circ} \mathrm{C}$. Após centrifugação a $16000 \mathrm{~g}$ por $5 \min$ a $4^{\circ} \mathrm{C}$, o sobrenadante foi removido e o precipitado foi lavado com $5 \mathrm{~mL}$ de metanol $80 \%$ / acetato de amônio 0,1M. Após misturar bem, a solução foi submetida à nova centrifugação a $16000 \mathrm{~g}$ por 3 min a $4^{\circ} \mathrm{C}$, e o sobrenadante foi, novamente, descartado. Adicionou-se, então, $5 \mathrm{~mL}$ de acetona $80 \%$ e o material foi agitado até o sobrenadante se desgrudar da parede do tubo. O material foi centrifugado, então, a 16000 g por 5 min a $4^{\circ} \mathrm{C}$ e o sobrenadante foi descartado novamente. $\mathrm{O}$ precipitado submetido à temperatura de $50^{\circ} \mathrm{C}$ por pelo menos 10 min para remover a acetona residual. Por volta de $0,1 \mathrm{~g}$ do material inicial foi ressuspendido em $0,8 \mathrm{~mL}$ fenol (tampão Tris, $\mathrm{pH}$ 8.0; Sigma) e $0,8 \mathrm{~mL}$ de tampão SDSdenso em um novo tubo de centrifuga. A mistura foi homogeneizada em vortex por 30 segundos, incubada à temperatura ambiente por $5 \mathrm{~min}$, e a fase fenólica foi separada por centrifugação a $16000 \mathrm{~g}$ por $5 \mathrm{~min} \mathrm{a} 4^{\circ} \mathrm{C}$. A fase superior fenólica foi transferida para outros tubos. Foram adicionados $5 \mathrm{~mL}$ de acetato de amônio $0,1 \mathrm{M}$ em metanol para 
precipitação das proteínas a $-20^{\circ} \mathrm{C}$ por, no mínimo, $12 \mathrm{~h}$. As proteínas precipitadas foram concentradas por centrifugação a $16000 \mathrm{~g}$ por 5 min a $4^{\circ} \mathrm{C}$, o sobrenadante foi descartado cuidadosamente, e o precipitado lavado com metanol 100\%. O material foi novamente centrifugado a $16000 \mathrm{~g}$ por $5 \mathrm{~min}$ a $4^{\circ} \mathrm{C}$, e o precipitado lavado com acetona $80 \%$. O material foi novamente centrifugado a $16000 \mathrm{~g}$ por 5 min a $4^{\circ} \mathrm{C}$ e o precipitado final foi seco a $50^{\circ} \mathrm{C}$ por 10 min.. As proteínas foram ressuspendidas em tampão de amostra para gel bidimensional e sonicadas duas vezes (30 segundos, amplitude 30, pulsos 6,5) no gelo. Entre a primeira e a segunda sonicação, as amostras foram centrifugadas a $13000 \mathrm{~g}$ por $5 \mathrm{~min} \mathrm{a} 4^{\circ} \mathrm{C}$, o sobrenadante foi coletado e submetido a $20^{\circ} \mathrm{C}$ por 2 horas. A quantidade de proteínas foi determinada de acordo com o método de BRADFORD (1976), utilizando BSA como padrão. As amostras foram armazenadas a $20^{\circ} \mathrm{C}$ negativos.

Tampão SDS-denso:

sacarose $30 \%$, SDS 2\%, Tris- $\mathrm{HCl} 0,1 \mathrm{M}, \mathrm{pH} 8.0$

Tampão de amostra para gel bidimensional:

uréia 8 M, CHAPS 4\%, IPG-buffer 2\% (Amersham Biosciences), DTT 80mM, Bromophenol blue $2 \%$

\subsubsection{SDS-PAGE e eletroforese bidimensional}

As análises de pureza e integridade da amostra e presença de degradação foram realizadas por SDS-PAGE de acordo com LAEMMLI (1970). As amostras protéicas foram desnaturadas a $95^{\circ} \mathrm{C}$ por 5 min e submetidas a SDS-PAGE em gel de acrilamida $12 \%$ (40 $\mu \mathrm{g}$ de proteína de cada amostra). Os géis de perfil protéico foram corados com Coomassie Blue R-250.

No gel bidimensional, para a primeira dimensão ou focalização isoelétrica (IEF), foram usadas fitas de gradientes de anfolitos imobilizados de $18 \mathrm{~cm} \mathrm{e} \mathrm{pH} \mathrm{4-7}$ 
(Amersham Biosciences). As fitas foram reidratadas por 14-20 h em 500 $\mu 1$ de tampão de reidratação. Em cada poço foi aplicado 800 ug de proteína. A IEF foi realizada no Multhiphor II (Amersham Biosciences) a $20^{\circ} \mathrm{C}: 1 \mathrm{~min}$ a $500 \mathrm{~V}, 30 \mathrm{~min}$ a $1500 \mathrm{~V}$ e $9 \mathrm{~h}$ a 3000 V. Para a análise da segunda dimensão, as fitas foram equilibradas individualmente por 15 min em $10 \mathrm{~mL}$ de solução de equilíbrio contendo $100 \mathrm{mM}$ de DTT. A separação da segunda dimensão foi realizada no PROTEAN II Ready Gel System (BioRad) com espaçadores de $1,5 \mathrm{~mm}$ em gel de poliacrilamida $12 \%$. As condições da eletroforese foram $15 \mathrm{~min}$ a $15 \mathrm{~mA} / \mathrm{gel}, 7 \mathrm{~h}$ a $30 \mathrm{~mA} / \mathrm{gel}$. Foram utilizadas quadruplicatas biológicas diferentes.

\section{Tampão de reidratação:}

uréia 8 M, CHAPS $2 \%$, bromophenol blue $0,002 \%$, IPG-buffer 2\%, DTT 0,2\%.

Solução de equilíbrio: uréia $6 \mathrm{M}$, glicerol 30\%, SDS 2\%, bromophenol blue $0,002 \%$, Tris $50 \mathrm{mM}, \mathrm{pH} 8,8$

\subsubsection{Visualização das proteínas, análise de imagem e quantificação}

Para a coloração com azul de Coomassie coloidal, os géis foram lavados três vezes, por 30 minutos, com solução fixadora. Em seguida, foram lavados três vezes em ácido fosfórico $2 \%$ por 20 min, e incubados em solução contendo etanol $18 \%$, sulfato de amônio $15 \%$ e ácido fosfórico $2 \%$, por 30 min. Os géis foram corados pela adição de azul de Coomassie blue G-250 coloidal $0,02 \%$ por $72 \mathrm{~h}$. Finalmente, os géis foram mantidos em solução de ácido acético $1 \%$ até a digitalização. Os géis corados foram digitalizados e calibrados com o programa Labscan (Amersham Biosciences) e as análises de imagem foram realizadas no ImageMaster $2 D$ platinum (Amersham Biosciences). A detecção dos spots e comparação entre os géis foram realizadas no programa ImageMaster $2 D$ platinum e foram conferidos e editados manualmente quando necessário. Nas análises, foram considerados como spots diferencialmente 
expressos aqueles que apresentaram variação na porcentagem de volume entre as linhagens selvagem (Ler) e mutante (tz-201) de, no mínimo, 1,4 vezes, e que ao serem submetidas à análise estatística apresentaram diferenças significativas entre as duas linhagens.

\section{Solução fixadora:}

ácido fosfórico $2 \%$ e etanol $30 \%$

\subsubsection{Identificação dos spots com expressão diferencial}

Os spots foram manualmente excisados do gel $2 \mathrm{D}$, transferidos para microtubos de 0,6 mL e digeridos com tripsina (Sigma). A digestão foi realizada em dois passos. A primeira de acordo com o protocolo de digestão em microondas (SUN et al. 2006). A segunda foi realizada com os mesmos pedaços de géis após uma nova adição de tripsina e digestão a $37^{\circ} \mathrm{C}$ durante a noite. Os fragmentos resultantes da digestão tríptica foram analisados no intervalo de 800 a 3500 Da no instrumento Maldi-TOF-TOF (Modelo 4700 Proteomics Analyser, Applied Biosystems) Version 3.0 software, tanto no modo MS quanto MS/MS. Análises da seqüência de aminoácidos foram realizadas para os cinco picos mais intensos. Alguns peptídeos identificados utilizando somente o modo MS de operação do espectrofotômetro puderam ser utilizados para identificar a proteína correspondente utilizando o algorítmo de Peptide Mass Fingerprinting (PMF), enquanto para outros, isto somente foi possível utilizando o modo MS/MS e o algoritmo MS/MS Íon Score, ambos contidos no programa MASCOT4. As identificações geradas foram confirmadas utilizando os softwares SCAFFOLD e/ou PEAKS.

\subsubsection{Quantificação de danos no DNA}

A quantificação de danos foi feita em colaboração com o Prof. Dr. Bennett Van Houten (NIEHS, NC, USA). Um estágio "sanduíche” foi realizado nesse laboratório onde foi desenvolvida a metodologia de quantificação de danos e reparo de DNA por 
PCR quantitativa. Esta técnica se baseia no fato de que determinadas lesões no DNA bloqueiam o movimento de polimerases termo-estáveis na fita molde, resultando na diminuição da amplificação desta fita. Como uma única lesão na fita de DNA é suficiente para bloquear estas polimerases, o ensaio mede efetivamente a fração de moléculas não danificadas. Conseqüentemente, danos no DNA levam a uma diminuição da amplificação da fita molde e a restauração do sinal de amplificação representa atividade de reparo de DNA (AYALA-TORRES et al., 2000) (figura 16).

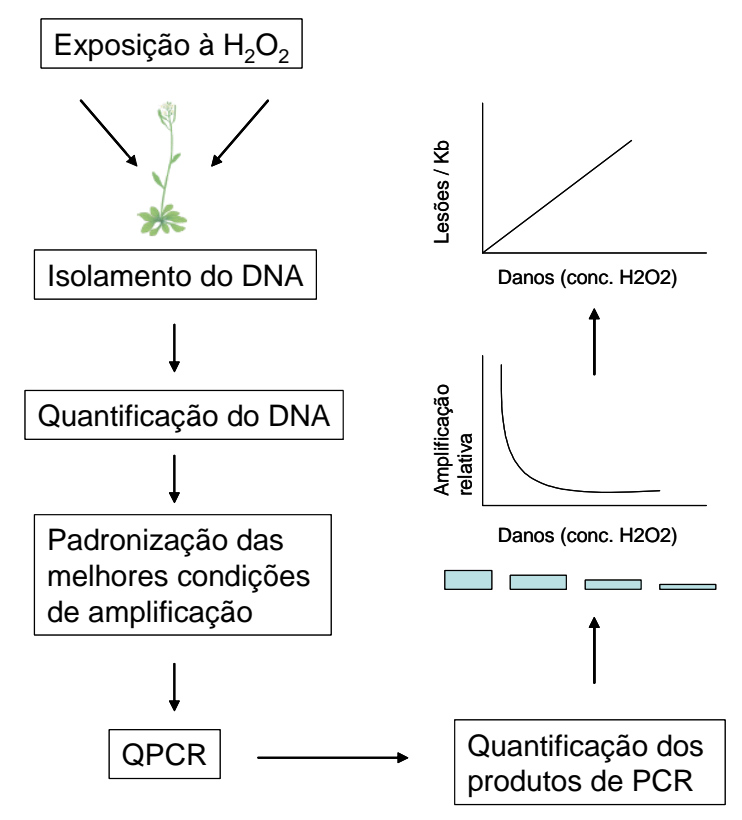

Figura 16: Visão geral dos passos necessários para realizar o ensaio de QPCR (modificado de AYALA-TORRES et al., 2000).

O processo de padronização das melhores condições para cada par de iniciador começa com a determinação da melhor temperatura. Para tanto, o primeiro experimento consiste de uma PCR em gradiente variando de $\mathrm{Tm}$ a $\mathrm{Tm}-5^{\circ} \mathrm{C}$. Após a determinação da melhor temperatura, esta se torna fixa e são feitas PCRs com diferentes números de ciclos. O melhor número de ciclos é aquele em que a amplificação se encontra na região linear da curva de PCR e cujos valores absolutos sejam os maiores. Para saber se em determinado número de ciclos os amplicons encontram-se na região linear da curva de amplificação, são feitas PCRs com 10 ng e 5 ng de amostra. A quantidade de DNA 
amplificado na amostra com $5 \mathrm{ng}$ deve ser equivalente a 0,4-0,6 da quantidade de DNA amplificado na amostra com 10 ng. Se esta relação der próxima de 1, ou não houve amplificação (é só comparar com o controle negativo), ou a amplificação já atingiu o “plateau”. Após fixar a melhor temperatura e o melhor número de ciclos, deve ser corrido um gel de agarose $0,8 \%$ (corrida a $30 \mathrm{~mA}$ por 4 horas) ou de poliacrilamida $8 \%$ (corrida a $200 \mathrm{~mA}$ por 30 minutos) para verificar se é observada uma única banda. Se não, as condições devem ser modificadas até atingir todas as condições anteriores. Uma vez que as padronizações são finalizadas para cada par de iniciador, o experimento pode ser feito com as amostras, sempre se fazendo o controle de aplicar uma amostra na metade da concentração da outra.

Para a quantificação de danos em mitocôndrias e cloroplastos, devem ser amplificados fragmento com tamanho mínimo de $8 \mathrm{~kb}$ e fragmentos com até 300pb para que os dados possam ser normalizados. Como há número diferenciado de células por tecidos e de organelas por células, devem ser amplificados fragmentos pequenos o suficiente para que nenhum dano prejudique suas amplificações e para que possamos ter idéia da quantidade de DNA organelar por amostra. Esses fragmentos pequenos devem, portanto, ser amplificados a partir da mesma amostra em que foi amplificado o fragmento grande. Todo o processo de padronização (melhor temperatura e número de ciclos) deve ser feito para esses fragmentos menores.

\subsubsection{Tratamento das plantas}

\subsubsection{1. $\mathrm{H}_{2} \mathrm{O}_{2}$}

Plantas das linhagens selvagem (Ler) e mutante (tz-201) foram cultivadas por 18 dias em meio sólido MS 1/2 20 sob fotoperíodo $12 \mathrm{~h}$. Cinco horas antes do momento de coleta, as plantas foram colocadas em meio MS 1/2 20 líquido ao qual foi adicionado 
$\mathrm{H}_{2} \mathrm{O}_{2}$ nas concentrações de $0,1 \%$ e $0,05 \%$. Como controle foram utilizadas plantas das mesmas linhagens crescidas em MS $1 / 220$ sólido por 18 dias.

\subsubsection{Extração do DNA total}

Foram coletadas $100 \mathrm{mg}$ de plantas inteiras com 18 dias as 10a.m. e seu DNA genômico foi extraído com o kit DNeasy Plant Mini (Quiagen), segundo especificações do fabricante. O rendimento dessa extração é em torno de $15 \mathrm{ng} / \mathrm{uL}$. Para verificar a qualidade das amostras, foi corrido gel de agarose pequeno, na concentração de $0,8 \%$. Foram utilizadas duplicatas (amostras biológicas diferentes) para cada experimento.

\subsubsection{Iniciadores utilizados}

Foram sintetizados iniciadores específicos para o genoma nuclear, mitocondrial e de cloroplasto (tabela 3). Para tanto, foi utilizado o programa "primer 3" (http://biotools.umassmed.edu/bioapps/primer3_www.cgi), onde foi possível delimitar características específicas para os iniciadores desenhados e para a seqüência a ser amplificada. Entre as características recomendadas para os iniciadores está uma temperatura de anelamento (Tm) alta, em torno de $68^{\circ} \mathrm{C}$, e iniciadores com, no mínimo, 20 nucleotídeos (Ayala-Torres et al, 2000). Após o desenho dos iniciadores, a seqüência a ser amplificada foi comparada com o genoma de Arabidopsis (http:/www.ncbi.nlm.nih.gov/genome/seq/BlastGen), para que cada par de iniciadores amplificasse, especificamente, genoma nuclear, ou mitocondrial, ou de cloroplasto. 
Tabela 3: Iniciadores utilizados na QPCR e suas características

\begin{tabular}{clccc}
\hline $\begin{array}{c}\text { Nome } \\
\text { iniciador }\end{array}$ & \multicolumn{1}{c}{ Sequência (5' a 3') } & $\begin{array}{c}\text { Tamanho } \\
(\mathbf{p b})\end{array}$ & $\begin{array}{c}\text { Tm } \\
\left({ }^{\circ} \mathbf{C}\right)\end{array}$ & $\begin{array}{c}\text { DNA } \\
\text { amplificado }\end{array}$ \\
\hline ClrepFpq & CCG CCA CAC GAG AGG GAC AT & 720 & 62 & cloroplasto \\
ClrepRpq & GGA ACG CGG ACA CAG GTG GT & & 62,6 & \\
MitrepFpq & CCA ATC ACC ACA GCG CGA GA & 748 & 60,3 & mitocôndria \\
MitrepRpq & GCC GGA GGA AAT GGG ATT CG & & 58,5 & \\
Chloleftprimer & TAA TTG GCG CGC TTG AGG AA & \multirow{2}{*}{115} & 70,1 & cloroplasto \\
LtCHLOrv & CGG AAA AGC CAA GGG GTC AA & & 70,1 & \\
Mitleftprimer & GGT CTC GTC GCT TCG GTG AA & \multirow{2}{*}{131} & 69,3 & mitocôndria \\
LtMITrv & TCG AGC GAT GAC AAC CAG GA & & 69,3 & \\
ClrepFgr & CGG GCG GAT TCC TCC TTT TG & 8238 & 58,7 & cloroplasto \\
ClrepRgr & TTC ATT TGG GAC CCC GCA GA & & 59,3 & \\
MitrepFgr & GCC CCG GTC AGT GGA GTC AA & 8769 & 62,1 & mitocôndria \\
MitrepRgr & CGT TCC CGG AGG TGG CTC TT & & 62 & \\
Ara5 & GTT TGA GCT GTC TAC TAA & 8263 & 38 & núcleo \\
R11 & CTT GTT AGG TCT TCC TCT & & \\
\hline
\end{tabular}

\subsubsection{Condições utilizadas nas PCRs}

Reação de amplificação de DNA com os iniciadores ClrepFpq e ClrepRpq (cloroplasto, 720pb), e MitrepFpq e MitrepRpq (mitocôndria, 748pb), utilizando a Taq DNA polymerase (Biolabs):

\begin{tabular}{|c|c|c|c|}
\hline Reação para 1 amostra & Volumes (uL) & \multicolumn{2}{|c|}{$\begin{array}{l}\text { Programa máquina de PCR } \\
\end{array}$} \\
\hline 10xPCR buffer minus Mg & 5 & Cloroplasto (720pb) & Mitocôndria (748pb) \\
\hline $10 \mathrm{mM}$ dNTP mix & 1 & $\begin{array}{l}\text { ClrepFpq } \\
\text { ClrepRpq } \\
\end{array}$ & $\begin{array}{l}\text { MitrepFpq } \\
\text { MitrepRpq }\end{array}$ \\
\hline $50 \mathrm{mM} \mathrm{MgCl}{ }_{2}$ & 1,5 & $94^{\circ} \mathrm{C} 3 \mathrm{~min}$. & $94^{\circ} \mathrm{C} 3 \mathrm{~min}$. \\
\hline 10uM primer forward & 1 & $94^{\circ} \mathrm{C} 45 \mathrm{~s}$ & $94^{\circ} \mathrm{C} 45 \mathrm{~s}$ \\
\hline 10uM primer reverse & 1 & $57,3^{\circ} \mathrm{C} 30 \mathrm{~s}$ & $54,4^{\circ} \mathrm{C} 30 \mathrm{~s}$ \\
\hline Molde DNA (15ng/uL) & 10 & $72^{\circ} \mathrm{C} 1 \mathrm{~min}$. e $30 \mathrm{~s}$. & $72^{\circ} \mathrm{C} 1$ min. e $30 \mathrm{~s}$. \\
\hline Taq DNA polimerase (5U/uL) & 0,5 & voltar $34 \mathrm{x}$ ao passo 2 & voltar $34 \mathrm{x}$ ao passo 2 \\
\hline Água & 30 & $72^{\circ} \mathrm{C} 10 \mathrm{~min}$ & $72^{\circ} \mathrm{C} 10 \mathrm{~min}$ \\
\hline
\end{tabular}

Reação de amplificação de DNA com os demais iniciadores mostrados na tabela

3. Para essas reações foi utilizada a enzima rTth DNA polymerase XL (Applied Biosystems) nas seguintes condições:

\begin{tabular}{|c|c|}
\hline Reação para 1 amostra & Volumes $(\mathrm{uL})$ \\
\hline Água & 9,6 \\
\hline Tampão $3,3 \mathrm{x}$ & 15 \\
\hline BSA $(1 \mathrm{mg} / \mathrm{mL})$ & 5 \\
\hline dNTP $(2,5 \mathrm{mM}$ cada $)$ & 4 \\
\hline
\end{tabular}




\begin{tabular}{|c|c|}
\hline $\mathrm{MgO}(\mathrm{Ac}) 2(25 \mathrm{mM})$ & 2,4 \\
\hline forward primer $(10 \mathrm{uM})$ & 2 \\
\hline reverse primer $(10 \mathrm{uM})$ & 2 \\
\hline rTth XL & 5 \\
\hline (diluição $1: 10$ em tampão $1 \mathrm{x})$ & 5 \\
\hline molde de DNA $(2 \mathrm{ng} / \mathrm{uL})$ & \\
\hline
\end{tabular}

\begin{tabular}{|c|c|c|c|c|}
\hline \multicolumn{5}{|c|}{ Programas máquina de PCR } \\
\hline $\begin{array}{l}\text { Núcleo } \\
\text { (8263pb) }\end{array}$ & $\begin{array}{l}\text { Mitocôndria } \\
(8769 \mathrm{pb})\end{array}$ & $\begin{array}{c}\text { Cloroplasto } \\
\text { (8238pb) }\end{array}$ & $\begin{array}{c}\text { Cloroplasto } \\
\text { (115pb) }\end{array}$ & $\begin{array}{l}\text { Mitocôndria } \\
(131 \mathrm{pb})\end{array}$ \\
\hline $\begin{array}{l}\text { Ara5 } \\
\text { R11 }\end{array}$ & $\begin{array}{l}\text { MitrepFgd } \\
\text { MitrepRgd }\end{array}$ & $\begin{array}{l}\text { ClrepFgd } \\
\text { ClrepRgd }\end{array}$ & $\begin{array}{l}\text { Chloleftprimer } \\
\text { LtCHLOrv }\end{array}$ & $\begin{array}{l}\text { Mitleftprimer } \\
\text { LtMITrv }\end{array}$ \\
\hline $75^{\circ} \mathrm{C} 2 \mathrm{~min}$. & $75^{\circ} \mathrm{C} 2$ min. & $75^{\circ} \mathrm{C} 2$ min. & $75^{\circ} \mathrm{C} 2 \mathrm{~min}$. & $75^{\circ} \mathrm{C} 2$ min. \\
\hline $94^{\circ} \mathrm{C} 1 \mathrm{~min}$. & $94^{\circ} \mathrm{C} 1 \mathrm{~min}$. & $94^{\circ} \mathrm{C} 1 \mathrm{~min}$. & $94^{\circ} \mathrm{C} 1 \mathrm{~min}$. & $94^{\circ} \mathrm{C} 1 \mathrm{~min}$. \\
\hline $94^{\circ} \mathrm{C} 30 \mathrm{~s}$ & $94^{\circ} \mathrm{C} 15 \mathrm{~s}$ & $94^{\circ} \mathrm{C} 15 \mathrm{~s}$ & $65^{\circ} \mathrm{C} 45 \mathrm{~s}$ & $65^{\circ} \mathrm{C} 45 \mathrm{~s}$ \\
\hline $39,7^{\circ} \mathrm{C} 30 \mathrm{~s}$. & $57^{\circ} \mathrm{C}-63,8^{\circ} \mathrm{C} 45 \mathrm{~s}$ & $54,9^{\circ} \mathrm{C} 45 \mathrm{~s}$. & $72^{\circ} \mathrm{C} 45 \mathrm{~s}$ & $72^{\circ} \mathrm{C} 45 \mathrm{~s}$ \\
\hline $72^{\circ} \mathrm{C} 9 \mathrm{~min}$. & $72^{\circ} \mathrm{C} 10 \mathrm{~min}$. & $72^{\circ} \mathrm{C} 10 \mathrm{~min}$. & $\begin{array}{c}\text { voltar } 26 \mathrm{x} \text { ao } \\
\text { passo } 2\end{array}$ & $\begin{array}{c}\text { voltar } 26 \mathrm{x} \text { ao } \\
\text { passo } 2\end{array}$ \\
\hline $\begin{array}{c}\text { voltar } 26 \mathrm{x} \text { ao } \\
\text { passo } 3\end{array}$ & $\begin{array}{c}\text { voltar } 21 \mathrm{x} \text { ao } \\
\text { passo } 3\end{array}$ & $\begin{array}{c}\text { voltar } 28 \mathrm{x} \text { ao } \\
\text { passo } 3\end{array}$ & $72^{\circ} \mathrm{C} 5$ min. & $72^{\circ} \mathrm{C} 5 \mathrm{~min}$. \\
\hline $72^{\circ} \mathrm{C} 5 \mathrm{~min}$. & $72^{\circ} \mathrm{C} 10 \mathrm{~min}$. & $72^{\circ} \mathrm{C} 10 \mathrm{~min}$. & & \\
\hline
\end{tabular}

O DNA foi diluído com água ou TE 1x, inicialmente a $10 \mathrm{ng} / \mathrm{uL}$, sendo quantificado em fluorímetro com picogreen (Invitrogen), e posteriormente diluído a 2 $\mathrm{ng} / \mathrm{uL}$.

\subsubsection{Tiamina}

Os experimentos de padronização de quantificação de tiamina livre, monofosfato e pirofosfato foram realizados em colaboração com o Prof. Paolo di Mascio (Instituto de Química, Departamento de Bioquímica) juntamente com sua aluna de doutorado Graziella Eliza Ronsein (Processo FAPESP n ${ }^{\circ}$ 04/01664-0).

\subsubsection{Extração de tiamina}

A extração das diferentes formas de tiamina em A. thaliana foi baseada na metodologia de MANCINELLI et al (2003).

Um grama de plantas inteiras com 18 dias das linhagens selvagem (Ler) e mutante (tz-201) foi crescido em meio sem tiamina, coletado as 10 a.m. e triturado em nitrogênio líquido com PVPP e pó de vidro. Esse macerado foi ressuspendido em $3 \mathrm{~mL}$ 
de TCA $10 \%$ (Sigma) $\left(4^{\circ} \mathrm{C}\right)$, vortexado e mantido por 1 hora no escuro à temperatura ambiente para precipitar as proteínas. Posteriormente, o material foi centrifugado a 2.000 g por 20 min a $4^{\circ} \mathrm{C}$ e o sobrenadante foi coletado. $\mathrm{O}$ material foi submetido à sonicação a $700 \mathrm{~W}$ Duty Cycle $30 \%$ por $2 \min$ a $4^{\circ} \mathrm{C}$ e, posteriormente, foi centrifugado a $2.000 \mathrm{~g}$ por $10 \mathrm{~min}$ a $4^{\circ} \mathrm{C}$. Em seguida o TCA foi removido por 5 volumes de éter dietílico saturado com água (misturar a amostra com éter e descartar a fase superior) e, subseqüentemente, foi filtrado através de um filtro para seringa de $0,45 \mu \mathrm{m}$ (Corning). Para garantir a oxidação de tiamina a tiocromo, $500 \mu \mathrm{L}$ de sobrenadante foi diluído com $400 \mu \mathrm{L}$ de água, e a esta solução foi adicionado $50 \mu \mathrm{L}$ de $\mathrm{K}_{4} \mathrm{Fe}(\mathrm{CN})_{6} \quad 30,4 \mathrm{mM}$ (preparado no dia), sendo esta amostra agitada por 30 segundos. Posteriormente, foi adicionado $50 \mu \mathrm{L}$ de $\mathrm{NaOH} 0,8 \mathrm{mM}$, e esta solução foi novamente agitada por 30 segundos. Diferentes volumes de injeção de amostras com diferentes ganhos de sensibilidade do aparelho foram testados, mas a melhor combinação obtida foi a de aplicação de $50 \mu \mathrm{L}$ concomitantemente ao ganho de $16 \mathrm{x}$.

Foram preparadas soluções estoque dos padrões de tiamina na concentração de $1 \mathrm{mM}$ em $\mathrm{HCl} 0,1 \mathrm{M}$, que foram posteriormente diluídas em água para atingir a concentração desejada. Foi feita uma solução com $0,5 \mathrm{~mL}$ de tiamina livre $1 \mathrm{mM}, 0,5$ $\mathrm{mL}$ de tiamina monofosfato $1 \mathrm{mM}, 0,5 \mathrm{~mL}$ de tiamina pirofosfato $1 \mathrm{mM}, 50 \mu \mathrm{L}$ de $\mathrm{K}_{4} \mathrm{Fe}(\mathrm{CN})_{6} 30,4 \mathrm{mM}, 50 \mu \mathrm{L}$ de $\mathrm{NaOH} 0,8 \mathrm{mM}$ e $0,4 \mathrm{~mL}$ de água milliQ. Foi injetada em HPLC $50 \mu \mathrm{L}$ desta solução.

\subsubsection{Condições cromatográficas}

As condições cromatográficas se baseiam na metodologia descrita por MANCINELLI et al (2003). Utilizamos um HPLC LC10AD Shimadzu acoplado a um detector de fluorescência $\mathrm{RF}-551$ e uma coluna supelcosil LC- $\mathrm{NH}_{2}$ (Supelco), $250 \mathrm{x}$ 4,6 mm, $5 \mu \mathrm{M}$, acoplada a uma pré coluna LC- $\mathrm{NH}_{2}$ (Supelco). Como fase móvel, 
utilizamos tampão fosfato de potássio $85 \mathrm{mM} \mathrm{pH} \mathrm{7,5} \mathrm{-} \mathrm{acetonitrila}(65: 35$, v/v) e um fluxo de $1 \mathrm{~mL} / \mathrm{min}$. A detecção por fluorescência foi realizada a $375 \mathrm{~nm}$ de excitação e $430 \mathrm{~nm}$ de emissão. Como padrão foi utilizada uma solução de tiamina livre, monofosfato e pirofosfato contendo 100 pmol de cada. Como controle foi aplicado em HPLC os componentes da reação $\left(\mathrm{K}_{4} \mathrm{Fe}(\mathrm{CN})_{6}\right.$ e $\left.\mathrm{NaOH}\right)$ sem os padrões ou as amostras.

\subsubsection{Análises estatísticas}

Os dados de massa fresca, de antioxidantes não-enzimáticos, de carboidratos de baixo peso molecular e de proteômica, foram comparados utilizando-se a análise de variância unifatorial (ANOVA one-way), enquanto os dados de expressão de mRNA thi1 em plantas submetidas à hipoxia e crescidas em meio sem sacarose, de enzimas antioxidantes e de quantificação de $\mathrm{H}_{2} \mathrm{O}_{2}$, foram comparados utilizando-se a análise de variância bi-fatorial (ANOVA two-way). Quando as comparações entre as médias apresentaram diferenças, foi feito o tesse de Tukey, tesse de comparação entre médias, sendo considerado significante um $\alpha \leq 0.05$, usando-se o programa Statistica 6.0.

Métodos de análise multivariada foram realizados para comparar cromatogramas mostrando carboidratos de baixo peso molecular, utilizando-se as linhagens selvagem (Ler) e mutante (tz-201). Para evitar possíveis distorções de um método de análise específico, foram usados 2 tipos de análises multivariadas: PCA (principal component analysis) e CVA (canonical variate analysis). PCA e CVA foram realizados com o sistema S-Plus, e também com o programa de informática Pirouette 2.6 (Infometrix, Woodinville, WA). Em seguida, para comparar compostos iguais entre linhagens diferentes foi realizado o tesse de análise de variância unifatorial (ANOVA one-way) e, posteriormente, foi feito o tesse de Dunett, tesse de comparação entre médias, sendo considerado significante um $\alpha \leq 0.05$, usando o programa JMP 5.0.1. Enquanto o tesse de 
Dunett compara todas as amostras com um controle previamente escolhido, o tesse de Tukey compara todas as amostras entre si. 


\section{Resultados}

\subsection{Modulação da expressão do gene thi1 em A. thaliana}

\subsubsection{Análise transcricional}

KASHIWABARA (2003) obteve linhagens independentes de plantas contendo construções gênicas que aumentam da expressão do gene thi1 (senso, thi $1_{s} a$ ) e que diminuem sua expressão (antisenso, thi $1_{a s} a$ ). KASHIWABARA (2003) observou, por Northern blot, aumento na expressão de thi1 na linhagem senso de aproximadamente 2,5x, e redução na expressão do mesmo gene na linhagem antisenso de aproximadamente $2 \mathrm{x}$, estas porcentagens em relação às linhagens selvagem (Ler) e mutante (tz-201) que não apresentaram expressão alterada entre si. Re-analisamos esses dados por RT-qPCR, pois além desta ser uma técnica mais sensível, as transgênicas utilizadas nesse trabalho são da geração $T_{3}$ enquanto KASHIWABARA (2003) trabalhou com transgênicas da geração $\mathrm{T}_{2}$. A análise dos níveis de thi1 mRNA nas plantas transgênicas $\mathrm{T}_{3}$ por RT-qPCR corroborou o aumento da expressão do gene thi1 na senso e a diminuição da expressão na antisenso, como observado por KASHIWABARA (2003), porém no presente trabalho foi observado um aumento na expressão das transgênicas senso por RT-qPCR muito maior do que aquele observado por Northern blot. Os experimentos mostram um silenciamento de $2 x$ para a linhagem antisenso (figura 17) e um aumento de 10x nas plantas transgênicas senso (figura 17) em comparação com a expressão de thi1 nas linhagens selvagem (Ler) e mutante (tz-201). 


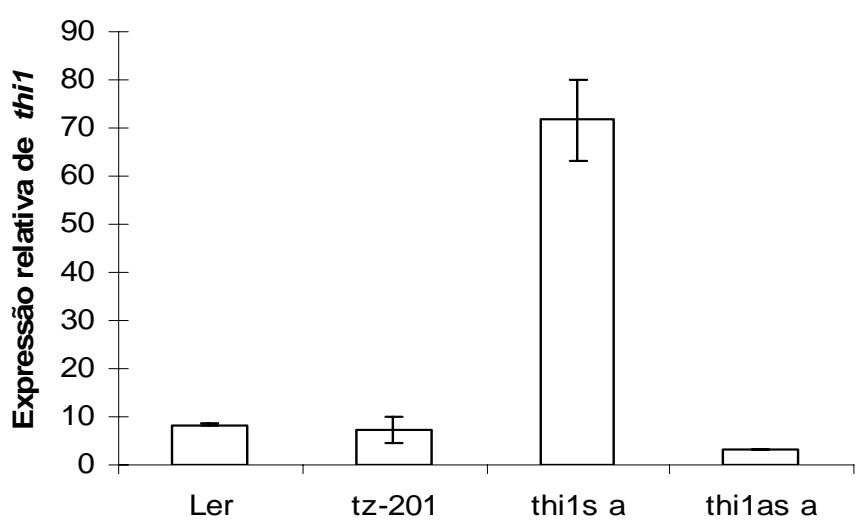

Figura 17: Expressão relativa de mRNA thi1 utilizando-se linhagens de A. thaliana selvagem (Ler), mutante (tz-201), thi $1_{s} a$ e thi $1_{a s} a$ crescidas por 18 dias. As plantas foram coletadas as 10a.m., para se comparar a expressão de thi1 entre as linhagens. Os dados representam a média de dois experimentos independentes e são mostrados como valores relativos, já que esses referem-se à expressão de thi1 nas diferentes amostras em relação à expressão do gene constitutivo ubiquitina.

RIBEIRO et al (2005) transformou plantas do ecótipo Ler de A. thaliana com um fragmento do promotor thi1 compreendendo a região da posição -16 à posição -608 (Pthi608) em relação ao sitio de início de tradução, fusionado ao gene repórter $\beta$ glucuronidase (GUS). Na figura $18 \mathrm{~B}$ (C-, controle negativo), não foi observada expressão de GUS, o que nos indica que não há expressão endógena (ou se há, é muito baixa) do gene GUS. Na figura $18 \mathrm{~B}(\mathrm{C}+$, controle positivo), foi observada a expressão desse gene. Em plantas Pthi608, crescidas em meio com sacarose (dados não mostrados), não foi observada expressão em nenhum tecido, mesmo em diferentes horários de coleta.

Entretanto, foram observadas diferenças na expressão do gene GUS em plantas Pthi608 crescidas em meio sem sacarose e coletadas em diferentes horários. Como se pode observar na figura $18 \mathrm{~B}$, as 9 am e as 9 pm não foi observada a expressão do gene GUS em nenhum tecido. As 12 am, foi observada expressão nas folhas e raiz, com maior expressão nas raízes. As 3 pm, foi observada expressão nas raízes e nas folhas, 
com maior expressão nas folhas. As 6 pm, foi observada expressão nas folhas e raízes, entretanto de maneira mais homogênea.

Real Time

A)

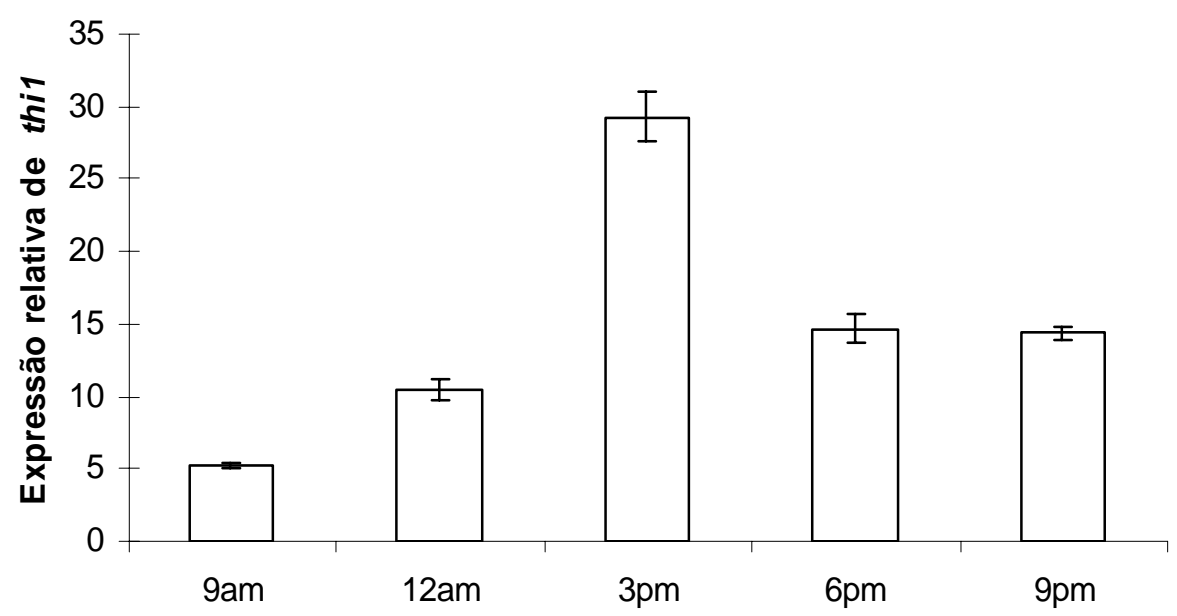

B)
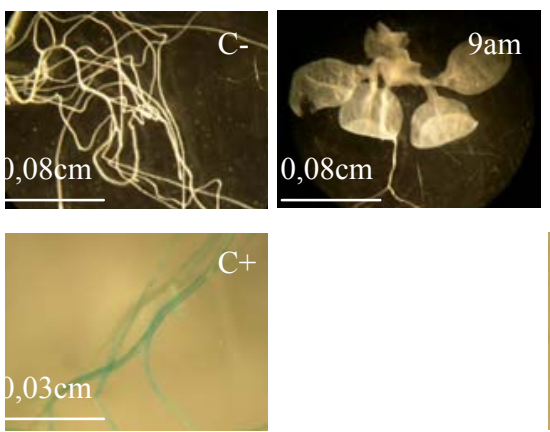
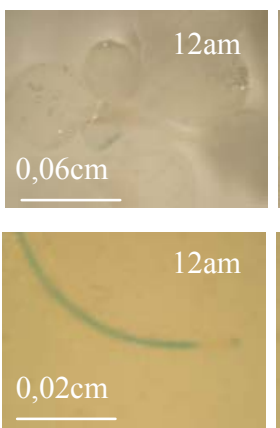
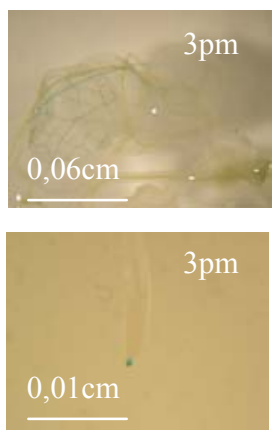
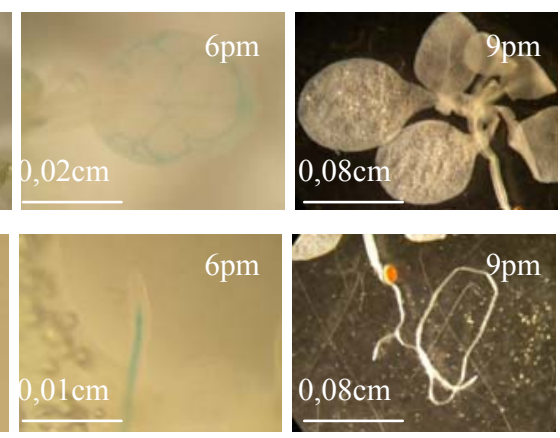

Figura 18: Expressão de RNAthi1 por RT-qPCR (A) e análise histoquímica (B) de plantas de $A$. thaliana crescidas por 18 dias e coletadas em diferentes horários (9am, $12 \mathrm{am}, 3 \mathrm{pm}, 6 \mathrm{pm}$ e $9 \mathrm{pm}$ ). Para os experimento de RT-qPCR, foram utilizadas plantas da linhagem selvagem (Ler), e os dados representam a média de dois experimentos independentes e são mostrados como valores relativos, já que esses referem-se à expressão de thi1 nas diferentes amostras em relação à expressão do gene constitutivo ubiquitina14. Para os experimentos de análise histoquímica foram utilizadas plantas selvagens (Ler) e transgênicas (P35S+GUS e Pthi608) para se analisar a influência da presença e/ou ausência de sacarose na expressão de thi1 ao longo do dia. C-: controle negativo (Ler); $\mathrm{C}+$ : controle positivo (P35S+GUS); as demais fotos representam plantas crescidas em meio sem sacarose coletadas nos horários indicados em cada figura.

Foi analisada, também, a influência da luz na expressão de thi1. Utilizando apenas a linhagem selvagem, foi observada (figura 18A) uma tendência à maior expressão de RNAm thi1 as 3p.m.. Como dois experimentos independentes, com 
triplicatas, apresentaram a mesma tendência (pico de expressão as $3 \mathrm{pm}$.), o experimento anterior foi ampliado com coletas de 3 em 3 horas por 3 dias, com plantas submetidas a fotoperíodo $16 \mathrm{~h}$ e plantas submetidas a claro contínuo (em câmaras climáticas), a fim de verificar se estas variações seriam devido à regulação circadiana de thi1 ou simplesmente relacionadas à variações de luz na condição dia/noite.

Pode-se observar na figura 19 (condição CE) um pico 18h, 42h e 66h após início do tratamento (exposição à claro total ou permanência do fotoperíodo $16 \mathrm{~h}$ ). O intervalo entre esses picos é de 24 h. Há flutuações na expressão gênica, com níveis menores à noite e níveis maiores durante o dia, sendo os níveis do transcrito thi1 maiores à tarde. Na figura 19 (condição CC), em que as plantas foram submetidas à claro contínuo (curso livre), pode-se observar um padrão bastante parecido com aquele da condição CE. Pode-se observar um pico $15 \mathrm{~h}, 45 \mathrm{~h}$ e $66 \mathrm{~h}$ após início do tratamento que, entretanto, estão ligeiramente fora de fase em relação aos picos observados na condição CE.

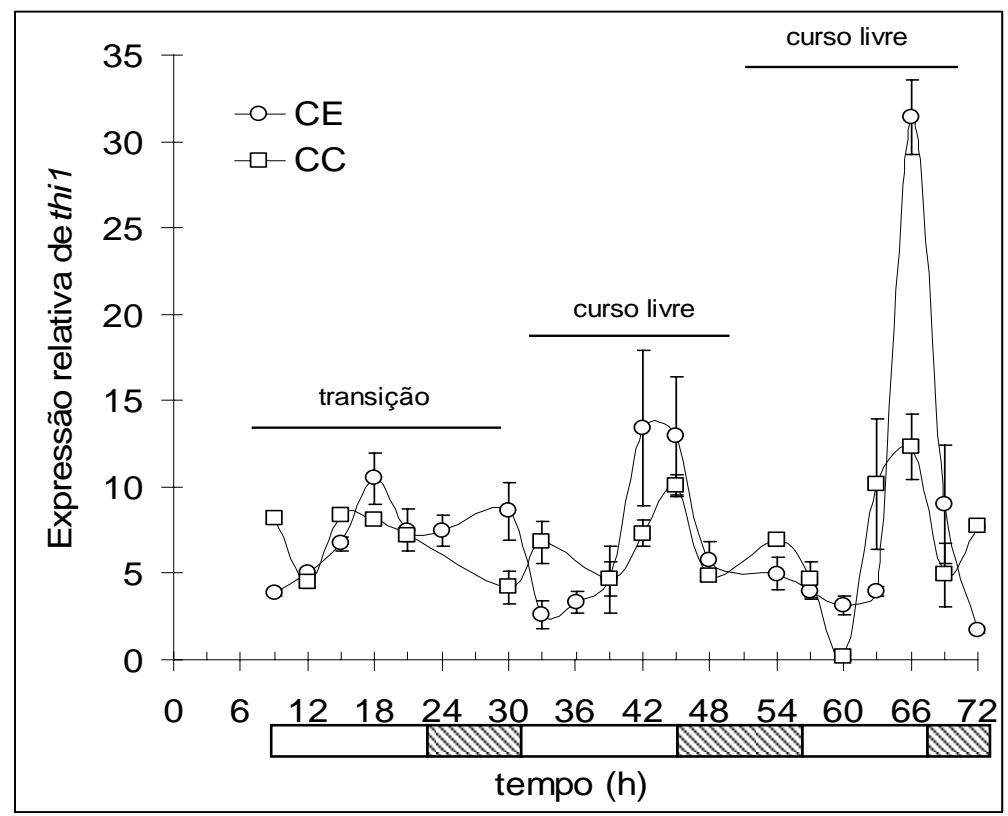

Figura 19: Ritmo circadiano. Expressão relativa de mRNA thi1 utilizando-se plantas selvagem (Ler) de A. thaliana. CE: Plantas submetidas à fotoperíodo $16 \mathrm{~h}$ por $72 \mathrm{~h}$. CC: Plantas submetidas à condição de claro contínuo (curso livre). Os retângulos hachurados sob o eixo $\mathrm{x}$ indicam o período de noite para a condição CE e período de noite subjetiva para a condição CC.,Os retângulos brancos indicam o período de dia para a condição $\mathrm{CE}$ e de dia subjetivo para a condição $\mathrm{CC}$. Noites e dias subjetivos indicam a posição de 
dias e noites caso as condições permanecessem em alternância de períodos de luz e escuro. Os dados representam a média de dois experimentos independentes e são mostrados como valores relativos, já que esses referem-se à expressão de thi1 nas diferentes amostras em relação à expressão do gene constitutivo ubiquitina.

\subsubsection{Análise traducional}

Para complementar os dados de expressão de RNAm thi1 nas linhagens selvagem (Ler), mutante (tz-201), senso (thi1 ${ }_{s} a$ ) e antisenso (thi ${ }_{a s} a$ ) (figura 17), foi analisada a produção da proteína THI1 nestas 4 linhagens, utilizando os extratos destas linhagens, da proteína THI1 purificada (controle positivo) e da proteína At-XPB 1 purificada (controle negativo), para se ter idéia da quantidade de proteína THI1 presente nos diferentes extratos.

Por meio de slot blot e usando anticorpo primário anti-THI1, foi detectada a proteína THI1 tanto no controle positivo quanto nos extratos, enquanto a proteína AtXPB 1 recombinante não foi detectada, como era esperado. Comparando a intensidade das bandas em relação ao controle positivo pode-se deduzir que aproximadamente $0,9 \%, 0,5 \%, 0,6 \%$ e $1 \%$ das proteínas presentes nos extratos das plantas selvagem, mutante, senso e antisenso, respectivamente, são proteína THI1 (figura 20).

Para complementar os dados de expressão de RNAm thi1 referentes à influência de thi1 pela luz (figura 18A), em que foi observado um pico de expressão as $3 \mathrm{pm}$., foi analisada a produção da proteína THI1 em plantas selvagens coletadas em diferentes períodos do dia (3pm, 4pm, 5pm e 6pm) (figura 21). Pode-se observar um pico de produção de THI1 as 5pm. 


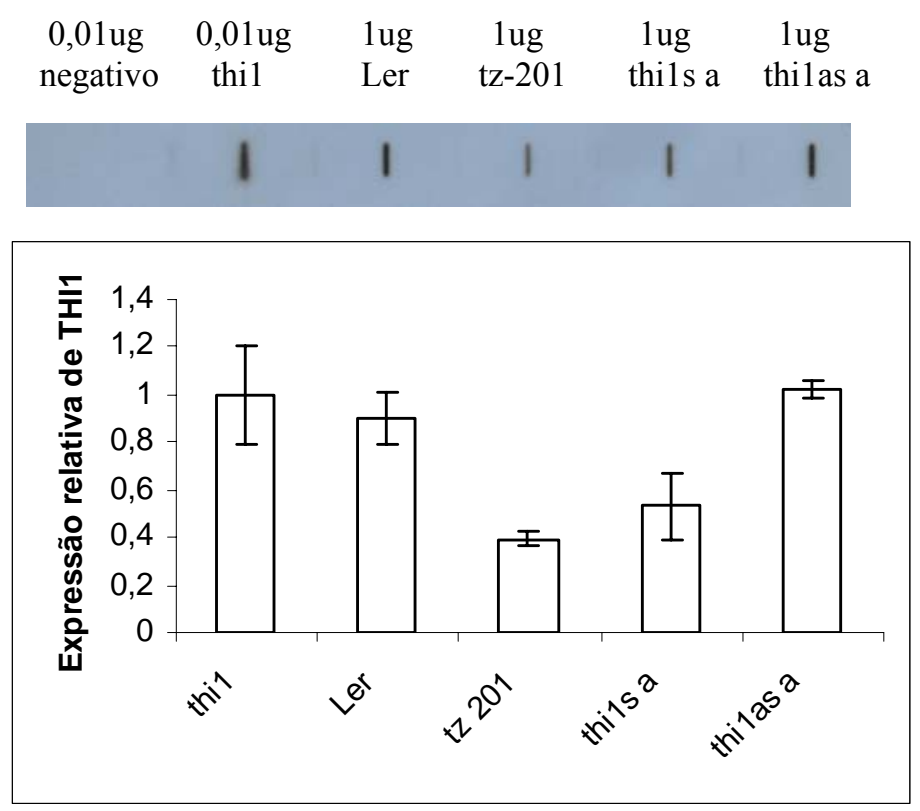

Figura 20: Slot blot. Análise quantitativa da proteína THI1 em extratos das linhagens selvagem (Ler), mutante (tz-201), senso (thi1s a) e antisenso (thias a) e em controles positivo (thi1, proteína THI1 recombinante) e negativo (-, At-XPB 1 recombinante). Foram aplicados $1 \mu \mathrm{g}$ de cada extrato e $0,01 \mu \mathrm{g}$ das amostras purificadas. Os valores foram calculados por densitometria usando "1D Image Analysis Software (Kodak Digital Science)". Barras de erro representam o desvio padrão entre duplicatas. O controle positivo foi considerado $1 \mathrm{e}$ os demais foram calculados em relação à amostra thi1.

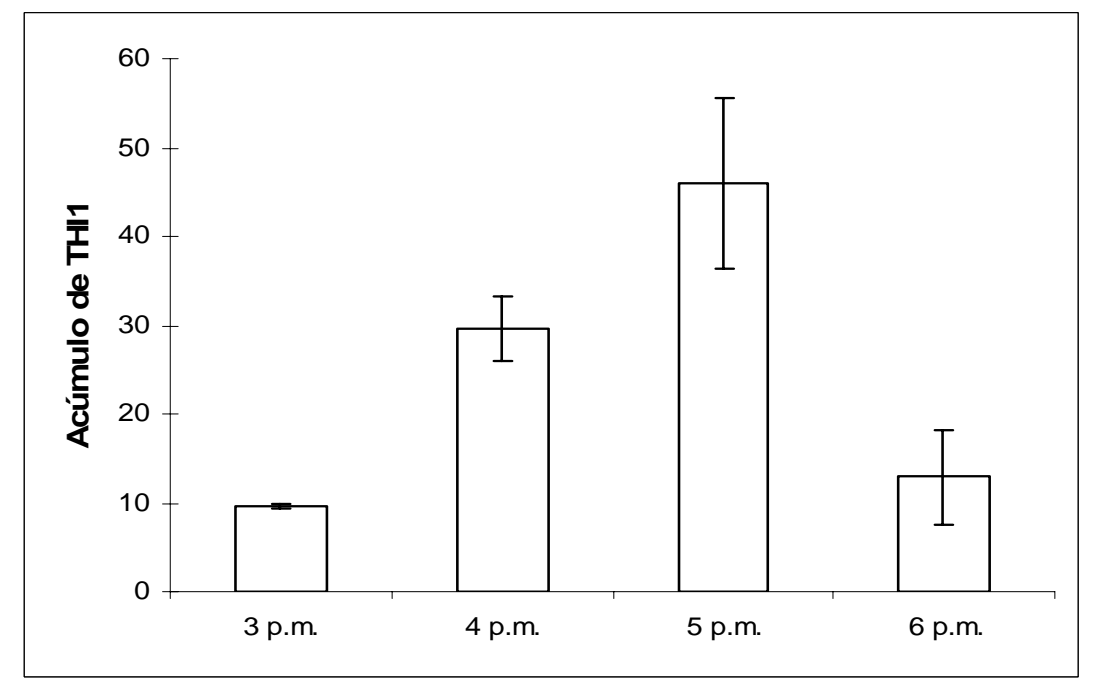

Figura 21: A análise quantitativa da proteína THI1 foi feita com extratos da linhagem selvagem (Ler) de A. thaliana crescida por 18 dias. As plantas foram coletadas em diferentes horários $(3 \mathrm{pm}, 4 \mathrm{pm}, 5 \mathrm{pm}, 6 \mathrm{pm})$ para se analisar a influência do fotoperíodo na produção de THI1. Os valores foram calculados por densitometria usando "1D Image Analysis Software" (Kodak Digital Science). Barras de erro representam o desvio padrão entre duplicatas. 


\subsection{Aspectos bioquímicos e fisiológicos associados ao gene thi1}

\subsubsection{Taxa de germinação de sementes}

O experimento de taxa de germinação de sementes foi realizado com sementes das linhagens selvagens (Ler), mutantes (tz-201) e transgênicas (thi1s a e thi1as a) de A. thaliana estocadas por 3, 6 e 9 meses, ou sem serem estocadas (0). Sementes das linhagens selvagem, mutante, senso e antisenso, germinadas imediatamente após coleta (0), apresentaram taxas de germinação de $98 \%, 98 \%, 97 \%$ e $96 \%$, respectivamente. Aquelas estocadas por 3 meses, apresentaram taxa de germinação de 97\%, 96\%, 95\% e $95 \%$, respectivamente. As sementes estocadas por 6 meses apresentaram taxa de germinação de $81 \%, 65 \%, 92 \%$ e $91 \%$, e aquelas estocadas por 9 meses apresentaram taxas de germinação de $48 \%, 21 \%, 76 \%$ e $79 \%$, respectivamente (figura 22 ).

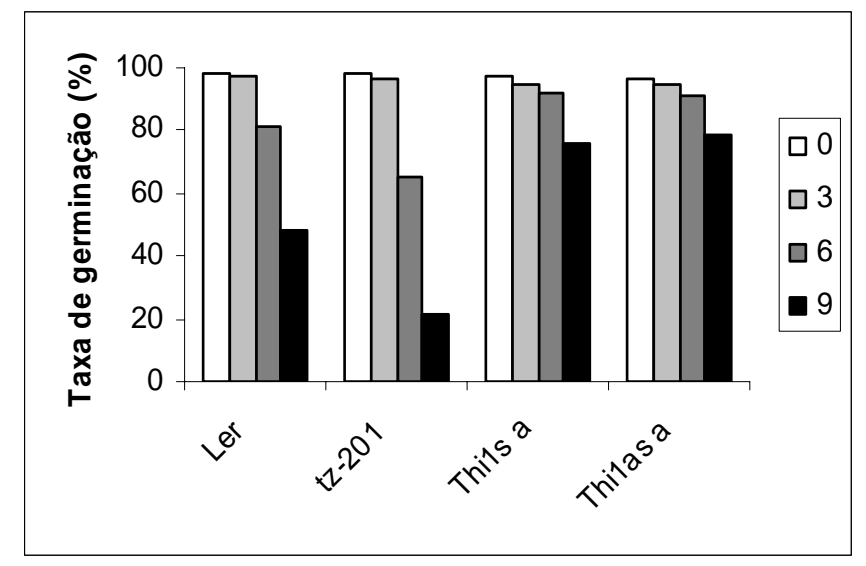

Figura 22: Taxa de germinação. Porcentagem de sementes germinadas das linhagens selvagem (Ler), mutante (tz-201), thi $1_{s} a$ (senso) e thi $1_{a s} a$ (antisenso) de Arabidopsis thaliana estocadas por 3, 6 e 9 meses, ou não estocadas $(0)$.

Até 3 meses de estocagem, as porcentagens de germinabilidade das sementes entre as diferentes linhagens foram semelhantes e apresentaram altos valores. A partir de 6 meses, as sementes de todas as linhagens apresentam queda na viabilidade, e foi possível observar diferenças de germinabilidade entre as linhagens. As sementes das linhagens transgênicas apresentaram maior viabilidade, enquanto as do ecótipo 
selvagem apresentaram viabilidade intermediária $\mathrm{e}$ as da linhagem mutante apresentaram menor viabilidade. As diferenças entre as linhagens foram ainda maiores após estocagem por 9 meses (figura 22)

\subsubsection{Massa fresca}

Para a caracterização inicial das linhagens selvagem (Ler) e mutante (tz-201), foi feito experimento de quantificação da massa fresca de plantas inteiras, folhas e raízes, ao longo do desenvolvimento das plantas (figura 23).

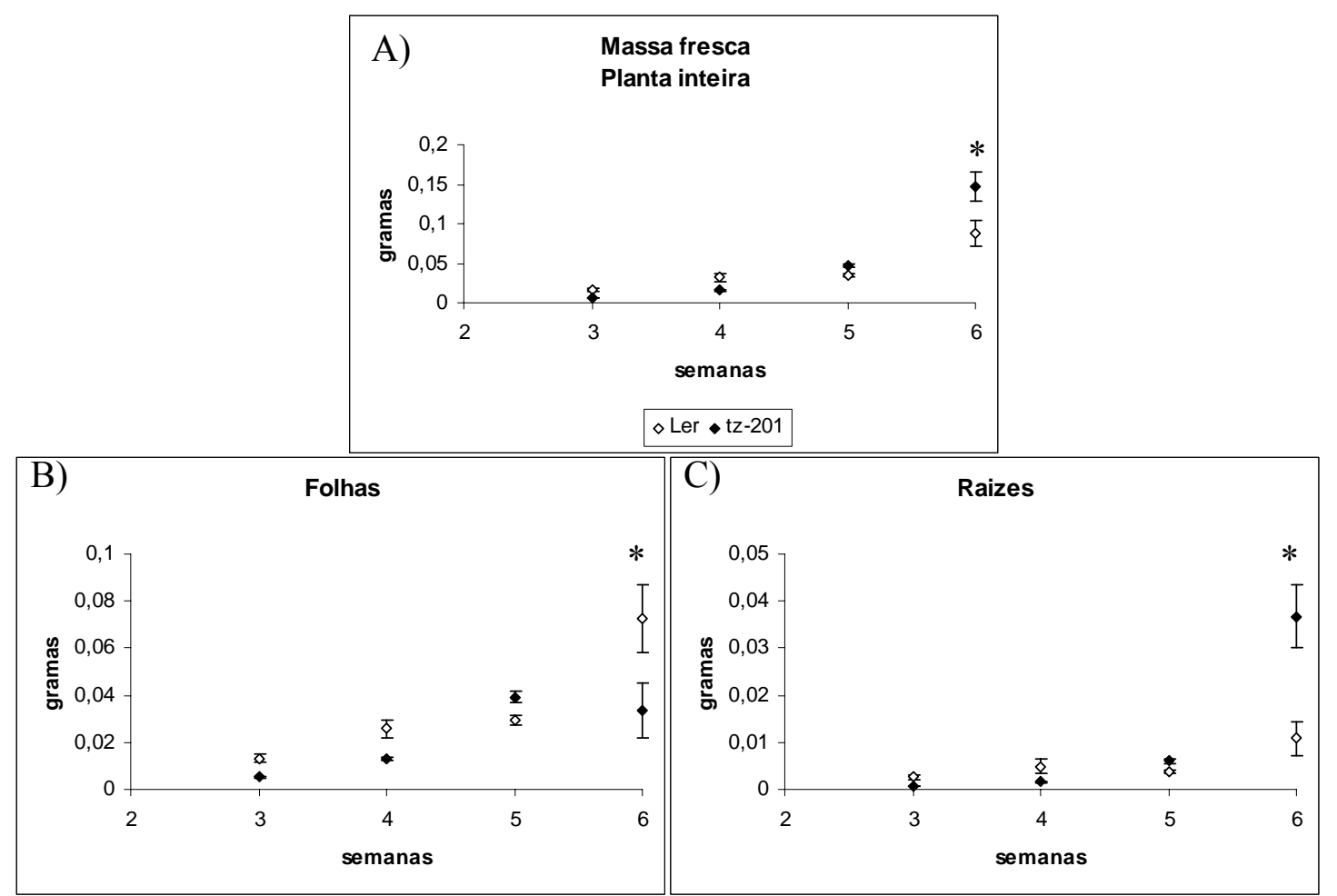

Figura 23: Massa Fresca. Determinação de massa fresca de planta inteira (A), parte aérea (B) e raiz (C) das linhagens selvagem (Ler) e mutante (tz-201) de A. thaliana. Quinze plântulas de cada linhagem com 3, 4, 5 e 6 semanas foram coletadas e pesadas em balança analítica. $\mathrm{O}$ asterisco indica diferenças estatisticamente significativas entre as linhagens.

Considerando a planta inteira (figura 23A) e somente as raízes (figura 23C), a linhagem mutante possui, após 6 semanas, massa fresca maior que a do ecótipo selvagem. Em contrapartida, considerando somente as folhas (figura 23B), o ecótipo selvagem possui massa fresca maior que a da mutante. 


\subsubsection{Carboidratos de baixo peso molecular}

Como o gene thi1 está envolvido em síntese de tiamina, cofator presente em várias vias metabólicas, foram quantificados carboidratos de baixo peso molecular nas linhagens selvagem (Ler) e mutante (tz-201) para verificar se haveria diferenças entre as duas linhagens. Nas análises por PCA e CVA (comparação estatística dos cromatogramas), somente os primeiros dois eixos foram usados já que somente esses eixos tinham padrão suficientemente não-randômico para serem interpretados (dados não mostrados). PCA mostrou que amostras independentes da linhagem selvagem permaneceram agrupadas, o que não aconteceu com linhagem mutante. Por CVA, amostras independentes das mesmas linhagens (tanto da selvagem quanto da mutante) permaneceram mais agrupadas.
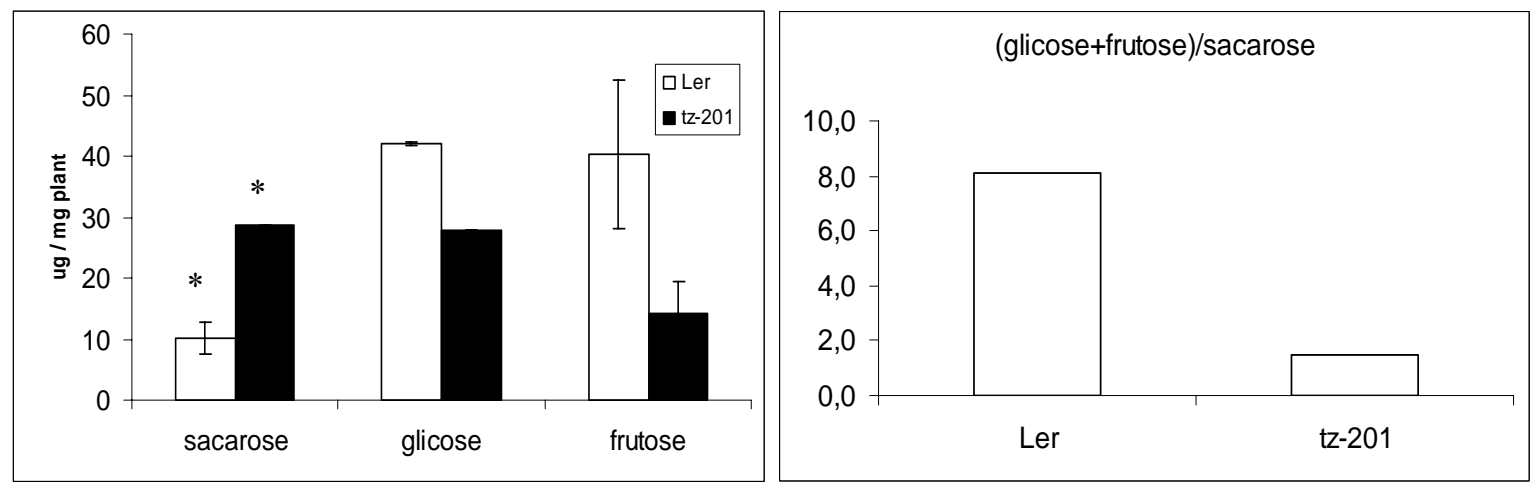

Figura 24: Análise de carboidratos de baixo peso molecular por CG-MS em extratos de plantas das linhagens selvagem (Ler) e mutante (tz-201) de A. thaliana. Barras de erro representam o desvio padrão entre triplicatas. Os asteriscos indicam quais linhagens são diferentes entre si. Foi feito análise de variância unifatorial (one-way anova) que indica quais compostos diferem entre as linhagens, sendo considerado significante quando $\mathrm{P} \leq 0.05$.

As principais diferenças observadas na análise desses perfis metabólicos foram quanto à sacarose, frutose e glicose. A linhagem mutante apresentou aumento na quantidade de sacarose em relação à linhagem selvagem, e diminuição na quantidade de glicose e frutose em relação à linhagem selvagem (figura 24A). A taxa (glicose+frutose)/sacarose foi $5,5 \mathrm{x}$ maior na selvagem em relação à mutante (figura 
24B). Esse dado nos informa que a linhagem mutante tem mais sacarose do que hexoses livres comparando-a com a selvagem.

\subsubsection{Antioxidantes}

Para verificar se a expressão do RNAm thi1 das linhagens selvagem (Ler) e mutante (tz-201) de A. thaliana é alterada em plantas crescidas em meio sem sacarose ou sob condição de hipoxia (C:controle; SL: sólido/líquido; SLS: sólido/líquido/sólido), plantas crescidas nestas condições tiveram seu RNAm extraído, transformado em cDNA e esse foi submetido a RT-qPCR. Na figura 25A, pode-se observar que não houve diferença significativa na expressão do RNAm thi1 entre as linhagens selvagem e mutante na condição sem sacarose e na condição controle. Já na figura 25B, pode-se observar maior expressão de RNAm thi1 na linhagem mutante em relação à selvagem na condição SL (sólido/líquido). Apesar da diferença observada na condição SLS não ser significativa estatisticamente, vemos também nesta condição uma tendência à maior expressão de RNAm thi1 na mutante em relação à selvagem.

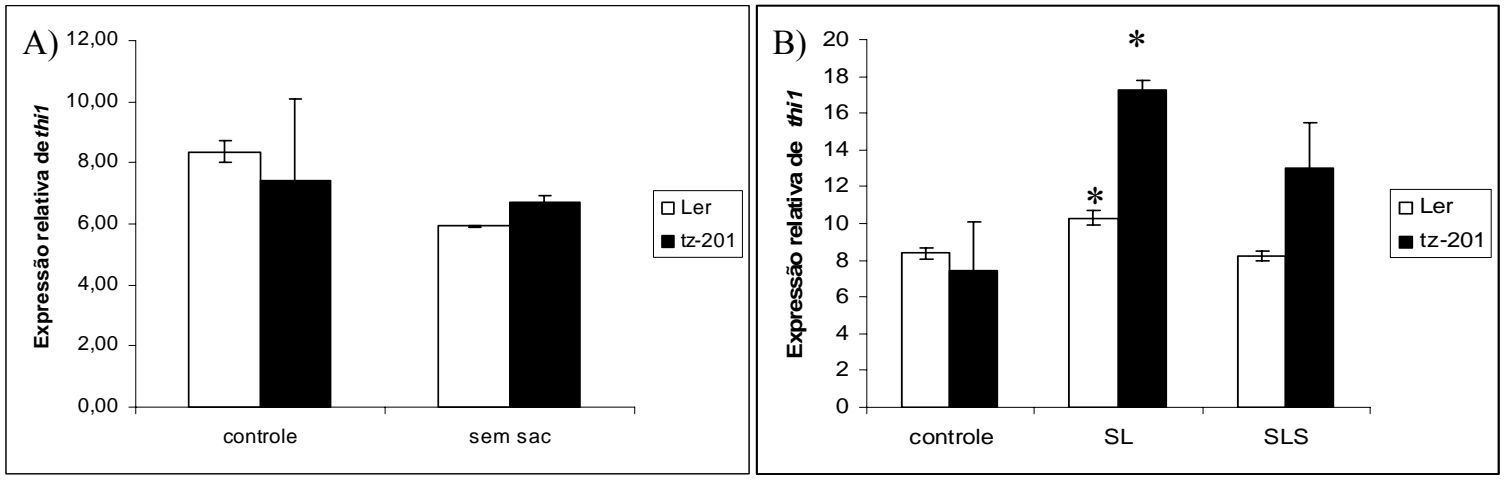

Figura 25: Expressão relativa do RNAm thi1 utilizando-se linhagens de $A$. thaliana selvagem (Ler) e mutante (tz-201) crescidas por 18 dias. Plantas crescidas em meio sem sacarose (A) e plantas crescidas sob hipoxia (B) foram coletadas as 10a.m., para se comparar a expressão de thi1 entre as linhagens. Controle: plantas crescidas em meio sólido contendo 20 g. $\mathrm{L}^{-1}$ de sacarose por 18 dias; SL: plantas crescidas em meio sólido por 14 dias e então transferidas para meio líquido por 4 dias; SLS: plantas crescidas em meio sólido por 14 dias, transferidas para meio líquido por 2 dias e então transferidas para meio sólido por 2 dias; Sem sacarose: plantas crescidas em meio sem sacarose por 18 dias. Os dados representam a média de dois experimentos independentes e são mostrados como valores relativos, já que esses referem-se à 
expressão de thi1 nas diferentes amostras subtraindo-se a expressão do gene constitutivo ubiquitina. Os asteriscos representam grupos diferentes estatisticamente.

Como RiBEIRo et al (2005) observou que o promotor de thi1 é modulado por luz e é responsivo à ausência de açúcar e hipoxia, foram utilizadas como condições experimentais alterações de fotoperíodo, crescimento das plantas na ausência de sacarose e hipoxia na análise da atividade de enzimas antioxidantes (SOD, CAT, APX e GPX). Plantas das linhagens selvagem (Ler) e mutante (tz-201) de A. thaliana foram submetidas a fotoperíodo $12 \mathrm{~h}$ / escuro total por diferentes períodos (figura 26).

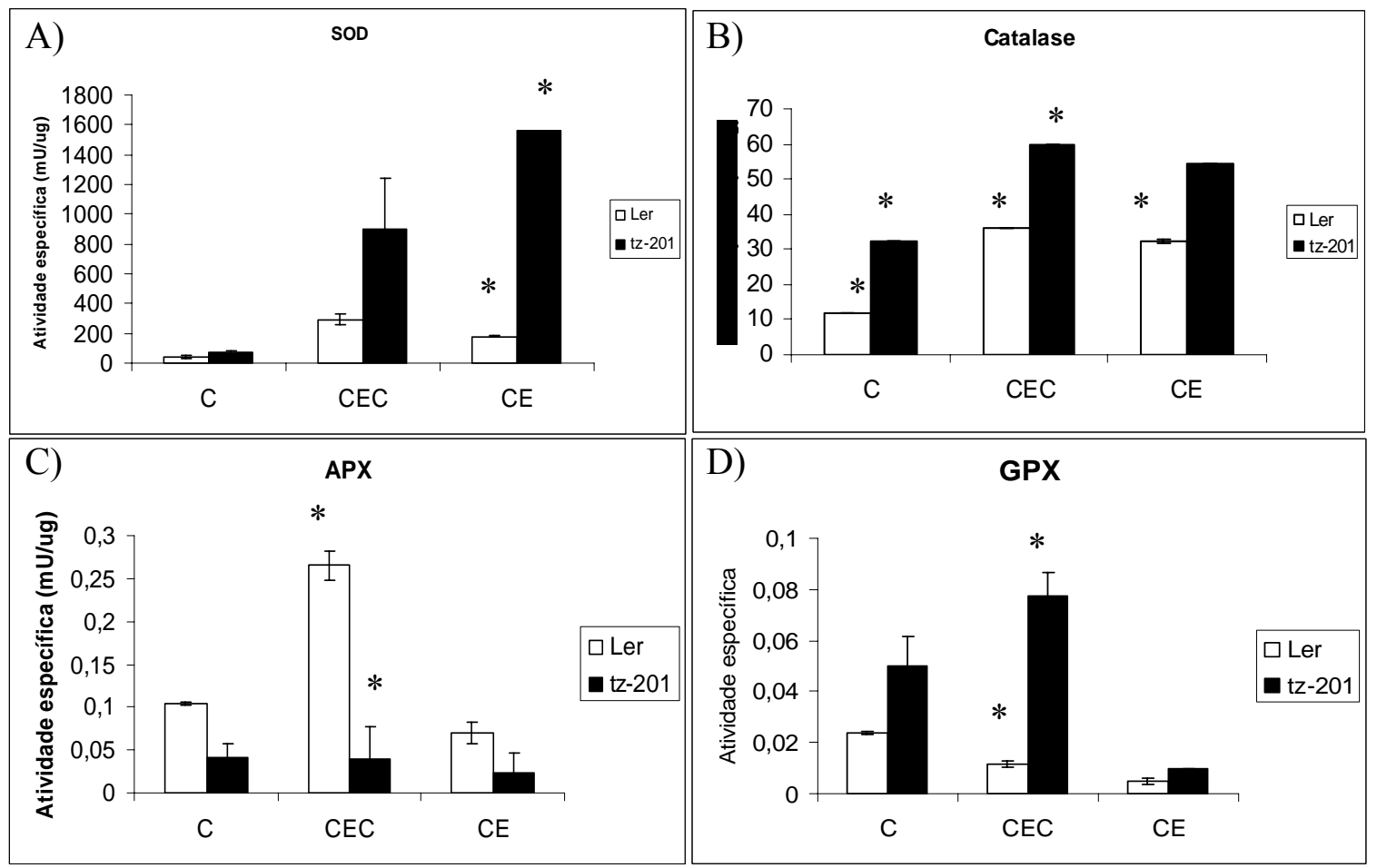

Figura 26: Atividades específicas de superóxido dismutase (SOD) (A), catalase (CAT) (B), ascorbato peroxidase (APX) e glutationa peroxidase (GPX) em linhagens selvagem (Ler) e mutante (tz-201) de A. thaliana expostas a diferentes condições luminosas. C: plantas crescidas sob fotoperíodo $12 \mathrm{~h}$ por 18 dias; CEC: plantas crescidas sob fotoperíodo $12 \mathrm{~h}$ por 14 dias, transferidas para escuro total por 2 dias e então transferidas para fotoperíodo 12 horas por mais 2 dias; CE: plantas crescidas sob fotoperíodo $12 \mathrm{~h}$ por 14 dias e então transferidas para escuro total por 4 dias. Os dados representam a média de valores de dois experimentos independentes e são mostrados como valores absolutos. Os valores são considerados significantemente diferentes quando $\mathrm{P} \leq 0.05$.

Pode-se observar no ensaio de SOD (figura 26A), maior atividade desta enzima na linhagem mutante, na condição CE. Apesar da diferença observada na atividade de 
SOD entre as 2 linhagens na condição CEC não ser significativa estatisticamente, podese observar uma tendência da linhagem mutante apresentar maior atividade de SOD que a selvagem também nesta condição. Já no ensaio de CAT (figura 26B), foi observado que a linhagem mutante sempre apresentou maior atividade que a selvagem, mesmo na condição controle. Foi observado maior atividade de GPX (figura 26D) na linhagem mutante submetida à condição CEC, enquanto a APX (figura 26C) apresentou maior atividade na linhagem selvagem, em plantas submetidas à condição CEC.

Foi analisada a produção de ROS, quantificando $\mathrm{H}_{2} \mathrm{O}_{2}$, nas condições controle e em crescimento sob hipoxia (figura 27A). Houve um aumento na produção de $\mathrm{H}_{2} \mathrm{O}_{2}$, principalmente na linhagem selvagem, nas condições SL e SLS. Entretanto, a linhagem mutante sempre apresentou menor quantidade de $\mathrm{H}_{2} \mathrm{O}_{2}$ do que a linhagem selvagem.

Da mesma forma, foi verificada a atividade de enzimas antioxidantes nas condições controle e sob hipoxia. Nenhuma diferença foi observada na atividade de SOD (figura 27B) e de APX (figura 27D) entre as linhagens selvagem e mutante submetidas a diferentes condições. Entretanto, foi observada maior atividade de CAT na linhagem mutante em relação à selvagem, nas condições controle, SLS e SL, com valores de atividade de CAT muito maior para a condição SLS (figura 27C). Foi observada, também, maior atividade de GPX (figura 27E) na linhagem mutante submetida às condições SL e SLS. 

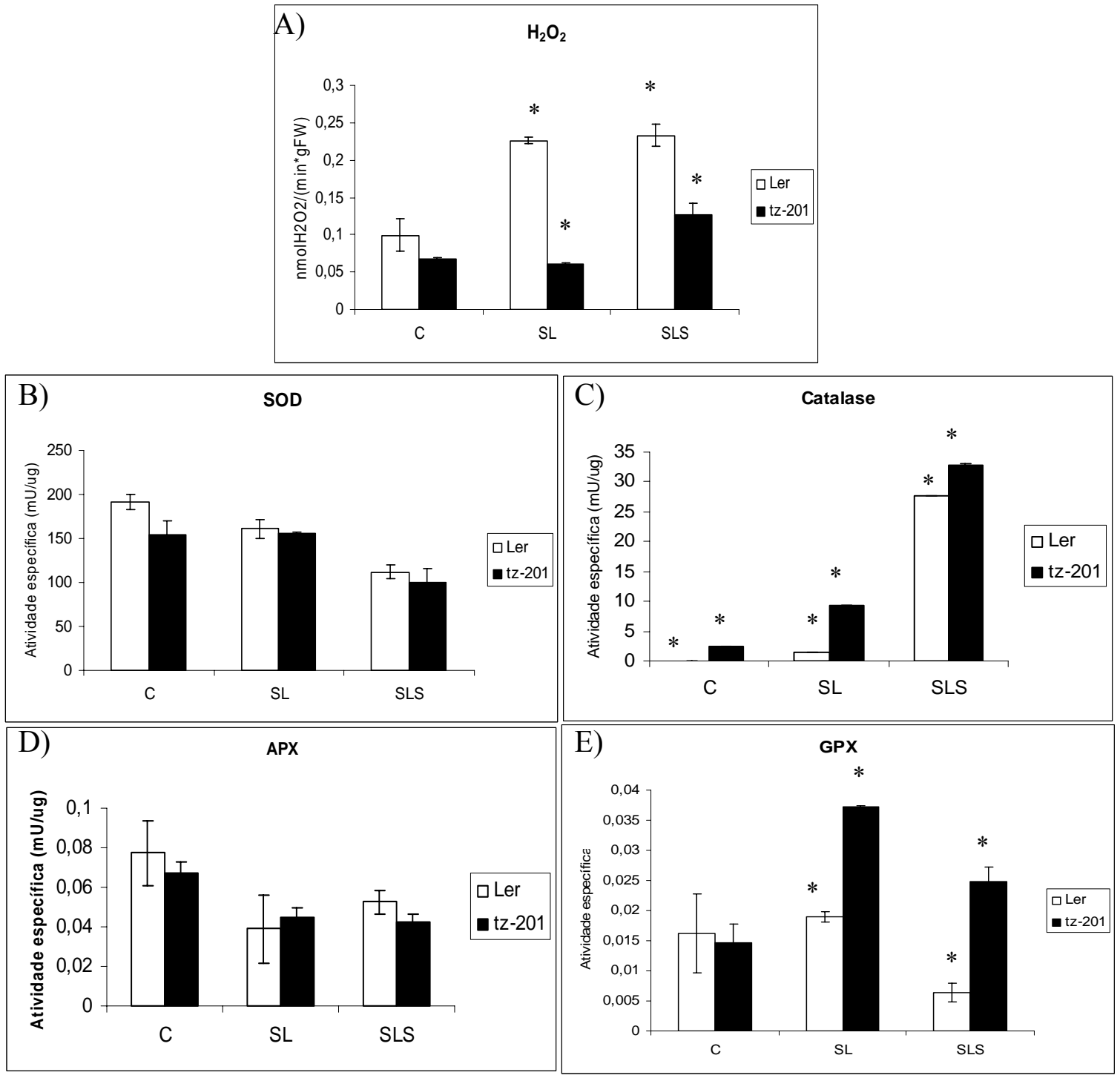

Figura 27: $\mathrm{H}_{2} \mathrm{O}_{2}$ (A) foi quantificado usando A. thaliana selvagem (Ler) e mutante (tz201) in vivo. Para medir atividades específicas de SOD (B), CAT (C), APX (D) e GPX (E) foram usados extratos destas mesmas linhagens, crescidas sob hipoxia (SL e SLS). C: Plantas foram crescidas em meio sólido contendo 20 g.L $\mathrm{L}^{-1}$ de sacarose por 18 dias; SL: Plantas foram crescidas em meio sólido por 14 dias e então transferidas para meio líquido por 4 dias; SLS: Plantas foram crescidas em meio sólido por 14 dias, transferidas para meio líquido por 2 dias e então transferidas para meio sólido por 2 dias. Os dados representam a média de valores de dois experimentos independentes e são mostrados como valores absolutos. Os valores são considerados significantemente diferentes quando $\mathrm{P} \leq 0.05$.

Foi analisada, também, a produção de ROS, quantificando $\mathrm{H}_{2} \mathrm{O}_{2}$ em plantas crescidas em meio sem sacarose. Não houve aumento na produção de $\mathrm{H}_{2} \mathrm{O}_{2}$ comparando as 2 linhagens entre si, mas houve aumento na produção de $\mathrm{H}_{2} \mathrm{O}_{2}$ na condição "sem sacarose" em relação à condição controle como um todo (figura 28A). 
Da mesma forma, foi verificada a atividade de enzimas antioxidantes em plantas crescidas na ausência de sacarose. Foi observada maior atividade de SOD (figura 28B) e GPX (figura 28E) na linhagem mutante crescida em meio sem sacarose, mas não foi observada maior atividade de CAT (figura 28C) e de APX (figura 28D) nesta condição.

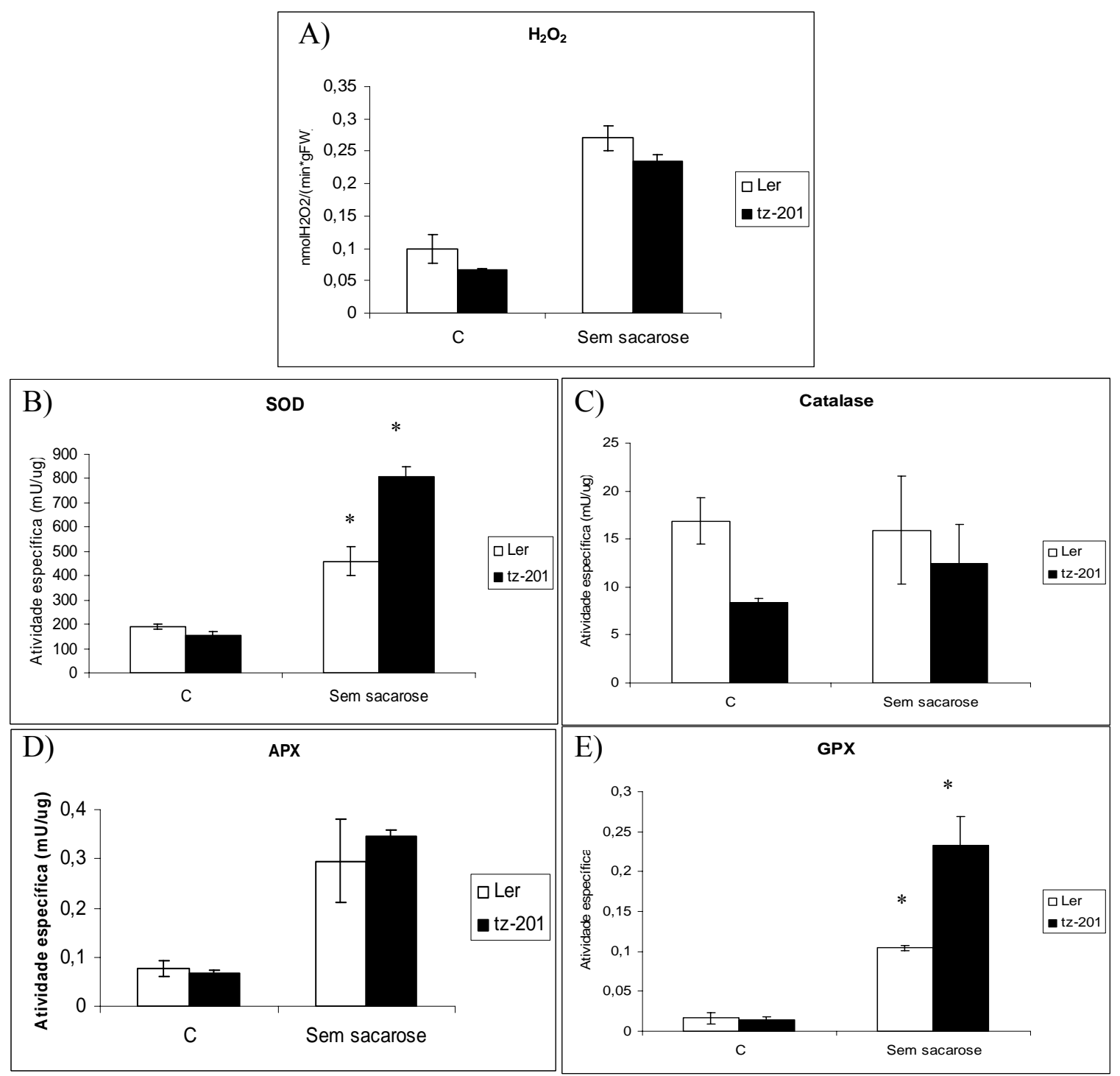

Figura 28: $\mathrm{H}_{2} \mathrm{O}_{2}$ (A) foi quantificado usando A. thaliana selvagem (Ler) e mutante (tz201) in vivo. Para medir atividades específicas de SOD (B), CAT (C), APX (D) e GPX (E) foram usados extratos destas mesmas linhagens, crescidas na presença e ausência de sacarose. C: plantas foram crescidas em meio sólido contendo 20 g.L $\mathrm{L}^{-1}$ de sacarose por 18 dias. Sem sacarose: plantas foram crescidas em meio sem sacarose por 18 dias. Os dados representam a média de valores de dois experimentos independentes e são mostrados como valores absolutos. Os valores são considerados significantemente diferentes quando $\mathrm{P} \leq 0.05$. 
Antioxidantes não-enzimáticos (ASC e GSH) também foram medidos em plantas selvagem (Ler) e mutante (tz-201) crescidas na condição controle. A linhagem mutante mostrou maior quantidade de ASC oxidado do que a linhagem selvagem (figura 29). Apesar da diferença de GSH observada não ser significativa estatisticamente entre as linhagens, é importante observar que há uma tendência da linhagem mutante apresentar mais GSH oxidado do que a linhagem selvagem.

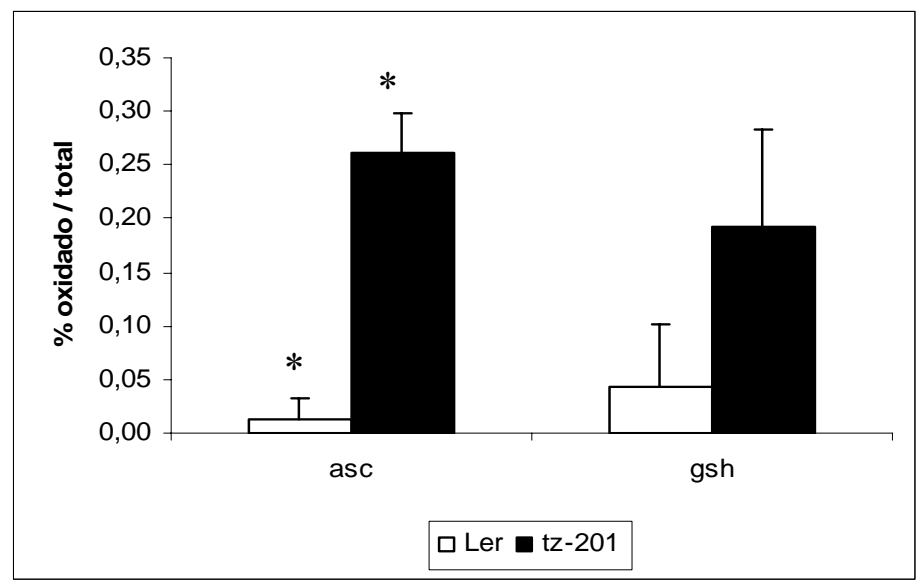

Figura 29: Ascorbato (ASC) e glutationa (GSH) foram quantificados usando A. thaliana selvagem (Ler) e mutante (tz-201) crescidas em meio sólido contendo 20 g.L $\mathrm{L}^{-1}$ de sacarose por 18 dias (condição controle). Os dados representam a razão da quantidade do composto oxidado sobre a quantidade do composto oxidado e reduzido. Os valores são considerados significantemente diferentes quando $\mathrm{P} \leq 0.05$.

\subsubsection{Perfil protéico}

Para verificar se havia proteínas expressas diferencialmente entre as linhagens selvagem (Ler) e mutante (tz-201) para o gene thi1, realizou-se análise proteômica de extratos protéicos destas 2 linhagens em colaboração com Breno Lourenzzo (IB-USP, SP), Dr. Jonas Perales (Fiocruz, RJ) e André Teixeira da Silva Ferreira (Fiocruz, RJ). Para extração das proteínas de A. thaliana foi utilizado o protocolo de extração descrito por WANG et al. (2006), modificado. Pode-se observar na figura 30, que o perfil protéico das amostras submetidas à análise proteômica mostrou-se intacto. 


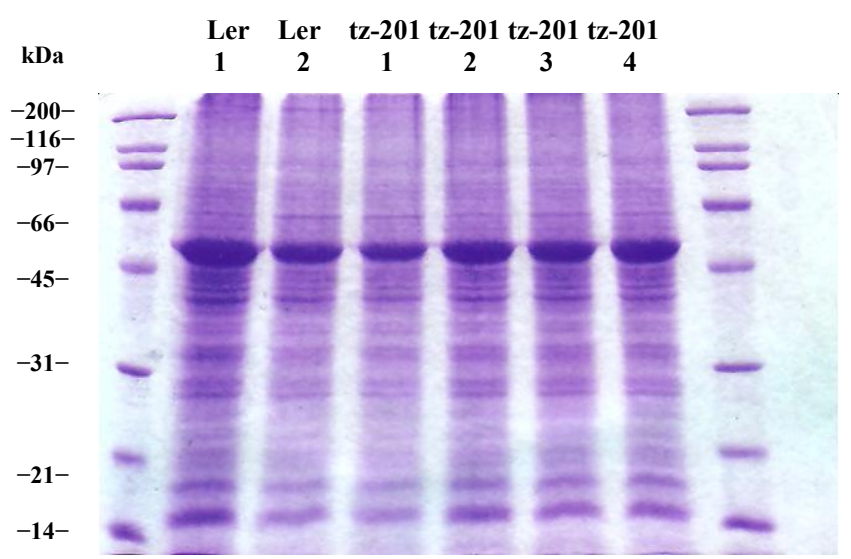

Figura 30: Perfil de proteínas extraídas de linhagens selvagem (Ler) e mutante (tz-201) de A. thaliana. Foram aplicados 40 ug de proteína total em gel de SDS-PAGE $12 \%$. Esse foi corado, posteriormente, com comassie blue R-250.

Proteínas das linhagens selvagem e mutante (quadruplicatas) foram separadas por gel bidimensional. Os géis foram escaneados e comparados entre si, pelo programa ImageMaster, quanto à porcentagem de volume ( $\%$ vol $)$ dos spots nas plantas selvagem e mutante. Os valores de cada spot foram comparados entre os diferentes géis. Spots que apresentaram diferenças de, pelo menos, 1,4x entre as linhagens, foram submetidos à análise estatística. Aqueles considerados estatisticamente diferentes entre si foram recortados do gel, a proteína foi eluída, digerida com tripsina e seqüenciada.

Quatro spots apresentaram diferenças significativas estatisticamente, como pode-se observar na figura 31A ( $a, b, c$ e $d)$. Destas 4 proteínas, 2 foram identificadas por espectrometria de massa (figura 31, spots $a$ e $b$; tabela 1). 
kDa

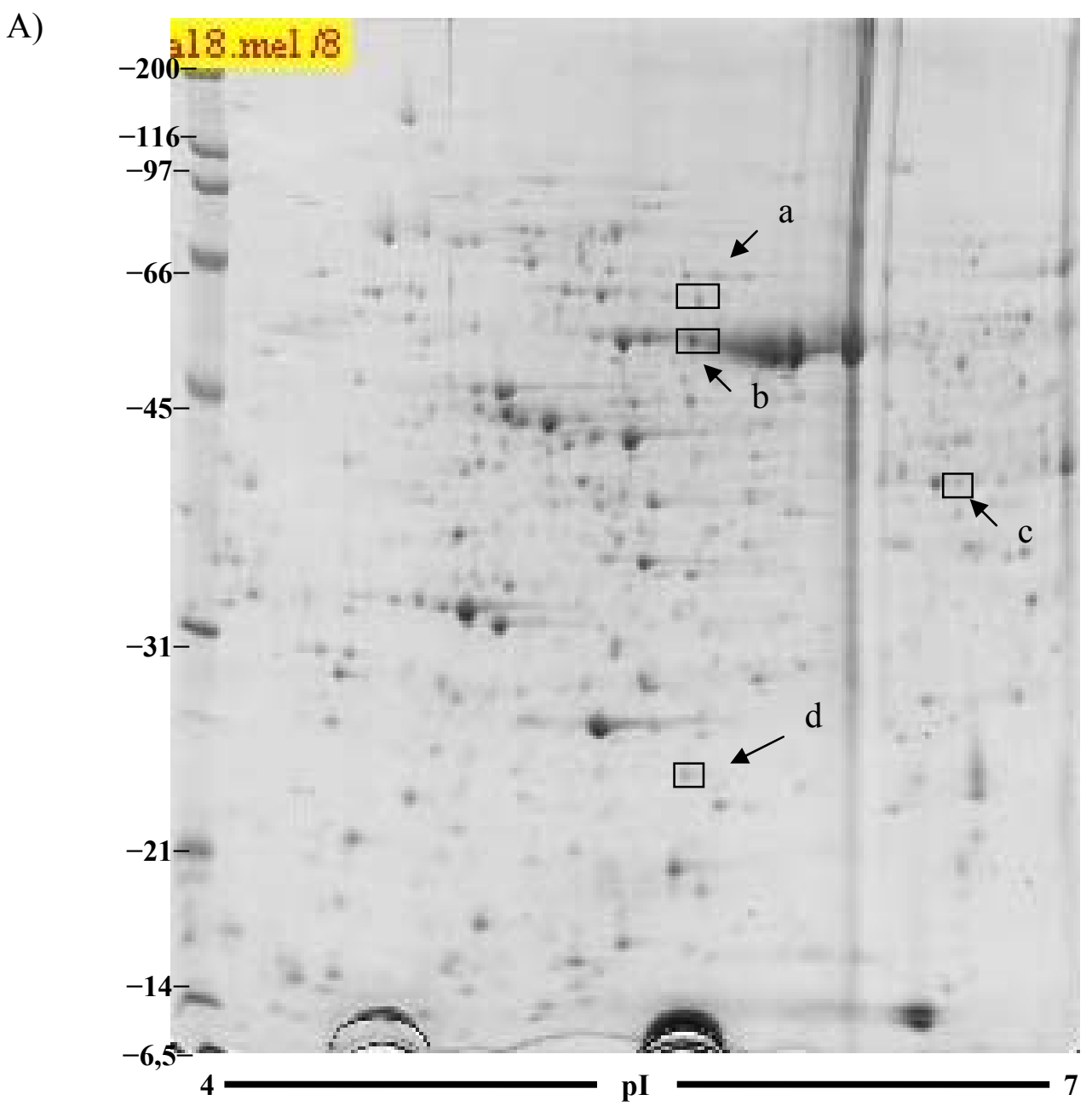

a)
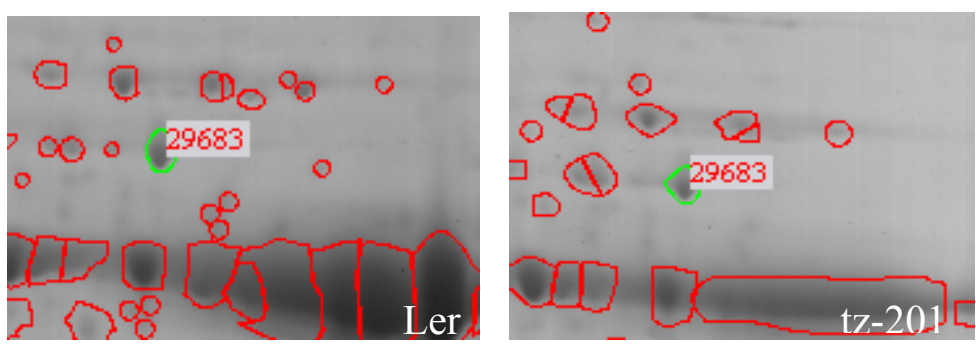

b)
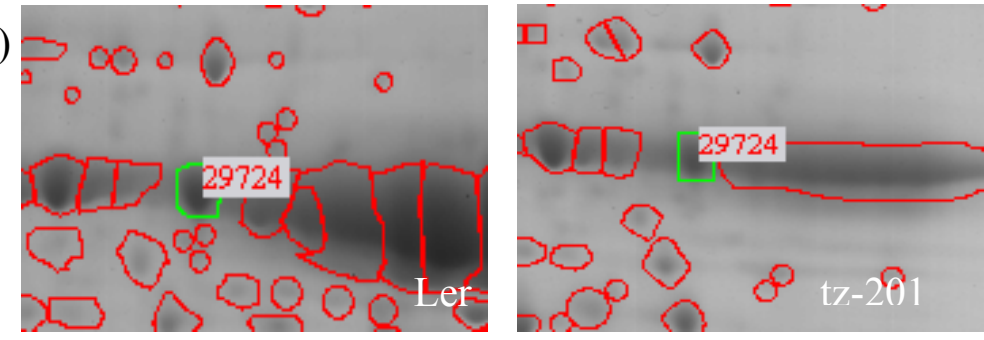
c)
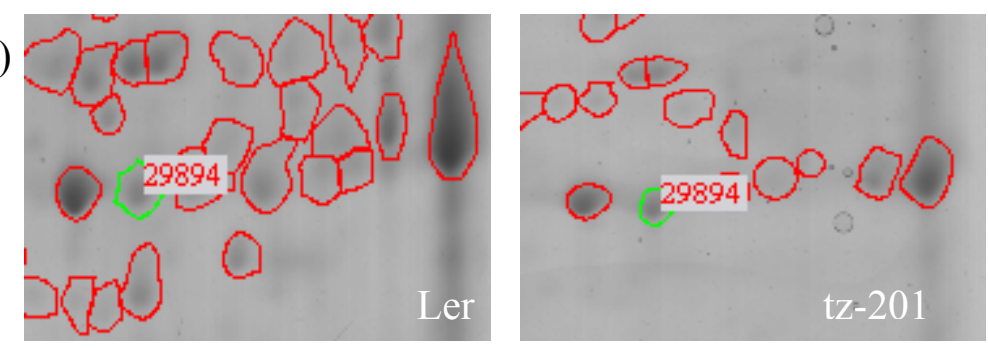

d)
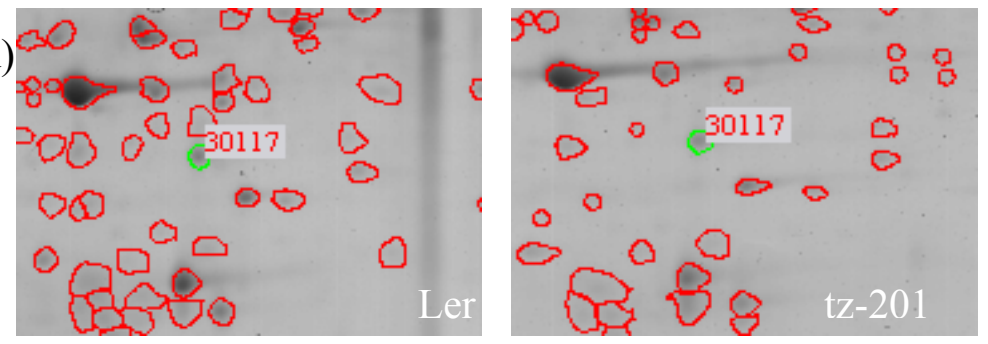

Figura 31: Eletroforese 2D de proteínas das linhagens selvagem (Ler) e mutante (tz201) de Arabidopsis thaliana. As proteínas foram separadas por gradiente linear de $\mathrm{pH}$ 4-7 e, posteriormente, separadas por SDS-PAGE. Os tratamentos foram comparados pelo software ImageMaster. A) As setas e os quadrados indicam proteínas (spots) que tiveram expressão alterada entre as linhagens analisadas. a, b, c e d) Detalhe dos spots "a, b, c e d", respectivamente, nas linhagens selvagem (Ler) e mutante (tz-201).

Todos os spots apresentaram-se em maior quantidade na linhagem mutante. $\mathrm{O}$ spot a (figura 31 a) apresentou aumento de 1,5 vezes, o $b$ (figura 31 b) e o $d$ (figura 31 d) de 1,4 vezes, e o $c$ (figura 31 c) de 2,2 vezes.

Como se pode observar na tabela 4 , a proteína referente ao spot a foi identificada como uma fosfoglicerato desidrogenase; a referente ao spot $b$ foi identificada como uma fosfopiruvato hidratase (enolase); e as referentes aos spots $c$ e $d$ foram seqüenciadas, mas não puderam ser identificadas. 
Tabela 4: Proteínas expressas diferencialmente em linhagens selvagem (Ler) e mutante (tz-201) de A. thaliana identificadas por espectrometria de massa.

\begin{tabular}{|c|c|c|c|c|c|c|}
\hline Spot & Proteína & $\begin{array}{l}\text { Número de } \\
\text { acesso } \\
\text { (GenBank) }\end{array}$ & $\begin{array}{c}\text { pI } \\
\text { Exp. }\end{array}$ & $\begin{array}{c}\text { Massa } \\
\text { Exp. } \\
\text { (kDa) }\end{array}$ & $\begin{array}{l}\text { Protein } \\
\text { score }\end{array}$ & Sequência Peptídica \\
\hline $\mathrm{a}$ & $\begin{array}{l}\text { Fosfoglicerato desidrogenase } \\
\text { (Arabidopsis thaliana) }\end{array}$ & $\frac{\text { gi } \mid 15235282}{(\mathrm{AT} 4 \mathrm{G} 34200.1)}$ & 6,16 & 63286 & 150 & $\begin{array}{l}\text { ILNDETFAK } \\
\text { GGVIDEDALVR } \\
\text { VIAHDPYAPADR } \\
\text { VGREVFESSHGR }\end{array}$ \\
\hline $\mathrm{b}$ & $\begin{array}{l}\text { Fosfopiruvato hidratase (enolase) } \\
\text { (Arabidopsis thaliana) }\end{array}$ & $\frac{\text { gi|15227987 }}{(\text { AT2G36530) }}$ & 5,45 & 47747 & 154 & $\begin{array}{l}\text { HIANLAGNPK } \\
\text { AGWGVMTSHR } \\
\text { AGWGVMTSHR+Oxidation } \\
\text { (HW) } \\
\text { MGVEVYHHLK } \\
\text { KAGWGVMTSHR } \\
\text { KAGWGVMTSHR+Oxidation } \\
\text { (HW) }\end{array}$ \\
\hline c & N.d. & - & - & - & - & - \\
\hline d & N.d. & - & - & - & - & - \\
\hline
\end{tabular}

pI exp. e Massa exp.: pI observado e Massa observada, respectivamente; N.d.: não determinada.

\subsubsection{Quantificação de danos no DNA}

O primeiro tesse realizado na padronização da quantificação de danos no DNA foi para verificar se o procedimento de extração de DNA genômico utilizado estava realmente extraindo DNA de mitocôndrias e cloroplastos. Para tanto, foram desenhados iniciadores que amplificariam fragmentos em torno de $800 \mathrm{pb}$, já que a amplificação de fragmentos de $8 \mathrm{~kb}$ (tamanho utilizado no experimento em si) não é trivial. Foram utilizados, então, para a amplificação de fragmento de cloroplasto, os iniciadores ClrepFpq e ClrepRpq (720pb), e para mitocôndria, os iniciadores MitrepFpq e MitrepRpq (748pb). Pode-se observar, na figura 32A, que o perfil de DNA genômico extraído para a QPCR mostra-se bastante adequado para ser aplicado nesta técnica já que não é observada degradação. Na figura 32B pode-se observar a amplificação dos fragmentos de mitocôndria e de cloroplasto esperados, o que indica que a extração de DNA organelar está sendo realizada da maneira correta. 


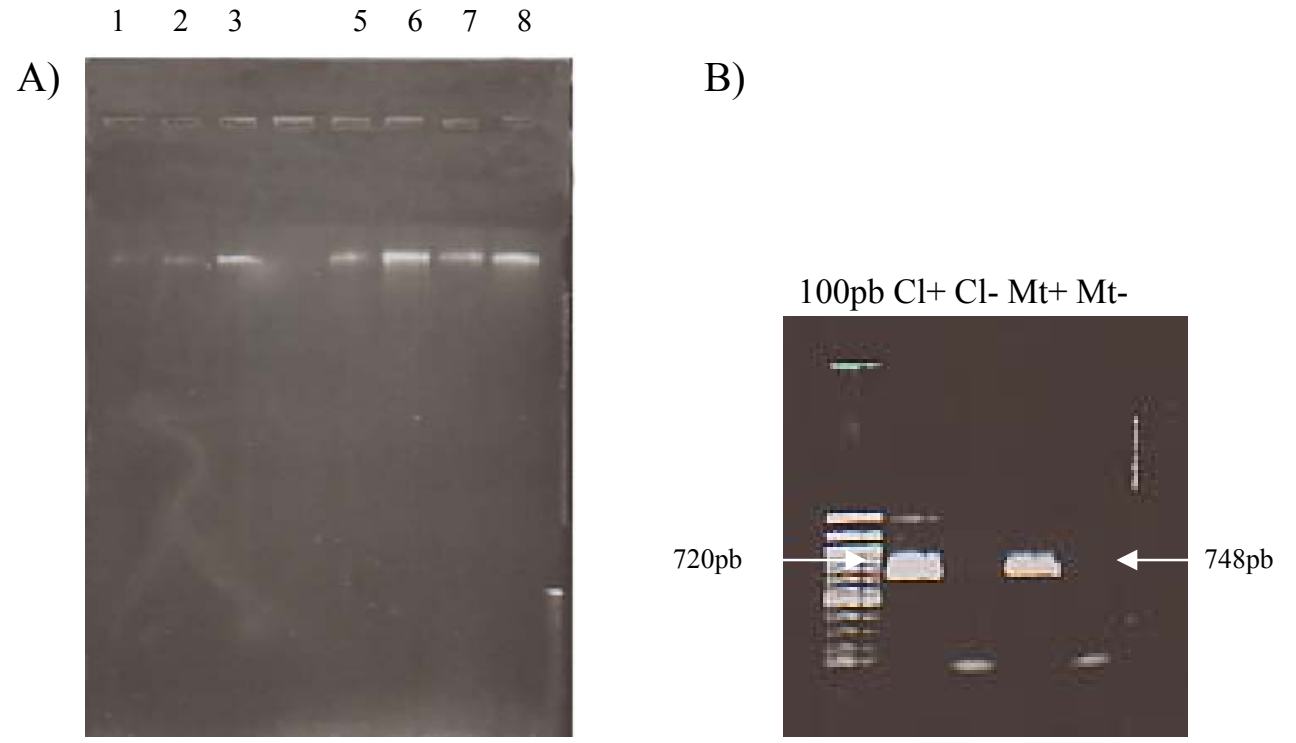

Figura 32: Quantificação de danos no DNA por PCR quantitativa (QPCR) usando como enzima elongase (Invitrogen). A) Perfil do DNA genômico a ser utilizado na quantificação de danos. Raias 1,2 e 3 são referentes a $1 \mathrm{ng} / \mathrm{uL}, 2 \mathrm{ng} / \mathrm{uL}$ e $5 \mathrm{ng} / \mathrm{uL}$ de $\lambda$ DNA, respectivamente; raias 5, 6, 7 e 8 mostram o perfil do DNA genômico a ser utilizado na quantificação de danos. B) Raia 1: padrão de peso molecular de $100 \mathrm{pb}$ (New England Biolabs); raia 2: Fragmento amplificado de 720 pb de cloroplasto; raia 3: Controle negativo utilizando-se iniciadores para cloroplasto; raia 4: Fragmento amplificado de $748 \mathrm{pb}$ de mitocôndria; raia 5: Controle negativo utilizando-se iniciadores para mitocôndria.

Iniciou-se, então, o processo de escolha dos melhores iniciadores para amplificar fragmentos do genoma nuclear de tamanho maior ou igual a $8 \mathrm{~Kb}$. Dentre os numerosos pares utilizados estão os iniciadores Ara5 e R11. Utilizando-se sempre a enzima, rTth DNA polymerase XL, testou-se o gradiente gradiente de temperatura (de $38,5^{\circ} \mathrm{C}$ a $41,5^{\circ} \mathrm{C}$ ), com 25 ciclos. Foi feito um gel de poliacrilamida (mais sensível que o de agarose) e foi observada somente uma banda, como mostrado na figura 33A. A melhor temperatura foi a de $39,7^{\circ} \mathrm{C}$. A temperatura, então, foi fixada e testou-se o melhor número de ciclos que, aparentemente estaria entre 27 e 30 . Foi feito um gel com as amostras cujas PCRs foram submetidas a diferentes números de ciclos e foram encontradas diversas bandas (figura 33B). Várias das condições foram modificadas, inclusive os iniciadores (com Tms maiores), mas sempre foi observada mais de uma banda. 
Para a amplificação de DNA de cloroplasto, foram utilizados os iniciadores ClrepFgd e ClrepRgd e foi feito um gradiente de temperatura de $54^{\circ} \mathrm{C}$ a $60,8^{\circ} \mathrm{C}$. Os produtos de PCR foram aplicados em um gel de poliacrilamida (figura 33C) e foi possível observar uma banda única. Escolheu-se a temperatura de $54,9^{\circ} \mathrm{C}$, pois era a temperatura mais alta onde ainda observava-se uma banda (maior especificidade). $\mathrm{O}$ melhor número de ciclos foi 29 , como pode ser observado na figura 33D.

Não foi possível obter a amplificação de fragmentos grandes de DNA mitocondrial utilizando os iniciadores MitrepFgr e MitrepRgr (8.769pb). Testaram-se diversas condições como gradientes de temperatura, alterações na concentração de magnésio, alterações no número de ciclos e na quantidade da polimerase e, mesmo com as alterações, não foi possível amplificar o fragmento utilizando nenhum dos pares de iniciadores utilizados.

Foram padronizamos, então, a melhor temperatura e o melhor número de ciclos para os fragmentos menores (de aproximadamente 100pb) de cloroplasto e mitocôndria, utilizando os iniciadores Chloleftprimer e LtCHLOrv (115pb) para amplificar cloroplasto, e Mitleftprimer e LtMITrv (131pb) para mitocôndria. A melhor temperatura tanto para mitocôndria quanto para cloroplasto foi de $65^{\circ} \mathrm{C}$ e o melhor número de ciclos, também para ambos, foi 27. Em ambos os casos foi observada uma única banda. 


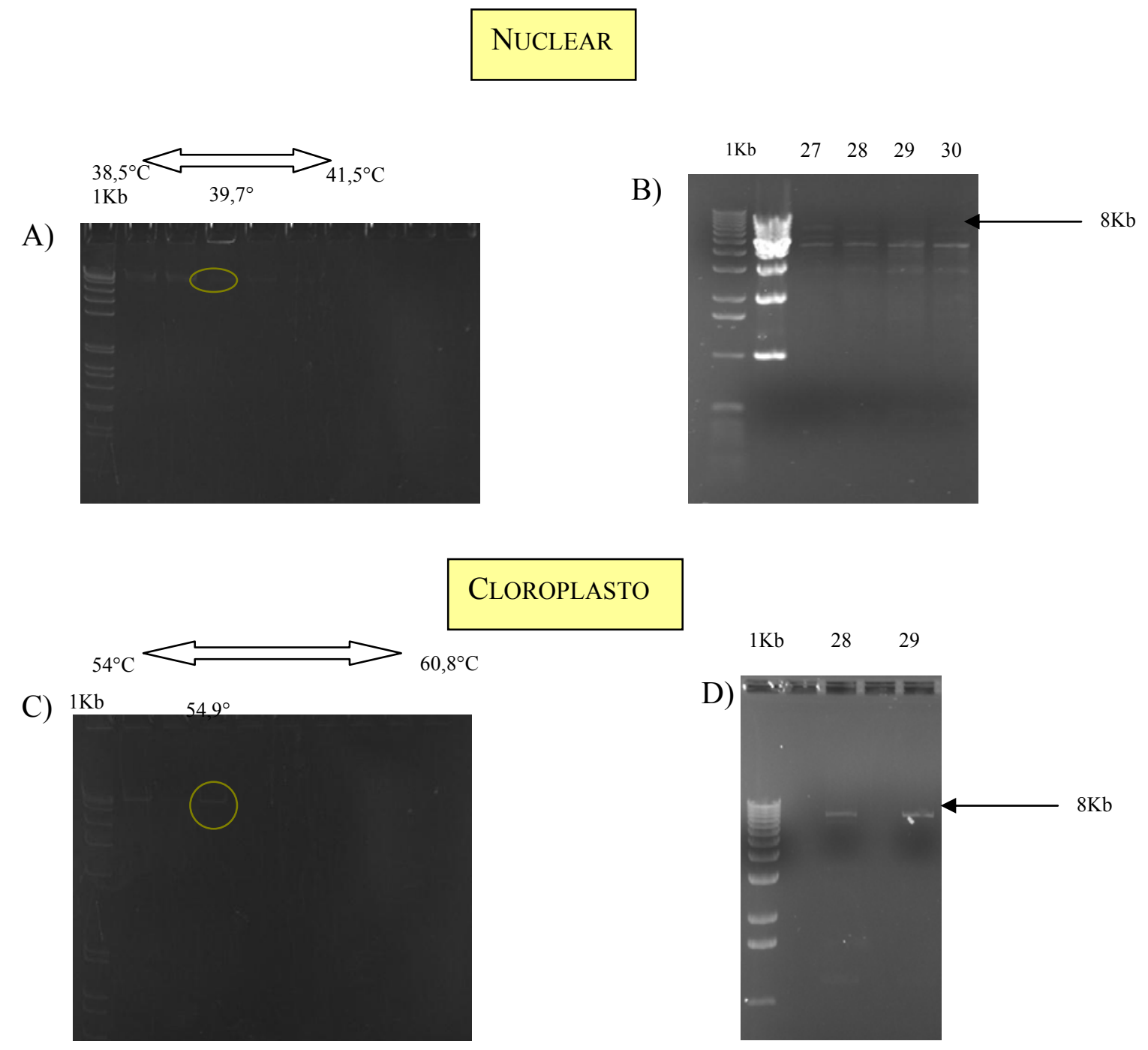

Figura 33: Quantificação de danos no DNA por PCR quantitativa (QPCR) usando como enzima Polymerase rTthXL (Applied). A) Raia 1: padrão de peso molecular de $1 \mathrm{~Kb}$ (Invitrogen); Raias 2 a 7: produto de PCR com temperaturas de anelamento de, respectivamente $38,5,39,1,39,7,40,3,40,9$ e $41,5^{\circ} \mathrm{C}$, e submetidas a 25 ciclos. B) Raia 1: Padrão de peso molecular de $1 \mathrm{~Kb}$ (Invitrogen); raias 3 a 6: produtos de PCR com temperatura de anelamento de $39,7^{\circ} \mathrm{C}$, submetidas a $27,28,29$ e 30 ciclos. C) Raia 1: padrão de peso molecular de $1 \mathrm{~Kb}$ (Invitrogen); Raias 2 a 9: produtos de PCR com temperaturas de anelamento de, respectivamente 54, 54,2, 54,9 56, 57,2 58,4, 59,6 e $60,8^{\circ} \mathrm{C}$, e submetidas a 20 ciclos. D) Raia 1: Padrão de peso molecular de $1 \mathrm{~Kb}$ (Invitrogen); raias 3 e 5, repspectivamente: produtos de PCR com temperatura de anelamento de $54,9^{\circ} \mathrm{C}$, submetidas a 28 e 29 ciclos.

O DNA de cloroplasto foi o único em que conseguimos amplificar o fragmento grande e o pequeno, ambos apresentando uma única banda. Foram utilizados, então, os pares de iniciadores e as condições pré-estabelecidas para quantificar danos no DNA de cloroplasto. As amostras foram diluídas a uma concentração inicial de $10 \mathrm{ng} / \mathrm{uL}$ e foi 
feita a quantificação de DNA usando-se picogreen (invitrogen). Em seguida, as amostras foram diluídas a uma concentração final de $2 \mathrm{ng} / \mathrm{uL}$ e foram utilizados $5 \mathrm{uL}$ (10ng) nas reações de PCR. Como pode ser observado na figura 34, nota-se uma maior quantidade de danos na linhagem mutante em relação à selvagem, submetida a $0,1 \%$ de peróxido de hidrogênio. Não foi observada diferença significativa entre as linhagens estudadas submetidas a $0,05 \%$ de peróxido de hidrogênio.

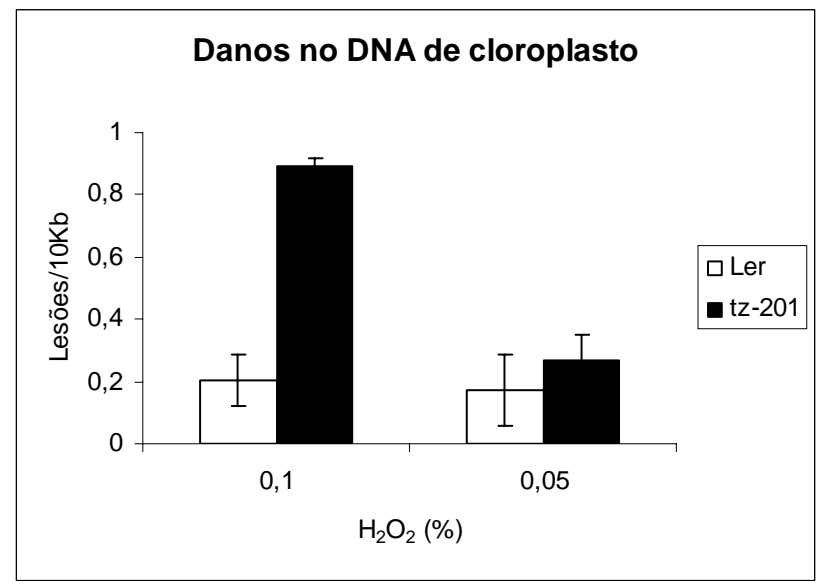

Figura 34: Quantificação de danos no DNA por PCR quantitativa (QPCR). Plantas das linhagens selvagem (Ler) e mutante (tz-201) foram submetidas a $0,1 \%$ e $0,05 \%$ de peróxido de hidrogênio e submetidas à QPCR para a quantificação de danos em cloroplastos. Os dados foram normalizados pela amplificação do fragmento de, aproximadamente, $100 \mathrm{pb}$.

\subsubsection{Tiamina}

Iniciamos o processo de padronização da quantificação de tiamina livre (T), monofosfato (TP) e pirofosfato (TPP).

Inicialmente foram testados diferentes protocolos de extração de tiamina. Apesar de haver um protocolo de extração de tiaminas em algas (PINTO et al, 2002) o que se mostrou mais adequado às plantas foi o de MANCINELLI et al (2003), modificado (como mostrado no item 3.12.), que realiza a extração de tiamina em sangue humano. No início dos tesses, foram utilizadas plantas selvagens crescidas em meio com tiamina, já que se pretendia extrair tiaminas da linhagem mutante e esta é auxotrófica a esta vitamina. Nestas condições não foram observadas tiaminas (dados não mostrados). Resolveu-se, 
então, crescer as plantas selvagens em meio sem tiamina. Continuou-se sem observar esta vitamina (dados não mostrados). Ao mesmo tempo, foi constatado que a linhagem mutante consegue se desenvolver em meio sem tiamina por 18 dias, o tempo de crescimento das plantas utilizado nos experimentos, usando, provavelmente, tiamina endógena proveniente ainda das reservas da semente. Resolveu-se testar, então, plantas mutantes crescendo em meio sem tiamina.

$\mathrm{Na}$ figura 35A pode-se observar, em preto, um pico referente ao ferrocianeto de potássio, já que nesta situação foram aplicados somente os componentes da reação, sem tiaminas (sem amostras ou padrões). Em rosa, pode-se observar os padrões de tiamina T, TP e TPP aplicados juntos.
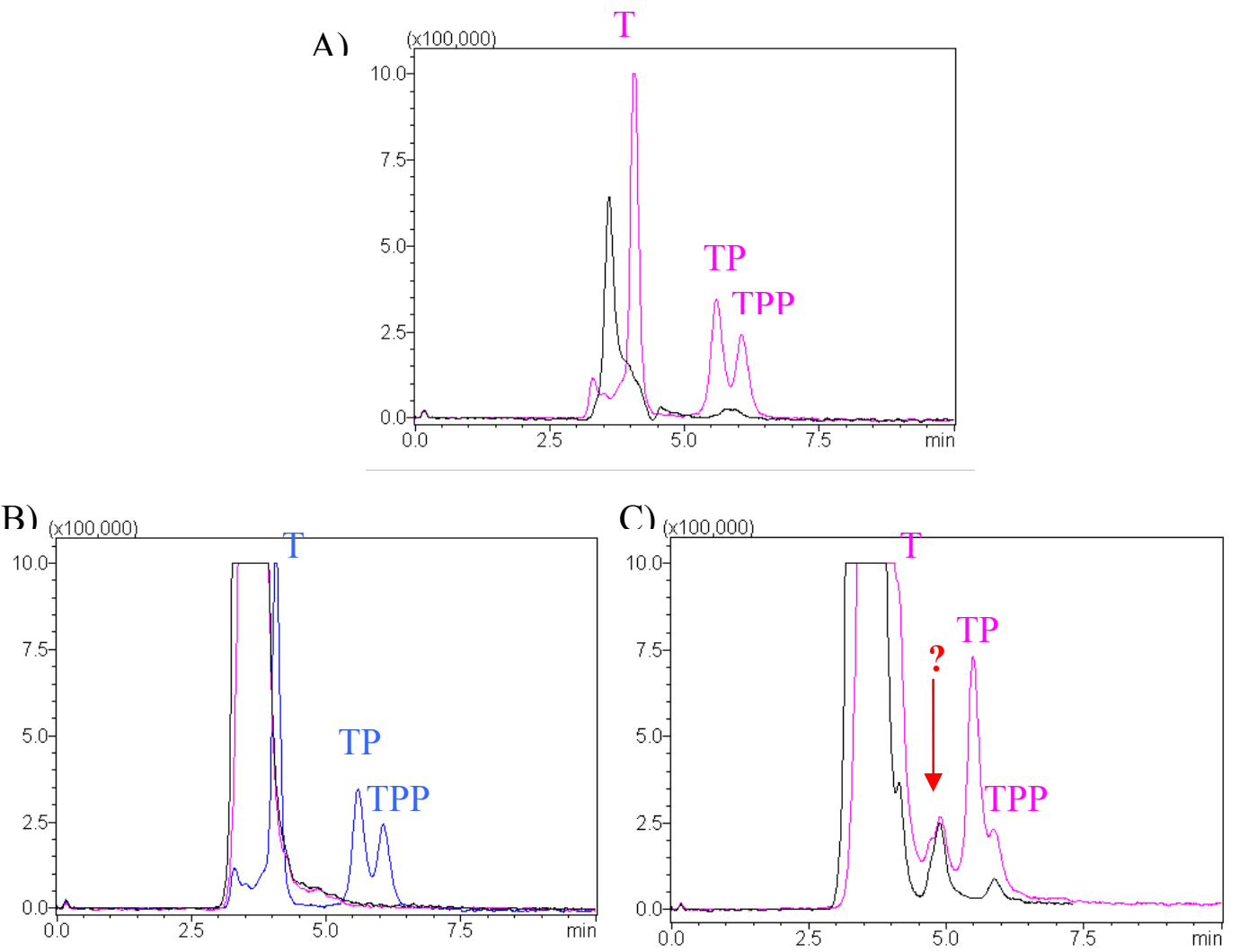

Figura 35: Extração e quantificação de tiamina e de seus ésteres fosfatos, a partir das linhagens selvagem (Ler) e mutante (tz-201) de A. thaliana. A) Em rosa, padrões de tiamina livre (T), monofosfato (TP) e pirofosfato (TPP); e, em preto, pode-se observar um pico referente aos componentes da derivatização sem tiaminas $\left(\mathrm{K}_{4} \mathrm{Fe}(\mathrm{CN})_{6}\right)$. B) Em rosa e preto, duas amostras independentes de A. thaliana do ecótipo selvagem crescidas em meio sem tiamina; em azul, padrões de tiamina. C) Duas amostras independentes de 
A. thaliana da linhagem tz-201 crescidas em meio sem tiamina; em preto, sem contaminar a amostra com TP exógena e, em rosa, contaminando a amostra com TP exógena.

Duas amostras independentes da linhagem selvagem (figura 35B) apresentaram um pico (rosa e preto) que, a princípio, não é equivalente ao pico de tiamina, mas sim ao do ferricitocromo (antes do pico da tiamina livre). Por outro lado, na figura 35C, podese observar tiaminas de duas amostras independentes da linhagem mutante. Uma das amostras da linhagem mutante (figura 35C, curva rosa) foi contaminada com TP exógena antes da extração e a outra não (curva preta). Na que não foi contaminada, pode-se observar um pico de T, um de TPP e um pico desconhecido (seta vermelha). Na que foi contaminada com TP, pode-se observar todas as tiaminas e esse mesmo pico desconhecido. 


\section{Discussão}

\subsection{Modulação da expressão do gene thi1 em A. thaliana}

O promotor do gene thi1 é modulado por luz conforme documentado por RIBEIRO et al (2005). Do mesmo modo, esses pesquisadores observaram que o promotor de thi1 é responsivo à ausência de açúcar. $\mathrm{O}$ estudo foi realizado através do uso de fusões contendo a região promotora do gene thi1 a montante do gene uidA, que codifica para a enzima $\beta$-glucuronidase (GUS). A expressão do gene GUS em plantas Pthi608 crescidas em meio sem sacarose e coletadas em diferentes horários (figura 18B) estão em concordância com o perfil de expressão de RNAm thi1 de plantas coletadas em diferentes horários (figura 18A). O aumento na expressão de RNAm thi1, com pico as 3 pm, parece acompanhar o processo fotossintético. A indução da expressão do gene nesse momento é coerente com o fato de que o tiazol, em plantas, é sintetizado nos cloroplastos (Julliard \& DouCE, 1991; Belanger et al, 1995) a partir de moléculas simples entre elas produtos imediatos do ciclo de Calvin. Por outro lado, pode ser considerado o fato de que a tiamina na forma TPP é necessária a diversas enzimas do metabolismo fotossintético. As $3 \mathrm{pm}$, momento em que está ocorrendo intensa taxa fotossintética, os cloroplastos estão em plena atividade nas folhas, onde verifica-se a maior expressão do promotor thi1. As 12 am e as 6 pm, a expressão é homogeneamente distribuída, já que não é o momento de maior incidência de luz, e as 9 am e 9 pm, com menor incidência solar, há menor expressão de RNAm thi1. As 6 pm, após intensa expressão de RNAm thi1 as 3 pm, a proteína THI1 deve ser enviada para a raiz, que depende da tiamina produzida em tecidos fotossintéticos (RIBEIRO et al., 2005). BELANGER et al (1995) já haviam observado que a expressão de thi1 de milho é regulada ao longo do desenvolvimento e também em nível tecidual. 
Não foram observadas diferenças na expressão do gene GUS em plantas Pthi608 crescidas em meio com sacarose (dados não mostrados). Plantas crescidas em meio com sacarose devem apresentar uma taxa fotossintética reduzida em relação àquelas crescidas em meio sem sacarose uma vez que já possuem o produto da fotossíntese disponível. A modulação da expressão do gene thi1 acompanhando os picos fotossintéticos em plantas crescidas em meio sem sacarose pode ser importante para a manutenção da homeostase. O estudo do perfil de acúmulo da proteína THI1 nos tecidos acompanha a expressão do RNAm thi1 com um deslocamento de 2 horas após o acúmulo do mensageiro. Esses resultados sugerem que o controle primário da expressão do gene thi1 é prioritariamente em nível transcricional.

Foi realizada uma série de experimentos a fim de se analisar a expressão de RNAm thi1, por RT-qPCR (figura 17), e a produção da proteína THI1, por slot blot (figura 20), em linhagens selvagem, mutante e transgênicas, e confirmamos que as linhagens obtidas por KASHIWABARA (2003) apresentam, respectivamente, uma redução de $2 \mathrm{x}$ na expressão do gene na linhagem thi $1_{a s} a$ e, contrariamente, aumento de $10 \mathrm{x}$ nas plantas transgênicas thi1 $a$ (figura 17) quando comparadas com a expressão de thi1 nas linhagens selvagem (Ler) e mutante (tz-201). Esta duas linhagens não apresentaram alteração na expressão entre si. Esses resultados nos indicam que as linhagens transgênicas thi $1_{s} a$ e thi $1_{a s} a$, superexpressam ou expressam menos, respectivamente, que as linhagens selvagem e mutante. A superexpressão e a menor expressão de thi1 pelas linhagens thi $1_{s} a$ e thi $1_{a s} a$, respectivamente, podem não provocar grandes alterações fisiológicas nas respectivas linhagens, já que no primeiro caso haveria mais RNA disponível e no segundo caso, menos RNA disponível, entretanto capaz de produzir uma proteína funcional em quantidade suficiente para manter as funções vitais da linhagem thi1 ${ }_{a s} a$. 
A análise da proteína THI1 por slot blot indica que o anticorpo primário liga-se especificamente à proteína THI1, já que não foi observada nenhuma banda no controle negativo (figura 20). Comparando a intensidade das bandas, foi observado que as linhagens mutante e senso apresentam quase metade da quantidade de THI1 que as linhagens selvagem e antisenso.

Riboswitches são regiões conservadas do RNAm que ligam metabólitos específicos diretamente sem a necessidade de uma proteína e regulam a expressão gênica (CROFT et al, 2007). Há diversos mecanismos de riboswitches que alteram a expressão gênica, incluindo alteração do sítio de ligação de ribossomos (controle da tradução), formação de "hairpins" (controle da transcrição), splicing alternativo (controle de splicing), ou ligação adjacente à cauda poliA (controle de processamento / estabilidade) (THORE et al, 2006; SUDARSAN et al., 2003). Foi descrito riboswitch entre TPP e RNAm thiC em A. thaliana (THORE et al, 2006) e entre TPP e RNAm THIC e THI4 em Chlamydomonas reinhardtii, o primeiro envolvido na síntese de pirimidina e o segundo na síntese de tiazol (CROFT et al., 2007). A análise de expressão de RNAm thi1 e de produção da proteína THI1 sugerem que sua expressão não seja regulada por "riboswitches".

Comparando a intensidade das bandas de proteína referentes às amostras em relação ao controle positivo foi possível deduzir que de $0,5 \%$ a $1 \%$ das proteínas presentes nos extratos de A. thaliana é proteína THI1 (figura 20). FAOU \& TROPSCHUG (2004), mostraram que todas as isoformas juntas de CyPBP37, proteína ortóloga a THI1 em Neurospora crassa, representa de $1 \%$ a 1,5\% das proteínas totais. Esta grande quantidade de proteína THI1 presente no extrato total protéico mostra a importância funcional desta proteína provavelmente devido ao seu envolvimento em síntese de tiamina, cofator envolvido em pontos metabólicos chaves, além de ser necessária para o 
processamento de metabólitos geradores de ROS. Outra possibilidade é que a proteína THI1 tenha uma meia vida curta sendo rapidamente degradada.

Um dos aspectos originais do presente trabalho é a determinação de que há uma modulação entre manhã e tarde na expressão do gene thi1 e subseqüente acúmulo da proteína. Em função destas observações elaborou-se um experimento para avaliar se o gene thi1 estaria sob o controle de relógio biológico. Ritmos sincronizados por ciclos de dia/noite na Terra são observados em todos os organismos, no metabolismo, na fisiologia, ou mesmo no comportamento. Em plantas, tais ritmos têm sido detectados em nível fisiológico para numerosos processos, tais como fechamento de flores ou folhas, movimento dos cloroplastos, capacidade fotossintética, condutância estomática, divisão celular e muitos outros. Muitos genes envolvidos em processos fotossintéticos e alocação de carbono (como é o caso de thi1) são regulados de maneira circadiana (LOIVAMÄKI et al., 2007). Esses eventos, entretanto, não são simples respostas a ambientes externos e continuam sob condições constantes (LOIVAMÄKI et al., 2007). Para verificar se thi1 está sob controle de relógio circadiano, as plantas foram submetidas a crescimento em claro contínuo. Se fosse um ritmo endógeno, essa característica permaneceria sob condições constantes. Na figura 19, condição CC (curso livre), foi observado um padrão bastante parecido com aquele da condição CE. Puderam ser observados três picos próximos àqueles da condição controle, ligeiramente fora de fase. Como em ambas as condições foram observadas flutuações rítmicas, com picos coincidentes, é possível que o gene thi1 possa ser regulado de maneira circadiana. $\mathrm{O}$ período do primeiro ciclo em condições constantes é chamado período de transição, em que o ritmo pode não estar bem definido. O período de curso livre é próximo, mas pode não ser exatamente 24 horas. O desvio do período de curso livre de exatamente 24 horas é considerado uma evidência de que o ritmo biológico está sob controle de um sistema 
endógeno de medição de tempo, o qual necessita ser ajustado por fatores ambientais para sincronizar-se com o tempo solar (FETT-NeTO, 2004). Os resultados obtidos sugerem, portanto, que a expressão do gene thi1 está sob o controle do relógio biológico.

PAPINI-TERZI et al (2003) observaram que plantas transferidas para o escuro total por 2 dias antes da extração de RNA apresentaram redução no acúmulo de RNAm thi1. Quando as plantas retornaram à luz, a expressão de RNAm thi1 voltou a aumentar. RIBEIRO et al (2005) confirmaram os dados anteriores ao fazer a análise funcional da região promotora de thi1, por meio da construção de uma série de cassetes da região promotora fusionada ao gene repórter GUS para determinar o padrão de expressão e a responsividade a diversas condições. Plantas submetidas a 11 dias de escuro apresentaram níveis reduzidos de atividade de GUS. Quando elas foram transferidas para o claro houve aumento na atividade de GUS. Além disso, RIBEIRO et al (2005) observaram na região promotora motivos ligantes de fatores de transcrição, como MYB, SBF-1 e GT-1, relacionados a controle por luz e sugerem que a regulação da região promotora de thi1 depende da interação de todos esses fatores. Esses resultados, juntamente com aqueles observados na figura 19, fortalecem a hipótese de que esse gene seja regulado por luz.

\subsection{Aspectos bioquímicos e fisiológicos associados ao gene thi1}

PAPINI-TERZI (2000) observou, após 9 meses de estocagem das sementes, queda na germinabilidade em sementes da linhagem mutante em relação as do ecótipo selvagem. KASHIWABARA (2003) observou, após 10 meses de estocagem, que a linhagem antisenso apresentou menor taxa de germinação do que a linhagem senso, mesmo com suplementação de tiamina. Como os dois autores fizeram os experimentos em diferentes condições, esses foram repetidos utilizando-se as linhagens selvagem, 
mutante, senso e antisenso, ao mesmo tempo, nas mesmas condições. As sementes das linhagens transgênicas apresentaram maior viabilidade, enquanto as do ecótipo selvagem apresentaram viabilidade intermediária e as da linhagem mutante apresentaram menor viabilidade (figura 22). Os resultados sugerem que as sementes da linhagem mutante são menos resistentes a longos períodos de dessecamento. Sabe-se que sementes quiescentes apresentam degradação progressiva de moléculas biológicas, incluindo DNA e RNA (ELDER et al, 1987). Uma correlação direta entre redução de viabilidade de sementes e perda de integridade do DNA foi estabelecida em estudos que confirmam o aumento de aberrações cromossômicas e mutações pontuais em sementes quiescentes (MURATA et al, 1982). Embora não seja conhecida a estrutura exata e o estado de hidratação do DNA em sementes secas, espera-se que sementes estocadas por longos períodos, sem reparo de DNA, possam progressivamente acumular sítios abásicos e outras lesões geradas espontâneamente. Ao mesmo tempo, a quantidade de danos causados em sementes mais velhas pode exceder a capacidade de reparo das plântulas em desenvolvimento (BRITT, 1996). Isto é confirmado por outros estudos em que plantas mutantes, com deficiência em reparo de DNA, produzem sementes com menor viabilidade do que plantas selvagens (LIU et al, 2000; CostA et al, 2001). De qualquer forma, no momento da germinação, mecanismos de reparo são ativados de modo a garantir o estabelecimento da plântula (OSBORNE, 1986). Um dos fatores que contribuem para a redução de viabilidade de sementes é o acúmulo de ROS (CARDOSO, 2004) devido a retomada da atividade metabólica. Considerando que, naturalmente, há radicais livres, esses tenderiam a causar danos no DNA. A linhagem mutante, que possui uma mutação pontual no gene thi1, produziria proteína THI1 defectiva, e a ausência de sua funcionalidade afetaria o metabolismo celular aumentando a produção de ROS (figura 36) e, portanto, reduzindo a taxa de germinação do embrião. A linhagem 
thi $1_{s} a$ produziria maior quantidade de proteína THI1, não ocorrendo desbalanço metabólico, enquanto a thi $1_{a s} a$ produziria THI1 em menor quantidade, mas suficiente para que não ocorra alterações metabólicas significativas.

Como o gene thi1 está envolvido em síntese de tiamina, cofator presente em várias vias metabólicas, foram quantificados carboidratos de baixo peso molecular nas linhagens selvagem (Ler) e mutante (tz-201) para verificar se, mesmo com as plantas crescendo em meio com tiamina, haveria diferenças entre as duas linhagens. A linhagem mutante apresentou aumento na quantidade de sacarose e diminuição na quantidade de açúcares livres (glicose e frutose) em relação à linhagem selvagem (figura 24A).

Diferenças observadas na relação sacarose e hexoses livres entre as linhagens (figura 24B) podem ser devido à produção diferencial de enzimas responsáveis pela síntese e catabolismo de sacarose. A sacarose é um dissacarídeo em que glicose e frutose são unidos via ligação glicosídica. A clivagem da sacarose é catalisada por duas enzimas: a invertase e a sacarose sintase. A invertase cliva a sacarose em dois monossacarídeos (glicose e frutose), enquanto a sacarose sintase, na presença de UDP, converte sacarose em UDP-glicose e frutose (STURM \& TANG, 1999). Foi mostrado recentemente que a expressão citossólica de uma invertase em tubérculos de batata leva a uma redução de $95 \%$ na quantidade de sacarose acompanhada por um grande acúmulo de glicose e redução na quantidade de amido (TRETHEwEY et al, 1998).

A quantificação de massa fresca nas linhagens selvagem e mutante de $A$. thaliana, com idades de 3 a 6 semanas permitiram determinar que a linhagem mutante possui, após 6 semanas, maior massa fresca de planta inteira (figura 23A) e de raízes (figura 23C), enquanto a linhagem selvagem possui maior massa fresca de folhas (figura 23B). Na linhagem mutante, em que THI1 não é funcional, parece ocorrer acúmulo de precursores da síntese de tiazol, entre eles gliceraldeído 3-fosfato (G3P). G3P está envolvido na síntese de sacarose. O excesso de sacarose, que é o açúcar mais 
comumente translocado no floema, é desviado para tecidos não fotossintéticos, como a raiz. Isso, por fim, aumentaria a massa fresca local por contribuir com a retenção de água nos tecidos, já que se trata de uma substância osmoticamente ativa.

Para verificar se a linhagem mutante, com produção da proteína THI1 defectiva, alteraria a expressão de antioxidantes em relação à linhagem selvagem, foram quantificados peróxido de hidrogênio, antioxidantes enzimáticos e não-enzimáticos nas linhagens citadas acima. Como RiBEIRO et al (2005) observou que o promotor de thi1 é modulado por luz e é responsivo à ausência de açúcar e hipoxia, foram utilizadas como condições experimentais alterações de fotoperíodo, crescimento das plantas na ausência de sacarose e hipoxia.

Em plantas submetidas a diferentes condições luminosas, observou-se, no geral, maior atividade de CAT, SOD e GPX na linhagem mutante, enquanto foi observado maior atividade de APX na linhagem selvagem (figura 26). De acordo com MiTTLER (2002), ascorbato peroxidase (APX) seria responsável pela fina modulação de ROS para sinalização, enquanto CAT seria responsável pela remoção do excesso de ROS durante estresse. Portanto, a maior atividade de APX na linhagem selvagem está relacionada, provavelmente, à sinalização e não à detoxificação de peróxido de hidrogênio.

SOD age convertendo $\mathrm{O}_{2}{ }^{\bullet-}$ em $\mathrm{H}_{2} \mathrm{O}_{2}$ (figura 12) e, APX e CAT detoxificam $\mathrm{H}_{2} \mathrm{O}_{2}$. APX requer ascorbato como intermediário para a liberação de $\mathrm{H}_{2} \mathrm{O}$ (figura 14), enquanto CAT converte $\mathrm{H}_{2} \mathrm{O}_{2}$ diretamente em $\mathrm{H}_{2} \mathrm{O}$ e $\mathrm{O}_{2}$ (figura 13). GPX reduz peróxido de hidrogênio ou alquil hidroperóxidos utilizando glutationa (figura 15). O balanço entre as atividades de SOD e CAT nas células é crucial para manter uma quantidade adequada de radicais superóxido e $\mathrm{H}_{2} \mathrm{O}_{2}$ (MITTLER, 2002), enquanto APX é responsável pela fina modulação de ROS para sinalização. Em mamíferos, GPX tem o papel de proteger as células contra danos oxidativos (IQBAL et al., 2006). É natural, 
então, observamos aumento na atividade de CAT e GPX se foi observado aumento na atividade de SOD, já que estas duas enzimas detoxificam o produto da reação de SOD.

O aumento na atividade de CAT e SOD na condição CE é coerente com o fato de que as taxas de respiração em geral são maiores no escuro do que na luz. A enzima piruvato desidrogenase, que converte piruvato a acetil-Coa no ciclo de Krebs, apresenta no claro $25 \%$ de sua atividade no escuro (BUDDE \& RANDALL, 1990). Além disso, a cadeia de transporte de elétrons mitocondrial é um dos grandes responsáveis por produção de ROS. Parece que os 2 dias em que as plantas permanecem no fotoperíodo 12h após retornarem do escuro total na condição CEC (figura 26) não são suficientes para o metabolismo da planta retornar à condição normal e estas alterações metabólicas sejam suficientes para desencadear grande produção de ROS. Como resultado as plantas da linhagem mutante, que produzem a proteína THI1 defectiva, superexpressam enzimas antioxidantes.

Deficiência de oxigênio nas células é chamada de hipoxia quando os níveis de oxigênio diminuem a intensidade da respiração mitocondrial (DREW, 1997). O principal efeito da hipoxia é a redução na disponibilidade de $\mathrm{O}_{2}$ na região submersa da planta devido à menor difusão de gases na água em relação ao ar (DAT et al, 2004). Sob hipoxia, a pressão parcial de $\mathrm{O}_{2}$ limita a produção de ATP por fosforilação oxidativa. A glicólise é responsável pela maior porcentagem de produção de ATP sob condições normóxicas. Mudanças metabólicas e de desenvolvimento são estimuladas resultando na adaptação a ambientes com baixa oxigenação porque, plantas com baixa tolerância a alagamento, como A. thaliana, devem gerar ATP suficiente, regenerar $\mathrm{NADP}^{+}$e $\mathrm{NAD}^{+}$, e evitar acúmulo de metabólitos tóxicos (BRAY et al, 2000).

Em plantas submetidas à hipoxia, foi observado aumento na produção de $\mathrm{H}_{2} \mathrm{O}_{2}$ nas condições SL e SLS na linhagem selvagem, e aumento na condição SLS na 
linhagem mutante comparando-a com a controle (figura 27A). KLOK et al (2002) descreveu um aumento na produção de ROS após estresse por alagamento. De acordo com BLOKHINA et al (2003), o início da hipoxia, e subseqüente reoxigenação, é manifestada por aumento na produção de ROS e peroxidação lipídica. AlBRECHT \& WiEDENROTH (1994) mostraram um aumento na captação de oxigênio após a re-aeração como resposta a alta demanda energética de reativação de metabolismo. Esse processo é acompanhado por rápido consumo de açúcares previamente acumulados e rápida elongação da raiz (ALBRECHT et al, 1993). O fenômeno de injúria pós-hipoxia é responsável pela geração de ROS e produtos oxidativos tóxicos como acetaldeído (CRAWFORD, 1992). $\mathrm{H}_{2} \mathrm{O}_{2}$ poderia ser produzido também como conseqüência do bloqueio da cadeia de transporte de elétrons mitocondrial (BAXTER-BURRELL et al, 2002). De acordo com VANTOAI \& Bolles (1991), condições que favorecem a formação de ROS, como baixa carga energética, altos níveis de equivalentes redutores, e cadeia de transporte de elétrons saturada, usualmente prevalecem nos tecidos das plantas quando o fornecimento de oxigênio é restrito.

Em células de fungos e mamíferos, a hipoxia estimula a produção do ânion superóxido no complexo mitocondrial III por aumentar a abundância do parcialmente reduzido ânion ubisemiquinona (CHANDEL \& SCHUMACKER, 2000; SEMENZA, 1999). Esse ânion reativo é rapidamente convertido a $\mathrm{H}_{2} \mathrm{O}_{2}$ por dismutação espontânea ou pela SOD mitocondrial (FUKAO et al, 2004). A menor quantidade de $\mathrm{H}_{2} \mathrm{O}_{2}$ na linhagem mutante crescida sob hipoxia é coerente com as maiores atividades de CAT e GPX observadas na linhagem mutante nas condições de hipoxia (SL e SLS) e mesmo de CAT na condição controle em relação à linhagem selvagem. CAT detoxificaria $\mathrm{H}_{2} \mathrm{O}_{2}$ diminuindo sua quantidade. 
VANTOAI \& BOLlES (1991) observaram alta atividade de SOD em soja e sugeriram que esta enzima aumentaria a detoxificação de superóxido sob condições de re-oxigenação. BIEMELT (1998) observou aumento na atividade de APX, seguido de um vagaroso declínio aos níveis iniciais. Acúmulo de peróxido de hidrogênio e indução da atividade de SOD sob condições hipóxicas tem sido mostradas em raízes e folhas de Hordeum vulgare (KALASHNIKOV et al, 1994) e em raízes de trigo (BIEMELT et al, 2000). Em plantas de arroz, a atividade de CAT aumentou em condições de reoxigenação (USHIMARU et al, 1999).

KASHIWABARA (2003) avaliou a responsividade de plantas das linhagens selvagem e mutante submetidas à hipoxia e observou maior sobrevivência da selvagem em relação à mutante. RiBEIRO et al. (2005), por meio da construção de uma série de cassetes compreendendo a região promotora thi1 fusionada ao gene reporter GUS, observou um aumento na expressão de thi1-GUS em raízes sumetidas à hipoxia. Esses dados são consistentes com os nossos resultados de análise de expressão de RNAm thi1, por RT-qPCR, de plantas submetidas à hipoxia (figura 25B). Foi observada maior expressão de RNAm thi1 na linhagem mutante em relação à selvagem na condição SL (sólido/líquido), além da linhagem mutante apresentar tendência à maior expressão de RNAm thi1 na condição SLS, apesar desta não ser significativa estatisticamente.

Para analisar a responsividade das linhagens selvagem e mutante à ausência de sacarose, foi quantificado, em ambas, $\mathrm{H}_{2} \mathrm{O}_{2}$ e atividades de CAT, SOD, APX e GPX. Foi observado aumento na quantidade de $\mathrm{H}_{2} \mathrm{O}_{2}$ em plantas crescidas na ausência de sacarose nas linhagens selvagem e mutante em relação a seus respectivos controles, mas não houve aumento de um em relação ao outro (figura 28A). De acordo com BROUQUISSE et al (1991), na ausência de sacarose a taxa de regeneração de ADP diminui significantemente. A mitocôndria, conseqüentemente, funciona em respiração 
'estado 4', onde a redução na transferência de elétrons através da citocromo c oxidase pode resultar em alta produção de ROS na mitocôndria (BRAIDOT et al, 1999). Além do mais, foi observado um aumento na atividade de SOD, APX e GPX em ambas as linhagens em relação aos seus respectivos controles, além de uma maior atividade de SOD (figura 28B) e GPX (figura 28E) na linhagem mutante em relação à selvagem, o que indica, novamente, uma maior fragilidade da linhagem mutante a ROS. CONTENTO et al. (2004) mostrou que na ausência de açúcares há mobilização lipídica, transferência de ácidos graxos, $\beta$-oxidação, o que poderia acarretar o aumento de acil-Coenzime A oxidase em nível de mRNA, de proteína, e de atividade, além de aumento na quantidade de mRNA catalase. Na ausência de sacarose, onde há excesso de $\mathrm{H}_{2} \mathrm{O}_{2}$, parece ocorrer a superexpressão de enzimas antioxidantes para reduzir ROS. Não foram observadas diferenças na expressão de thi1, por análise de RT-qPCR, de plantas crescidas em meio sem sacarose (figura 25A).

MedinA-SiLva et al (2006) observaram aumento da atividade de SOD em cepa de Saccharomyces cerevisiae mutante para o gene THI4 e crescida a $30^{\circ} \mathrm{C}$ (em relação à cepa selvagem), enquanto a atividade de SOD quase triplicou ao crescer esta mesma linhagem a $37^{\circ} \mathrm{C}$. Entretanto, não foram observadas mudanças na atividade de catalase. Esses dados mostram que o mutante, órtologo a thi1 em S. cerevisiae, também se apresenta mais suscetível a danos, mesmo na condição controle, corroborando nossos dados. Quando o mutante THI4 é submetido à uma condição estressante $\left(37^{\circ} \mathrm{C}\right.$, maior produção de petites respiratórios), há aumento na atividade de SOD (MEDINA-SILVA et al, 2006), o que também é consistente com nossos dados (aumento na atividade de SOD na condição CE, figura 26A). A diferença é que no presente trabalho foi observado aumento na atividade de catalase na linhagem mutante em relação à selvagem em todas as condições estudadas (figura 26B). 
É interessante notar que esses resultados são concordantes com os apresentados para taxa de germinação de sementes. Como falado anteriormente, um dos fatores responsáveis pela perda de viabilidade da semente é o acúmulo de radicais livres. Sementes como as de Arabidopsis, estocam a maioria de suas reservas energéticas e de carbono como lipídeos e, durante a germinação, ácidos graxos são convertidos em carboidratos. Esse processo começa com a hidrólise de triglicerídeos estocados, seguidos por $\beta$-oxidação de ácidos graxos em peroxissomos especializados chamados glioxissomos (MCCLUNG, 1997), com conseqüente produção de radicais livres. Os resultados de viabilidade de sementes (em que a linhagem mutante apresenta menor viabilidade, figura 22) juntamente com os das enzimas antioxidantes indicam maior estresse oxidativo desta linhagem em relação à selvagem.

No geral, foi observada maior atividade de enzimas antioxidantes na linhagem mutante em relação à selvagem. A linhagem mutante, que possui a proteína THI1 defectiva, acumularia precursores da síntese de tiazol. Entre esses precursores há o gliceraldeído 3-fosfato, que participa da fotossíntese e da glicólise, vias conhecidamente responsáveis pela produção de ROS. Na linhagem mutante, portanto, haveria maior produção de ROS, o que acarretaria na maior produção de antioxidantes, como podemos observar nesse trabalho.

Devem ser feitas algumas considerações sobre os ensaios de GPX realizados nesse trabalho. Esses ensaios foram baseados naqueles realizados em animais (FLOHÉ \& GÜNZLER, 1984). Apesar da grande maioria das metodologias de ensaio de atividade de GPX ser em modelo animal, encontramos na literatura, no início da padronização do ensaio de GPX em placa, ensaios dessa enzima em Aloe vera (SABEH et al., 1993) e em Boea hygroscopica (NAVARI-Izzo et al., 1997), os últimos utilizando ensaios baseados na metodologia de FloHÉ \& GüNZLER (1984). Havia, também, alguns trabalhos que 
mostravam cDNAs de plantas codificando proteínas similares à GPX animal, em organismos como Citrus sinensis e Nicotiana sylvestris (GABER et al., 2001), e inclusive em A. thaliana (Sugimoto \& Sakamoto, 1997; Rodriguez Milla et al., 2003). Partimos do princípio, então, de que haveria atividade de GPX em plantas.

A análise de proteínas GPX-like em plantas mostrou identidade dessas proteínas com GPX de mamíferos, incluindo uma cisteína conservada no sítio ativo. Contudo, nas GPX de animais observa-se nessa posição um resíduo de selenocisteína (URSINI et al., 1995), parecendo ser responsável pela interação com GSH, o que não foi confirmado em plantas.

São conhecidos, entretanto, trabalhos posteriores aos de FLOHÉ \& GÜNZLER (1984) testando diferentes substratos para a reação catalisada pela GPX. HERBETTE et al. (2002) mostraram que Lycopersicon esculentum (tomate) e Helianthus annuus (girassol) podem utilizar tanto GSH quanto tiorredoxinas como agentes redutores. IQBAL et al. (2006) mostraram que nenhuma das isoformas de GPX em A. thaliana apresentaram atividade utilizando GSH como agente redutor, mas sim utilizando tiorredoxina.

Nos trabalhos relativos à análise de melhores substratos para os ensaios de atividade de GPX (Herbette et al., 2002; IQBAL et al., 2006) foi utilizado para o cálculo de atividade o coeficiente de extinção molar (ع). Os cálculos de GPX, nessa tese, foram baseados estritamente nas recomendações de FLOHÉ \& GÜNZLER (1984), utilizando a fórmula apresentada em sua publicação (ver item 3.3.4.1.6). Apesar de não acharmos adequada a utilização do coeficiente de extinção molar nesse caso, foram feitos os cálculos também utilizando o " $\varepsilon$ " (dados não mostrados) a fim de poder comparar nossos dados com as atividades obtidas utilizando diferentes substratos (IQBAL et al., 2006). De acordo com ESHDAT et al. (1997), a substituição do resíduo de selenocisteína por cisteina, poderia resultar em menor atividade em três ordens de magnitude. Analisando os resultados aqui 
apresentados de atividade de GPX em plantas utilizando a metodologia animal, podemos observar diferenças de três ordens de grandeza, como sugerido por ESHDAT et al. (1997).

Portanto, os resultados de GPX apresentados nesta tese devem ser levados em consideração, mesmo porque foram observadas diferenças significativas para GPX comparando as linhagens selvagem e mutante (figuras 26D, 27E e 28E), mas deve-se ter a ressalva de que os experimentos de GPX deveriam ser repetidos testando outras metodologias.

Como discutido anteriormente, a menor quantidade de $\mathrm{H}_{2} \mathrm{O}_{2}$ observada na linhagem mutante deve-se à maior produção de enzimas antioxidantes por esta linhagem (como mostram os resultados anteriores). Os antioxidantes não-enzimáticos (figura 29), especialmente ascorbato, parecem contribuir para a diminuição da quantidade de $\mathrm{H}_{2} \mathrm{O}_{2}$. A glutationa alterna-se entre o estado reduzido (GSH) e o estado oxidado (GSSG). Mudanças nas concentrações de GSH / GSSG refletem alterações relevantes no ambiente redox intracelular. Normalmente, os níveis de GSH são de 10 a 100 vezes superiores ao de GSSG (FILOMENI et al., 2002). Quando os níveis de GSSG aumentam, acredita-se que as células se encontrem em estado de estresse oxidativo. MEDINA-SILVA et al (2006) observaram nos mutantes thi4, homólogo de thi1 em leveduras, menores níveis de glutationa reduzida quando comparado à cepa selvagem (W303), o que poderia indicar uma condição altamente oxidativa.

Seguindo com o processo de caracterização funcional do gene thi1, foi feita a análise proteômica de extratos protéicos das linhagens selvagem e mutante. Pode-se observar na figura 30, que o perfil protéico das amostras submetidas à análise proteômica mostrou-se bastante adequado, já que as proteínas permaneceram intactas após a extração. Pode-se observar a banda da proteína rubisco (subunidade maior), a de 
maior intensidade, de aproximadamente 55KDa (PARRY et al., 1987). Quando não é possível observar esta proteína ou ela não se apresenta em maior quantidade do que as outras, significa que as proteínas do extrato estão degradadas.

Como se pode observar na tabela 4 , a proteína referente ao spot a foi identificada como uma fosfoglicerato desidrogenase e a referente ao spot $b$ foi identificada como uma fosfopiruvato hidratase (enolase). Ambas apresentaram maior expressão na linhagem mutante do que na selvagem. As proteínas referentes aos spots $c$ e $d$ não foram identificadas, pois estavam presentes em concentrações muito baixas e a tripsina utilizada para digerir a proteína do spot apresentou-se em maior quantidade do que a própria proteína.

A fosfoglicerato desidrogenase (E.C. 1.1.1.95, PGDH) é uma enzima envolvida na biossíntese de serina. A biossíntese de serina em plantas pode ocorrer por duas vias: a via do glicolato (na mitocôndria), associada com a fotorrespiração, e a via do 3fosfoglicerato (via fosforilada, no cloroplasto). A via do 3-fosfoglicerato, envolve 3 enzimas catalisando 3 reações seqüenciais: PGDH, 3-fosfoserina aminotransferase (PSAT) e 3-fosfoserina fosfatase (PSP) (Ho \& SAITO, 2001). O PGDH é a primeira enzima da via de biossíntese da serina fosforilada, e catalisa a oxidação de 3fosfoglicerato (3-PGA) a 3-fosfohidroxopiruvato (3-PHP), utilizando $\mathrm{NAD}^{+}$como cofator. Esta reação pode ocorrer nos dois sentidos e o sentido de biossíntese de serina não é o mais favorecido (Ho et al., 1999). O 3-PGA é disponibilizado pela glicólise ou pelo ciclo de Calvin.

Tem se proposto que a via fosforilada é, provavelmente, de menor significância comparada com a via do glicolato durante o dia, quando a fotorrespiração ocorre, mas pode ser importante no escuro (IRELAND \& HILTZ, 1995). Além disso, esta via parece 
ser importante para o fornecimento de serina a tecidos não fotossintéticos (Ho \& SAITO, 2001).

Serina atua como precursor de glicina e cisteína. Serina é a principal fonte para metabolismo $\mathrm{C} 1$, enquanto a glicina está envolvida na síntese de purinas. Serina é precursor de fosfatidilcolina (fosfolipídeos), que está envolvida em respostas adaptativas a estresse abiótico em plantas. Elevado acúmulo de serina e glicina, parece estar envolvido em respostas bioquímicas de plantas a diversas formas de estresses ambientais, como baixas temperaturas, alta salinidade e condições anaeróbicas (WADITEE et al, 2007). Além disso, foi observado acúmulo de RNAm de enzimas envolvidas na via fosforilada de síntese de serina sob condições de estresse abiótico (Ho \& SAITO, 2001).

Cisteína serve como precursor da síntese de glutationa, que é considerada reguladora de expressão gênica, controladora de proliferação celular e, também, responsável pela diminuição de ROS (YOUSSEFIAN et al, 2001). Além disso, HÉROUART et al (1993), demonstrou que o promotor da $\mathrm{Cu} / \mathrm{Zn}$ SOD citossólica, pode ser induzido por cisteína ou por GSH. Ou seja, fosfoglicerato desidrogenase é responsável pela produção de serina, esta de cisteína, esta de GSH e os dois últimos ainda atuam induzindo o promotor da SOD. Esses resultados estão coerentes com a tendência à maior produção de GSH na linhagem mutante. Além disso, serina está envolvida na produção de purinas, produção de novos nucleotídeos para aqueles danificados na linhagem mutante.

A fosfopiruvato hidratase (E.C. 4.2.1.11), também conhecida como enolase, converte 2-fosfoglicerato a fosfoenolpiruvato na via glicolítica e também parece atuar na expressão gênica. Em animais, parte da enolase se liga ao promotor do gene c-myc e reprime sua expressão e, em plantas (Arabidopsis), a enolase pode se ligar ao promotor 
do "zinc finger" STZ/ZAT10, cuja expressão é induzida rapidamente e transientemente por baixas temperaturas (LEE et al, 2002). Mutantes para o gene LOS2, cuja proteína é a enolase, são sensíveis a baixas temperaturas e esta condição induz morte celular programada (LEE et al, 2002). Segundo LEE et al (2002), a morte celular programada pode ser causada por desbalanços metabólicos devido à interrupção da atividade de enolase. Uma conecção entre enolase humana e apoptose foi demonstrada por RAY (1995). A enolase humana, MBP-1, quando transfectada para fibroblastos, causa rápida morte celular. A morte celular causada por MBP-1 parece não ser devido a efeito tóxico direto (RAY, 1995). O papel crítico de c-myc é na manutenção da proliferação celular e prevenção de apoptose. RAY (1995) sugere que quando o MBP-1 liga-se ao c-myc há diminuição na transcrição do gene, ocorrendo bloqueio da proliferação celular e a indução de apoptose. Considerando que o mesmo acontece nas plantas e que há superexpressão de enolase na linhagem mutante, haveria mais apoptose nesta linhagem em relação à selvagem. Um dos resultados da morte celular programada (PCD) é a fragmentação do DNA. Os dados de quantificação de danos (figura 34), em que observamos mais lesões na linhagem mutante corroboram esta hipótese. Além disso, a superexpressão de $\mathrm{PGDH}$, que produz mais serina, mais glicina, sendo a última envolvida na síntese de purinas, é coerente com a necessidade de reposição do material genômico em células que não entraram em PCD, mas que estão submetidas às mesmas condições de estresse oxidativo.

Apesar da quantidade de ROS ser diminuída pelos antioxidantes na linhagem mutante foi testado se os radicais livres produzidos, principalmente pela cadeia de transporte de elétrons da fotossíntese, ocasionariam mais danos no DNA de cloroplasto na linhagem mutante. Uma das opções seria a realização do "comet assay”. Para tanto, seria necessário extrair mitocôndrias e cloroplastos e padronizar esse ensaio para o 
genoma de organelas já que, normalmente, utiliza-se o genoma nuclear. A quantificação de danos e reparo de DNA por PCR quantitativa (QPCR) é altamente sensível já que permite a amplificação quantitativa de fragmentos de DNA genômico entre 10 e 25 kb. Como resultado, pequenas quantidades de lesões (de 1 a $105 \mathrm{~kb}$ ) podem ser detectadas, permitindo o estudo de danos e reparo de lesões no DNA em níveis biologicamente relevantes. Por ser um ensaio baseado em PCR, permite a utilização de alguns nanogramas de DNA genômico total, diferentemente de outras metodologias, como Southern blot ou HPLC, que requerem de 10 a 50 ug de DNA celular total. Além disso, o uso de DNA genômico, que inclui genomas nuclear, mitocondrial e de cloroplasto, permite a comparação direta de danos e reparo de DNA utilizando-se a mesma amostra biológica (SANTOS et al, 2006).

Os resultados apresentados na figura 34 mostram que plantas da linhagem mutante crescidas em meio com $0,1 \%$ de peróxido de hidrogênio possuem mais danos no DNA de cloroplasto que a linhagem selvagem, sugerindo que o peróxido de hidrogênio adicionado ao meio de crescimento mais a produção de ROS endógena podem aumentar a susceptibilidade do DNA de cloroplastos da linhagem mutante a danos. Provavelmente, $0,05 \%$ de peróxido de hidrogênio no meio de cultura não seja tão prejudicial à estabilidade genômica das plantas, o que justificaria quantidades parecidas de lesões nas duas linhagens.

Segundo AJJAWI et al (2007), há dois mecanismos diferentes envolvidos na produção de TPP a partir de tiamina exógena. No primeiro, bem caracterizado em $E$. coli, as enzimas tiamina quinase e tiamina monofosfato quinase (TMQ), catalisam a fosforilação de tiamina exógena e TP, respectivamente. No segundo mecanismo, descrito para S. cerevisiae, a enzima tiamina pirofosfoquinase (TPK), juntamente com um cátion bivalente (usualmente $\mathrm{Mg}^{2+}$ ) e ATP, catalisam a formação de TPP por meio 
da pirofosforilação direta de tiamina livre. Nesse segundo caso, na síntese de tiamina de novo, há produção inicial de TP, que se transforma em tiamina livre e transforma-se, então, pela ação da TPK, em TPP. Segundo ESTRAMAREIX \& DAVID (1996), a reação mais comumente observada nos organismos que produzem tiamina é a pirofosforilação direta de tiamina. A TPK tem sido detectada em diversas espécies de plantas, como milho, soja e tabaco (MOLIN \& FITES, 1980). Na linhagem mutante (tz-201) de thi1, foi observada apenas tiamina livre e TPP (figura 35C), o que é coerente com o fato de que a linhagem mutante não produz tiamina e a captação de tiamina exógena acarretaria a produção de TPP, sem ocorrer a produção de TP.

BETTENDORFF et al (2007), descreveram a descoberta do primeiro ATP ligado à tiamina em E. coli. Eles também observaram esse fenômeno em fungos e em raízes de plantas superiores. Eles notaram que quando E. coli é crescida em meio rico (com glicose), há a presença das tiaminas normalmente observadas (TP, TPP e também tiamina trifosfato, TPPP). Quando as bactérias são crescidas na ausência de glicose, não há a presença de TPPP, e há o surgimento de um pico desconhecido no cromatograma, que por espectrometria de massa e NMR (ressonância magnética nuclear) descobriram ser um ATP ligado a tiamina e nomearam AThTP, considerando esse composto mais um sinalizador do que propriamente um cofator.

A princípio, não era esperado observar tiaminas na linhagem mutante, já que esta linhagem produz THI1 defectiva e, portanto, deve ser suplementada com tiamina para crescer adequadamente, considerando que estas plantas foram crescidas na ausência desta vitamina. De qualquer maneira, é necessário lembrar que as tiaminas observadas podem ser provenientes de reservas da semente da planta, já que as anteriores foram crescidas em meio com tiamina. Além disso, sendo a tiamina um composto essencial para a planta, esse novo composto observado (figura 35C, seta 
vermelha) pode ser um intermediário da síntese de tiazol que acumula devido a inatividade de THI1. JURGENSON et al (2006) e GoDOI et al (2006) identificaram, de modo independente, que tanto a proteína de leveduras, THI4, quanto de Arabidopsis, THI1, carregam em sua estrutura um ligante não descrito anteriormente. Esse ligante chamado ADT (JURGENSON et al., 2006) ou AHZ (GODOI et al., 2006) é composto pelo anel de tiazol ligado a um ADP. O composto desconhecido que observamos (figura 35C, seta vermelha) pode ser um esqueleto resultante de síntese incompleta do anel de tiazol. O simples acúmulo desta substância poderia ser o responsável pelos resultados observados na linhagem mutante. A interrupção da via pode acarretar na quebra da homeostase celular em um momento de grande produção energética quando as organelas e citoplasma devem estar em completa sincronia para garantir o fluxo de energia gerado pela fotossíntese.(NOCTOR et al., 2007; SALERNO \& CURATTI, 2003).

O ideal seria desvendar esse composto por espectrometria de massa, seguida de NMR. A espectrometria de massa auxiliaria também na própria quantificação das tiaminas. Uma das dificuldades para quantificar a tiamina livre é que se observa um pico sobressalente a ele (figura 35C) devido, provavelmente, a pigmentos fotossintéticos que fluorescem no mesmo comprimento de onda das tiaminas. Além disso, como esse pico é muito largo, ele se encavala com o pico da tiamina monofosfato prejudicando também sua quantificação. A espectrometria de massa resolveria esse problema já que seria possível identificar as tiaminas pelas respectivas massas.

A fim de minimizar erros, tentou-se estabelecer um padrão interno que forneceria um fator de correção para as amostras. Até o momento, não há um padrão interno bem estabelecido para as tiaminas. Foi testada a 4-methylumbelliferone que emite fluorescência em um comprimento de onda semelhante àquele emitido pelas tiaminas, mas esse composto não foi considerado adequado já que não interagiu com a 
coluna, sendo eluído juntamente com a tiamina livre. AJJAWI et al (2007), normalizaram os dados pela quantidade de proteína presente nas plantas estudadas. Um dos primeiros passos na extração de tiamina é precipitação de proteínas por TCA, seguindo-se o processo de extração com o sobrenadante. A quantificação de proteínas foi realizada sobre as proteínas precipitadas.

Pela figura 35C pode-se observar maior produção de tiamina livre com uma pequena produção de TPP. A quantidade maior de tiamina livre já era esperada, pois a recuperação da tiamina livre da cromatografia de afinidade realizada deve ser maior que dos outros tipos de tiamina, já que esta não possui grupos fosfato (carga negativa) e, portanto, sua interação com a coluna de amina (carga positiva) será menor do que a interação desta com as outras tiaminas. Quanto mais grupos fosfatos, maior a interação da tiamina com a coluna e, portanto, mais tardia é a sua eluição da coluna (sairá em frações posteriores), além da tendência de ser menor sua recuperação. Segundo GUBLER (1991), grande proporção de tiamina presente em plantas está na forma de tiamina livre, diferentemente de animais em que mais de $90 \%$ das tiaminas ocorre na forma fosforilada.

RIBEIRO et al (2005) verificou que o promotor do gene thi1 é expresso em diversos tecidos, como um gene constitutivo, fortemente expresso nas folhas com expressão comparável à do gene constitutivo 35S. Considerando que THI1 está envolvido em síntese de tiamina é interessante notar que o gene thi1 está sob controle de um promotor constitutivo e altamente ativo (RIBEIRO et al, 2005). Apesar de tiamina ser requerida em quantidades mínimas, mostrou-se que complexos enzima-coenzima, tais como piruvato desidrogenase de mitocôndria de plantas são instáveis durante a purificação, comparando-se com os mesmos complexos presentes em mamíferos (Douce \& Neuburguer, 1989). Se o complexo é instável, a síntese de tiamina deve ser 
contínua e depender de uma taxa significante de síntese (RIBEIRO et al., 2005). A extração de tiaminas deve ser bastante eficiente para extrair a TPP livre e aquelas associadas a enzimas, que é uma quantidade amostral significante (GUBLER, 1991). Talvez esse fato justifique a menor quantidade de TPP, sendo esta a forma ativa atuante como cofator.

Esse trabalho foi iniciado com a hipótese de que THI1 apresentava duas funções e pretendiamos desvender sua segunda função por meio da caracterização fisiológica e bioquímica de thi1. Segundo GodoI et al. (2006), comparações da estrutura tridimensional da proteína THI1 a outras em bancos de dados, sugeriram homologia à tiorredoxina redutase (TRR). Para testarmos a hipótese de THI1 funcionar como tiorredoxina redutase, foram feitos ensaios utilizando a proteína THI1 purificada e verificando se esta possui atividade de tiorredoxina (TRX) e TRR. Não foram observadas atividades de TRX nem de TRR (dados não mostrados).

Apesar do indício anterior de THI1 funcionando como TRR, havia outros que não fortaleciam esta hipótese. TRR, em plantas, possuem uma sequência conservada no sítio ativo, Cys-Ala-Thr(Val)-Cys-Asp, e TRXs possuem outra sequência conservada, Trp-Cys-Gly[Ala]-Pro-Cys (DAI et al., 1996), que não foram encontradas em THI1. Além disso, TRRs purificadas apresentam coloração amarelada devido à presença do grupo FAD, essencial à sua atividade enzimática. A proteína THI1 purificada não apresenta coloração amarelada, sendo esse mais um indício de que esta proteína não seja uma TRR.

FAOU \& TROPSCHUG (2004), sugerem que CyPBP37 e thi4 (ortólogos a thi1) agem como chaperonas para diferentes enzimas da síntese de tiazol, proteção ao DNA mitocondrial e/ou resposta a estresse. Dessa forma, ortólogos de thi1 poderiam ter uma 
função de chaperona propriamente dita ou então participar da manutenção da homeostase redox, à semelhança das proteínas do tipo NUDIX (GE et al., 2007). 


\section{Modelo}

\section{Representação esquemática do desbalanço metabólico causado por THI1 defectivo}

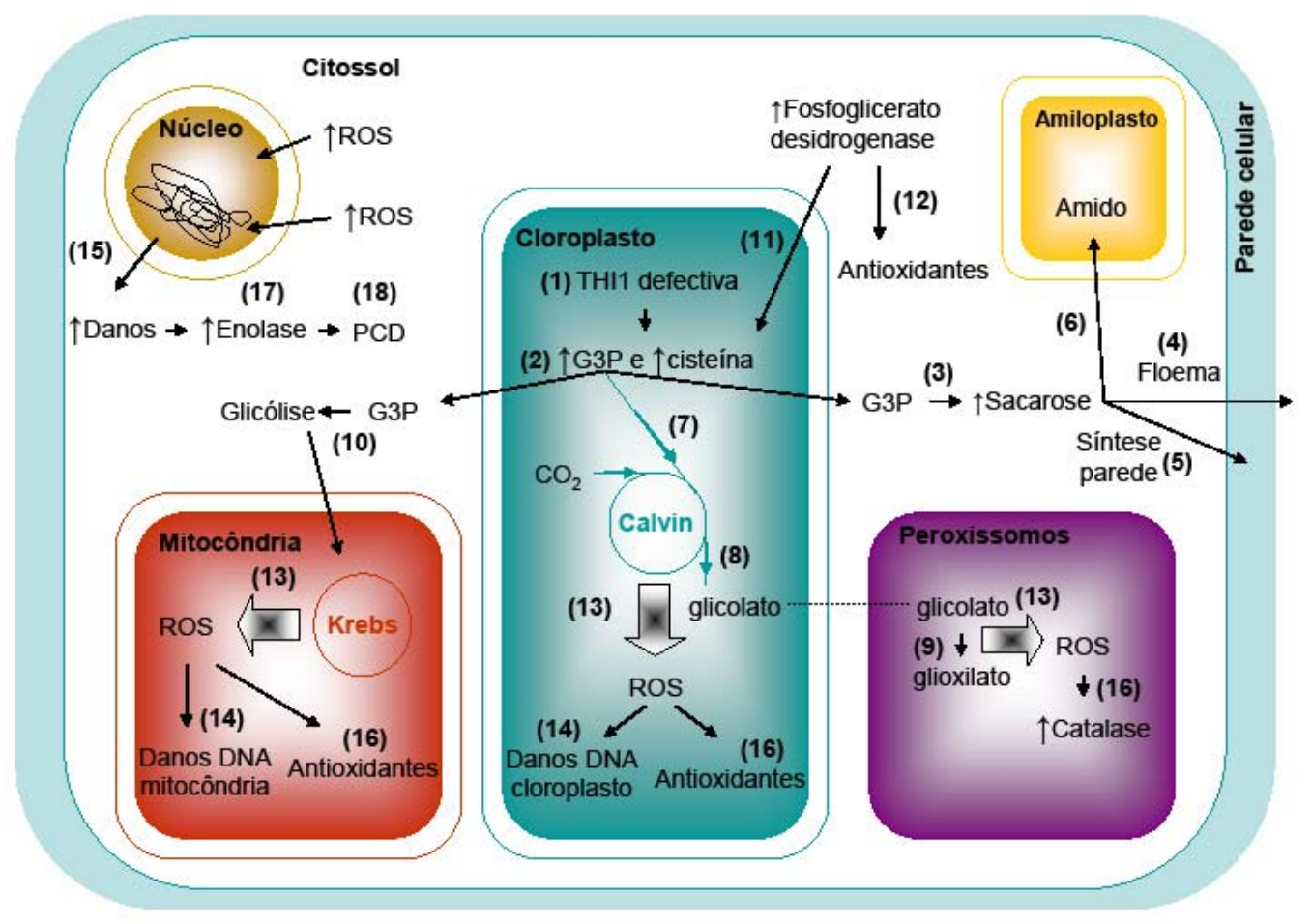

Figura 36: A proteína THI1 defectiva (1) provocaria o acúmulo de precursores do tiazol, entre eles cisteína e gliceraldeído 3-fosfato (G3P) (2). O gliceraldeído 3-fosfato (G3P) está envolvido na síntese de sacarose (3). O excesso de sacarose pode escoado para as raízes (4), para a síntese de parede celular (5) ou para a formação de grânulos de amido (6). Parte da G3P em excesso seria deslocada para o ciclo de Calvin a fim de regenerar a ribulose 1,5-bisfosfato (7). A rubisco pode funcionar como oxigenase produzindo glicolato (8), que é transferido para os peroxissomos e é convertido a glioxilato (9). A maior disponibilidade de G3P aumentaria, também, o fluxo de glicólise e, consequentemente, de respiração mitocondrial (10). A fosfoglicerato desidrogenase está envolvida na síntese de cisteína (11) que resulta, também, na produção de glutationa. A glutationa e a cisteína, por sua vez, seriam moduladores positivos, induzindo a região promotora do gene que codifica para SOD, acarretando, então, na maior produção de antioxidantes (12). A fotossíntese, a respiração e a fotorrespiração são processos envolvidos na produção de ROS (13), que poderiam danificar os DNAs organelares (14) ou o DNA nuclear (15). A maior quantidade de ROS nos tecidos acarreta na maior produção de antioxidantes (16), a fim de combatê-los. O acúmulo de enolase (17), envolvida no bloqueio da proliferação celular e, subsequente indução de morte programada celular (18) poderia explicar o atraso no desenvolvimento da linhagem mutante. 
Tendo em vista os resultados obtidos nesse trabalho, propõe-se que a proteína THI1 defectiva acarrete em desbalanço metabólico (figura 36), resultando em estresse oxidativo. Na ausência da proteína THI1 funcional, ocorreria o acúmulo de precursores imediatos do tiazol. Godor et al (2006) e JURGENSON et al (2006) sugerem como precursores a cisteína, a glicina (ou tirosina) e a AHZ (co-purificada à proteína THI1). Em bactérias, os precursores sugeridos são a cisteína e o gliceraldeído 3-fosfato. O gliceraldeído 3-fosfato (G3P) é um composto envolvido na síntese de sacarose. O acúmulo de sacarose na mutante poderia ser explicado pelo eventual aumento na disponibilidade de G3P. O excesso de sacarose, observado nos experimentos de quantificação dos açúcares solúveis, seria escoado para as raízes, o que aumentaria a massa fresca por contribuir com a retenção de água nos tecidos, já que se trata de uma substância osmoticamente ativa. Parte da G3P em excesso seria deslocada para o ciclo de Calvin a fim de regenerar a ribulose 1,5-bisfosfato, mimetizando uma condição de alta intensidade luminosa. Nesse caso, há diversos mecanismos que regulam o fluxo de energia nos fotossistemas, a fim de evitar que esses se danifiquem. Um dos mecanismos é a fotorrespiração que mantém o fluxo de elétrons nos fotossistemas diminuindo a oxidação parcial de aceptores no PSII, previnindo sua fotoinativação. Entretanto, o processo de fotorrespiração também está envolvido na síntese de ROS, em especial peróxido de hidrogênio nos peroxissomos. Havendo maior produção de ROS nos tecidos espera-se que a linhagem mutante apresente maiores quantidades de antioxidantes, como observado nesse trabalho. Esse fato também explicaria a redução das quantidades de $\mathrm{H}_{2} \mathrm{O}_{2}$ nos tecidos da linhagem mutante quando comparados aos da linhagem selvagem. Além disso, a própria sintese de sacarose gera um dreno forte o suficiente para a manutenção de um fluxo adequado de carbonos no ciclo de Calvin, ou seja, maior taxa fotossintética. A maior disponibilidade de G3P aumentaria o fluxo de 
glicólise e, consequentemente, de respiração mitocondrial, aumentando, do mesmo modo, a taxa de ROS. Segundo BELTRAMO et al. (2008), a presença de TPP escoa frutose-6-fosfato e gliceraldeído-3-fosfato da glicólise para a via pentose-fosfato, diminuindo a produção de ROS pela cadeia de transporte de elétrons (respiração). Além disso, segundo COUÉE et al. (2006) e MAY et al. (1998), vias metabólicas produtoras de NADPH, tal como a via da pentose-fosfato, contribuem para a captação de ROS, já que o NADPH é um importante cofator de vias que detoxificam ROS como os ciclos ascorbato-glutationa. A fosfoglicerato desidrogenase, que observamos em maior quantidade na mutante, está envolvida na síntese de cisteína que resulta, também, na produção de glutationa. A glutationa e a cisteína, por sua vez, seriam moduladores positivos, induzindo a região promotora do gene que codifica para SOD, acarretando, então, na maior produção de antioxidantes. Todos esses antioxidantes estariam envolvidos na detoxificação de ROS, presentes em excesso na linhagem mutante.

A diminuição da viabilidade de sementes ao longo do tempo de estocagem e a maior quantidade de danos no DNA quando as plantas são tratadas com $\mathrm{H}_{2} \mathrm{O}_{2}$ fortalecem a hipótese de desbalanço metabólico. No entanto, são necessários experimentos para verificar se há aumento na quantidade dos intermediários propostos, para sua plena sustentação. Na literatura há registro de que no momento da embebição da semente e retomada de atividade metabólica há grande produção de ROS pelas mitocôndrias ainda não totalmente preparadas para reagir ao metabolismo aeróbico.

O acúmulo de enolase, envolvida no bloqueio da proliferação celular e, subsequente indução de morte programada celular (PCD, do inglês programmed cell death) poderia explicar, em parte, o atraso no desenvolvimento da linhagem mutante. De mogo geral, os resultados obtidos indicam que a proteína THI1 não teria per se um papel específico em reparo, mas que, quando não funcional, provoca o acúmulo de 
compostos indutores de estresse oxidativo. Esses compostos seriam comuns a bactérias, leveduras e plantas, explicando desse modo o "efeito de tolerância a danos" observado em bactérias e leveduras e a impossibilidade de dissociar as duas funções por mutagênese sítio dirigida (GoDOI et al., 2006).

A hipótese inicial era a de que THI1 teria dupla função: síntese de tiamina e tolerância a danos no DNA. Os resultados apresentados nesse trabalho sugerem que THI1 escoa intermediários tóxicos, envolvidos no metabolismo oxidativo. Os animais, que não sintetizam tiamina e, portanto, não acumulam o intermediário predito, não apresentam deficiências reconhecíveis quando sua dieta é suplementada com tiamina. Já a linhagem de arabidopsis mutante, mesmo com o aporte de tiamina no meio, apresenta atraso no desenvolvimento, o que fortalece a hipótese aqui apresentada. 


\section{Conclusões}

Segundo os resultados obtidos nesse trabalho, podemos chegar às seguintes conclusões:

1) O gene thi1 apresenta um pico de expressão no período da tarde apresentando-se com um ritmo circadiano em potencial;

2) O acúmulo da proteína nos tecidos acompanha o perfil de expressão de RNAm thi1, o que sugere que o modo de regulação primária do gene é em nível transcricional;

5) A análise comparativa de proteína por gel bidimensional entre as linhagens selvagem e mutante permitiu a identificação de quatro proteínas em maior quantidade na mutante, sendo duas identificadas por seqüenciamento: enolase e fosfoglicerato desidrogenase.

6) A linhagem mutante acumula um composto, não identificado, que emite fluorescência no mesmo comprimento de onda que as tiaminas. Esse composto pode ser um precursor do tiazol.

7) Os resultados obtidos nesse trabalho sugerem que a proteína THI1 defectiva, ou sua ausência, pode acarretar em desbalanço metabólico ocasionando estresse oxidativo e alterações subsequentes. 


\section{Referências Bibliográficas}

AEBI, H. (1984) - Catalase in vitro. Methods in Enzymology 105, 121-130.

AjJawi, I.; Milla, M. A. R.; Cushman, J.; Shintani, D. K. (2007) - Thiamin pyrophosphokinase is required for thiamin cofactor activation in Arabidopsis. Plant Mol. Biol. 65, 151-162.

Alberts, B.; Johnson, A.; Lewis, J.; Raff, M.; Roberts, K.; WAlter, P. - Molecular Biology of the cell. 4. ${ }^{\mathrm{a}}$ ed. Garland Science, Taylor \& Francis Group, 2002. 1463 pp.

Albrecht, G.; Kammerer, S.; PrazniK, W.; Wiedenroth, E. M. (1993) - Fructan content of wheat seedlings (Triticum aestivum L.) under hypoxic and following re-aeration. New Phytol. 123, 471-476.

Albrecht, G. \& Wiedenroth, E. M. (1994) - Protection against activated oxygen following re-aeration of hypoxically pre-treated wheat roots. The response of the glutathione system. J. Exp. Bot. 45, 449-455

Alscher, R. G.; Erturk, N; Heath, L. S. (2002) - Role of superoxide dismutases (SODs) in controlling oxidative stress in plants. Journal of Experimental Botany 53 (372), 1331-1341.

APEL, K. \& HIRT, H. (2004) - Reactive oxygen species: metabolism, oxidative stress, and signal transduction. Annu. Rev. Plant Biol. 55, 373-399.

Ayala-Torres, S.; Chen, Y.; Svoboda, T.; Rosenblatt, J.; VAn Houten, B. (2000) Analysis of gene-specific DNA damage and repair using quantitative polymerase chain reaction. Methods 22(2), 135-47.

BAXTER-BURRELl, A et al. (2002) - RopGAP4-dependent Rop GTPase rheostat control of Arabidopsis oxygen deprivation tolerance. Science 296, 2026-2028. 
Beauchamp, C. \& Fridovich, I. (1971) - Superoxide Dismutase: Improved assays and an assay applicable to acrylamide gels. Analytical Biochemistry 44, 276-287.

Belanger, C.; Leustek, T.; Chu, B.; Kriz, A. (1995) Evidence for the thiamine pathway in higher plants plastids and its developmental regulation. Plant Molecular Biology 29, 809-821.

Beltramo, E.; Berrone, E.; TARallo, S.; Porta, M. (2008) - Effects of thiamine and benfotiamine on intracellular glucose metabolism and relevance in the prevention of diabetic complications. Acta Diabectol. No prelo.

BettendorfF, L.; WirtzFeld, B.; MaKarchikov, A.F.; Mazzucchelli, G.; Frédérich, M.; Gigliobianco, T.; Gangolf, M.; De Pauw, E.; Angenot, L.; WiNS, P. (2007) - Discovery of a natural thiamine adenine nucleotide. Nature Chemical Biology 3(4), 211-212.

Biemelt, S.; Keetman, U.; Albrecht, G. (1998) - Re-aeration following hypoxia or anoxia leads to activation of the antioxidative defense system in roots of wheat seedlings. Plant Physiol. 116, 651-658.

Biemelt, S.; KeETMAn, U.; Mock, H-P; Grimm, B. (2000) - Expression and activity of isoenzymes of superoxide dismutase in wheat roots in response to hypoxia and anoxia. Plant Cell and Environment. 23, 135-144.

Blokhina, O.; Virolainen, E.; FAgerstedt, K. V. (2003) - Antioxidants, oxidative damage and oxygen deprivation stress: a review. Annals of Botany 91, 179-194.

Bohr, V. A. \& DiAnOv, G. L. (1999) - Oxidative DNA damage processing in nuclear and mitochondrial DNA. Biochimie, 81, 155-160.

BRADFORD, M. M. (1976) - A rapid and sensitive method for the quantitation of microgram quantities of protein utilizing the principle of protein-dye binding. Analytical Biochemistry 72, 248-254 
Braidot, E.; Petrussa, E.; Vianello, A.; Macri, F. (1999) - Hydrogen peroxide generation by higher plant mitochondria oxidizing complex I or complex II substrates. FEBS Letters 451, 347-350

Bray, E. A.; Bailey- Serres J.; WeretilnyK, E. Responses to abiotic stresses. In: Buchanan, B. B.; Gruissem, W.; Jones, R. L.: Biochemistry and Molecular Biology of Plants. Waldorf: Am. Soc. Plant Physiol., 2000. pp. 1158-1203.

Britt, A. B. (1996) - DNA damage and repair in plants. Annu. Rev. Plant Physiol. Plant Mol. Biol. 47, 75-100.

Brouquisse, R.; James, F.; Raymond, P.; Pradet, A. (1991) - Study of glucose starvation in excised maize root tips. Plant Physiology 96, 619-626.

Buchanan, B. B.; Gruissem, W.; Jones, R. L. - Biochemistry and Molecular Biology of Plants. Waldorf: Am. Soc. Plant Physiol. 1367 pp., 2000.

Budde, R. J. A. \& Randall, D. D. (1990) - Pea leaf mitochondrial pyruvate dehydrogenase complex is inactivated in vivo in a light-dependent manner. Proc. Natl. Acad. Sci. USA 87 : 673-676.

CARdoso, V. J. M. Germinação. In: Kerbauy, G. B.: Fisiologia Vegetal. Rio de Janeiro, Guanabara Koogan, 2004. pp. 386-408.

Chabregas, S. M.; Luche, D. D.; Farias, L. P.; Ribeiro, A. F.; Van Sluys M. A.; Menck, C. F. M.; Silva-FiLho, M. C. (2001) - Dual targeting properties of the N-terminal signal sequence of Arabidopsis thaliana THI1 protein to mitochondria and chloroplasts. Plant Mol. Biol. 46, 639-650.

Chabregas, S. M.; Luche, D. D.; Van Sluys, MA; Menck, C. F. M.; Silva-Filho, M. C. (2003) - Differential usage of two in-frame translational start codons regulates subcellular localization of Arabidopsis thaliana THI1. Journal of Cellular Science 116, 285-291. 
ChANDEL, N.S.; SCHUMACKER, P.T. (2000) - Cellular oxygen sensing by mitochondria: old questions, new insight. J. Appl. Physiol. 88, 1880-1889.

Choi, G. H.; MareK, E. T.; Schardl, L. C.; Richey, M. G.; Chang, S.; Smith, D. A. (1990) - sti35, a stress responsive gene in Fusarium spp. J. Bacteriol., 172, $4522-4528$.

Contento, A.L.; Kim, S-J.; Bassham, D.C. (2004) - Transcriptome profiling of the response of Arabidopsis suspension culture cells to Suc starvation. Plant Physiology 135, 2330-2347.

Costa, R. M.; Morgante, P. G.; Berra, C.M.; Nakabashi, M; Bruneau, D.; Bouchez, D.; Sweder, K. S.; Van Sluys, MA; Menck, C. F. (2001) - The participation of AtXPB1, the $X P B / R A D 25$ homologue gene from Arabidopsis thaliana, in DNA repair and plant development. The Plant Journal 28, 385-395.

Couée, I.; Sulmon, C.; Gouesbet, G.; El Amrani A. (2006) - Involvement of soluble sugars in reactive oxygen species balance and responses to oxidative stress in plants. Journal of Experimental Botany 57 (3), 449-459.

CRAWfORD, R. M. M. (1992) - Oxygen availability as an ecological limit to plant distribution. Adv. Ecol. Res. 23, 93-185.

Croft, M. T.; Moulin, M.; WebB, M. E.; SMith, A. G. (2007) - Thiamine biosynthesis in algae is regulated by riboswitches. P.N.A.S. 104 (52), 20770-20775.

Dai, S.; SaArinen, M.; Ramaswamy, S.; Meyer, Y.; Jacquot, J. P.; Eklund, H. (1996) - Crystal structure of Arabidopsis thaliana NADPH dependent thioredoxin reductase at 2.5 A resolution. J. Mol. Biol. 264, 1044-1057.

Dalton, D. A. Antioxidant defenses of plant and fungi. In: Ahmad, S.: Oxidative Stress and Antioxidant Defenses in Biology. New York, Chapman \& Hall, 1995. pp. 298-355. 
Dat, J. F.; Capelli, N.; Folzer, H.; Bourgeade, P.; Badot, P. M. (2004) - Sensing and signalling during plant flooding. Plant Phys. Bioch. 42, 273-282.

Douce, R. \& Neuburguer, M. (1989) - The uniqueness of plant mitochondria. Annual Review of Plant Physiology 40, 371-414.

DREW MC. (1997) - Oxygen deficiency and root metabolism: Injury and acclimation under hypoxia and anoxia. Annu. Rev. Plant Physiol. Plant Mol. Biol. 48: 223250

Elder, R. H. ; Aquila, A. D.; Mezzina, M.; SARasin, A.; Osborne, D. J. (1987) - DNA ligase in repair and replication in the embryos of rye, Sacale cereale. Mutation Research 181, 61-71.

Eshdat, Y.; Holland, D.; FAltin, Z.; Ben Hayyim, G. (1997) - Plant glutathione peroxidases. Physiol. Plant. 100, 234-240.

EstramareiX, B.; DAVID, S. (1996) - Biosynthesis of thiamine. New Journal of Chemistry 20, 607-629.

FaOU, P. \& Tropschug, M. (2004) - Neurospora crassa CyPBP37: a cytosolic stress protein that is able to replace yeast thi4p function in the synthesis of vitamin B1. J. Mol. Biol. 344, 1147-1157.

FEENSTRA, W. J. (1964) - Isolation of nutritional mutants in Arabidopsis thaliana. Genetica, 35, 259-269.

Fett-Neto, A. G. Ritmos Circadianos nas Plantas. In: Kerbauy, G. B.: Fisiologia Vegetal. Rio de Janeiro, Guanabara Koogan, 2004. pp. 356-365.

Filomeni, G.; Rotilio, G.; Ciriolo, M. R. (2002) - Cell signalling and the glutathione redox system. Biochem. Pharmacol. 64, 1057-1064.

Flohé, L.; GÜNZLER, W. A. (1984) - Assays of glutathione peroxidase. Methods in Enzymology 105, 114-121. 
Fukao, T.; BAiley-Serres, J. (2004) - Plant responses to hypoxia - is survival a balancing act? Trends in plant science 9 (9), 449-456.

Gaber, A.; TAmoi, M.; Takeda, T.; NAkano, Y.; ShigeOKa, S. (2001) - NADPHdependent glutathione peroxidase-like proteins (Gpx-1, Gpx-2) reduce unsaturated fatty acid hydroperoxides in Synechocystis PCC 6803. FEBS Letters 499, 32-36.

Ge, X.; Li, G-J; WAng, S-B.; ZhU, H.; ZhU, T.; WAng, X.; XIA, Y. (2007) - AtNUDT7, a negative regulator of basal immunity in Arabidopsis, modulates two distinct defense response pathways and is involved in maintaining redox homeostasis. Plant Physiol. 145, 204-215.

GodoI, P.H.C.; Galhardo, R.S.; Luche, D.D.; Van Sluys, MA.; MencK, C.F.M.; OliVA, G. (2006) - Structure of the thiazole biosynthetic enzyme THI1 from Arabidopsis thaliana. JBC. 281 (41), 30957-66.

GuBler, C. J. Thiamin. In: Machlin, L. J.: Handbook of vitamins. New York, Marcel Dekker, 1991. pp. 233-281.

Halliwell, B \& Gutterridge, J. M. C. - Free Radicals in Biology and Medicine. 3.a ed. United States, Oxford Science Publications, 1999. 936 pp.

Herbette, S.; Lenne, C.; Leblanc, N.; Julien, JL.; Drevet, J. R.; Roeckel-Drevet, P. (2002) - Two GPX-like proteins from Lycopersicon esculentum and Helianthus annuus are antioxidant enzymes with phospholipid hydroperoxide glutathione peroxidase and thioredoxin peroxidase activities. Eur. J. Biochem. 269, 24142420.

HÉrouart, D.; VAn Montagu, M.; InZE, D. (1993) - Redox-activated expression of the cytosolic copper / zinc superoxide dismutase gene in Nicotiana. Proc. Natl. Acad. Sci. USA 90. 3108-3112. 
Ho, C. L. \& SAITO, K. (2001) - Molecular biology of the plastidic phosphorylated serine biosynthetic pathway in Arabidopsis thaliana. Amino Acids 20, 243-259.

Ho, C. L.; NoJI, M.; SAITO, M.; SAITO, K. (1999) - Regulation of serine biosynthesis in Arabidopsis. The Journal of Biological Chemistry 274 (1), 397-402.

Igbal, A.; Yabuta, Y.; Takeda, T.; Nakano, Y.; Shigeoka, S. (2006) Hydroperoxide reduction by thioredoxin-specific glutathione peroxidase isoenzymes of Arabidopsis thaliana. The FEBS Journal 273, 5589-5597.

Ireland, R. J. \& Hiltz, D. A. Glycine and serine synthesis in non-photosynthetic tissues. In: Wallsgrove, R. M.: Amino acids and their derivatives in higher plants. Cambridge, Cambridge University Press, 1995. pp. 127-134.

Jacob-Wilk, D.; Golschmidt, E.E.; Riov, J.; SAdKA, A.; Holland, D. (1997) Inductions of a Citrus gene highly homologous to plant and yeast thi genes involved in thiamine biosynthesis during natural and ethylene induced plant maturation. Plant Molecular Biology 35, 661-666.

Jefferson, R. A.; Kavanagh, T. A.; Bevan, M. W. (1987) - GUS fusions: $\beta$ glucuronidase as a sensitive and versatile gene fusion marker in higher plants. The EMBO Journal 6(13), 3901-3907.

JUlliard, J-H \& DOUCE, R. (1991) - Biosynthesis of the thiazole moiety of thiamine (vitamin B1) in higher plants chloroplasts. Proc. Natl. Acad. Sci. USA 88, 20422045.

Jurgenson, C. T.; Chatterjee, A.; Begley, T. P.; Ealick, S. E. (2006) - Structural insights into the function of the thiamin biosynthetic enzyme Thi4 from Saccharomyces cerevisiae. Biochemistry 45, 11061-11070.

KAlashniKov, JuE.; BALAKhnina, T. I.; ZAKRZHEVSKY, D. A. (1994) - Effect of soil hypoxia an activation of oxygen and the system of protection from oxidative 
destruction in roots and leaves of Hordeum vulgare. Russian Journal of Plant Physiology. 41, 583-588.

KASHiwabarA, P. M. (2003) - Interferência na expressão do gene thi1 de Arabidopsis thaliana: conseqüências biológicas. São Paulo, 2003. (Tese de mestrado, Instituto de Ciências Biomédicas, Universidade de São Paulo. 98 pp.).

Kawasaki, Y.; Nosaka, K.; KaneKo, Y; Nishimura, H; Iwashima, A. (1990) Regulation of thiamine biosynthesis in Saccharomyces cerevisaea. J. Bacteriol., 172, 6145-6147.

KimURA, S. \& SAKAGUCHI, K. (2006) - DNA repair in plants. Chem. Rev. 106, 753-766.

KloK, E.J.; Wilson, I.W.; Wilson, D.; ChapMan, S.C.; EwING, R.M.; SOMERVILle, S.C.; PeACock, W.J.; Dolferus, R.; DenNis, E.S. (2002) - Expression profile analysis of the low-oxygen response in Arabidopsis root cultures. Plant Cell 14, 2481-2494.

LAEMLI U. K. (1970) - Cleavage of structural proteins during the assembly of the head of bacteriophage T4. Nature. 227, 680-685.

Lee, H.; GuO, Y.; OhtA, M.; Xiong, L.; Stevenson, B.; Zhu, J. K. (2002) - LOS2, a genetic locus required for cold-responsive gene transcription encodes a bifunctional enolase. The EMBO Journal 21 (11), 2692-2702.

LiU, Z.; Hossain, G. S.; Islãs-OsunA, M. A.; Mitchell, D. L.; Mount, D. W. (2000) Repair of UV damage in plants by nucleotide excision repair: Arabidopsis UVH1 DNA repair gene is a homolog of Saccharomyces cerevisiae Rad1. The Plant Journal 21, 519-528.

LiVAK, K. J. \& SCHMitTGEN, T. D. (2001) - Analysis of relative gene expression data using real-time quantitative PCR and the $2^{-\Delta \Delta C T}$ method. Methods 25, 402-408. 
LOIVAMÄKI, M.; Louis, S.; CINEGe, G.; ZiMMER, I.; FisChBACH, R. J.; SCHNitZleR, J. P. (2007) - Circadian Rhythms of isoprene biosynthesis in grey poplar leaves. Plant Physiology 143, 540-551.

Luche, D. D. (2002) - Estudo das atividades bioquímicas da proteína THI1 de Arabidopsis thaliana. São Paulo, 2002. (Tese de doutorado, Instituto de Ciências Biomédicas, Universidade de São Paulo. 162 pp.).

Machado, C. R.; Costa de Oliveira, R.; Boiteux, S.; Praekelt, U. M.; Meacock, P. A.; MenCK, C. F. M. (1996) - Thi1, a thiamine biosynthetic gene in Arabidopsis thaliana, complements bacterial defects in DNA repair. Plant Mol. Biol. 31, $585-593$.

Machado, C. R.; Praekelt, U. M.; Oliveira, R. C.; Barbosa, A. C.; Byrne, K. L.; Meacock, P. A.; Menck, C. F. M. (1997) - Dual role for the yeast Thi4 gene in thiamine biosynthesis and DNA damage tolerance. J. Mol. Biol. 273, 114-121.

Mancinelli, R.; Ceccanti, M.; Guiducci, M. S.; Sasso, G. F.; Sebastiani, G.; Attilia, M. L.; Allen J. P. (2003) - Simultaneous liquid chromatographic assessment of thiamine, thiamine monophosphate and thiamine diphosphate in human erythrocytes: a study on alcoholics. Journal of Chromatography B. 789, $355-363$.

Manetti, A. G. O.; Rosetto, M.; Maundrell, K. G. (1994) - Nmt2 of fission yeast: a second thiamine-repressible gene co-ordinately regulated with nmt1. Yeast $\mathbf{1 0}$, $1075-1082$.

MAUNDRELL, K. (1990) - Nmt1 of fission yeast: a highly transcribed gene completely repressed by thiamine. J. Biol. Chem. 265, 19, 10857-10864. 
May, M.J.; VernouX, T.; Leaver, C.; Van Montagu, M.; Inzé, D. (1998) Glutathione homeostasis in plants: implications for environmental sensing and plant development. Journal of Experimental Botany 49, 649-667.

MCClung, C. R. (1997) - Regulation of catalases in Arabidopsis. Free Radical Biology \& Medicine. 23 (3), 489-496.

MCCord, J., M. \& Fridovich, I. (1969) - Superoxide Dismutase, an enzymic function for erythrocuprein (hemocuprein). The Journal of Biological Chemistry. 244 (22), 6049-6055.

Medina-Silva, R.; Barros, M.P.; Galhardo, R.S.; Netto, L.E.S.; ColePicolo, P.; MENCK, C.F.M. (2006) - Heat stress promotes mitochondrial instability and oxidative responses in yeast deficient in thiazole biosynthesis. Research in Microbiology. 157(3), 275-81.

MisRA, H. P. \& FRIDOVICH, I. (1971) - The generation of superoxide radical during the autoxidation of ferredoxin. J. Biol. Chem. 246, 6886-6890.

MitTLeR, R. (2002) - Oxidative stress, antioxidants and stress tolerance. Trends in Plant Science 7(9), 405-410.

Mittler, R.; Vanderauwera, S.; Gollery, M.; VAn Breusegem, F. (2004) Reactive oxygen gene network of plants. Trends in Plant Science. 9 (10), 490498.

Molin, W. T. \& Fites, R. C. (1980) - Isolation and characterization of thiamin pyrophosphotransferase from glycine max seedlings. Plant Physiol. 66, 308-312.

Moller, I. M.; JENSEN, P. E.; HANSSON, A. (2007) - Oxidative modifications to cellular components in plants. Annu. Rev. Plant Biol. 58, 459-481. 
Morgante, P. G. (2002) - Organização genômica e expressão dos genes AtXPB1 e AtXPB2 em Arabidopsis thaliana. São Paulo, 2002. (Tese de doutorado, Instituto de Biociências, Universidade de São Paulo. 150 pp.)

Murashige, T. And Skoog, F. (1962) - A revised medium for rapid growth and bioassays with tobacco tissue cultures. Physiol Plant 15(3): 473-497.

Murata, M.; Tsuchiya, T.; Roos, E. E. (1982) - Chromosome damage induced by artificial seed aging in barley: II. Types of chromosomal aberrations at first mitosis. Bot. Gaz 143, 111-116.

NAKANO, Y \& ASADA, K. (1981) - Hydrogen peroxide is scavenged by ascorbatespecific peroxidase in spinach chloroplasts. Plant Cell Physiol. 22, 867-880.

Navari-Izzo, F.; Meneguzzo, S.; Loggini, B.; Vazzana, C.; Sgherri, C. L. M. (1997)

- The role of the glutathione system during dehydration of Boea hygroscopica. Physiol. Plant. 99, 23-30.

Nelson, K. E.; Clayton, R. A.; Gill, S. R.; Gwinin, M. L.; Dodson, R. J.; Haft, D. H.; Hickey, E. K.; Peterson, J. D.; Nelson, W. C.; Ketchum, K. A.; Macdonald, L.; Utterback, T. R.; MaleK, J. A.; Linher, K. D.; Garrett, M. M.; Stewart, A. M.; Cotton, M. D.; Pratt, M. S.; Phillips, C. A.; Richardson, D.; HeidelberG, J.; Sutton, G. G.; Fleischmann, R. D.; Eisen, J. A.; White, O.; SAlzBerg S. L.; SMith, H. O.; Venter, J. C.; Fraser, C. M. (1999) - Evidence for lateral gene transfer between Archea and Bacteria from genome sequence of Thermotoga maritima. Nature, 399, 323-329.

Noctor, G.; De PAePe, R.; Foyer, C. H. (2007) - Mitochondrial redox biology and homeostasis in plants. Trends in Plant Science 12(3), 125-134.

Osborne, D. J. Senescence in seeds. In: Kenneth, V.: Senescence in plants. Boca Raton, CRC Press Inc, 1986. pp. 13-37. 
PAPINI-TERZI, F. S. (2000) - Investigação sobre o duplo papel do gene thi1 em Arabidopsis thaliana (Brassicaceae). São Paulo, 2000. (Tese de doutorado, Instituto de Biociências, Universidade de São Paulo. 134 pp.).

Papini-Terzi, F. S.; Galhardo, R. S.; Farias, L. P.; Menck, C. F. M.; Van Sluys, M. A. (2003) - Point mutation is responsible for Arabidopsis tz-201 mutant phenotype affecting thiamin biosynthesis. Plant Cell Physiol. 44(8), 856-860.

Parry, M. A. J; Schmidt, C. N. G.; Cornelius, M. J.; Millard, B. N.; Burton, S.; GutTeridge, S.; Dyer, T. A.; Keys, A. J. (1987) - Variations and properties of ribulose-1,5-bisphosphate carboxylase from various species related to differences in amino acid sequences. J. Exp. Bot. 38, 1260-1271.

Pinto, E.; Pedersén, M.; Snoeidis P.; VAn Nieuwerburgh, L.; ColePicolo, P. (2002) - Simultaneous detection of thiamine and its phosphate essers from microalgas by HPLC. Biochem. Biophys. Res. Com. 291, 2, 344-348.

Polle, A. (2001) - Dissecting the superoxide dismutase - ascorbate peroxidase glutathione pathway in chloroplasts by metabolic modeling. Computer simulations as a step towards flux analysis. Plant Physiol. 126, 445-462.

Potters, G.; Horemans, N.; Caubergs, R.J.; Asard, H. (2000) - Ascorbate and dehydroascorbate influence cell cycle progression in a tobacco cell suspension. Plant Physiol 124 (1), 17-20.

Praekelt, U. M.; Byrne, K. L.; Meacock, P. A. (1994) - Regulation of thi4 (mol 1), a thiamine-biosynthetic gene of Saccharomices cerevisiae. Yeast 10, 481-490.

Punchard, N. A. \& Kelly, F. J. - Introduction. In: Punchard, N. A. \& Kelly, F. J. Free Radicals, A practical approach. United States, Rickwood \& Hames, 1996. pp. 1-8. 
RaO, M. V.; Paliyath, G.; Ormrod, D. P. (1996) - Ultraviolet-B-and ozone-induced Biochemical changes in antioxidant enzymes of Arabidopsis thaliana. Plant Physiol. $110,125-136$.

RAY, R. B. (1995) - Induction of cell death in murine fibroblasts by a c-myc promoter binding protein. Cell Growth \& Differentiation 6, 1089-1096.

Ribeiro, A.; Praekelt, U.M.; AkKermans, A.D.L.; Meacock, P.A.; Van Kammen, A.; Bisseling, T.; Pawlowski, K. (1996) - Identification of agthi1, whose product is involved in biosynthesis of the thiamine precursor thiazole in actinorhizal nodules of Alnus glutinosa. The Plant Journal 10, 361-368.

Ribeiro, D. T.; Farias, L. P.; Almeida, J. D.; Kashiwabara, P. M.; Ribeiro, A. F. C.; Silva-Filho, M. C.; Menck, C. F. M.; VAn Sluys, MA. (2005) - Functional characterization of the thi1 promoter region from Arabidopsis thaliana. Journal of Experimental Botany, 56 (417), 1797-1804.

Rich, P. R. \& BONNER, W. D. (1978) - The sites of superoxide anion generation in higher plant mitochondria. Arch. Biochem. Biophys. 188, 206-213.

Rodrigues Milla, M. A.; Maurer, A.; Rodriguez Huete, A. Gustafson, J. P. (2003) - Glutathione peroxidase genes in Arabidopsis are ubiquitous and regulated by abiotic stresses through diverse signaling pathways. Plant J. 36 (5), 602-615.

Roessner, U.; Wagner, C.; KopkA, J.; Trethewey, R. N.; Willmitzer, L. (2000) Simultaneous analysis of metabolites in potato tuber by gas chromatography mass spectrometry. Plant J. 23, 131-142.

Roessner, U.; Luedemann, A.; Brust, D.; Fiehn, O.; Linke, T.; Willmitzer, L.; FERNIE, A.R. (2001) - Metabolic profiling allows comprehensive phenotyping of genetically or environmentally modified plant systems. The plant cell 13, 11-29. 
SABeH, F.; Wright, T.; Norton, S.J. (1993) - Purification and characterization of a glutathione peroxidase from Aloe vera plant. Enzyme protein 47(2), 92-98.

SALERNO, G. L. \& CURATTI, L. (2003) - Origin of sucrose metabolism in higher plants: when, how and why?. Trends in Plant Science 8(2), 63-69.

SAntos, J.H.; Meyer, J.N.; Mandavilli, B.S.; VAn Houten, B. (2006) - Quantitative PCR-based measurement of nuclear and mitochondrial DNA damage and repair in mammalian cells. Methods Mol. Biol. 314, 183-199.

SEmenZA, G.L. (1999) - Perspectives on oxygen sensing. Cell 98, 281-284.

Sturm, A. \& TANG, G. Q. (1999) - The sucrose-cleaving enzymes of plants are crucial for development, growth and carbon partitioning. Trends Plant Sci. 4(10), 401407.

SudArsan, N.; BARrick, J. E.; BrEAKER, R. R. (2003) - Metabolite-binding RNA domains are present in the genes of eukaryotes. RNA 9, 644-647.

Sugimoto, M. \& SAкамото, W. (1997) - Putative phospholipid hydroperoxide glutathione peroxidase gene from Arabidopsis thaliana induced by oxidative stress. Genes Genet. Syst. 72, 311-316.

Sun, W.; GAO, S.; WANG, L.; ChEn, Y.; Wu, S.; WANG, X. (2006) - Microwave-assisted protein preparation and enzymatic digestion in proteomics. Molecular and cellular proteomics, 5, 769-776.

ThORE S, LeIBUndgut M, BAN N. (2006) - Structure of the eucaryotic thiamine pyrophosphate riboswitch with its regulatory ligand. Science, 312, 1208-1211.

Trethewey, R. N.; Geigenberger, P.; Riedel, K.; Hajirezaei, M. R.; Sonnewald, U.; STITT, M.; RIESMEIER, J. W.; WiLlMitZeR, L. (1998) - Combined expression of glucokinase and invertase in potato tubers leads to a dramatic reduction in starch accumulation and a stimulation of glycolysis. Plant J. 15, 109-118. 
Ursini, F.; Maiorino, M.; Brigelius-Flohé, R.; Aumann, K. D.; Roveri, A.; SchomburG, D.; FlohÉ, L. (1995) - Diversity of glutathione peroxidases. Methods Enzymol. 252, 38-53.

Ushimaru, T.; KANematsu, S.; Shibasaka, M.; Tsuji H. (1999) - Effect of hypoxia on the antioxidative enzymes in aerobically grown rice (Oryza sativa) seedlings. Physiologia Plantarum. 107, 181-187.

VAn Gesselen, P.; Ledeganck, P.; Wynant, I.; CAubergs, R.J.; Asard, H. (1998) The cantharidin-induced oxidative burst in tobacco BY-2 cell suspension cultures. Protoplasma. 205, 83-92.

VAn Sluys, MA; AlCANTARA-Gomes, R; MencK, C. E. (1986) - Escherichia coli xthA mutant is not hypersensitive to ascorbic acid/copper treatment - an $\mathrm{H}_{2} \mathrm{O}_{2}$ generating reaction. Mutat. Res. 174(4), 265-269.

VanToai, T. T.; Bolles, C. S. (1991) - Postanoxic injury in soybean (Glycine max) seedlings. Plant Physiol. 97, 588-592.

Waditee, R.; Bhuiyan, N. H.; Hirata, E.; Hibino, T.; Tanaka, Y.; Shikata, M.; TAKABE, T. (2007) - Metabolic Engineering for betaine accumulation in microbes and plants. The Journal of Biological Chemistry. 282 (47), 3418534193.

WANG, W.; VignANI, R.; SCALI, M.; CRESTI, M. (2006) - A universal and rapid protocol for protein extraction from recalcitrant plant tissues for proteomic analysis. Electrophoresis, 27, 2782-2786.

Youssefian, S.; NAKAMURA, M.; ORUdGEV, E.; KondO, N. (2001) - Increased cysteine biosynthesis capacity of transgenic tobacco overexpressing an Oacetilserine(thiol) lyase modifies plant responses to oxidative stress. Plant Physiology 126, 1001-1011. 
ANEXO 


\title{
Biochemical and physiological characterization of Arabidopsis thaliana plants with differential expression of thil gene: instead dual role of thil gene its defective protein causes metabolic imbalance.
}

Marisa Moura Momoli ${ }^{1}$, Priscila Mayumi Kashiwabara ${ }^{1}$, Breno Lourenzzo Salgado Guimarães ${ }^{1}$, André Teixeira da Silva Ferreira ${ }^{2}$, Jonas Perales ${ }^{2}$, Bennett Van Houten ${ }^{3}$, Carlos Frederico Martins Menck ${ }^{4}$, Marie-Anne Van Sluys ${ }^{1 *}$

${ }^{1}$ Depto. de Botânica, Instituto de Biociências, Universidade de São Paulo, Rua do Matão, 277, 05508-900, São Paulo, SP, Brazil

${ }^{2}$ Laboratory of Toxinology, Department of Physiology and Pharmacodynamics, Oswaldo Cruz Institute, Oswaldo Cruz Foundation, Av. Brasil, 4365, Rio de Janeiro RJ 21040-900, Brazil

${ }^{3}$ Laboratory of Molecular Genetics, National Institute of Environmental Health Sciences, National Institute of Health, Research Triangle Park, NC 27709, United States

${ }^{4}$ Depto. de Microbiologia, Instituto de Ciências Biomédicas, Universidade de São Paulo, Av. Prof. Lineu Prestes, 1374, 05508-900, São Paulo, SP, Brazil

*Corresponding author. Fax: +55 113091 7724. E-mail: mavsluys@ib.usp.br

Keywords: thil, Arabidopsis thaliana, DNA damage, hypoxia, antioxidant enzymes, proteome

\begin{abstract}
The A. thaliana thil gene is involved in thiamine biosynthesis and was firstly described as having a potential role in genome stability. In this work, we report the functional characterization of thil gene using A. thaliana mutant line and lineages with differential expression of this gene. The mutant line showed lower germination rate and higher sensitivity to flooding stress comparatively with other lines. We investigated the hydrogen peroxide $\left(\mathrm{H}_{2} \mathrm{O}_{2}\right)$
\end{abstract}


production, and SOD and CAT activities in the WT and mutant lines submitted to hypoxia. The mutant line showed a lower $\mathrm{H}_{2} \mathrm{O}_{2}$ quantity under hypoxia and a higher CAT activity even in the control condition in relation to the WT. At the same time, we could observe an increase in mRNA thil expression in the mutant line under hypoxia and a higher chloroplast DNA damage in the same line caused by hydrogen peroxide. Proteomic analysis showed an overproduction of phosphoglycerate dehydrogenase (PGDH) and enolase in the mutant line comparing to the WT. PGDH is involved in antioxidants synthesis while enolase blocks cellular growth and takes to programmed cell death. Results obtained in this study indicate that defective THI1 bring about metabolic imbalance and that, not necessarily, thil gene is involved in dual role.

\section{Introduction}

Arabidopsis thaliana thil is a single nuclear gene and was originally isolated from a cDNA library due to its capacity to complement mutant Escherichia coli defective in DNA repair (Machado et al., 1996). Ortholog genes from other species are described (Choi et al., 1990; Manetti et al., 1994; Praekelt et al., 1994; Belanger et al., 1995; Ribeiro et al., 1996; Jacob-Wilk et al., 1997, Sohn et al., 2000). Most of these genes are involved in thiamine biosynthesis, more precisely, in thiazole ring pathway. Interestingly, A. thaliana thil gene restored thiamine prototrophy of a THI4 yeast knockout strain and complemented its sensibility to genotoxic agents (Machado et al., 1997). THI1 protein is targeted simultaneously to mitochondria and chloroplasts by a post-transcriptional mechanism. The targeting of THI1 to mitochondria explains its capacity to complement THI4 yeast mutants. The thil mRNA has two in frame AUG codons and the distribution of THI1 in A. thaliana is determined by a differential usage of the translational initiation codons (Chabregas et al., 2001, 2003).

It was showed that the thiamine auxotrophic Arabidopsis mutant line, tz-201 (Feenstra, 1964), possess a single point mutation in a conserved region of thil gene (Papini-Terzi et al., 2003). In the same work, it was demonstrated that the tz-201 cDNA could not complement yeast THI4 disrupted yeast strain, while the wild-type cDNA conferred full complementation. Moreover, it was showed a reduction of mRNA thil expression in dark conditions, a more pronounced expression in shoots than in roots, and a non-influence by the absence of thiamine, as reported for the yeast ortholog THI4 gene (Praekelt et al., 1994).

A functional analysis of the thil promoter region was performed through a series of 
cassette constructions comprising the promoter fused to GUS reporter gene, to determine the expression pattern and the responsiveness to various stress conditions (Ribeiro et al., 2005). The results described previously by Papini-Terzi et al. (2003) were confirmed, and it was also shown that the expression is affected by light, high salinity, sucrose starvation and hypoxia. Godoi et al (2006) and Jurgenson et al (2006) resolved THI1 and thi4 protein structures, respectively. Both showed that these proteins exist as an octamer with two monomers and there is a precursor of thiazole tightly bound to the purified protein. Besides they discovered that this protein binds NAD instead of FAD.

High oxygen concentrations have been toxic (Halliwell \& Gutterridge, 1999). This toxicity is related to the high possibility of reactive oxygen species production, as singlet oxygen $\left({ }^{1} \mathrm{O}_{2}\right)$, superoxide radical $\left(\mathrm{O}_{2}{ }^{\bullet}\right)$, hydrogen peroxide $\left(\mathrm{H}_{2} \mathrm{O}_{2}\right)$ and hydroxyl radical $\left({ }^{\bullet} \mathrm{OH}\right)$ (Dalton, 1995). The three last compounds are resulted of 1, 2 or 3 electron transferences from molecular oxygen, respectively. The main sources of ROS in plants are photosynthesis, respiration and photorespiration. (Mittler, 2002).

Plants produce ROS also as signaling molecules to control processes such as programmed cell death, abiotic stress responses, pathogen defense and systemic signaling (Mittler, 2002). Whereas under normal growth conditions, the production of ROS is low, stresses can disrupt the cellular homeostasis of cells enhancing ROS production (Polle, 2001). Some products of ROS attack can interfere to nucleic acids functions, conceiving mainly double strand break (Van Sluys et al, 1986) and alterations in base sequences causing mutations (Punchard \& Kelly, 1996), what could provoke abnormality of some functions or the organism death.

Since ROS are produced under stress and normal conditions, plants developed a defense system that involves the limitation in their production and their scavenger (Alscher et al, 2002). The importance of ROS can be realized by the number and diversity of antioxidants in cells (Punchard \& Kelly, 1996). Major ROS-scavenging mechanisms of plants include superoxide dismutase (SOD, E. C. 1.15.1.1.), ascorbate peroxidase (APX, E. C. 1.11.1.11.) and catalase (CAT, E. C. 1.11.1.6.). SOD turns $\mathrm{O}_{2}{ }^{-}$into $\mathrm{H}_{2} \mathrm{O}_{2}$, and APX and CAT detoxify $\mathrm{H}_{2} \mathrm{O}_{2}$. APX needs ascorbate as intermediate to $\mathrm{H}_{2} \mathrm{O}$ liberation, while CAT turns $\mathrm{H}_{2} \mathrm{O}_{2}$ into $\mathrm{H}_{2} \mathrm{O}$ and $\mathrm{O}_{2}$ straightly.

The present work reports the functional characterization of thil gene using A. thaliana wild-type (WT), mutant (tz-201), sense (thils a) and antisense (thilas a) lines to the thil gene. To these four lines, it has analyzed biological parameters as germination rate and tolerance to 
flooding. Next we worked specifically with WT and mutant lines. It has investigated the hydrogen peroxide $\left(\mathrm{H}_{2} \mathrm{O}_{2}\right)$ production, SOD and CAT activities in plants submitted to hypoxia, and chloroplast DNA damage in plants grown under normal conditions. Besides, it has analyzed the effect of continuous flooding stress on survival rates of wild-type, mutant and transgenic plants and also the thil mRNA expression in plants under hypoxia. Comparative proteomic analysis has been applied either. It was observed, in the mutant line, lower germination rate, higher antioxidant production, higher DNA damage amount in chloroplasts and lower survival rates in plants submitted to hypoxia. The comparative analysis of protein by bidimensional gel between wild-type and mutant line allowed the identification of four proteins in higher amount in the mutant line, two of them identified: enolase and phosphoglycerate dehydrogenase. Results indicate that defective THI1 bring about metabolic imbalance and that, not necessarily, thil gene is involved in dual role.

\section{Material and Methods}

\section{Plant material and culture conditions}

Landsberg erecta (Ler) ecotype (wild-type), mutant (tz-201) and transgenic (thils and thilas) lines of $A$. thaliana were employed. For in vitro cultivation, seeds were surface sterilized by 7 minutes immersion in commercial bleach $(2.5-3 \% \mathrm{NaClO})$ and $0.1 \%$ Tween 20 . Seeds were washed with sterile distilled water and sown onto solidified MS media half-strength macronutrients plus 20 g. $\mathrm{L}^{-1}$ of sucrose (MS 1/2 20) (growth under normal conditions). The seeds were maintained in a culture room for a $12 \mathrm{~h}$ daily period at $22 \pm 2^{\circ} \mathrm{C}$. For seed production, a mixture of sterile soil mixed with vermiculite $\mathrm{v} / \mathrm{v}$ 1:1 was used for growth as well, and the conditions were similar for those used in vitro. In this case a nutritive solution $\left(5 \mathrm{mM} \mathrm{Ca}\left(\mathrm{NO}_{3}\right)_{2}\right.$,

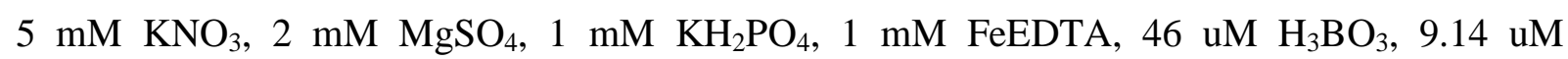
$\left.\mathrm{MnCl}_{2} .4 \mathrm{H}_{2} \mathrm{O}, 8.06 \mathrm{uM} \mathrm{ZnCl}, 0.37 \mathrm{uM} \mathrm{CuCl}_{2}, 0.1 \mathrm{uM} \mathrm{NaMoO}{ }_{4} \cdot 2 \mathrm{H}_{2} \mathrm{O}\right)$ was supplied once a week. All plants used in experiments were harvested 10am.

\section{Binary vector construction for antisense and sense expression of thi 1}

The vector pBlueScript (Stratagene) containing the A. thaliana thil cDNA was provided by Dr. C. F. M. Menck (Universidade de São Paulo, Brazil). The insert was obtained by EcoRI restriction and subcloned into pBC SK (Stratagene) EcoRI site in sense and antisense orientation. 
The inserts in both orientations and carrying the ClaI / BamHI sites were transferred to binary vector pGA643 (Gynheung et al., 1989) previously digested with ClaI and BglII. This binary vector contains the CaMV $35 \mathrm{~S}$ promoter and the neomycin phosphotransferase selection gene.

\section{Arabidopsis transformation and selection}

Wild-type plants from the Ler ecotype and Agrobacterium tumefaciens strain LBA4404 carrying the constructs described above were used for genetic transformation by the infiltration method (Clough \& Bent, 1998). Seeds were collected and germinated in vitro on selective media (MS 1/2 20 and $25 \mathrm{mg} \mathrm{L}^{-1}$ kanamicin). Resistant plants $\left(\mathrm{T}_{0}\right)$ were removed from plates and placed into soil until seed harvesting. Seeds $\left(T_{1}\right)$ were individually collected from each plant and submitted for a second screen for kanamicin resistance and segregation analysis. For further experiments, $\mathrm{T}_{2}$ and $\mathrm{T}_{3}$ seeds were used.

\section{$q R T-P C R$}

For the analysis of RNA levels by real-time PCR, we extracted total RNA from 50-100 mg plants using TRIzol ${ }^{\mathrm{TM}}$ reagent (Invitrogen) and they were treated with DNAse I (Ambion), as recommended by the manufacturer. Reverse transcription was performed using the kit "SuperScript III First Strand" (Invitrogen). We used specific primers for thil (5' GAT CGA TGG TGC ACC GAG AA 3' and 5' GCA AGT TGT CCC GCC TTT TG 3') and for UBQ14 (5' TCA CTG GAA AGA CCA TTA CTC TTG AA 3' and 5' AGC TGT TTT CCA GCG AAG ATG 3'). PCR was performed in the presence of the double stranded DNA specific dye SYBER Green (Applied Biosystems). Amplification was monitored in real time using the Applied Biosystems 7500 real-time PCR system. We used the following thermocycler profile: an initial denaturation for $10 \mathrm{~min}$ at $95^{\circ} \mathrm{C}$ followed by 40 cycles of $95^{\circ} \mathrm{C}$ denaturation for $15 \mathrm{~s}$ and $55^{\circ} \mathrm{C}$ primer extension for $1 \mathrm{~min}$. We performed qRT-PCR to compare thil expression among wildtype (Ler), mutant (tz-201) and transgenic lines of Arabidopsis grown under normal conditions, and also to compare thil expression in wild-type (Ler) and mutant (tz-201) lines submitted to hypoxia, condition described below.

\section{Total protein extraction and slot blot analysis}

Total protein was extracted from 30 days-old plants (2 g) from wild-type (Ler), mutant (tz-201) 
and transgenic lines (thils and thilas, $\mathrm{T}_{3}$ generation). It was used 2.5 volumes of $0,1 \mathrm{M}$ TRIS $\left(\mathrm{pH} \mathrm{7,6)}\right.$ and $0,1 \%$ ascorbic acid. It was centrifuged at $13500 \mathrm{~g}$ for $5 \mathrm{~min}$ at $4{ }^{\circ} \mathrm{C}$ and extracts from the soluble fractions were filtered through $0.45 \mu \mathrm{M}$ filters (Millipore). The protein content was determined according to Bradford (1976), with ovoalbumin as standard.

Samples of THI1 and AtXPB1 purified recombinant were applied in quantities of $0.01 \mu \mathrm{g}$, while extracts of wild-type (LER), mutant (tz-201) and transgenic (thils a and thilas a) lines were applied in quantities of $1 \mu \mathrm{g}$, in duplicate, on a nitrocellulose membrane, equilibrated in TRISGlycine 1X (25 mM TRIS; 250 mM Glycine pH 8.3; 0,1\% SDS) plus 10\% methanol for 15 min. Transfer was made through HYBRI-SLOT ${ }^{\mathrm{TM}}$ (Manifold, Life Technologies). The membrane was put on a block solution (TBS 1X (0.02 M TRIS; $0.14 \mathrm{M} \mathrm{NaCl} \mathrm{pH} 7.5) ; 0,05 \%$ Tween; $5 \%$ Skimmed Milk), at room temperature for $24 \mathrm{~h}$. Afterwards, the membrane was put in contact with the primary antibody, polyclonal anti-THI1 $(130 \mathrm{ug} / \mathrm{mL}$, dilution 1:500, Chabregas et al. 2001) for $2 \mathrm{~h}$, at $4^{\circ} \mathrm{C}$, washed 3 times with TBS $1 \mathrm{X} / 0,1 \%$ Tween 20 for $10 \mathrm{~min}$, incubated with secondary antibody (anti-mouse IgG peroxidase, Sigma), in dilution 1:2000 for 1 hour at $4^{\circ} \mathrm{C}$ and washed again.

Revelation was performed using "ECL Western Blotting detection reagent" (Amersham Pharmacia Biotech), according to manufacturer. Luminescence exposition occurred at room temperature for 5 minutes. Quantification of the resulting auto radiographs was determined by densitometry, using 1D Image Analysis Software (Kodak Digital Science).

\section{Germination rate}

To determine the germination rate, Arabidopsis seeds from wild-type (Ler), mutant (tz-201) and transgenic lines (thils and thilas, $\mathrm{T}_{3}$ generation) were sown onto MS $1 / 220$ after surface sterilization. Seeds stocked by 3, 6, 9 months or not stocked (0) were analyzed. After 7 days, the number of viable seeds was counted. The germination rate $(\%)$ was calculated considering the number of viable seeds $(\mathrm{G})$ by total seeds $(\mathrm{T})(\mathrm{G} / \mathrm{T})$.

\section{Survival rate to flooding}

Flooding condition was applied to in vitro germinated 5 days-old plantlets $\left(\mathrm{T}_{2}\right)$ to verify the survival rates of the wild-type (Ler), mutant (tz-201), sense (thils) and antisense (thilas) lines. They were transferred to MS $1 / 220$ liquid media with thiamine, where only the roots were 
submerged. Each 7 days, media was added to guarantee the plants were not under nutrients deprivation. The survival rates of the plants were analyzed in each 7 days, during a total of 28 days.

\section{$\mathrm{H}_{2} \mathrm{O}_{2}$ detection and antioxidant enzyme activities}

\section{Experimental conditions}

Hypoxia

To analyze the effects of hypoxia three batches of wild-type line and three batches of mutant line were cultivated in MS $1 / 220$ solid medium with thiamine and 12h photoperiod for 14 days. Two batches of each line were then transferred to MS 1/2 20 liquid medium, just keeping roots submerged, for $48 \mathrm{~h}$. Afterwards, one batch from the liquid medium was transferred to the solid medium (SFS, solid/flooding/solid) and other remained in the liquid medium (SF, solid/flooding) for more $48 \mathrm{~h}$. One batch remained in solid medium containing $20 \mathrm{~g} . \mathrm{L}^{-1}$ of sucrose (MS $1 / 220$ ) as control (C, control). Extracts of 18-day-old plants were used to verify SOD and CAT activities $\mathrm{H}_{2} \mathrm{O}_{2}$ detection

$\mathrm{H}_{2} \mathrm{O}_{2}$ detection was based on the method of Van Gestelen et al (1998). Wild-type (Ler) and mutant (tz-201) lines $\left(\mathrm{T}_{3}\right)$ were grown under hypoxia and control conditions, as described before. Eighteen day-old plants were harvested and their $\mathrm{H}_{2} \mathrm{O}_{2}$ content determined. By this methodology, $\mathrm{H}_{2} \mathrm{O}_{2}$ production is measured as the peroxidase-dependent oxidation of 3.5-dichloro-2hydroxybenzenesulfonic acid (DCHBS) to its quinone form, which specifically reacts with 4aminoantipyrine (AAP) to generate a molecular complex absorbing at $510 \mathrm{~nm}$ (Van Gestelen et $a l, 1998)$. Four to eight plants of each line were submerged in a solution containing $10 \mathrm{mM}$ DCHBS, $10 \mathrm{mM}$ AAP, up to $1 \mathrm{mg} / \mathrm{mL}$ of horseradish peroxidase (HRP) and MS $1 / 220$ liquid medium to complete the volume. After 2 hours, pools of $500 \mu \mathrm{L}$ were taken out, put on a polypropylene cuvett to be recorded by a spectrophotometer (Pharmacia) and next put back in the assay. After measurements the material was weighed. It was made a $\mathrm{H}_{2} \mathrm{O}_{2}$ curve with concentrations between $0.5 \mu \mathrm{M}$ and $40 \mu \mathrm{M}$.

\section{Antioxidants}

\section{Extraction of antioxidant enzymes}

Extraction was made essentially as described by Rao et al. (1996). Eighteen day-old plants from wild-type (Ler) and mutant (tz-201) lines $\left(\mathrm{T}_{3}\right)$ were homogenized with $100 \mathrm{mM}$ potassium 
phosphate (pH7.5) containing $2 \mathrm{mM}$ EDTA and $1 \%$ PVPP at $4{ }^{\circ} \mathrm{C}$. The homogenate was filtered through $0.45 \mu \mathrm{M}$ (Millipore) filter and centrifuged at $15.000 \mathrm{~g}$ for $20 \mathrm{~min}$. Protein content in the supernatant was concentrated by ammonium sulfate precipitation. Ammonium sulfate fractions between $45 \%$ and $90 \%$ were pooled and extensively dialyzed against $10 \mathrm{mM}$ TRIS-HCl (pH 7.5) containing $1 \mathrm{mM}$ EDTA with three changes of buffer each $3 \mathrm{~h}$ at $4^{\circ} \mathrm{C}$. Dialyzed and concentrated protein extracts were stored at $-80^{\circ} \mathrm{C}$ for further analysis. Protein content was determined according to the method of Bradford (1976) with ovoalbumin as standard.

Enzymes Assays

$S O D$

SOD activity was based on the indirect spectrophotometric method of McCord and Fridovich (1969) performed at $25^{\circ} \mathrm{C}$ for $8 \mathrm{~min}$ at $550 \mathrm{~nm}$. The assay was performed in a polypropylene plate with $200 \mu \mathrm{L}$ wells and recorder by a SpectraMax 190 (Molecular Device). The reaction mixture contained $0.05 \mathrm{M}$ potassium phosphate $(\mathrm{pH} 7.8), 9 \times 10^{-5} \mathrm{M}$ EDTA, $2 \times 10^{-8} \mathrm{M}$ ferricytochrome $c$, and $9 \times 10^{-5} \mathrm{M}$ xanthine. The assay was initiated by the addition of sufficient xanthine oxidase to produce a basal rate of ferricytochrome $c$ reduction corresponding to an increase in $\mathrm{A}_{550}$ of 0.025 absorbance units per min (V1). After verification of V1, extracts were added and the resulting reaction velocity (V2) calculated. One unit of superoxide dismutase was defined as the amount of enzyme which inhibited the rate of ferricytochrome $c$ reduction by $50 \%$ $(\mathrm{V} 1 / \mathrm{V} 2=2)$.

CAT

CAT activity was based on the direct spectrophotometric method of Aebi (1984), determined by the follow of the consumption of $\mathrm{H}_{2} \mathrm{O}_{2}$ at $20^{\circ} \mathrm{C}$ for $8 \mathrm{~min}$ at $240 \mathrm{~nm}$. The assay was performed in a quartz plate with wells of $200 \mu \mathrm{L}$ in a spectrophotometer SpectraMax 190 (Molecular Device). The difference in absorbance $\left(\Delta \mathrm{A}_{240}\right)$ per unit time is a measure of the catalase activity. The reaction mixture contained $50 \mathrm{mM}$ potassium phosphate $(\mathrm{pH}$ 7.8) and plant extracts and was initiated by adding $9.1 \mathrm{mM} \mathrm{H} \mathrm{H}_{2}$. It was made a $\mathrm{H}_{2} \mathrm{O}_{2}$ curve with concentrations between 0.5 $\mathrm{mM}$ and $9.1 \mathrm{mM}$.

\section{Quantitative PCR (QPCR)}

To compare DNA damage between wild-type (Ler) and mutant (tz-201) lines $\left(T_{3}\right)$, these were grown in MS $1 / 220$ solid medium for 18 days. Five hours before harvesting them, they were 
transferred to $\mathrm{MS} 1 / 220$ liquid medium where $\mathrm{H}_{2} \mathrm{O}_{2}$ were added at $0.1 \%$ and $0.05 \%$. QPCR assays were performed as described by Santos et al. (2002). Genomic DNA was isolated with the Dneasy Plant Mini (Qiagen) as described by the manufacturer. The concentration of total cellular DNA was determined by PicoGreen dsDNA Quantification kit (Molecular Probes) using the FL600 Microplate Fluorescence Reader form Bio-Tek®. QPCRs were performed with the GeneAmp XL PCR kit (Perkin-Elmer) as described by Santos et al (2002). The primer nucleotide sequences were as follows: for the 8.2-kb of chDNA, 5' CGG GCG GAT TCC TCC TTT TG 3' and 5' TTC ATT TGG GAC CCC GCA GA 3'; and for the $115 \mathrm{pb}$ of the chDNA, 5' TAA TTG GCG CGC TTG AGG AA 3' and 5' CGG AAA AGC CAA GGG GTC AA 3'. To amplify the largest fragment we used the following PCR profile: a hot start at $75^{\circ} \mathrm{C}$, an initial denaturation for $1 \mathrm{~min}$ at $94^{\circ} \mathrm{C}$ followed by 29 cycles of $94^{\circ} \mathrm{C}$ denaturation for $15 \mathrm{~s}, 54.9^{\circ} \mathrm{C}$ primer annealing for $45 \mathrm{~s}$ and $72^{\circ} \mathrm{C}$ primer extension for $10 \mathrm{~min}$. A final extension at $72^{\circ} \mathrm{C}$ was performed for $10 \mathrm{~min}$ at the completion of the profile. To amplify the smallest fragment we used the following PCR profile: a hot start at $75^{\circ} \mathrm{C}$, an initial denaturation for $1 \mathrm{~min}$ at $94^{\circ} \mathrm{C}$ followed by 27 cycles of $94^{\circ} \mathrm{C}$ denaturation for $1 \mathrm{~min}, 65^{\circ} \mathrm{C}$ primer annealing for $45 \mathrm{~s}$ and $72^{\circ} \mathrm{C}$ primer extension for $45 \mathrm{~s}$. A final extension at $72^{\circ} \mathrm{C}$ was performed for $5 \mathrm{~min}$. To ensure quantitative conditions, a control reaction with a half of the template DNA amount used was included with each amplification. DNA lesion frequencies were calculated as described (Santos et al, 2002). Amplification of small chDNA fragments is used to normalize the lesion frequency (obtained with amplification of the large fragment) to the chDNA copy number.

\section{Proteomic}

To compare protein expression between wild-type (Ler) and mutant (tz-201) lines $\left(\mathrm{T}_{3}\right)$, these were grown in MS $1 / 220$ solid medium for 18 days. Protein extraction was based on the protocol described by Wang et al. (2006) using $500 \mathrm{mg}$ of whole plants. It was used different biological quadruplicates. Protein concentrations were determined according to Bradford (1976), by using BSA as the standard protein.

\section{$2 D$ electrophoresis}

In the $2 \mathrm{D}$ electrophoresis, the first dimension or isoelectric focusing (IEF) was performed using strips of $18 \mathrm{~cm}$ and $\mathrm{pH} 4-7$ (GE - Amersham Biosciences) rehydrated for 14-20 h in $500 \mu \mathrm{L}$ rehydration buffer ( $8 \mathrm{M}$ urea, $2 \%$ CHAPS, $0.002 \%$ bromophenol blue, $2 \%$ IPG-buffer, $0.2 \%$ DTT). 
The protein sample (800 ug) was applied in the cup loading. IEF was carried out on the Multhiphor II (Amersham Biosciences) at $20^{\circ} \mathrm{C}: 1 \mathrm{~min}$ at $500 \mathrm{~V}, 30 \mathrm{~min}$ at $1500 \mathrm{~V}$ and $9 \mathrm{~h}$ at $3000 \mathrm{~V}$. Prior to second dimension analysis, the individual strips were equilibrated for $15 \mathrm{~min}$ in $10 \mathrm{~mL}$ equilibratium solution (6M urea, $30 \%$ glycerol, $2 \%$ SDS, $0.002 \%$ bromophenol blue, $50 \mathrm{mM}$ Tris $\mathrm{pH} 8.8$ ) containing $100 \mathrm{mg}$ DTT. The separation in the second dimension was performed on the PROTEAN II Ready Gel System (BioRad) with lab cast $1.5 \mathrm{~mm}$ in SDS-PAGE on $12 \%$ polyacrylamide gels. The electrophoresis conditions were $15 \mathrm{~min}$ under $15 \mathrm{~mA} / \mathrm{gel}$, and 7 h under $30 \mathrm{~mA} /$ gel.

\section{Protein visualization and image analysis}

Gels were fixed three times with $2 \%$ phosphoric acid and $30 \%$ ethanol for 30 min, then rinsed three times in $2 \%$ phosphoric acid for $20 \mathrm{~min}$, and incubated in $18 \%$ ethanol, $15 \%$ ammonium sulphate and $2 \%$ phosphoric acid for $30 \mathrm{~min}$. Gels were stained with $0.02 \%$ colloidal Coomassie Brilliant Blue G-250 for 72 h (Neuhoff et al., 1988). Finally, the gels were stored in a $1 \%$ acetic acid solution before digitalization. Stained gels were scanned and calibrated with labscan 5 software (Amersham Biosciences). Image analysis was performed with ImageMaster 2-D platinum (Amersham Biosciences). Spot detection and matching by ImageMaster were checked and edited manually when necessary. Spots that presented difference of at least $1.4 \mathrm{x}$ comparing WT and mutant lines were submitted to statistical analysis. These considered significantly different one each other were excised from the gel, submitted to digestion and then analyzed by MALDI-TOF-TOF.

\section{Protein identification}

Protein spots were manually excised from 2D gels that had been stained with colloidal Coomassie blue. Excised spots were transferred to centrifuge tubes of $0.6 \mathrm{~mL}$ and digested with $20 \mathrm{ng} / \mu \mathrm{L}$ trypsin. The proteolysis was carried out in two steps. The first digestion was performed according to protocol of digestion in microwaves (Sun et al. 2006). The second digestion was carried out after a new addition of $20 \mathrm{ng} / \mu \mathrm{L}$ trypsin, maintained at $37^{\circ} \mathrm{C}$ overnight. The digested peptide fragments were analyzed over the mass range of 800-3500 Da in a Maldi-TOF-TOF (4700 Proteomics Analyser, Applied Biosystems) Version 3.0 software, in the MS or in the MS/MS way. From the 5 more intense peaks it was possible to generate data for protein identification by Peptide Mass Fingerprinting (PMF) and/or by MS/MS Íon Score using the 
algorithm MASCOT4. The identifications were confirmed using the SCAFFOLD and/or PEAKS softwares.

\section{Statistical analysis}

Proteomic data were analyzed for significance by one-way analysis of variance (ANOVA one-way). Antioxidant enzymes, $\mathrm{H}_{2} \mathrm{O}_{2}$ production and qRT-PCR data were analyzed for significance by two-way analysis of variance (ANOVA two-way). Afterwards were made a posthoc multiple comparison Tukey test, considering to be significant $\alpha \leq 0.05$, both using the Statistica 6.0 program.

\section{Results}

Thil mRNA expression and THI1 protein production

Arabidopsis plants were transformed with the full-length thil cDNA in sense and antisense orientations, under the control of the cauliflower mosaic virus (CaMV) 35S promoter to cause thil mRNA overexpression and reduction in planta. This strategy was chosen because there are no null mutants described for this gene, only the tz-201 mutant line which presents a single point-mutation in a conserved region of the THI1 protein.

To investigate the expression pattern of thil mRNA in antisense and sense transgenic plants, total RNA was extracted from 18-days-old plants, transformed in cDNA and submitted to qRT-PCR analysis. There was no significant difference in expression between wild-type and tz201 mutant plants (figure 1A). On the other hand, in antisense transgenic lines there was a reduction of the thil transcript of about 50\% comparatively with wild-type and tz-201 line. In sense transgenic plants, it was observed $1000 \%$ greater levels of this transcript.

Purified recombinant THI1 and At-XPB 1 proteins were used as positive and negative controls, respectively. Using the primary anti-THI1 antibody we detected the THI1 protein in both positive control and plant extracts, while At-XPB 1 recombinant protein was not detected, as expected. Comparing the intensity of the bands related to positive control and plant extracts, it was shown that approximately $0.9 \%, 0.5 \%, 0.6 \%$ and $1 \%$ of proteins present in extracts from wild-type, mutant, sense and antisense, respectively, are THI1 protein (figure 1B). 


\section{FIGURE 1}

Figure 1: Relative expression of mRNA thil and THI1 production in A. thaliana WT (Ler), mutant (tz-201) and $\mathrm{T}_{3}$ plants of antisense and sense lines, under normal culture conditions. (A) Total RNA was extracted from 18-days-old plants, transformed in cDNA and submitted to qRTPCR analysis. Data are shown as relative expression, normalized with the constitutive UBQ14. (B) Quantitative analysis of THI1 protein. It was used the recombinant THI1 protein as a positive control and the recombinant At-XPB 1 as a negative control. 1 ug of each extract and $0.01 \mathrm{ug}$ of the purified samples were applied. The relative values were calculated by densitometry using $1 \mathrm{D}$ Image Analysis Software (Kodak Digital Science). Errors bars represent the standard deviation between duplicate.

\section{Germination rate}

Germination rate experiments were performed using wild-type, mutant and transgenic seeds stocked for 3, 6 and 9 months, or not stocked (0). Seeds sowed exactly onto after harvesting (0) showed almost $100 \%$ of germination rate. There was a considerable germination reduction of the seeds stocked for 6 months, mainly for the mutant line and, after 9 months, we observed a decrease in germination of all lines. The mutant line showed the lower germination rate $(21 \%)$ compared with wild-type (48\%), antisense (76\%) and sense (70\%) lines (figure 2).

\section{FIGURE 2}

Figure 2: Germination rate of wild-type (Ler), mutant (tz-201), sense (thils a) and antisense (thilas a) A. thaliana lines stocked for 3, 6 and 9 months or not stocked (0).

\section{Flooding stress}

In order to evaluate the responsiveness of sense and antisense transgenic plants to flooding stress, comparatively to wild-type and mutant lines, we submerged roots in liquid medium during 28 days.

Results showed there is a significant difference in survival rates between wild-type and mutant lines. On the other hand, sense transgenic plants have a tendency to be more tolerant to flooding 
stress than wild-type plants in the first 14 days, and antisense lines present an intermediate behavior between mutant and wild-type plants (figure 3).

\section{FIGURE 3}

Figure 3: Effect of continuous flooding stress on survival rates of wild-type, mutant and sense and antisense transgenic plants during 28 days. 5 days-old plantlets were transferred to liquid media, with the roots submerged (hypoxic condition). (A) Survival rates of antisense transgenic plants, compared with WT and mutant. (B) Survival rates of sense transgenic plants, compared with Ler and tz-201. Error bars represent the standard deviation between three independent experiments.

mRNA thil expression, $\mathrm{H}_{2} \mathrm{O}_{2}$ production and antioxidants activity under hypoxia

To evaluate the production of ROS in the wild-type and mutant lines, $\mathrm{H}_{2} \mathrm{O}_{2}$ was quantified in plants growth under control and hypoxia condition. There was an increase in $\mathrm{H}_{2} \mathrm{O}_{2}$ in the wild-type at SL and SLS conditions, and an increase in the mutant line at SLS condition (figure 4B). In general, the mutant line showed a lower $\mathrm{H}_{2} \mathrm{O}_{2}$ quantity than wild-type under hypoxia (figure 4B). No differences were observed in SOD activities under any experimental conditions (figure 4C). Nevertheless, the activity of CAT was increased in the mutant line in relation to the wild-type (figure 4D). As regards to mRNA thil expression, the mutant line showed more mRNA thil than the WT under SL condition (figure 4A).

\section{FIGURE 4}

Figure 4: mRNA thil expression, $\mathrm{H}_{2} \mathrm{O}_{2}$ production and antioxidants activity in A. thaliana WT (Ler) and mutant (tz-201) lines grown under normal conditions or hypoxia. (A) Relative expression of mRNA thil. Total RNA was extracted from 18-days-old plants, transformed in cDNA and submitted to qRT-PCR analysis. Data are shown as relative expression, normalized with the constitutive UBQ14. To quantify $\mathrm{H}_{2} \mathrm{O}_{2}$ and measure antioxidant activities A. thaliana

WT and mutant lines were grown in solid medium containing 20 g. $\mathrm{L}^{-1}$ of sucrose for 18 days $(\mathrm{C}$, control); or plants were grown in solid medium for 14 days and then transferred to liquid 
medium for 4 days (SL, solid/liquid); or plants were grown in solid medium for 14 days, transferred to liquid medium for 2 days and then transferred to solid medium for 2 days (SLS, solid/liquid/solid). (B) $\mathrm{H}_{2} \mathrm{O}_{2}$ was quantified using plants in vivo. (C) SOD activity. (D) CAT activity. Errors bars represent the standard deviation between duplicate. Significant differences $(\mathrm{P} \leq 0.05)$ are indicated $(*)$

\section{Chloroplast DNA damage quantification}

As THI1 is directed to chloroplast, we quantified damage in its DNA. We had to develop the best conditions to the QPCR assay: choose primers, the best temperature and the best number of cycles. QPCR assay was used to detect $\mathrm{H}_{2} \mathrm{O}_{2}$ induced DNA damage in an 8.2-kb fragment from chDNA which was normalized with the amplification of a small chDNA fragment $(115 \mathrm{pb})$. The best conditions were $54.9^{\circ} \mathrm{C}$ and 29 cycles. The standardization to the small fragment was similar to the larger. The best conditions were $65^{\circ} \mathrm{C}$ and 27 cycles (more details in Material \& Methods). In both, we find just one band after resolving PCR products in a polyacrilamide gel.

Damage to chDNA was higher in the mutant line submitted to $\mathrm{H}_{2} \mathrm{O}_{2} 0.1 \%$ (figure 5). It was not observed significative difference between the studied lines submitted to $\mathrm{H}_{2} \mathrm{O}_{2} 0.05 \%$ (figure 5).

\section{FIGURE 5}

Figure 5: DNA damage quantification by QPCR. A. thaliana WT (Ler) and mutant (tz-201) lines were grown in normal conditions for 18 days. Five hours before harvesting them they were transferred to liquid medium containing 20 g. $\mathrm{L}^{-1}$ of sucrose and hydrogen peroxide in $0.1 \%$ and $0.05 \%$. Errors bars represent the standard deviation between duplicate.

\section{Proteomic analysis}

We performed two-dimensional gel electrophoresis (2D-PAGE) using A. thaliana WT and mutant extracts (quadruplicates) in order to compare protein production in lines expressing THI1 differentially. Staining with Coomassie brilliant blue revealed that only four proteins were differentially expressed in both lines (see squares and arrows in figure 6). All of these proteins were overexpressed in the mutant line, with a difference of, at least, $1.4 \mathrm{x}$, in relation to the WT. 
Spot $a$ showed an increase of $1.5 \mathrm{x}$; spot $b$ and $d$ an increase of $1.4 \mathrm{x}$, and spot $c$ an increase of 2.2x. From these four proteins, two were identified by MALDI-TOF-TOF (figure 6, spots $a$ and $b$; table 1).

Spot $a$ was identified as a phosphoglycerate dehydrogenase (table 1) and spot $b$ as a phosphopyruvate hydratase (enolase) (table 1). Proteins from spots $c$ and $d$ could not be identified.

\section{FIGURE 6}

Figure 6: 2D gel electrophoresis of A. thaliana wild-type (Ler) and mutant (tz-201) proteins grown under normal conditions. Proteins were separated on a 4-7 linear $\mathrm{pH}$ gradient in the first dimension and second dimension in $12 \%$ acrylamide gels and visualized using colloidal Coomassie staining. Black squares and arrows indicate proteins regulated by THI1. Proteins $a$ and $b$ were subsequently identified by MS/MS and is listed in Table 1.

\section{TABLE 1}

Identity of proteins from A. thaliana wild-type (Ler) and mutant (tz-201) lines by MALDI-TOFTOF.

\section{Discussion}

The overexpression and the lower expression of mRNA thil by thi $1_{s} a$ and thi $1_{a s} a$ lines (figure 1A), respectively, do not trigger so much physiologic alterations, since the thi $1_{s} a$ will produces more RNA, while the thil $1_{a s} a$ will produces less RNA, although the protein will be functional, enough to keep the vital function of thi $1_{a s} a$ line. The analysis of THI1 protein production indicated that the primary antibody is binding specifically in THI1 protein since negative control did not show band (figure 1B). Comparing band intensities we could see that mutant and sense lines showed almost half of THI1 quantity of wild-type and antisense lines (figure 1B). Riboswitches are conserved regions of mRNA that bind specific metabolites and regulate gene expression (Thore et al, 2006). It has been described a riboswitch between TPP and mRNA thiC in A. thaliana (Thore et al, 2006) and between TPP and mRNA THIC and THI4 in Chlamydomonas reinhardtii (Croft et al., 2007). Analysis of thil mRNA expression and THI1 
production suggest that thil expression is not regulated by riboswitches. Comparing protein sample band intensities with the positive control, we can deduce that THI1 protein represent about $0.5 \%$ to $1 \%$ of total protein present in extracts of $A$. thaliana (figure 1B). Faou \& Tropschug (2004), concluded that together all isoforms of CyPBP37, THI1 ortholog protein in Neurospora crassa, represent about $1 \%$ to $1.5 \%$ of total cell protein. This high amount of THI shows its functional importance probably because this protein has a short half life being fastly degrated.

Transgenic lines showed higher germination rate than wild-type and mutant lines, the last showing the lowest germination rate (figure 2). These results show that the mutant seeds are less resistent to long period of storage. It is known that during seed quiescence there is progressive degradation of biological molecules, including DNA (Elder et al., 1987). A direct correlation between reduction of seed viability and loss of DNA integrity was established in studies that confirm the increase of chromosomal aberrations and punctual mutations in quiescent seeds (Murata et al., 1982). At the occasion of germination, repair mechanisms are activated so that it is possible for seeds to germinate and originate a plant (Osborne, 1986). Although the exact structure and hydration state of DNA in dried seeds is unknown, one would expect that seeds, when stored for long periods of time in a desiccated state in which no DNA repair occurs, would progressively accumulate AP sites and other spontaneously generated lesions. At some point the amount of damage incurred by aging seeds may exceed the repair capacity of the germinating seedling (Britt, 1996). It is possible that seeds stocked for longer times possess a higher number of lesions, much more than the repair mechanisms can tolerate. This fact is confirmed by studies in which mutant plants deficient in DNA repair produce seeds with lower viability than wild-type plants (Liu et al., 2000; Costa et al., 2001). A factor that contributes to the reduction of seed viability is ROS accumulation (Cardoso, 2004). Considering that there are ROS in normal conditions, they could cause damage in DNA. Mutant line would produce a defective protein, and its absence of functionality would affect the cell metabolism increasing ROS production and, then, decreasing the germination rate of the seedling. The thils a line would produce more THI1 avoiding metabolic imbalance, while the thil $1_{\text {as }} a$ would produce less THI, but enough to avoiding significative metabolic alterations.

Cellular oxygen deficiency is termed hypoxia when oxygen levels limit mitochondrial respiration (Drew, 1997). The responsiveness of sense and antisense plants to hypoxia was 
evaluated, comparatively to wild-type and mutant lines (figure 3). In order to perform this experiment, roots were submerged in liquid medium for 28 days, with medium supply in every week to guarantee the plants were not under nutrients deprivation. We observed a significant difference in survival rates between wild-type and mutant lines, meanwhile sense transgenic plants have a tendency to be more tolerant to flooding stress than wild-type plants mainly in the first 14 days (figure 3B), and antisense lines present an intermediate behavior between mutant and wild-type plants (figures 3A). Expression analysis by qRT-PCR experiment comparing wildtype and mutant line showed higher thil mRNA content in the mutant line submitted to SL condition (figure 4A). Ribeiro et al. (2005), through a series of cassette constructions comprising the thil promoter region fused to GUS reporter gene, observed an increase in expression in roots submitted to hypoxia. The main effect of flooding stress is a reduction of available $\mathrm{O}_{2}$ in the submerged plant part because gases diffuse slower in water than in the air (Dat et al, 2004). At hypoxia conditions the partial pressure of $\mathrm{O}_{2}$ limits ATP production by oxidative phosphorylation. Glycolysis accounts for a larger percentage of ATP yield than under normoxic conditions. Metabolic and developmental changes are stimulated resulting in adaptation to a lowoxygen environment, because to survive short-term flooding plants, as A. thaliana, must generate sufficient ATP, regenerate $\mathrm{NADP}^{+}$and $\mathrm{NAD}^{+}$, and avoid accumulation of toxic metabolites (Bray et al., 2000).

It was also measured the hydrogen peroxide amount and the activity of enzymatic antioxidants in these lines submitted to hypoxia. It was observed an increase in $\mathrm{H}_{2} \mathrm{O}_{2}$ at $\mathrm{SL}$ and SLS conditions in the wild-type and an increase at SLS in the mutant line comparing them to the control (figure 4B). Klok et al (2002) have been described an enhancing ROS formation after flooding stress. According to Blokhina et al (2003), the onset of hypoxia and subsequent reoxygenation is manifested by enhanced ROS formation and lipid peroxidation. Albrecht \& Wiedenroth (1994) showed an increase in oxygen uptake following re-aeration as a response to the high energy demands of the re-activated metabolism. This process is accompanied by fast consumption of previously accumulated sugars and rapid resumption of root elongation (Albrecht et al, 1993). The phenomenon of post hypoxic injury is brought about by generation of ROS and toxic oxidative products such as acetaldehyde (Crawford, 1992). $\mathrm{H}_{2} \mathrm{O}_{2}$ could be produced also as a consequence of the disruption of the mitochondrial electron transport chain (Baxter-Burrell et al, 2002). According to VanToai \& Bolles (1991), conditions favoring the 
formation of ROS, such as low energy charge, high levels of reducing equivalents, and saturated electron transport chains, usually prevail in plant tissues when oxygen supply is restricted. In yeast and mammalian cells, hypoxia stimulates the production of superoxide anion at mitochondrial complex III by increasing the abundance of the partially reduced ubisemiquinone anion (Chandel \& Schumacker, 2000; Semenza, 1999). This reactive anion is fastly converted to $\mathrm{H}_{2} \mathrm{O}_{2}$ by spontaneous dismutation or mitochondrial superoxide dismutase (Fukao et al, 2004).

The lower quantity of $\mathrm{H}_{2} \mathrm{O}_{2}$ in the mutant line grown under hypoxia is coherent with higher CAT activities observed in the mutant line under hypoxia conditions (SL and SLS) including in the control condition in relation to the wild-type (figure 4D). Catalase would detoxify $\mathrm{H}_{2} \mathrm{O}_{2}$ decreasing its amount. We could not observe differences in SOD activities in plants submitted to hypoxia comparing both lines. The function of thiamine biosynthesis is not a limitant factor in this case, since we added vitamin B1 in the liquid medium. VanToai \& Bolles (1991) observed high SOD activity in soybean and suggested that this enzyme would detoxify superoxide radical under reoxigenation conditions. Hydrogen peroxide accumulation and induction of SOD activity under hypoxic conditions have been shown in roots and leaves of Hordeum vulgare (Kalashnikov et al, 1994) and in wheat roots (Biemelt et al, 2000). In rice seedlings, SOD activities responded non-significantly to submergence, while catalase activity increased upon re-admission of oxygen (Ushimaru et al, 1999). Medina-Silva et al (2005) observed an increase of SOD activity in Saccharomyces cerevisiae strain mutant to THI4 gene under control conditions, $30^{\circ} \mathrm{C}$, in relation to the wild-type. The measurements of total SOD indicated that both strains showed significantly increased levels of this activity at $37^{\circ} \mathrm{C}$. Nevertheless, for the thi4 strain, this increase was much more prominent. No differences were detected in CAT activities under any experimental conditions. These data show that the mutant strain, ortholog to thil in S. cerevisiae, overexpress antioxidants even under control conditions in relation to the wild-type, strengthening our data (figure 4D).

In general, it has observed a higher activity of antioxidant enzymes in the mutant line in contrast with the wild-type. The mutant line, which has the defective THI1, could accumulate thiazole precursors. Among these precursors there is the glyceraldehyde 3-phosphate, which participate in photosynthesis and glycolysis, pathways involved in ROS production. This higher ROS production would trigger higher antioxidants production as we could show in this work. Despite antioxidants reduce ROS quantity in the mutant line it was tested if these ROS, produced 
mainly by the electron chain transport, would cause more damage in cloroplast DNA in the mutant line. It was quantified chloroplast DNA damage in wild-type and mutant line after exposition to hydrogen peroxide.

The QPCR (quantitative PCR) is highly sensitive because this methodology permits the quantitative amplification of fragments of genomic DNA between 10 and $25 \mathrm{~kb}$ in length. As a result, very low levels of lesions (approx 1 per $105 \mathrm{~kb}$ ) can be detected, permitting the study of DNA damage and repair at levels of lesions that are biologically relevant. It is possible to use a few nanograms of total genomic DNA, which allows analysis of a much wider range of biological samples than is feasible with other methods, as Southern blot or HPLC, that require 10-50 ug of total cellular DNA. Finally, the use of genomic DNA, which includes nuclear, mitochondrial and chloroplast genomes, allows direct comparison of the degree of damage using the same biological sample. (Santos et al, 2006).

Hydrogen peroxide has been shown to induce a wide variety of damaged bases, several of which may not act as strong blocks to the polymerase. It has been suggested that both of these DNA-damaging agents induce an equal number of single-strand breaks and damaged bases; single-strand breaks are known to be absolute blocks to the polymerase. Hydrogen peroxide has been shown to induce at least 11 different base products, of which $35 \%$ to $50 \%$ of the total adducts are expected to result in strong blocks to the polymerase. Then it is likely that the QPCR assay is detecting a majority of the lesions induced by $\mathrm{H}_{2} \mathrm{O}_{2}$ (Yakes \& Van Houten, 1997).

We have found that $0.1 \% \mathrm{H}_{2} \mathrm{O}_{2}$-induced damages chDNA were higher in the mutant line in relation to the wild-type (figure 5), suggesting that the hydrogen peroxide added to the growth medium plus the endogenous ROS production can increase the susceptability of chloroplast DNA in the mutant line. Probably, the $0.05 \% \mathrm{H}_{2} \mathrm{O}_{2}$ is not so injurious to genomic stability, which could explain similar quantity of lesions in both lines.

Next step in the functional characterization of thil gene was a proteomic analysis comparing wild-type and mutant line. We have found four spots with different expression between the lines studied (figure 6). As showed in table 1, the protein from spot $a$ was identified as phosphoglycerate dehydrogenase and the protein from spot $b$ was identified as phosphopyruvate hydratase (enolase). Both showed more expression in the mutant line comparing with the wild-type.

Phosphoglycerate dehydrogenase (E.C. 1.1.1.95, PGDH) is an enzyme involved in serine 
biosynthesis. Serine biosynthesis in plants proceeds by two pathways: the glycolate pathway (at mitochondria) which is associated with photorespiration and the pathway from 3phosphoglycerate (phosphorylated pathway) which is presumed to take place in the plastids. The 3-phosphoglycerate pathway involves three enzymes catalyzing three sequential reactions: PGDH, 3-phosphoserine aminotransferase (PSAT) and 3-phosphoserine phosphatase (PSP) (Ho \& Saito, 2001). PGDH catalyzes the oxidation of 3-phosphoglycerate (3-PGA) to 3phosphohydroxypyruvate (3-PHP) by utilizing $\mathrm{NAD}^{+}$as a cofactor. Serine is the major source for $\mathrm{C} 1$ metabolism, and glycine is involved in the synthesis of purines. Serine is the precursor of phosphatidylcholine (phospholipid), which has been shown to be involved in adaptative responses to abiotic stresses in plants. Elevated accumulation of serine and glycine has been reported in plants grown at high salinity, or low temperature, or under anaerobic condition (Waditee et al, 2007). Ho \& Saito (2001) observed an increased accumulation of mRNAs involved in the phosphorylation pathway under abiotic stress conditions. Cysteine serves as a precursor for the synthesis of glutathione (GSH), which can works regulating gene expression, controlling cell proliferation, and scavenging ROS (Youssefian et al, 2001). Beside, Hérouart et al (1993) demonstrated that the promoter of cytosolic SOD can be induced by cysteine or GSH. Then, phosphoglycerate dehydrogenase is responsible to serine production, serine to cysteine production, cysteine to GSH production, and the two last compounds still induce SOD promoter.

Phosphopyruvate hydratase (E.C. 4.2.1.11), known also as enolase, converts 2phosphoglycerate to phosphoenolpyruvate in the glycolytic pathway (Lee et al, 2002). In animal cells, part of the enolase protein has been shown to bind to the promoter element of the c-myc gene and to repress c-myc expression (Feo et al, 2000). Enolase can bind to the c-myc promoter as well as to the promoter of the zinc finger STZ/ZAT10 from Arabidopsis, whose expression is induced rapidly and transiently by cold (Lee et al, 2002). LOS2 mutant plants, which produce an inactive enolase, are chilling sensitive and this condition induces cell death (Lee et al, 2002). As described by Lee et al (2002), cell death can be caused by metabolic imbalance because the interruption of enolase activity. A connection between human enolase and programmed cell death has been demonstrated by Ray (1995). The human enolase, MBP-1, when transfected to fibroblasts, induces cell death. Cell death by exogenous MBP-1 does not appear to be due to its direct toxic effect (Ray, 1995). The critical role of myc has been implicated in continuation of proliferation and prevention of programmed cell death. Ray (1995) suggested that when MBP-1 
interacts with $c$-myc there is a decrease in gene transcription, leading to growth arrest and programmed cell death. Considering that the same occurs in plants and that there is an overexpression of enolase in the mutant line, it is possible that occur more programmed cell death in this line in relation to the wild-type. One consequence of programmed cell death is DNA fragmentation. Our QPCR data (figure 5), where we observed more damage in the mutant line, strengthen this hypothesis. Besides, the overexpression of PGDH, leads to more serine and glycine production, being the last involved in purine synthesis, which is coherent with the necessity of genomic material reposition in cells submitted to oxidative stress.

It is known that THI1 protein is involved in thiamine biosynthesis, specifically in the thiazole ring, although there were evidences for a second THI1 function. Godoi et al. (2006) suggested, after searching the THI1 three-dimensional structure over databases, that this protein is homologous to thioredoxin reductase. We tested if THI1 purified was working as thioredoxin and thioredoxin reductase and we could not observed activity to both (data not shown). Results indicate that THI1 maintain cellular homeostase keeping the flux of compounds involved in ROS production.

\section{FIGURE 7}

Figure 7: Schematic representation of metabolic imbalance caused by defective THI1. The defective THI1 protein (1) provokes the accumulation of thiazole precursors, as cysteine and glyceraldehyde 3-phosphate (G3P) (2). The G3P excess would be switched to Calvin cycle to regenerate ribulose 1.5-diphosphate (3). The rubisco can work as oxygenase producing glycolate (4), which is transferred to the peroxisome and is converted in glyoxylate (5). A high G3P availability can increase the glycolysis flux and, consequently, the respiratory rate (6), increasing the ROS production. The phosphoglycerate dehydrogenase is involved in cysteine synthesis (7) which brings about glutathione production. Cysteine and glutathione induce the SOD promoter, increasing antioxidants production (8). Photosynthesis, respiration and photorespiration are pathways involved in ROS production (9), which could cause organelles DNA damage (10) or nuclear DNA (11). The higher amount of ROS triggers a higher antioxidants production (12). The increase of enolase (13), involved in blocking cellular growth and, consequently, taking to 
programmed cell death (14), could explain the delayed development of the mutant line.

\section{Conclusions}

In bacteria, cysteine and glyceraldehyde-3-phosphate (G3P) are thiazole precursors. The G3P excess would be switched to Calvin cycle to regenerate ribulose 1.5-diphosphate. If there is a high G3P amount, the photosynthetic rate will increase, followed by the ROS and antioxidant production, as occurred in the mutant line. A high G3P availability can increase the glycolysis flux and, consequently, the respiratory rate, increasing the ROS production. The phosphoglycerate dehydrogenase, in higher amount in the mutant line, is involved in cysteine synthesis which brings about glutathione production. Cysteine and glutathione induce the SOD promoter, increasing antioxidants production. All these antioxidants are involved in ROS detoxification, in excess in the mutant line. These ROS would decrease seed viability and increase DNA damage. High ROS amount could induce the overexpression of enolase, involved in blocking cellular growth and, consequently, taking to programmed cell death, which could explain the delayed development of the mutant line. Results indicate that defective THI1 bring about metabolic imbalance.

\section{References}

Aebi, H. 1984. Catalase in vitro. Methods in Enzymology 105, 121-130.

Albrecht G, Kammerer S, Praznik W, Wiedenroth EM. 1993. Fructan content of wheat seedlings (Triticum aestivum L.) under hypoxic and following re-aeration. New Phytol. 123, 471-476.

Albrecht G \& Wiedenroth EM. 1994. Protection against activated oxygen following re-aeration of hypoxically pre-treated wheat roots. The response of the glutathione system. J. Exp. Bot. 45, 449-455

Alscher, R. G.; Erturk, N; Heath, L. S. 2002. Role of superoxide dismutases (SODs) in controlling oxidative stress in plants. Journal of Experimental Botany 53 (372), 1331-1341. 
Baxter-Burrell A et al. 2002. RopGAP4-dependent Rop GTPase rheostat control of Arabidopsis oxygen deprivation tolerance. Science 296, 2026-2028.

Belanger C, Leustek T, Chu B, Kriz A. 1995. Evidence for the thiamine pathway in higher plants plastids and its developmental regulation. Plant Molecular Biology 29, 809-821.

Biemelt S, Keetman U, Mock H-P, Grimm B. 2000. Expression and activity of isoenzymes of superoxide dismutase in wheat roots in response to hypoxia and anoxia. Plant Cell and Environment. 23, 135-144.

Blokhina O, Virolainen E, Fagerstedt KV. 2003. Antioxidants, oxidative damage and oxygen deprivation stress: a review. Annals of Botany 91, 179-194.

Bradford MM. 1976. A rapid and sensitive method for the quantitation of microgram quantities of protein utilizing the principle of protein-dye binding. Analytical Biochemistry 72, 248-254.

Bray EA, Bailey-Serres J, Weretilnyk E. Responses to abiotic stresses. In: Buchanan, BB, Gruissem W, Jones, RL.: Biochemistry and Molecular Biology of Plants. Waldorf: Am. Soc. Plant Physiol., 2000. pp. 1158-1203.

Britt, AB. (1996). DNA damage and repair in plants. Annu. Rev. Plant Physiol. Plant Mol. Biol. 47, 75-100.

Cardoso, V. J. M. Germinação. In: Kerbauy, GB.: Fisiologia Vegetal. Rio de Janeiro, Guanabara Koogan, 2004. pp. 386-408.

Chabregas SM, Luche DD, Farias, LP, Ribeiro AF, Van Sluys MA, Menck CFM, Silva-Filho MC. 2001. Dual targeting properties of the N-terminal signal sequence of Arabidopsis thaliana THI1 protein to mitochondria and chloroplasts. Plant and Molecular Biology 46, 639-650.

Chabregas SM, Luche DD, Van Sluys MA, Menck CFM, Silva-Filho MC. 2003. Differential 
usage of two in-frame translational start codons regulates subcellular localization of Arabidopsis thaliana THI1. Journal of Cellular Science 116, 285-291.

Chandel NS, Schumacker PT. 2000. Cellular oxygen sensing by mitochondria: old questions, new insight. J. Appl. Physiol. 88, 1880-1889.

Choi GH, Marek ET, Schardl LC, Richey MG, Chang S, Smith DA. 1990. sti35, a stressresponsive gene in Fusarium spp. Journal of Bacteriology 172, 4522-4528.

Clough SJ, Bent A. 1998. Floral dip: a simplified method for Agrobacterium-mediated transformation of Arabidopsis thaliana. The Plant Journal 16, 735-743.

Costa RM, Morgante PG, Berra CM, Nakabashi M, Bruneau D, Bouchez D, Sweder KS, Van Sluys, MA, Menck CF. 2001. The participation of AtXPB1, the XPB/RAD25 homologue gene from Arabidopsis thaliana, in DNA repair and plant development. The Plant Journal 28, 385395.

Crawford RMM. 1992. Oxygen availability as an ecological limit to plant distribution. Adv. Ecol. Res. 23, 93-185.

Croft MT, Moulin M, Webb ME, Smith AG. 2007. Thiamine biosynthesis in algae is regulated by riboswitches. P.N.A.S. 104 (52), 20770-20775.

Dalton, D. A. Antioxidant defenses of plant and fungi. In: Ahmad, S.: Oxidative Stress and Antioxidant Defenses in Biology. New York, Chapman \& Hall, 1995. pp. 298-355.

Dat JF, Capelli N, Folzer H, Bourgeade P, Badot PM. 2004. Sensing and signalling during plant flooding. Plant Phys. Bioch. 42, 273-282.

Drew MC. 1997. Oxygen deficiency and root metabolism: Injury and acclimation under hypoxia and anoxia. Annu. Rev. Plant Physiol. Plant Mol. Biol. 48: 223-250 
Elder RH, Aquila AD, Mezzina M, Sarasin A, Osborne DJ. 1987. DNA ligase in repair and replication in the embryos of rye, Sacale cereale. Mutation Research 181, 61-71.

Faou P. \& Tropschug M. 2004. Neurospora crassa CyPBP37: a cytosolic stress protein that is able to replace yeast thi4p function in the synthesis of vitamin B1. J. Mol. Biol. 344, 1147-1157.

Feenstra WJ. 1964. Isolation of nutritional mutants in Arabidopsis thaliana. Genetica 35, 259269.

Feo S, Arcuri D, Piddini E, Passantino R, Giallongo A. 2000. ENO1 gene product binds to the cmyc promoter and acts as a transcriptional repressor: relationship with Myc promoter-binding protein 1 (MBP-1). FEBS Lett. 473, 47-52.

Fukao T, Bailey-Serres J. 2004. Plant responses to hypoxia - is survival a balancing act? Trends in plant science $9(9), 449-456$.

Godoi PHC, Galhardo RS, Luche DD, Van Sluys MA, Menck CFM, Oliva G. 2006. Structure of the thiazole biosynthetic enzyme THI1 from Arabidopsis thaliana. JBC. 281 (41), 30957-66.

Gynheung A, Ebert PR, Mitra A, Ha SB. 1989. Binary vectors. In: SB Gelvin, PA Schilperrort, DPS Verma (eds), Plant Gene Research Manual. Martinus Nijhoff Publisher, 1-27.

Halliwell B \& Gutterridge JMC. Free Radicals in Biology and Medicine. 3.a ed. United States, Oxford Science Publications, 1999. 936 pp.

Hérouart D, Van Montagu M, Inze D. (1993). Redox-activated expression of the cytosolic copper / zinc superoxide dismutase gene in Nicotiana. Proc. Natl. Acad. Sci. USA 90. 31083112.

Ho CL \& Saito K. (2001). Molecular biology of the plastidic phosphorylated serine biosynthetic 
pathway in Arabidopsis thaliana. Amino Acids 20, 243-259.

Jacob-Wilk D, Golschmidt EE, Riov J, Sadka A, Holland D. 1997. Inductions of a Citrus gene highly homologous to plant and yeast thi genes involved in thiamine biosynthesis during natural and ethylene induced plant maturation. Plant Molecular Biology 35, 661-666.

Jurgenson CT, Chatterjee A, Begley TP, Ealick SE. 2006. Structural insights into the function of the thiamin biosynthetic enzyme Thi4 from Saccharomyces cerevisiae. Biochemistry 45, 1106111070.

Kalashnikov JuE, Balakhnina TI, Zakrzhevsky DA. 1994. Effect of soil hypoxia an activation of oxygen and the system of protection from oxidative destruction in roots and leaves of Hordeum vulgare. Russian Journal of Plant Physiology. 41, 583-588.

Kimura S \& Sakaguchi K (2006). DNA repair in plants. Chem. Rev. 106, 753-766.

Klok EJ, Wilson IW, Wilson D, Chapman SC, Ewing RM, Somerville SC, Peacock WJ, Dolferus R, Dennis ES. 2002. Expression profile analysis of the low-oxygen response in Arabidopsis root cultures. Plant Cell 14, 2481-2494.

Lee H, Guo Y, Ohta M, Xiong L, Stevenson B, Zhu JK. (2002). LOS2, a genetic locus required for cold-responsive gene transcription encodes a bi-functional enolase. The EMBO Journal 21 (11), 2692-2702.

Liu Z, Hossain GS, Islãs-Osuna MA, Mitchell DL, Mount DW. 2000. Repair of UV damage in plants by nucleotide excision repair: Arabidopsis UVH1 DNA repair gene is a homolog of Saccharomyces cerevisiae Rad1. The Plant Journal 21, 519-528.

Machado CR, Costa de Oliveira R, Boiteux S, Praekelt UM, Meacock PA, Menck CFM. 1996. thil, a thiamine biosynthetic gene in Arabidopsis thaliana, complements bacterial defects in DNA repair. Plant Molecular Biology 31, 585-593. 
Machado CR, Praekelt UM, Costa de Oliveira R, Barbosa AC, Byrne KL, Meacock PA, Menck CFM. 1997. Dual role for the yeast THI4 gene in thiamine biosynthesis and DNA damage tolerance. Journal of Molecular Biology 273, 114-121.

Manetti AGO, Rosetto M, Maundrell KG.1994. nmt2 of fission yeast: a second thiaminerepressible gene co-ordinately regulated with $n m t 1$. Yeast 10, 1075-1082.

McCord JM, Fridovich I. 1969. Superoxide Dismutase, an enzymic function for erythrocuprein (hemocuprein). The Journal of Biological Chemistry 244 (22), 6049-6055.

Medina-Silva R, Barros MP, Galhardo RS, Netto LES, Colepicolo P, Menck CFM. (2006). Heat stress promotes mitochondrial instability and oxidative responses in yeast deficient in thiazole biosynthesis. Research in Microbiology. 157(3), 275-81.

Mittler R. 2002. Oxidative stress, antioxidants and stress tolerance. Trends in Plant Science 7(9), 405-410.

Murata M, Tsuchiya T, Roos EE. 1982. Chromosome damage induced by artificial seed aging in barley: II. Types of chromosomal aberrations at first mitosis. Bot. Gaz 143, 111-116.

Neuhoff V, Arold N, Taube D, Ehrhardt W. 1988. Improved staining od proteins in polyacrylamide gels including isoelectric focusing gels with clear background at nanogram sensitivity using Coomassie Brilliant Blue G-250 and R-250. Electrophoresis. 9(6), 255-262.

Osborne DJ. 1986. Senescence in seeds. In: Kenneth V. Thimann (ed.). Senescence in plants, $3^{\text {rd }}$ ed. Boca Raton: CRC Press Inc, 13-37.

Papini-Terzi FS, Galhardo RS, Farias LP, Menck CFM, Van Sluys MA. 2003. Point mutation is responsible for Arabidopsis tz-201 mutant phenotype affecting thiamine biosynthesis. Plant Cell Physiology 44, 856-860. 
Polle A. (2001). Dissecting the superoxide dismutase - ascorbate peroxidase - glutathione pathway in chloroplasts by metabolic modeling. Computer simulations as a step towards flux analysis. Plant Physiol. 126, 445-462.

Praekelt UM, Byrne KL, Meacock PA. 1994. Regulation of THI4 (MOL1), a thiaminebiosynthetic gene of Saccharomyces cerevisae. Yeast 10, 481-490.

Punchard, N. A. \& Kelly, F. J. - Introduction. In: Punchard, N. A. \& Kelly, F. J. - Free Radicals, A practical approach. United States, Rickwood \& Hames, 1996. pp. 1-8.

Rao, M. V.; Paliyath, G.; Ormrod, D. P. 1996. Ultraviolet-B-and ozone-induced Biochemical changes in antioxidant enzymes of Arabidopsis thaliana. Plant Physiol. 110, 125-136.

Ray RB. (1995). Induction of cell death in murine fibroblasts by a c-myc promoter binding protein. Cell Growth \& Differentiation 6, 1089-1096.

Ribeiro A, Praekelt UM, Akkermans ADL, Meacock PA, Van Kammen A, Bisseling T, Pawlowski K. 1996. Identification of agthil, whose product is involved in biosynthesis of the thiamine precursor thiazole in actinorhizal nodules of Alnus glutinosa. The Plant Journal 10, 361-368.

Ribeiro DT, Farias LP, Almeida JD, Kashiwabara PM, Ribeiro AFC, Silva-Filho MC, Menck, CFM, Van Sluys MA. 2005. Functional characterization of the thil promoter region from Arabidopsis thaliana. Journal of Experimental Botany 56 (417), 1797-1804.

Santos JH, Mandavilli BS, Van Houten B. 2002. Measuring oxidative mtDNA damage and repair using quantitative PCR. Methods in Molecular Biology 197, 159-176.

Semenza GL. 1999. Perspectives on oxygen sensing. Cell 98, 281-284. 
Sohn J, Voegele RT, Mendgen K, Hahb M. 2000. High level activation of vitamin B1 biosynthesis genes in haustoria of the rust fungus Uromyces fabae. Molecular Plant- Microbe Interaction 13,629-636.

Sun W, Gao S, Wang L, Chen Y, Wu S, Wang X. 2006. Microwave-assisted protein preparation and enzymatic digestion in proteomics. Molecular and cellular proteomics. 5, 769-776.

Thore S, Leibundgut M, Ban N. 2006. Structure of the eucaryotic thiamine pyrophosphate riboswitch with its regulatory ligand. Science 312, 1208-1211.

Ushimaru T, Kanematsu S, Shibasaka M, Tsuji H. (1999). Effect of hypoxia on the antioxidative enzymes in aerobically grown rice (Oryza sativa) seedlings. Physiologia Plantarum. 107, 181187.

Van Gestelen P, Ledeganck P, Wynant I, Caubergs RJ, Asard H. 1998. The cantharidin-induced oxidative burst in tobacco BY-2 cell suspension cultures. Protoplasma. 205, 83-92.

Van Sluys MA, Alcantara-Gomes R, Menck CE. (1986). Escherichia coli xthA mutant is not hypersensitive to ascorbic acid/copper treatment - an $\mathrm{H}_{2} \mathrm{O}_{2}$ generating reaction. Mutat. Res. 174(4), 265-269.

VanToai TT, Bolles CS. 1991. Postanoxic injury in soybean (Glycine max) seedlings. Plant Physiol. 97, 588-592.

Waditee R, Bhuiyan NH, Hirata E, Hibino T, Tanaka Y, Shikata M, Takabe T. (2007). Metabolic Engineering for betaine accumulation in microbes and plants. The Journal of Biological Chemistry. 282 (47), 34185-34193.

Wang W, Vignani R, Scali M, Cresti M. 2006. A universal and rapid protocol for protein extraction from recalcitrant plant tissues for proteomic analysis. Electrophoresis. 27, 2782-2786. 
Yakes FM \& Van Houten B. 1997. Mitochondrial DNA damage is more extensive and persists longer than nuclear DNA damage in human cells following oxidative stress. Proc. Natl. Acad. Sci. USA. 94, 514-519.

Youssefian S, Nakamura M, Orudgev E, Kondo N. (2001). Increased cysteine biosynthesis capacity of transgenic tobacco overexpressing an O-acetilserine(thiol) lyase modifies plant responses to oxidative stress. Plant Physiology 126, 1001-1011.

\section{Acknowledgments}

This work was supported by Fundação de Amparo à Pesquisa do Estado de São Paulo (FAPESP, São Paulo, Brazil) and PADCT/CNPq (Brasília, Brazil). We are grateful to the PhD Luis Eduardo Soares Netto for lending us reagents for the enzyme activity experiments. M.M.M was recipient of a FAPESP fellowship. 


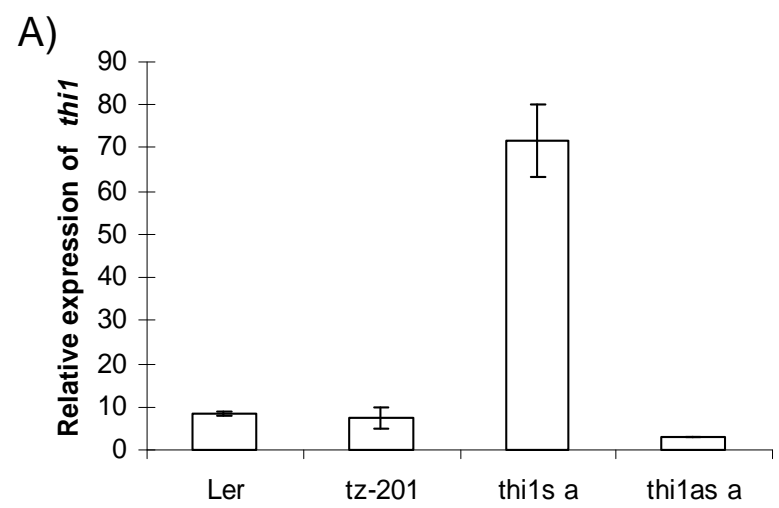

B) $0,01 \mathrm{ug} \quad 0,01 \mathrm{ug} 1 \mathrm{ug} \quad 1 \mathrm{ug} \quad 1 \mathrm{ug} \quad 1 \mathrm{ug}$

\begin{tabular}{ccccc}
- & thi1 & Ler & tz-201 thi1s thi1as \\
\hline & $\mid$ & $\mid$ & $\mid$
\end{tabular}

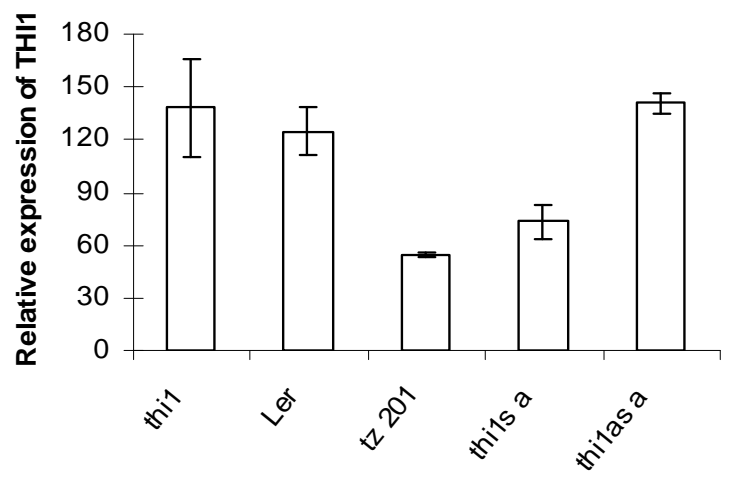

Figure 1 


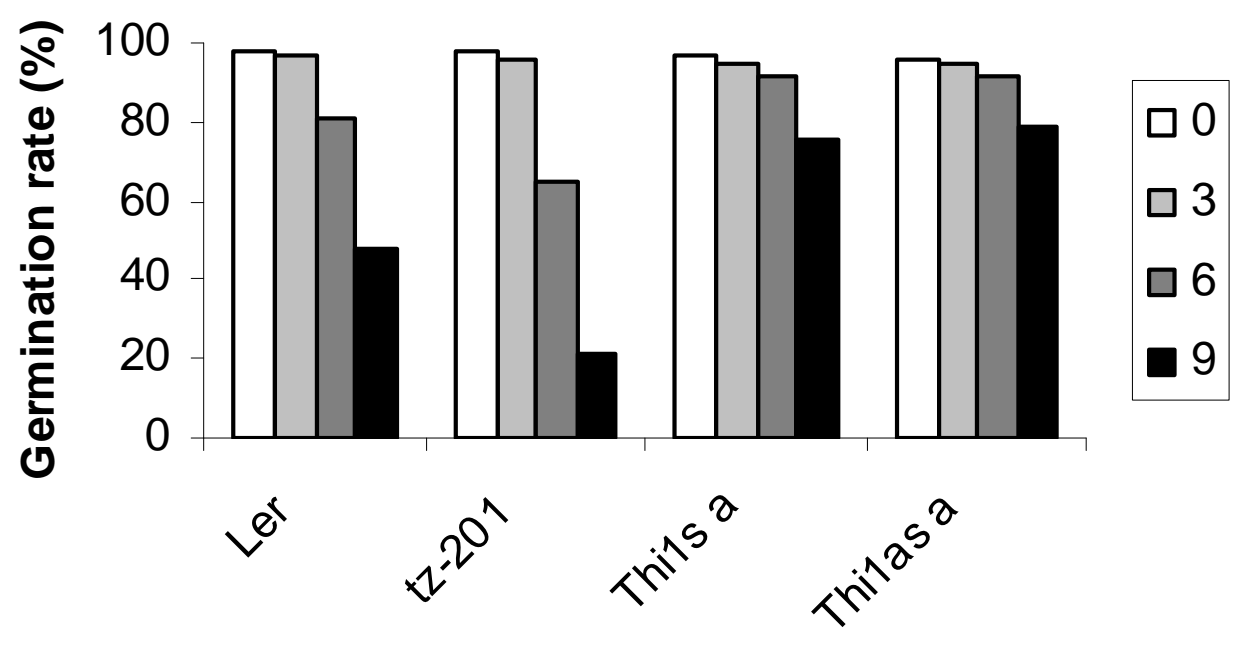

Figure 2 
A)

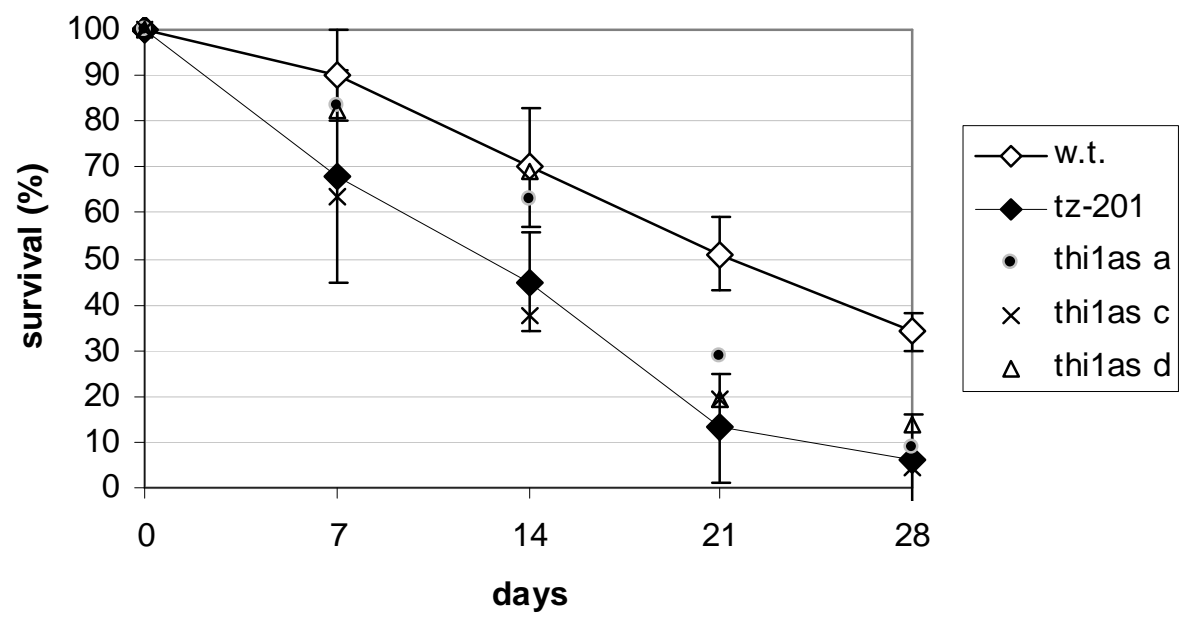

B)

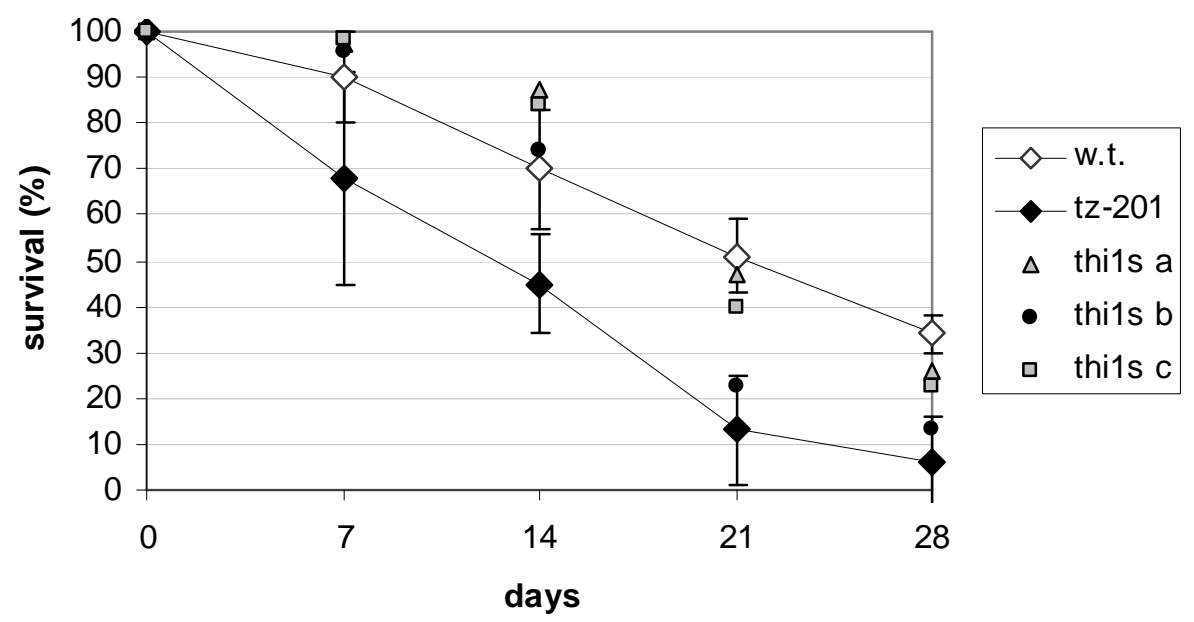

Figure 3 

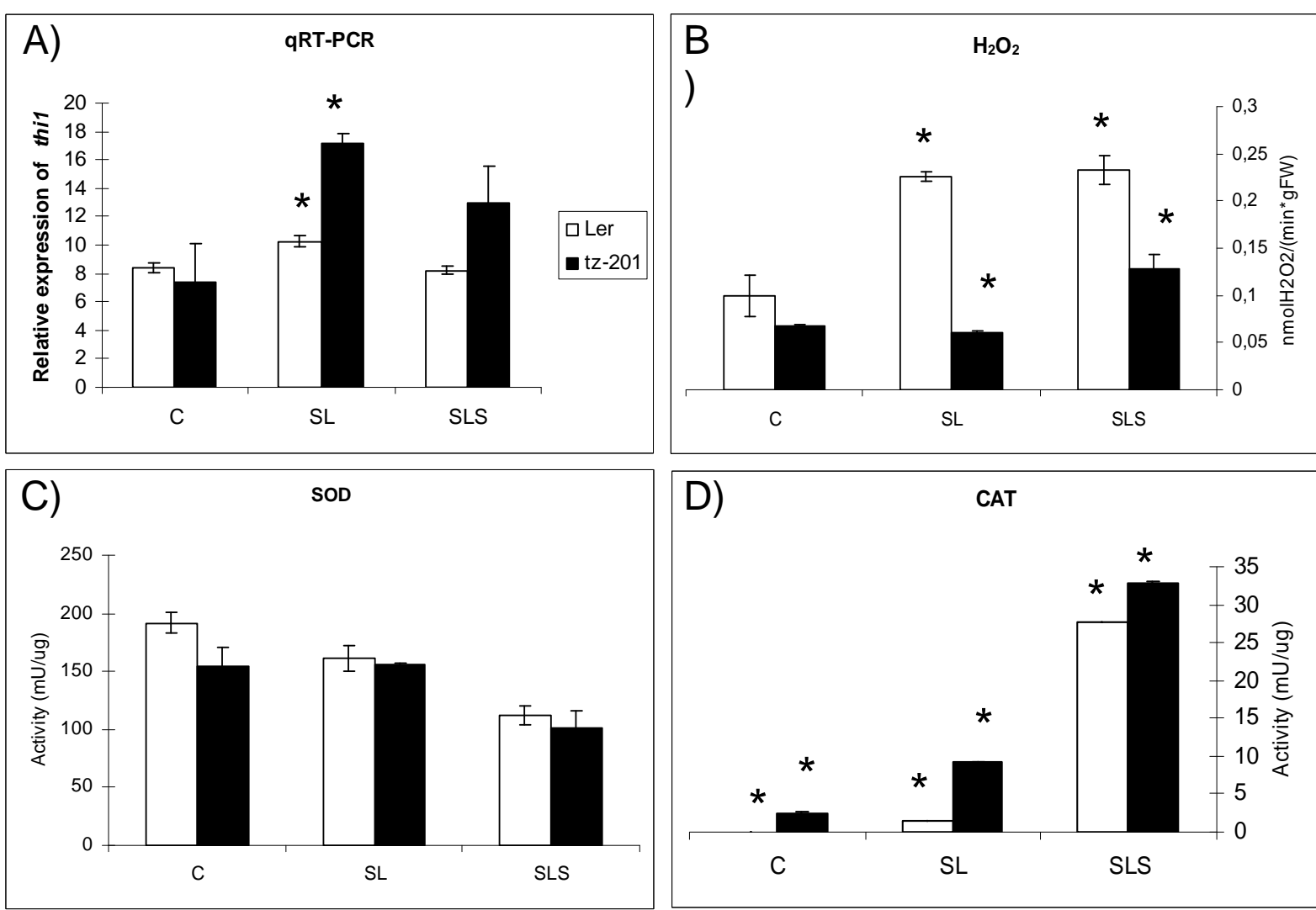

D)

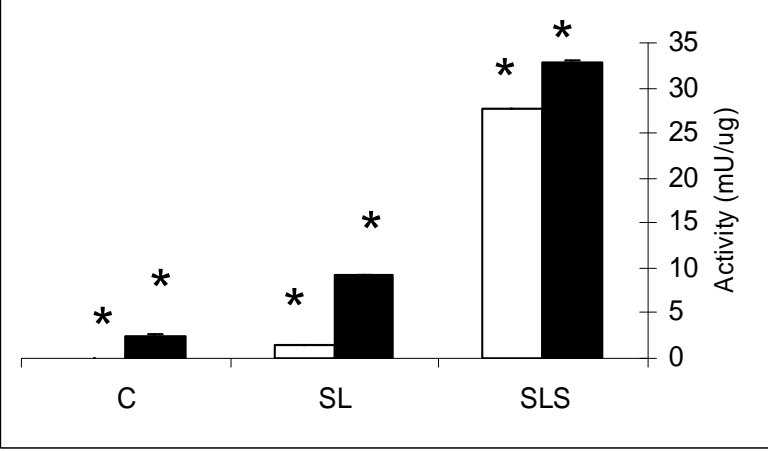

Figure 4 


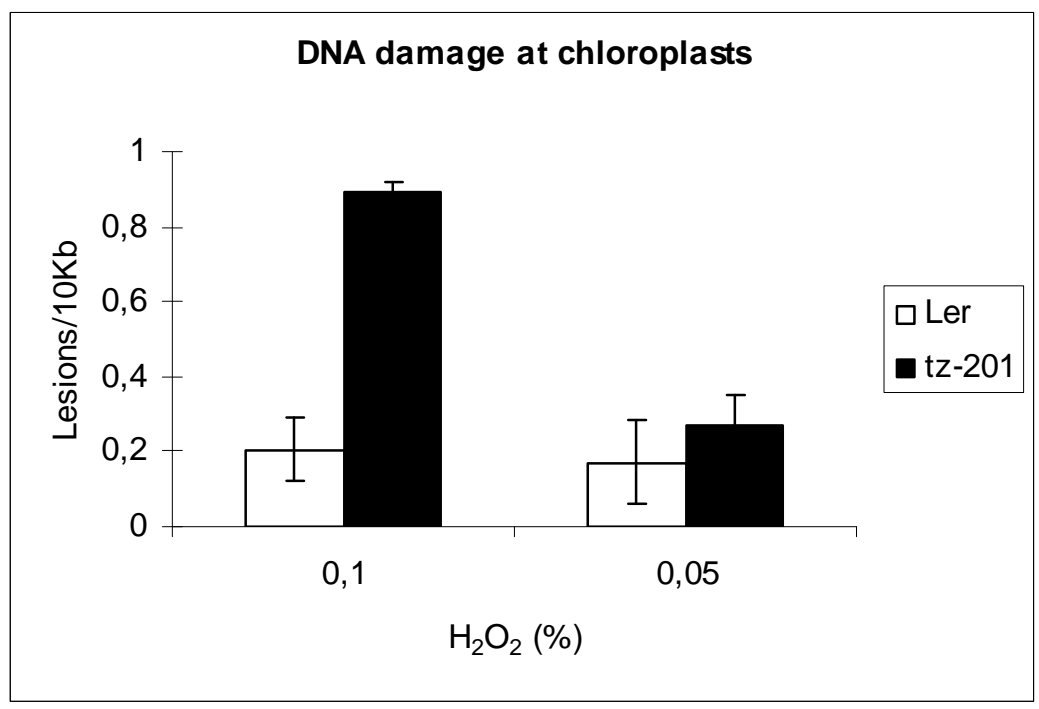

Figure 5 


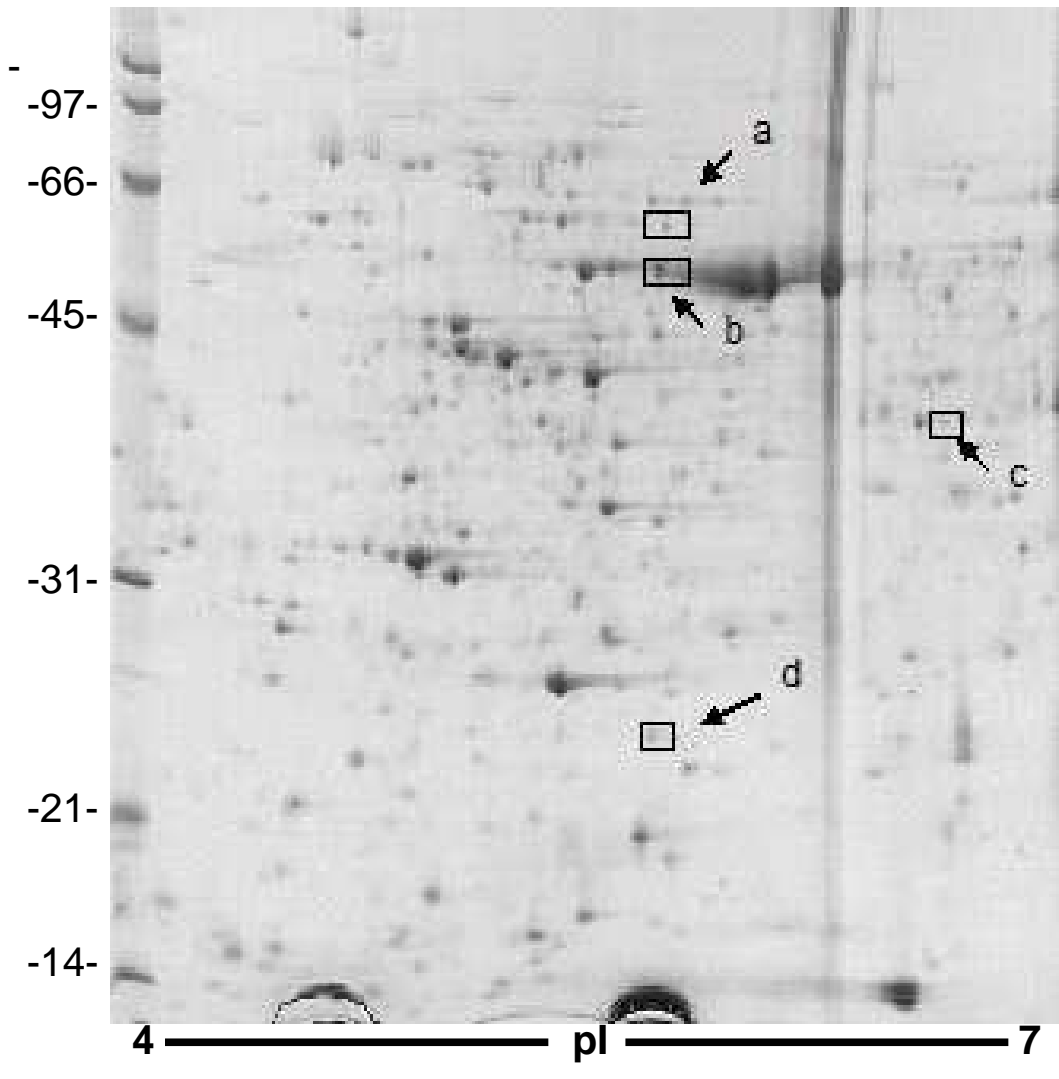

Figure 6 


\section{Mutant}

(tz-201)

Defective THI1

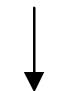

Accumulation of thiazole

precursors
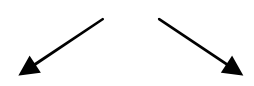

Cysteíne

Glyceraldehyde

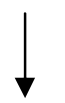

3-phosphate

\section{Overexpression of phosphoglycerate \\ dehydrogenase}

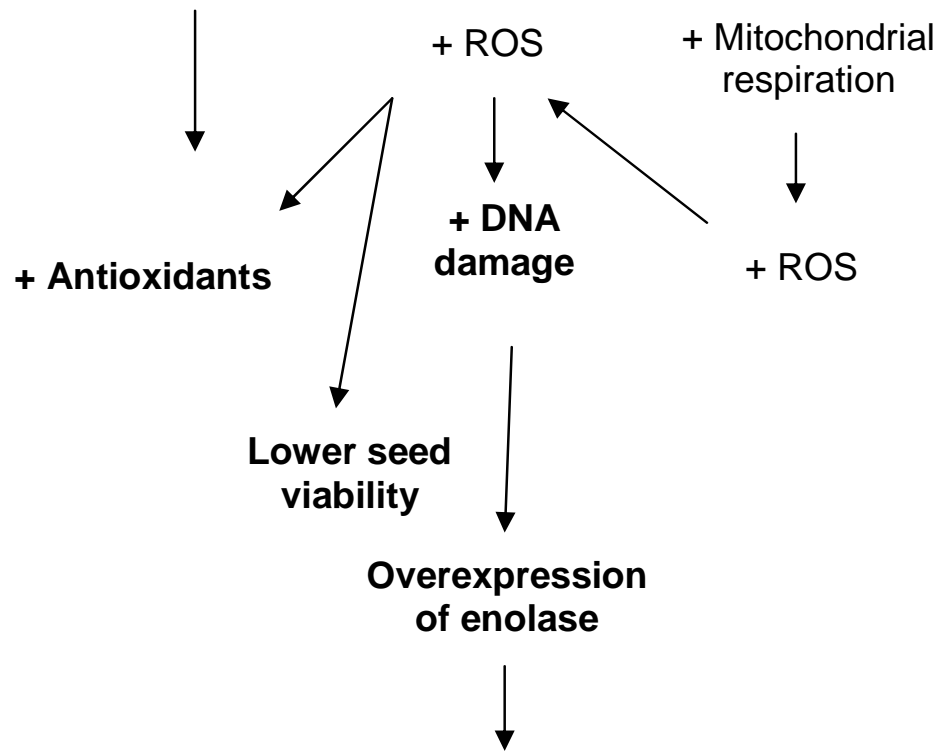

Cell growth arrest

Figure 7

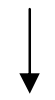

Apoptosis

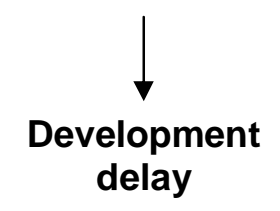




\begin{tabular}{|c|c|c|c|c|c|c|}
\hline Spot & Protein & $\begin{array}{c}\text { Accession } \\
\text { number }\end{array}$ & $\begin{array}{c}\text { Pre } \\
\text { pI }\end{array}$ & $\begin{array}{c}\text { Pre } \\
\text { Massa } \\
\text { (kDa) }\end{array}$ & $\begin{array}{l}\text { Protein } \\
\text { score }\end{array}$ & $\begin{array}{c}\text { Sequence of identified } \\
\text { peptides }\end{array}$ \\
\hline $\mathrm{a}$ & $\begin{array}{l}\text { Phosphoglycerate dehidrogenase } \\
\text { (Arabidopsis thaliana) }\end{array}$ & $\frac{\text { gi| } 15235282}{(\mathrm{AT} 4 \mathrm{G} 34200}$ & $\begin{array}{c}6,1 \\
6\end{array}$ & 63286 & 150 & $\begin{array}{l}\text { ILNDETFAK } \\
\text { GGVIDEDALVR } \\
\text { VIAHDPYAPADR } \\
\text { VGREVFESSHGR }\end{array}$ \\
\hline $\mathrm{b}$ & $\begin{array}{c}\text { Phosphopyruvate hidratase } \\
\text { (enolase) } \\
\text { (Arabidopsis thaliana) }\end{array}$ & $\frac{\text { gi| } 15227987}{(\text { AT2G36530) }}$ & $\begin{array}{c}5,4 \\
5\end{array}$ & 47747 & 154 & $\begin{array}{l}\text { HIANLAGNPK } \\
\text { AGWGVMTSHR } \\
\text { AGWGVMTSHR+Oxidat } \\
\text { ion (HW) } \\
\text { MGVEVYHHLK } \\
\text { KAGWGVMTSHR } \\
\text { KAGWGVMTSHR+Oxid } \\
\text { ation (HW) }\end{array}$ \\
\hline $\mathrm{c}$ & n.d. & - & - & - & - & - \\
\hline $\mathrm{d}$ & n.d. & - & - & - & - & - \\
\hline
\end{tabular}

Predict (Pre) pl and mass are shown. Spot $c$ and $d$ were not determined (n.d.)

\section{Table 1}

